\title{
Indian Islamic Architecture
}




\title{
Handbook of Oriental Studies \\ Handbuch der Orientalistik
}

\author{
Section Two \\ India \\ Edited by \\ J. Bronkhorst
}

VOLUME 20 


\section{Indian Islamic Architecture}

Forms and Typologies, Sites and Monuments

$$
\text { By }
$$

John Burton-Page $\dagger$

Edited by

George Michell

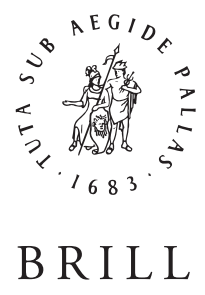

LEIDEN • BOSTON

2008 


\section{B RILL OPE N}

This is an open access title distributed under the terms of the prevailing CC-BY-NC License at the time of publication, which permits any non-commercial use, distribution, and reproduction in any medium, provided the original author(s) and source are credited.

III An electronic version of this book is freely available, thanks to the support of libraries working with Knowledge Unlatched (KU). $\mathrm{KU}$ is a collaborative initiative designed to make high quality content Open Access for the public good. More information about the initiative and links to the Open Access version can be found at www.knowledgeunlatched.org.

On the cover: Multan, tomb of Rukn-i 'Ālam, mid 14th century (courtesy George Michell)

This book is printed on acid-free paper.

\section{Library of Congress Cataloging-in-Publication Data}

A C.I.P. record for this book is available from the Library of Congress.

ISSN 0169-9377

ISBN 9789004163393

Copyright 2008 by Koninklijke Brill NV, Leiden, The Netherlands.

Koninklijke Brill NV incorporates the imprints Brill, Hotei Publishing, IDC Publishers, Martinus Nijhoff Publishers and VSP.

All rights reserved. No part of this publication may be reproduced, translated, stored in a retrieval system, or transmitted in any form or by any means, electronic, mechanical, photocopying, recording or otherwise, without prior written permission from the publisher.

Authorization to photocopy items for internal or personal use is granted by Koninklijke Brill NV provided that the appropriate fees are paid directly to The Copyright Clearance Center, 222 Rosewood Drive, Suite 910, Danvers, MA 01923, USA.

Fees are subject to change.

PRINTED IN THE NETHERLANDS 


\section{GONTENTS}

Editorial Note and Acknowledgements …………..................... vii

John Burton-Page: An Introduction, George Michell …........... ix

John Burton-Page: Bibliography ………………..................... xvii

INTRODUCTION

Sultanate Architecture ...........................................................

Mughal Architecture ......................................................... 27

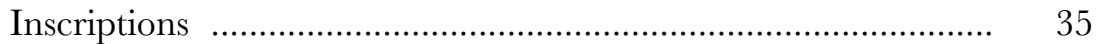

\section{PORTFOLIO OF PHOTOGRAPHS}

Forms AND TyPOLOGIES

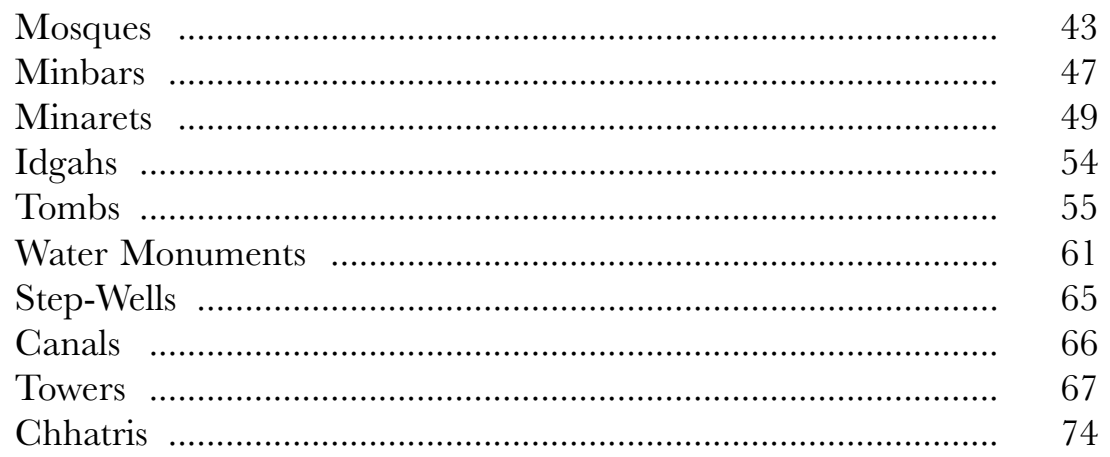

\section{Sites AND Monuments}

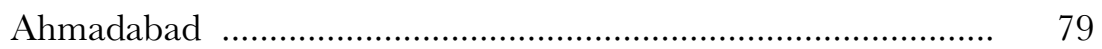

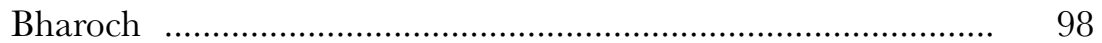

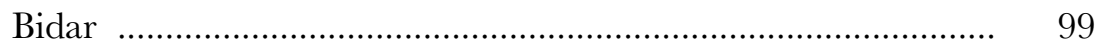

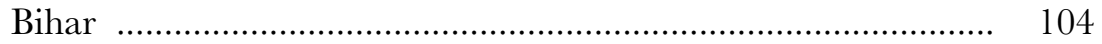

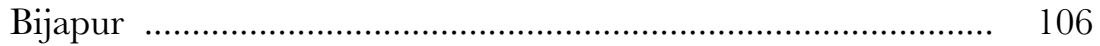


Champaner …................................................................. 111

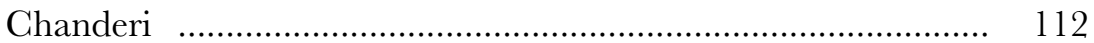

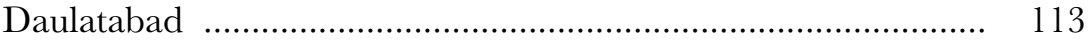

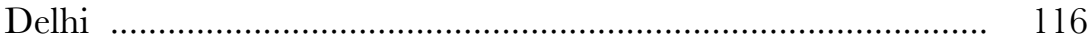

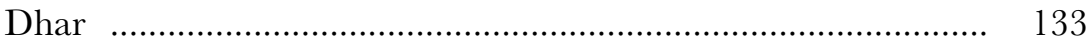

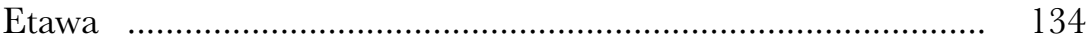

Gawilgarh ................................................................... 136

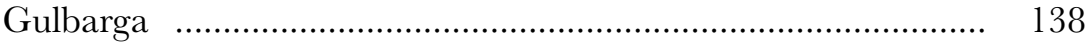

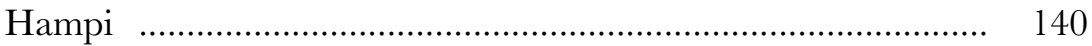

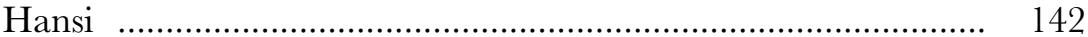

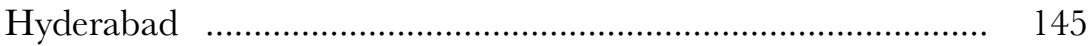

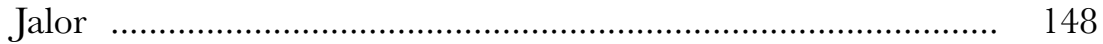

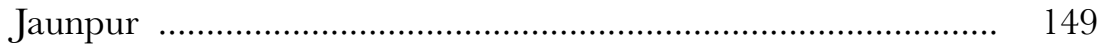

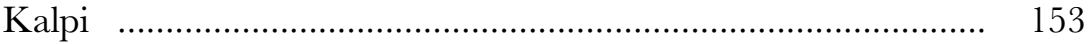

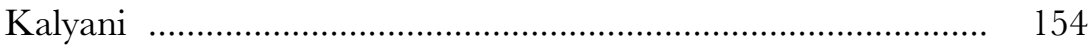

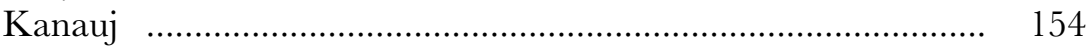

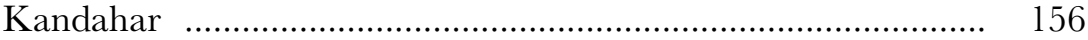

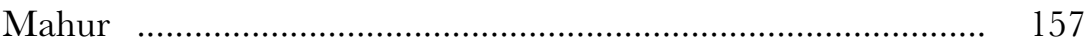

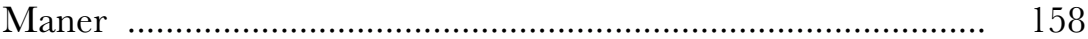

Mathura ……............................................................. 160

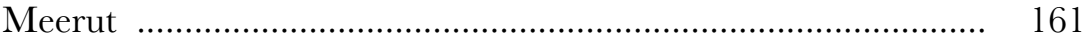

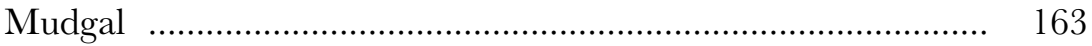

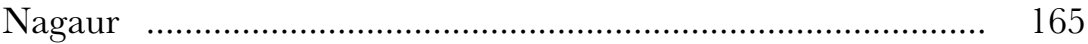

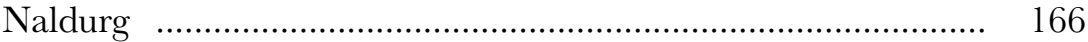

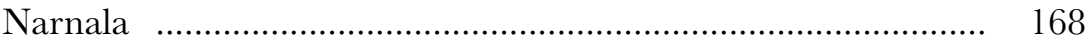

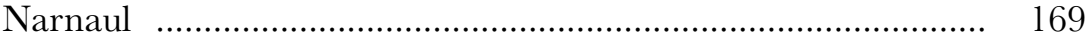

Thalner ……................................................................. 170

\section{Dogumentation}

Glossary of Indian Architectural Terms .................................. 179

Abbreviations of Journals and Monographic Series ……......... 183

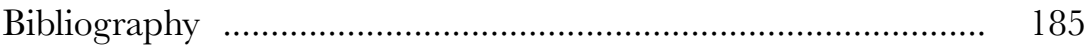

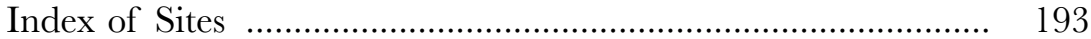




\section{EDITORIAL NOTE AND AGKNOWLEDGEMENTS}

With two exceptions, all the articles of John Burton-Page in this volume are reproduced from the 2nd Edition of Encyclopaedia of Islam (EI; volume and page numbers indicated for each entry). The spellings have been slightly amended to accord with common Indian usage, especially for place names. Hijra and Christian Era dates, and diacritical marks for names and terms, have been retained as in the original entries.

Most of Burton-Page's contributions to EI were supplied with bibliographies of varying lengths, but there was inevitably considerable overlap. A composite bibliography has been compiled for this volume, covering all regions and sites, to which the editor has added a few recent works of importance (indicated by an asterisk), published after Burton-Page authored his articles. A list of abbreviations is appended. Architectural terms used in the various entries are explained in a glossary.

Only a few of Burton-Page's the articles were illustrated in EI, but the editor decided to include here a selection of black and white photographs. Most of these come from the archives of the American Institute of Indian Studies in Delhi. Other photographs were supplied by a number of individuals who are credited in the photographic list. Unfortunately it was not possible to add maps and architectural plans, elevations and details for the various sites, but the availability of such data may be traced to the relevant bibliographic entries.

The editor is grateful to Marg Publications in Mumbai for permission to reproduce Burton-Page's article on Ahmadabad, and also for allowing reproduction of photographs of two monuments in Kashmir.

Throughout his work on the volume the editor has been much encouraged by Piers Burton-Page, eldest son of John Burton-Page. At Brills, Patricia Radder has overseen the project with enthusiasm and attention to detail.

The author would like to express his thanks to all these individuals and institutions.

George Michell 


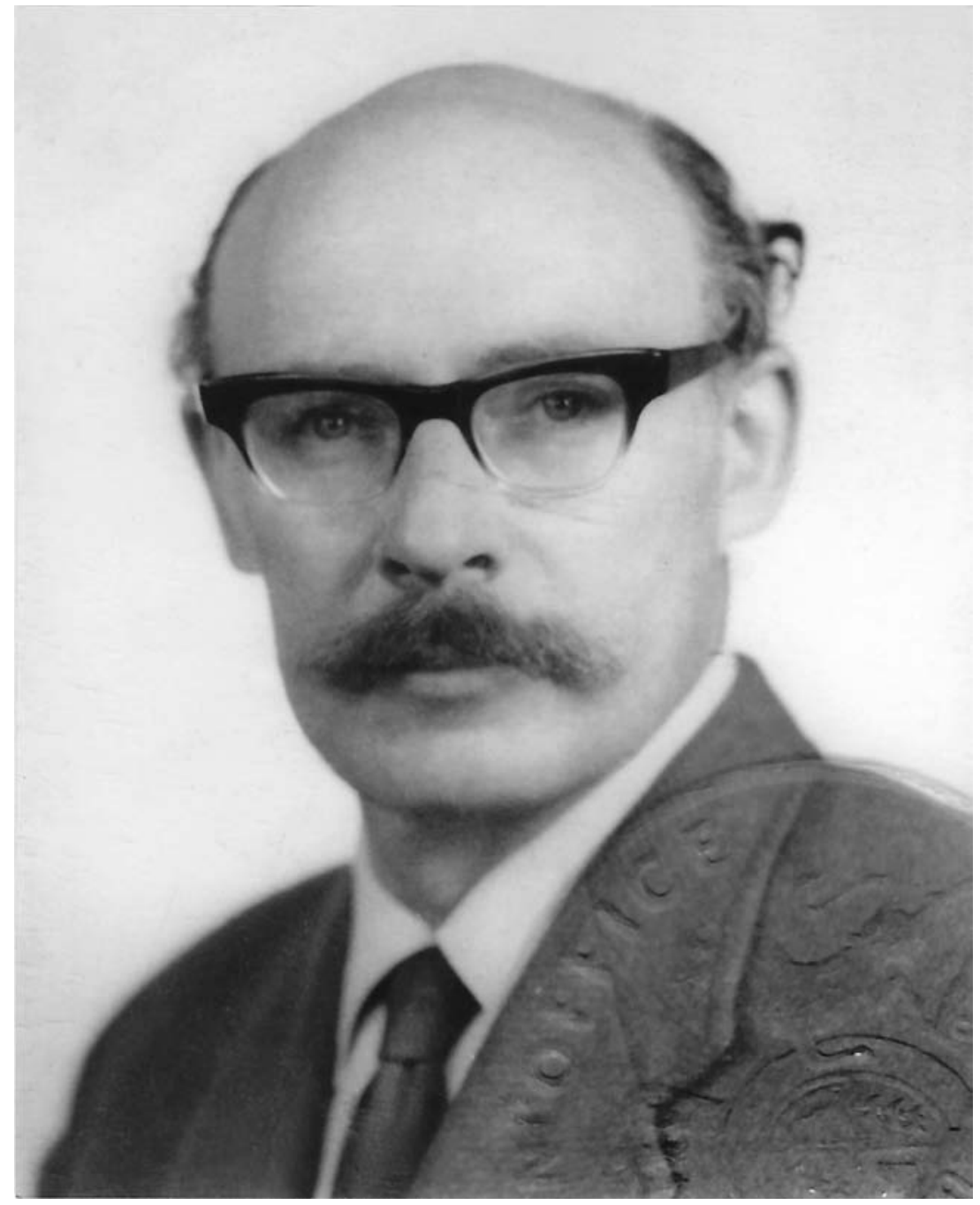

John Burton-Page 1921-2005 


\title{
JOHN BURTON-PAGE: AN INTRODUGTION
}

\author{
George Michell
}

There is nothing in the early life of John Garrard Burton-Page to give a hint of his later fascination with India. Born in London on 19th December 1921, John was initially tempted to study medicine, but already as a teenager developed a passion for Western Classical music. In 1939 he enrolled at the Royal College of Music, London, as a horn player, where his fellow student was Dennis Brain, destined to become the finest English horn player of the post-World War II period. At the end of a single successful term of musical studies John was called up for military service, and after officer training was sent to India, where he experienced the "hidden war" in Burma, ending up in 1945 as Captain in the 1st King George V's Own Gurkha Rifles. It was in India that John discovered both an attraction and aptitude for Oriental languages, becoming fluent in Hindi and Nepali, and partly in Urdu, within only a few years. At the same time he developed what was to become a lifelong curiosity in the land, peoples and architecture of India. Acting on this newly found interest, John return to England and instead of returning to his musical career decided to study Sanskrit. On his demobilization in 1946 he matriculated and was accepted as a mature student in Sanskrit at Wadham College, Oxford. He graduated in 1950 with a degree in Oriental Languages and a half-blue for fencing, as well as a wife, Audrey, and two small sons, Piers and Nicholas. John then went straight to the School of Oriental and African Studies (S.O.A.S.) at the University of London, where he was to remain for more than 30 years. He began his career there as Temporary Lecturer in Nepali, and subsequently held appointments as Lecturer and Reader in Hindi. He also held the position there in 1968-72 of Chairman of the newly formed Centre of South Asian Studies. Gradually John's interest in Muslim culture prevailed, and he started to research and write on different aspects of Indo-Islamic history and architecture. He took leave of absence in 1958-9 to spend year in India together with his family, now augmented to three sons. From his base at the Deccan College of Postgraduate Studies in Poona he, Audrey and the three boys made frequent visits to various Buddhist, Hindu and Muslim sites. 
After the retirement in 1966 of K. de B. Codrington, Professor of Indian Archaeology at S.O.A.S. since 1948, John assumed responsibility for teaching the subject, but only in 1971 was he confirmed as Reader in the Art and Archaeology of South Asia. The new position permitted John to better concentrate on his art historical pursuits and to make further study trips to India, where he investigated both familiar and unfamiliar monuments at Sultanate and Mughal sites. John was an indefatigable and capable photographer, and his archives, now deposited at S.O.A.S., are among the most extensive ever compiled on the subject. Encouraging the company of fellow travellers, he invited research students along, regaling them with impromptu talks in front of mosques and shrines. He also occasionally accompanied British and American tourists for Swans Hellenic, one of the first companies to offer 'art treasure' tours of India. John always assumed a friendly and welcoming approach to the academic life, attempting whenever possible to forge a link between staff and students. In the early 1970s he was instrumental in founding the Daniells' Society. Named after the celebrated uncle and nephew team of artists that travelled the length and breadth of India in the last decade of the eighteenth century, this Society met every few months at the London homes of teachers and research students at S.O.A.S., where informal slide shows and dinners were enjoyed by all. On some of these occasions John displayed his considerable culinary skills by preparing superb Indian banquets. These reflected yet another of the Subcontinent's cultural delights that he had expertly trained himself in. A further activity during these years was involvement with the Royal Asiatic Society. John served as Director of the Society in 1968-71, and continued as one of the Vice Presidents up until 1975, as well as assisting on the editorial board of the Society's prestigious journal.

By the time John retired from S.O.A.S. at the end of March 1982 he and Audrey had moved out of London to Church Knowle, a peaceful village in the rolling landscape of Purbeck, in Dorset. There he enjoyed researching and writing, tending to his garden, doing the Times crosswords, listening to records, and cooking splendid Indian meals with which to treat guests - but abandoning them whenever cricket test matches were relayed on television! After Audrey's unexpected early death in 1989 John continued to live in Dorset, with intermittent research trips to India, but he never truly recovered from the blow. In 1994 he suffered a stroke and was confined to a local nursing home where, sadly, he was not well enough to continue working. There 
almost eleven years later he died on 13th June 2005, and a few days later was buried next to Audrey in the lovely hillside cemetery above Church Knowle.

How exactly John made the seemingly arbitrary transition from the world of European Classical music to Indian languages, and then to Indo-Islamic architecture, must remain something of a mystery. He never discussed it and perhaps never reflected upon it, but merely pursued the different trajectories of his interests with natural facility and unbridled enthusiasm. Nonetheless, he maintained a love of music throughout his life, sometimes even managing to bridge the gap between European music and India architecture, as in his final appraisal of the Taj Mahal in Agra: "I have heard it described as having a Mozartean grace - but for me it is too predictable ever to approach the Mozartean heights; I would settle for Boccherini." John instilled in all three sons a profound appreciation for music. Nicholas, the middle son, fulfilled his father's original ambition by graduating in horn from the Royal College of Music, and then going on to become a specialist in Baroque music, teaching at the Conservatorium at Aubervilliers outside Paris. The eldest son, Piers, enjoyed a public career as a radio announcer and programmer on Radio 3, the Classical music station of the B.B.C., while Tony, the youngest, was responsible for music among other subjects at a boys' school in Dorset, composing choral settings for the choir and musicals for staff and pupils alike.

Likewise, John never gave up his interest in Indian languages and the finer points of linguistics. His first articles, published in Bulletin of the School of Oriental and African Studies (hereafter BSOAS) and Bulletin of the Deccan College, teased out some of the problematics of Nepali and Hindi, while some of his contributions to Encyclopaedia of Islam (hereafter EI) focused on the development of Hindi at the Mughal court, and the use of various letters of the Arabic alphabet in Urdu, Sindhi and other South Asian languages. But it was a love of Indo-Muslim history, culture and particularly architecture that ultimately won through. In this regard John was much encouraged by Sir Mortimer Wheeler, whom he probably first met when Wheeler was Director General of Archaeology for the Government of India in 1944-47. John contributed six chapters on Islamic monuments in India and Pakistan for an illustrated book edited by Wheeler that appeared in 1965. Thereafter, it was this subject that dominated much of his research, travels and writings. 
As is obvious from his numerous articles on Indian Islamic architecture, a selection of which are reproduced in this volume, John manifested a remarkable sensitivity to indigenous constructional principles, as well as the nuances of building form and style. Underpinned by a secure command of Indian languages and history relevant to the Muslim period, his articles on Indian Islamic architecture may be considered definitive. John was a master of concentrated prose, encapsulating the maximum amount of data in the smallest possible space. Little wonder that he was attracted to producing encyclopaedic articles, since these offered him an opportunity to display his ability to summarize a complex subject into a concisely written text. Perhaps it was this flair for condensation that prevented him from working up his unparalleled knowledge of Indian Islamic architecture into a large-scale survey, though he certainly considered plans for exactly such a work. In addition to his capabilities as a researcher and author, John developed an uncanny ability as an observer. He was able to focus on an individual attribute of a building that revealed its inherent technical or stylistic personality. Thus, for example, in his extended essay on the evolution of Islamic architecture in Ahmadabad in Gujarat, reproduced in its entirety in this volume, John considers a large number of mosques and tombs, assigning each a distinctive structural or stylistic feature. His architectural descriptions, though generously supplied with detail, are infused with insights and never become repetitive.

Nowhere is John's command of the subject and writing skills better revealed than in the numerous pieces that he wrote for successive volumes of EI that appeared between 1960 and 1995. They include discussions of particular Islamic building typologies, such as mosques (Masjid), public places of prayer (Namazgarh), funerary structures (Makbara), wells (Baoli), fortification towers (Burdj), canals (Naht) and ornamental water channels and fountains $\left(\mathrm{Ma}^{\mathrm{C}}\right)$. There are also separate treatments of individual architectural features, like mosque-pulpits (Minbar), minarets (Manara) and parasol-like pavilions, or chhatris (Mirzalla), as well as a consideration of the role of Arabic and Persian inscriptions on building facades and interiors (Kitabat). In yet another article John focused on the Star of Solomon (Sitara-i Sulayman), a decorative motif that is found in early Mughal architecture (chapter in the multiple author work edited by C.E. Bosworth).

It is, however, in his articles for $E I$ on sites of historical and architectural importance that John best displays his powers of observation and analysis, backed by personal visits and photo documentation. Among 
the capitals associated with the Sultanate and Mughal rulers there is a detailed treatment of Delhi (Dilhi) throughout all phases of its history, spanning some 500 years, as well as more condensed entries on Bidar, Champaner (Campaner), Gulbarga, Hyderabad (Hayderabad) and Jaunpur (Djawnpur). (To these must be added the extensive article on Ahmadabad that appeared in a Marg monograph, reproduced in this volume.) Entries on the history and architecture of cities that served as headquarters for provincial governors during Sultanate and Mughal times include Baroach (Bharoc), Bidar, Chanderi (Canderi), Daulatabad (Dawlatabad), Dhar, Hansi, Idar and Nagore (Nagawr). Lesser centres with evidence of building activity are also covered, such as Jalor (Djalor), Etawa (Itawa), Kalpi, Kanauj (Kanawdj), Maner and Narnaul (Narnawl). And then there are remotely located and rarely visited citadels with structural remains, like Gawligarh, Kalyani, Kandahar, Mahur, Naldrug and Narnala, for which John wrote what must be considered pioneering descriptions. Another little known site that John investigated is Thalner, headquarters of the early Faruqi sultans on the Tapti river; his field report is published here for the first time.

This series of articles is accompanied by others in $E I$ that concentrate on Indian Islamic dynasties, such as the Bahmanis, Barid Shahis, Lodis and Mughals; the last of these is a multi-author entry, for which John contributed extended sections on history and numismatics. Then there are treatments of particular regions, giving the politico-geographical backgrounds to local architectural styles: thus Bihar, Gujarat (Gudjarat), Hyderabad (Haydarabad) state, Karnatak, Khandesh, Mewar and Mirath (Meerut). The most wide-ranging of these pieces is the multiauthor introductory entry on India (Hind), for which John wrote the sections on languages and on Muslim architecture (the latter reproduced in this volume). John was also responsible for separate pieces on the Yamuna (Djamna) and Ganga rivers.

John's entries for $E I$ also embrace a number of miniature biographical pieces, demonstrating his wide interest in the Muslim period. Here we find accounts of the lives of royal figures such as Humayun Shah Bahmani of Bidar, Ahmad Nizam Shah and Husayn Nizam Shah of Amadnagar, Hushang Shah Ghuri of Mandu and Ibrahim Shah Sharki of Jaunpur. Then there are the careers of the Princes Mirza 'Askari, the third son of Babur, and Daniyal, the youngest son of Akbar, and Mirza Aziz 'Koka', his foster-brother. Among military figures that John writes about are Jalal al-Din Ahasan, one of Muhammad bin Tughluq's commanders, destined to become the first independent sultan of Madura(i); 
and Raja Man Singh, the outstanding general of the Mughal forces under Akbar. John's interests also encompassed the religious life of Muslim India and his commissions for EI include biographies of Jafar Sharif, author of Kanan-i Islam, a work that describes the beliefs and practices of South Indian Muslims; Ahmad Hanswari, a Sufi mystic of the Chisthi order; and Ni'mat Allah and his family, who introduced the teachings of the Persian Ni'mat Allahiyya order to the Bahmani court. In other articles John discusses particular communities in India: thus Jains, and their relationship with the Mughal emperors; Habshis, the African slaves who rose to prominence at the various sultanate courts; and Hindus, as seen from the point of view of Muslim writers and geographers, as well as by Akbar himself.

John was fascinated by religious practices of Muslim India and wrote two pieces in $E I$ on the auspicious viewing of a deity or human figure (Darshan), as adopted by Akbar and other Mughal emperors, and worship of footprints and other relics of the Prophet (Kadam Sharif), and the shrines built expressly for this purpose. The entry on war (Harb), co-authored with S.A.A. Rizvi, covers the choice of battle grounds, order of battle, strategy and tactics, and tricks and stratagems. There are also articles on Mawalkib, or processions, such as wedding ceremonies, courtly pageants, royal hunts and the parades of Muharram; on Marasim, the ceremonial etiquette at the Muslim courts, especially the practice of darbar; on Nithar, the distribution of largesse by scattering coins, much beloved by Muslim rulers and their subjects; and on royal kitchens and cuisine (Matbakh). Courtly titles are considered in entries on Khaja-i Jahan (Khadja-i Djahan), used for various sorts of dignitaries; Mir (from amir) and Mirza, adopted by nobles in both the Sultanate and Mughal administrations; Mushrif, an overseer, supervisor or accountant general; and Nakib, an official responsible for royal proclamations, but who often assumed a military role. John also wrote entries on the mint (Dar al Darb), in which he discusses coinage in Sultanate and Mughal India, and on tax (Dariba), where he deals with land revenues and cash salaries; measures of length and area used for land assessments are described in Misala. In his imaginative article on the balance (al-Mizan) John considers pictorial representations of the Mughal emperors seated in metal pans, weighed against coins and precious stones.

In addition to these diverse encyclopaedic entries John was a conscientious book reviewer, regularly supplying contribution to $B S O A S$ over a period of more than 20 years. Here too can be seen John's overall 
shift in interest from studies on linguistics relevant to South Asian languages to works on Indian Islamic history, culture and architecture. Two reviews may be singled out, since they provided John with opportunities for broad ranging discussions. An extended article in BSOAS focusing on Sidney Toy's Strongholds of India ("A study of fortification...") gave John an excuse to comment on the inadequate state of knowledge of the subject, and lament the lack of reliable maps for even the most important fortified cities and hilltop citadels of Muslim India. His comments on Z.A. Desai's Indo-Islamic architecture in Art and Archaeology Research Papers drew attention to several well-entrenched, but nonetheless uncertain identifications and datings. John much admired Desai's broad introductory approach to the subject, and doubtless hoped that one day he might supplement this work with a volume of his own.

$$
\text { * * * }
$$

This somewhat cursory listing of John's entries in EI and various journals and multi-author works, together with a brief mention of his book reviews, can hardly do justice to John's command of virtually all aspects of Indian Muslim history, culture and architecture. Hopefully these notices will serve to supplement the articles on building typologies and historical sites that are reproduced in full here, for in the end it is John's writings on Indian Islamic architecture that form the most coherent body of work. Though John was never able to realize his ambition of authoring a comprehensive survey of Indo-Islamic architecture, his articles, when assembled together, as in this volume, give the best possible idea of what he probably intended to do. Occasionally out of date from the point of view of recent research and bibliographic references, they are nonetheless brimming with essential data that should benefit scholars, students and travellers alike. 


\section{JOHN BURTON-PAGE: BIBLIOGRAPHY}

1. Entries in Encyclopaedia of IsLam, New EDition,

volumes I-III, Leiden, E.J. BRILl and London, LuZaG \& Co. 1965-71, volumes IV-VIII, Leiden, E.J. BRILl 1978-95

"Bahmanis, Monuments," I (1965), 925-6.

"Baoli," I (1965), 1024.

"Barid Shahis, II. Monuments," I (1965), 1047-8.

"Bharoc," I (1965), 1193.

"Bidar, with H.K. Sherwani," I (1965), 1199-1201.

"Bidjapur," I (1965), 1203-4.

"Bihar," I (1965), 1209-10.

"Burdj, III. The tower in Islamic architecture in India," I (1965), 1321-4.

"Campaner," II (1965), 10-1.

"Canderi," II (1965), 12-3.

"Dal," II (1965), 101.

"Daniyal," II (1965), 113.

"Dar al Darb, India," II (1965), 119-21.

"Dariba, b. The early Mughals; c. The later Mughals," II (1965), $155-8$.

"Dashan," II (1965), 162.

"Dawlatabad, ii. Monuments," II (1965), 179-80.

"Dawud Khan Kararani," II (1965), 183.

"Dhal," II (1965), 217-8.

"Dhar," II (1965), 219.

"Dilhi, 1. History; 2. Monuments," II (1965), 255-66.

"Dilhi Sultanate, Art," II (1965), 274.

"Dja far Sharif," II (1965), 375.

"Djalal al-Din Ahsan, II (1965), 391.

"Djalor," II (1965), 405.

"Djamna," II (1965), 437-8.

"Djawnpur," II (1965), 498-9.

"Djayn," II (1965), 503.

"Djim," II (1965), 545.

"Durbash,” II (1965), 627-8. 
"Elura," II (1965), 695.

"Ganga," II (1965), 976.

"Gawligarh," II (1965), 981.

"Gudjarat, a. Ancient history; b. Under the Dilhi sultanate; c. the sultanate of Gudjarat," II (1965), 1123-30.

"Gudjrat," II (1965), 1131.

"Gulbarga," II (1965), 1135.

"Ha, iii. Indian languages," III (1971), 2-3.

"Habshi," III (1971), 14-6.

"Hampi," III (1971), 147-8.

"Hansawi," III (1971), 167.

"Hansi," III (1971), 167-8.

"Harb, vi. India" (with S.A.A. Rizvi), III (1971), 198-203.

"Hariyana," III (1971), 225.

"Hasan Abdal," III (1971), 245.

"Haydarabad," III (1971), 318-23.

"Hind, iii. Languages; iv. History; vii. Architecture," III (1971), 412-28 and 440-52.

"Hindi," III (1971), 456-8.

"Hindu," III (1971), 458-9.

"Hindustani," III (1971), 460-1.

"Hulagu," III (1971), 569-70.

"Humayun Shah Bahmani," III (1971), 577.

"Husayn Nizam Shah," III (1971), 625-6.

"Hushang Shah Ghuri," III (1971), 638-9.

"Ibrahim Shah Sharki," III (1971), 1003.

"Idar," III (1971), 1010.

"Itawa," IV (1978), 276-7.

"Kadam Sharif," IV (1978), 368.

"Kalpi," IV (1978), 513.

"Kalyani," IV (1978), 513-4.

"Kanawdj," IV (1978), 533-4.

"Kandahar," IV (1978), 538

"Karnatak," IV (1978), 666-7.

"Khadja-i Djahan," IV (1978), 907-8.

"Khandesh," IV (1978), 1022-4.

"Khayrabad," IV (1978), 1159.

"Kitabat, 10. India" V (1986), 231-3.

"Lodis, 4. Architecture; 5. Coinage," V (1986), 785. 
"Ma', 12. Ornamental uses of water in Muslim India," V (1986), 888-9.

"Mahim," V (1986), 1258.

"Mahmud Khan," VI (1991), 61.

"Mahur," VI (1991), 87.

"Makayil, 2. In Muslim India," VI (1991), 121-2.

"Makbara," VI (1991), 125-8.

"Malik Ahmad Bahri," VI (1991), 269.

"Man Singh," VI (1991), 342-3.

"Manara, Manar, 2. In India," VI (1991), 368-70.

"Maner," VI (1991), 409-10.

"Marasum, 5. In Muslim India," VI (1991), 532-4.

"Marathi," VI (1991), 536.

"Maratib," VI (1991), 536-7.

"Masjid, II. In Muslim India, A. Typology," VI (1991), 688-90.

"Matbakh, 4. In Mughal India" VI (1991), 813-5.

"Mathura," VI (1991), 839.

"Mawakib, 5. In Muslim India," VI (1991), 865-7.

"Medini Rai," VI (1991), 970.

"Meo," VI (1991), 1019.

"Mewar," VI (1991), 1027-8.

"Mewat," VI (1991), 1028-9.

"Minbar, 3. In India," VII (1993), 79-80.

"Mir," VII (1993), 87-8.

"Mirath," VII (1993), 113.

"Mirza, 2. In Indian usage," VII (1993), 129.

"Mirza 'Aksari," VII (1993), 130-1.

"Mirza Aziz 'Koka'," VII (1993), 131-2.

"Mirzas," VII (1993), 133-5.

"Mizalla, 5. In Indo-Islamic architecture," VII (1993), 194-5.

"al-Mizan, 3. Aspects of the balance in Indian Muslim art," VII (1993), 204.

"Mudgal," VII (1993), 289.

"Mughals, 1. History and 11. Numismatics," VII (1993), 313-6 and 344-6.

"Mushrif," VII (1993), 678-80.

"Nagawr," VII (1993), 898.

"Nahr, 2. In Muslim India." VII (1993), 909-10.

"Nakib, 2. In India." VII (1993), 926. 
"Nakal," VII (1993), 932-3.

"Naldrug," VII (1993), 943.

"Nazamgarh," VII (1993), 947.

"Nander," VII (1993), 957.

"Narnala," VII (1993), 965.

"Narnawl," VII (1993), 965-6.

"Mishala, 2. Muslim India," VII (1993), 138-40.

"Ni'mat-Allahiyya, 2. Ni'mat Allah and his family at the Bahmani court,"

VIII (1995), 48.

"Nithar," VII, VIII (1995), 64.

"Nun," VIII (1995), 121.

"Pandj Pir," VIII (1995), 252.

\section{Articles in Agademic Journals}

Bulletin of the School of Oriental and African Studies

"The name 'Nepal,", 16 (1954), 592-7.

"Two studies in Gurungkura, 1. Tone; 2. Rhotacism and retroflexion," 17 (1955), 111-9.

"The syntax of participal forms in Hindi," 19 (1957), 94-104.

"The charm of Indo-Islamic architecture, an introduction to the northern phase," 19 (1957), 393-4.

"Compound and conjunct verbs in Hindi," 19 (1957), 469-78.

“'Aziz' and the sack of Dwarka, a seventeenth century Hindi version," 20 (1957), 145-57.

"Notes on two problems in Indo-Aryan," 21 (1958), 174-8.

"A study of fortification in the Indian subcontinent from the thirteenth to the eighteenth century A.D.," 23 (1960), 516-22.

"An inscription from Ambur fort in the Victoria and Albert Museum," 49 (1986), 552-60.

\section{Indian Linguistics}

"An analysis of the syllable in Boro," 16 (1956), 334-4.

"The gender of loan-words in Hindi," 20 (1959), 165-79.

Bulletin of the Deccan College

"The etymology of Hindi jagah, a problem in diffusion," 20 (1960), 288-90. 
Art and Archaeology Research Papers

"Indo-Islamic architecture, a commentary on some false assumptions," 6 (1974), 14-21.

\section{Fournal of the Royal Asiatic Society}

"Muslim graves of the lesser tradition', Gilgit, Punial, Swat, Yusufzai," $1986,248-54$.

\section{Articles in Multiple Author Works}

"Verbum compositum and verbum conjunctum in Hindi." In Akten des XXIV. Int. Or. Kongr., Munchen, 1957, 577-8, Munich, 1959.

"Isfahan," "Tomb of Rukn-i Alam," "Lahore Fort," "Wazir Khan's Mosque," "The Red Fort," "Fatehpur Sikri" and "Taj Mahal." In Splendours of the East, Temples, Tombs, Palaces and Fortresses of Asia, ed. M. Wheeler, 46-57, 72-101 and 130-65, London 1965.

"The problem of the introduction of Adansonia digitata into India." In

The Domestication and Exploitation of Plants and Animals, eds. P.J. Ucko and G.W. Dimbleby, 331-5, London 1969

"Preface." In T.W. Clark, Introduction to Nepali, A First Year Language Course. London, University of London School of Oriental and African Studies, 1977.

"Daulatabad," and "Bijapur." In Islamic Heritage of the Deccan, ed. G. Michell, 16-25 and 58-75, Bombay 1986.

"Historical Context" and "Mosques and Tombs." In Ahmadabad, eds.

G. Michell and S. Shah, 6-15 and 30-119, Bombay 1988.

"The Sitara-i Sulayman in Indian Muslim art." In The Islamic World from

Classical to Modern Times, Essays in Honour of Bernard Lewis. eds. G.E. Bosworth et al., 75-87, Princeton, NJ, 1989.

"The early Vrindavana temples, the 'Hindu-Muslim' synthesis rejected."

In Govindadeva, A Dialogue in Stone, ed. M.H. Case, 123-7, New Delhi 1996.

\section{Felicitation and Obituaries}

"To Sir Mortimer Wheeler," In Studies in Honour of Sir Mortimer Wheeler, Fournal of the Royal Asiatic Society, 1970, i-iii.

"Sir Ralph Turner," Journal of the Royal Asiatic Society, 1984, 257-9. 
"John Brough," Bulletin of the School of Oriental and African Studies, 48 (1985), 333-9.

\section{Book Reviews}

Fournal of the Royal Asiatic Society

W.R.J. Moreland-Hughes, A Grammar of the Nepali Grammar, 1950, 205-6.

Kushwant Singh, The Sikhs, 1954, 189.

Bulletin of the School of Oriental and African Studies

J. Wackernagel, Altindhische Grammatik, Bd. II, ii, Die Nominal-suffixe von Albert Debrunner, 18 (1956), 188-90.

V.S. Agrawal, Padmavati, mul or sajioni vyakhya, 19 (1957), 184-5.

Hindi Reviere, the English Organ of the Nagari Pracharini Sabha, 19 (1957), 185.

G.H. Fairbanks and others, Hindi Exercises and Readings, 19 (1957), 387-8.

J. Terry, The Charm of Indo-Islamic Architecture, 19 (1957), 393-4.

Contemporary Indian Literature, A Symposium, 21 (1958), 197-8.

J. Wackernagel, Altindische Grammatik, Nachtrage zu Bd.II. von Albert Debrunner, 21 (1958), 440.

V.S. Agrawal, Bharat-Savitri, 21 (1958), 442.

J.C.E. Bowen, The Golden Pomegranate, 21 (1958), 444.

L.D. Barnett and others, Second Supplementary Catalogue of Printed Books in Hindi ... in the Library of the British Museum, 23 (1960), 159.

S. Sarma and R. Mubarijuddin, ed., Ali Adil Sah ka kavy-sagrah, 23 (1960), 204.

L. Rocher, Manual of Modern Hindi, 23 (1960), 204.

H. Berger, Zwei Probleme der mittel-indische Lautlehre, 23 (1960), 424.

J. Kurylowicz, L'apophonie en Indo-europeen, 23 (1960), 424-5.

J. Wackernagel, Altindische Grammatik, Introduction General...par Louis Renou and Nachtrage zur Bd. I von Albert Debrunner, 23 (1960), 425.

B.N. Prasad, ed., Muralidhar Kavibhusan krt Chandohrdayprakas, 23 (1960), 425-6.

P. Hacker, Zur Funktion einiger Hilfsverben in Modernen Hindi, 23 (1960), 602-3.

Ch. Vaudeville, Kabir granthavali, 23 (1960), 626.

V.S. Agrawal, Kadambari, 23 (1960), 626-7. 
C.A. Fergusson and J.J. Gumperz, Linguistic Diversity in South Asia, 23 (1960), 627.

W.T. de Bary and others, Sources of Indian Tradition, 23 (1960), 627-8.

A.H. Dani, Muslim Architecture in Bengal, 25 (1962), 626-7.

D.H. Simpson, Biography Catalogue of the Library of the Royal Commonwealth Society, 25 (1962), 650-1.

F.R. Allchin, tr., Tulsi Das, Kavitavali, 28 (1965), 403-4.

S.C. Misra, Muslim Communities in Gujarat, 28 (1965), 411-2.

M. Sadiqi, A History of Urdu Literature, 29 (1966), 174-5.

A. Karim, Dacca, the Mughal Capital, 29 (1966), 200-1.

M. Hurlimann, Delhi, Agra, Fatehpur Sikri, 29 (1966), 201-2.

Studies in Islamic Art and Architecture in Honour of K.A.C. Creswell, 29 (1966), 390-1.

V. Porizka, Hindstina, Hindi Language Course, 29 (1966), 397-8.

D. Talbot Rice, Islamic Art, 29 (1966), 392-3.

D. Hill and O. Grabar, Islamic Architecture and its Decoration, 29 (1966), 393-4.

S.D. Singh, Ancient Indian Warfare, 29 (1966), 398-9.

K.A. Nizami, Some Aspects of Religion and Politics in India during the Thirteenth Century, 29 (1966), 451.

V.N. Misra and M.S. Mate, ed., Indian Prehistory, 1964, 31 (1968), $162-4$.

P. Saran, comp., Descriptive Catalogue of Non-Persian Sources of Medieval Indian History..., 31 (1968), 165-6.

K. Qanungo, Sher Shah and His Times, 31 (1968), 166-7.

Wheeler, Sir M., Civilizations of the Indus Valley and Beyond, 31 (1968), 207.

U. Monneret de Villard, Introduzione alla studio dell'archeologia islamica..., 32 (1969), 154-5.

E. Kuhnel, Islamic Art and Architecture, 32 (1969), 155-7.

E.J. Grube, The World of Islam, 32 (1969), 157-8.

B.N. Goswamy and J.S. Grewal, ed. and tr., The Mughals and the Fogis of Jakhbar..., 32 (1969), 178-9.

S.R. Rao, Excavations at Amereli, a Kshatrapa-Gupta Town, 33 (1970), 644-5.

A. Ghosh, Ajanta Murals, 33 (1970), 695-6.

M. Archer, British Drawings in the India Office Library, 35 (1972), 645-7.

K.A.C. Creswell, Early Muslim Architecture, Vol. 1, second edition, 37 (1974), 231-2.

R. Islam, Indo-Persian Relations, A Study of the Political and Diplomatic Relations between the Mughal Empire and Iran, 37 (1974), 246-7. 
xxiv

JOHN BURTON-PAGE: BIBLIOGRAPHY

R. Ettinghausen, ed., Islamic Art in the Metropolitan Museum of Art, 39 (1976), 713-4.

B.W. Robinson, Islamic Painting and the Arts of the Book, 42 (1979), 153.

Antiquaries' fournal

S. Toy, The Fortified Cities of India, 1966. 


\section{INTRODUCTION}




\title{
SULTANATE ARGHITECTURE*
}

\author{
Pre-Islamic Tradition
}

At the time of the Muslim conquest, India was a land with a rich artistic tradition: temples and monasteries abounded, Hindu shrines of all descriptions and sizes were found by almost every hillside and spring, cities were rich and well-planned, Hindu rulers had built for themselves forts and palaces, and the remains of earlier phases of Indian civilization - such as the Hindu, Buddhist and Jain cave-temples, and the Buddhist stüpas and monasteries - were numerous. Architecture was characteristically of stone, its construction derived from timber prototypes: beams and lintels were supported on columns or brackets, and roofs tended to a stepped pyramidal shape, through having been built in diminishing horizontal courses. Domical shapes were known, often carried on octagonal bases, but were often solid and in any case had little structural affinity with the true voussoir-built dome. The northern temples usually had curvilinear towers, again often solid; these, and some of the domical forms, had a characteristic crowning feature which later became part of the Indian Islamic dome decoration, a ribbed ring known as ammalaka (from the fruit it resembles, the Emblic Myrobalan, Phyllanthus emblica) surmounted by a pot-shaped moulding, the kalaśa (lit. 'water-jar'); to these a base of stone foliations in the form of lotus-petals might be added. The entire ornamental feature was on occasions supported by ribs on the curvilinear towers, and it has been suggested that at least part of the origin of ribbed domes in India is to be found in this device. The arch is not known at all as a structure, and only rarely as a decorative form; but recesses used freely on both internal and external walls lead to a proliferation of vertical lines and to unnecessary horizontal plinths and mouldings. Window-openings were rare: the interior of the Hindu temple was poorly lighted, its kernel being the secret shrine of an idol god whose mysteries were known only to a few initiated priests and were not for public display. The exterior, however, was as luxuriant and prolix as

* "Hind, vii. Architecture," EI, III, 440-8. 
the interior was esoteric and recondite, for all its surfaces were covered with a profusion of exuberant sculpture of iconographic significance, in which the human form preponderated. Free-standing statuary was also known, with the human form again dominant; but frequent also were the vehicles and attendants of the Hindu gods, especially Shiva's bull, and also the linga, the representation of the phallus as the generative principle of the world.

\section{EArliest Islamic Architegture}

There is as yet insufficient archaeological evidence of the first Islamic buildings on Indian soil which must have been produced by the conquest of Sindh in the 8th century, although excavation at present being undertaken at Bhambor (Pakistan) and elsewhere may eventually reveal the site of Daybul. The buildings after the 12th century conquest of the north, however, show the Muslims' reaction to indigenous building very plainly; for the traditions of the idol-temples, with their plethora of florid figure representation, their gloom and secrecy, and above all the nature of the worship they implied, were not only anathema to Islam but were its direct antithesis.

The earliest phase of Muslim building is in Delhi, and is here represented by the re-use of pillaged material from Hindu and Jain temples; destruction of the religious buildings of the enemy is known, of course, in many religions other than Islam, and indeed in India there is more than one record of a Hindu king doing just this to his neighbour's lands. Reutilization of the pillaged material is a feature of the initial phase of Muslim occupation in many regions of India, for example, at Ajmer and Jalor in Rajasthan; Bharoch, Cambay (Khambayat) and Patan in Gujarat; Jaunpur; Bijapur, Daulatabad and Warangal in the Deccan; Gaur (Lakhnauti), Pandua and Tribeni in Bengal; Dhar and Mandu in Malwa; and many other sites. The first example, the Masjid Quwwat al-Islām at Delhi, is in fact built on a temple plinth, and some 27 temples were pillaged to provide columns, walls, roofing materials, and paving; sculptured figures were mutilated or were so set in walls that the unworked sides of the stones were all that could be seen. This mosque was at first a plain enclosure, but in 595/1199, eight years after its foundation, a large maqșüra screen was erected between the western liwarn and the courtyard, and the arch appears for the first time: but these arches are corbelled out, not voussoired, and it appears that the work 
was done by Hindu artisans working under general Muslim direction and as yet having no mastery over the alien architectonic forms; moreover, the courtyard side of the maqsüra is covered with carving, mostly typical Hindu floral motifs and ornaments, but also some bandeaux of naskh calligraphy, in such a way as to suggest that local workmanship was being employed. In the south-east corner of the mosque buildings the minaret known as the Quṭb Mīnār presents a stylistic contrast, as its tapering fluted storeys develop the polygonal outline of the minnars at Ghazni (Afghanistan) which must be its immediate prototype, and features of typically Hindu derivation are almost entirely absent.

The extension of the Quwwat al-Islām mosque and the first completion of the min̄arr were carried out by Iletmish in the early 13th century, and to his reign belong the Arhā' $\overline{1}$ din kā Jhōmprā mosque at Ajmer, his own tomb of $c$. 632/1235, and his son's tomb of 629/1231, the earliest monumental tomb in India (there are earlier dated tombstones, as at Hansi); also minor buildings at Delhi and Badaun (the Jāmi Masjid has been so much repaired and rebuilt that scarcely any of Iletmish's fabric is visible), at Bayana, and at Nagaur. In none of these buildings is there a true arch or dome, although all the masonry has well dressed surfaces, often elaborately carved. The tomb of Iletmish's son, Nāṣir al-Dīn Maḥmūd, stands within an octagonal cell which seems to be the earliest use of the octagon in Muslim India; it appears next as the phase of transition of Iletmish's own square tomb, to support, presumably, a dome of which there is now no trace (and which, one must imagine, was also corbelled and not voussoired). In the latter tomb the octagon is formed by simple corbelled squinch arches across each corner. These early buildings are of so heterogeneous and, often, of so makeshift a nature that there is little of a coherent style about them. The buildings of the emperor Balban, similarly, are few and largely uninteresting, except for the significant appearance of the true voussoired arch in his tomb, now a mere unprepossessing lump of decaying masonry.

\section{The Delhi Sultanate}

With the Khaljī dynasty, however, a distinct if short-lived style appears, the keynote of which is provided by 'Alā' al-Dīn's southern doorway into the Masjid Quwwat al-Islām complex and known as the 'Alā' $\overline{1}$ Darwāza. This, like other examples of the style, is built with specially quarried stone and not improvised from Hindu materials; its chief 
characteristic is the shape of the arch, which is voussoired and of the pointed horseshoe shape and, in the case of external arches, has on the intrados a fringe of conventionalized stone spear-heads. The masonry is well finished and jointed, decoration in the form of bandeaux of calligraphy and a running merlon-like ornament being now more prominent that the diaper and rosette patterns in basso relievo with which the earlier builders were wont to cover entire walls. At the 'Alā'ī Darwāza, but not in the other examples of Khalji work, the entire surfaces are so treated, and in addition show the use of white marble bandeaux of inscriptions, pilasters and architraves. Works of similar style exist at Delhi (the so-called Jamā'at Khāna mosque at the shrine of Niẓām alDīn Auliyā') and Bayana; but other buildings of the Khaljī period are found as far afield as Jalor in Rajasthan, at Bharoch, Cambay, Patan and Siddhpur in Gujarat, at Bhilsa in Malwa, in Daulatabad in the northern Deccan, and elsewhere, many of these incorporating much pillaged temple material but showing also many of the characteristics mentioned above, and most significant in pointing out the expansion of this early Sultanate style.

Under the Tughluq dynasty the Delhi empire was greatly extended, and with the expansion came the spread of the Delhi style of all parts of that empire. Of the works of the first ruler, Ghiyāth al-Dīn Tughluq, there are insufficient remains to show how early the Tughluq traits developed: besides the ruins of his capital city, Tughluqābād, only his own tomb. But a major works for which he was responsible before his accession to the Delhi throne is the mausoleum of the saint Rukn-i 'Âlam at Multan (Pakistan), originally intended as his own tomb. Some features of this, especially the batter of the walls and the sloping corner turrets, are reflected in the walls of Tughluqābād and in the strong batter of Tughluq's tomb; and perhaps the profile of the dome also is closer to the pointed Multan model than to the shallow domes of the 'Alā'ī Darwāza and the Jamā'at Khāna of the preceding dynasty. The characteristic Multani features of raised tilework and wooden structural courses, described below when the Panjab style is considered, are however absent in the extant Delhi examples; nor is the octagonal shape retained. Tughluq's son Muhammad b. Tughluq shortly after his accession conceived the grandiose idea of forming a second capital at Daulatabad and transporting there the elite population of Delhi, and the necessary services. The old Hindu fort, the former Devagiri, at the new capital was much extended, and it seems likely that the Khaljī mosque there was modified at this time since its rear wall has tapering 
angle turrets, although its interior arrangements seem undisturbed. Muhammad's occupation of Daulatabad was only for about five years, after which he returned to Delhi, where most of his building projects were carried out. His administration seems to have impoverished the royal treasury, and the fine stonework of earlier reigns almost disappears and is replaced by cheaper material, plaster over a rubble core; but, from the sudden appearance in the 14th century of buildings in the Deccan which are obviously close to the earlier Delhi styles, it is to be supposed that many of the artisans taken to Daulatabad drifted away from that centre and formed other allegiances: certainly the earliest Bahmanī tombs at Gulbarga would support this view. Muhammad b. Tughluq's royal palaces at Delhi, the Bijay Mandal and the Hazār Sutūn, are now in too ruined a state to permit of certain conclusions as to architectural style; the majority of the remains of his period in Delhi are in fact more commonplace works: the fort walls of 'A dilābād and Jahānpanāh, and the interesting sluice or water-regulator called Sāt Pulāh. The only significant innovation is to be found in the Bijay Mandal remains: the earliest Indian example of intersecting vaulting. Some ceramic fragments are known from the 'Ádilābād excavations.

Under Muhammad's nephew Fīrūz Shāh Tughluq the building art received an enthusiastic patron. Not only did he build extensively on his own account, but he arranged for the renovation or restoration of many of the monuments of his predecessors. But a strict economy had now to be practised, and plans and costings for each projected undertaking came first under the scrutiny of the dīwān-i wizāra. Red sandstone and marble were no longer used, and in Delhi the favourite materials were the local quartzite for columns, jambs, arches and reveals, with the other elements built of compact plaster, usually whitewashed, over a random rubble core. Ornament is generally reduced to a minimum, and where it exists it is more usually of moulded plaster than of carved stone. The sombre and ascetic effect of this architecture produced under conditions of financial stringency is in marked contrast to the exuberance of plastic ornament of the preceding regimes, and was certainly foreign to the instincts of the traditional Indian craftsman. But aspects of the Hindu tradition are certainly found in buildings of this phase, exemplified in the use of beam-and-bracket construction for many of the openings - a main doorway tends to show a large arched opening in which a smaller opening of lintel-and-bracket construction is recessed; but this device is met with earlier in Ghiyāth al-Dīn Tughluq's tomb-and in the use of sloping eaves $($ chhajja $)$ supported on corbels, which now appears for the 
first time. An innovation which seems to be of extra-Indian provenance, however, is the machicolation which now appears in fortified works. There seems also to have been some experiment in the planning of mosques: the courtyards of the Sanjar mosque at Nizāmuddīn and the mosque at Khirkī village are both partially covered. Several mosques are now built on a high plinth over a tahkhāna storey and are approached by flights of steps, and a frequent device is the flanking of a gateway or a mihrāb buttress by a pair of tapering pillars; roofs now begin to show a multiplication of domes, and domed corner turrets appear in many works (those in Sultān Ghārī, the tomb of Iletmish's son, are most probably to be attributed to Fīrūz Tughluq's renovations). One innovation, in the mosque of Begampur, is a feature of many later styles and was probably introduced from the region of Jaunpur after Fìrūz's conquest of that region: the central bay of the façade of the western tīwān is occupied by a tall arched pylon which completely conceals the large central dome from the courtyard. Most of the tombs of the period are of the square type, including Fìrūz's own, but of great architectural significance is that of his wazīr Khān-i Jahān Tilangānī, d. 770/1368-9, which is octagonal; the tomb-chamber is surrounded by a verandah with a shallow dome-like cupola and three arched openings on each of the eight sides, continuous eaves, and a single central dome crowned by the amalaka motif. The tomb is surrounded with a fortified enclosure. Other buildings of Fīrūz Tughluq are known from Jaunpur, Fathabad, where a pillar in the fort records Fīrūz's lineage, and Hisar; many of these, reflecting a stage of new conquest or refoundation, are improvizations from Hindu material, but show in addition some regional trends not apparent in the buildings of the capital: thus the now destroyed Chihil Sutūn at Jaunpur was entirely trabeate, was roofed on its upper storey with a curvilinear ribbed pyramid, and was decorated with stone stringcourses, parapets and plinth. Two buildings of the end of the Tughluq period show perhaps a reaction to the Fìrūzian austerity: the tomb of Kabīr al-Dīn Auliyā' at Delhi, a poor and half-scale copy of the tomb of Ghiyāth al-Dīn Tughluq, showing a revival of polychromatic work in red sandstone and white marble, and the Jāmi' Masjid at Irich, entirely arcuate with some good stonework, and exhibiting in its façade arches and squinches a recession of planes, a familiar device under succeeding dynasties.

The sack of Delhi by Tīmūr in 801/1398-9 left the sultanate with little resources and less prestige, and for many years the building art in the region of the capital is represented almost entirely by tombs. The 
tombs of the so-called "Sayyid" rulers are octagonal, continuing the tradition of the Tilangānī tomb with structural improvements, especially in raising the springing of the dome by a tall drum; and the shallow domes over the octagonal arcade have been replaced by small pillared kiosks (chhatriss, lit. 'umbrellas') - the beginnings of a feature which later is to characterize the architecture of many schools, including the Mughal; and the batter of the outer walls is retained. The Lōdi monuments show the gradual rehabilitation of the building art, although indeed most of these also are tombs. There is a series of monumental tombs, mostly anonymous, at various sites in the southern part of Delhi, all of a square type not previously known in the north, since all their upright lines are truly vertical and there is no batter. The area of their ground-plans is less than that of the octagonal tombs, but their height is greater; and their side walls are often broken up to the eye by dividing each façade with deep stringcourses with sunk blind arches above and below to give the impression of two or three storeys, although the interior is a single square cell; frequently a central bay of each side is extended upwards to enclose a main arch of nearly the whole height of the wall, the actual doorway being set in this arch with a lintel-and-bracket; and the west wall is usually closed to accommodate a mikrāb.

But Lōdī tombs also exist in the octagonal style, including - apart from numerous octagonal pillared pavilions - the fine tomb of ' $\mathrm{Al} \overline{\mathrm{a}}$ ' al-Dīn 'Ālam, the largest of the series, at Tijara, and the tomb of Sikandar, c. 924/1518, at the Delhi suburb of Khayrpur. The latter perhaps represents the link between the former habit of placing tombs in a fortified enclosure, of which the Tilangānī tomb is the last extant example, and the Mughal practice of surrounding the mausoleum by a garden; for this tomb stands in a large walled enclosure with decorative corner turrets and an ornamental doorway. Part of the west wall is built upwards and buttressed to form an additional external mihrāb, and is presumably a qānati mosque; the feature is known in other tombs of this period. Here, as in some of the square tombs, part of the external surface is embellished with glazed tiles, mostly blues and greens; and the dome, as in the earlier tomb of Shīhāb al-Dīn Tāj Khān, c. 906/1501, has an inner and outer shell.

Two Delhi mosques of the period are particularly significant in the development of the Lōdī style which persists until well into the Mughal period; the mosque of Abū Amjad at Khayrpur, of 899/1494, has massive tapering pillars at each rear angle, and also flanking the buttress of the mihra $\bar{a} b$, each with a band of vertical fluting alternately angled and 
rounded as in the lowest storey of the Quṭb Mīnār, the central bay of the façade projected outwards and upwards, a succession of receding architraves and soffits in each arched opening, and incidentally the finest cut-plaster decoration in Delhi. The other mosque approaches more nearly the type of the early Mughal and Sūrī periods; this is the Mōth kī Masjid of c. 911/1505, where the tapering buttresses are confined to a position flanking the milhräb projection on the west wall, and the rear angles are furnished with two-storeyed open octagonal towers. The pylon-like frame of the central arch, and the recession of planes in the arch outlines, are similar to those of the Khayrpur mosque; but as well as fine cut-plaster the decoration includes coloured tilework and the contrasting use of red sandstone and white marble. The interior is also remarkable for the stalactite pendentives which support the side domes (the main dome is carried on squinch arches).

This mosque design is continued in the Jamālì mosque of 943/1536 thus in the reign of Humāyūn; but this is the date of completion - where the stonework is of very high quality; the central archway of the façade of the west liwe an is very much taller, so that its arch reaches above the parapet level of the side aisles, and the fluted buttresses appear flanking this pylon on the courtyard side; and the intrados of that arch is decorated with the spearhead fringe. Beside the mosque is the tomb of Jamālī, externally unpretentious but still containing the finest coloured decoration in the whole of Delhi. The Jamāli mosque is the immediate model for the mosque built by Shēr Shāh Sūrī in the citadel of his new city of Delhi, where every feature is elaborated and refined, and polychromatic faience takes its place in the external ornament. Outside Delhi there is a small amount of Lōdī work, much of it still inadequately studied, especially of the time of Sikandar Lōdī, who made Agra his capital; especially noteworthy is the large mausoleum called Chaurāsī Gunbad at Kalpi. One mausoleum at Delhi, that of 'İsā Khān Niyāzī, shows the persistence of the octagonal variety of tomb well into the Sūrī period (954/1547-8), its construction being almost identical to that of Muhammad Shāh erected over a hundred years before; but here there are more traces of encaustic tile decoration, and a large separate mosque stands on the western wall of the outer enclosure, its central dome flanked by two chhatris over the side bays. This octagonal style goes further: in Delhi it peters out in the tomb of Adham Khān, but receives its supreme developments in the Sūrī monuments at Sasaram in Bihar. 
PANJAB

Lahore was a dependency of the Ghaznavids and the Ghürids long before the conquest of Delhi. No monuments of this early period have survived, although some pieces of woodcarving from doorways in the city, now in the Lahore Museum, retain features derived, through the Ghaznavid tradition, from Seljūq ornament. The earliest extant monuments are in Multan and Ucch (Pakistan), a series of tombs of local saints. The earliest, that of Shāh Yūsuf Gardīzī, of 547/1152, is a solid oblong building covered with blue-and-white tiles to form a plane external surface; but the later buildings are all tall domed buildings, from the tomb of Bahä al-Haqq, d. 660/1262, a square battered base surmounted by an octagonal drum and the earliest true dome in the subcontinent, to the magnificent mausoleum of Rukn-i 'Ālam, which J. Marshall, The monuments of Muslim India, in CHI, Cambridge 1937, describes as "one of the most splendid memorials ever erected in honour of the dead"; this resembles the previous examples in being built of baked brick but with some structural bonding courses of wood in addition, with a lofty second storey which forms an octagonal drum, with a hemispherical dome, and with pinnacles at each external angle, but differs from them in its lowest storey which is also an octagon, with battering faces and engaged tapering buttresses terminating in pinnacles at each outer angle. The external decoration is worked out in stringcourses of tile-faced brick and bands of raised diaper pattern, bands of calligraphy in carved brick, and the typical Multan tilework (known also at Ucch but nowhere else) wherein the main geometrical patterns are raised as much as $2 \mathrm{~cm}$. above the tile background; this adds greatly to the richness of the tilework by adding depth and a constant effect of light and shade where the sheen of a plane surface would have become dulled by the dust which pervades Multan in the summer. The interior decoration includes fine woodcarving in shisham wood, with the six-pointed star (a common Ghaznavid motif, but otherwise rare in India until early Mughal times) in the spandrels of the wooden mihra $\bar{a}$ and scrolls of arabesque ornament similar to that of the maqșüra of the Quwwat al-Islām mosque at Delhi. 
Bengal

Stone in the Bengal region (West Bengal and Bangladesh) is almost confined to the black basalt of the Rajmahall hills in the Malda District; but the fine alluvial clay is freely available, the material for the characteristic Bengali bricks and terracottas. The earliest buildings at Tribeni and Chota Pandua are mostly adaptations of pillaged Hindu temple material, using pillars built of large stones without mortar, and shallow corbelled domes; the tomb of Zafar Khān Ghāzī, of 698/1298, shows an early use of the arch, and mihrābs in finely moulded terracotta. The greatest of the early buildings, after the independence of Bengal, is the large Ādinna mosque at Hazrat Pandua, of 776/1374-5, in which again use was made of Hindu materials, although it appears that some of the stonework was original work executed by Hindu craftsmen in Muslim employment; it is enclosed by a multiple arcade which carried nearly 400 small domes, and has a large central aywän-like hall in the western liwwa $n$, with an elaborate stone mihrāb and minbar, of which the roof has fallen; the stonework is mostly a thin ashlar veneer over a brick core. In a somewhat later phase, represented by the Ēklākhī mausoleum at Pandua, the other characteristics of the Bengal style make their first appearance, notably a curve on each cornice of the square tombchamber which derives from a local method of constructing huts with bamboo rafters, octagonal corner buttresses, and ornament in terracotta and glazed tile; here the interior of the enormously thick chamber is an octagonal room which directly supports the single hemispherical dome. Some similar buildings were erected at Gaur after the 15th century under the later Ilyās Shāhī and the Husayn Shāhī rulers; the decorations became especially lavish, some domes being gilded; besides the square buildings with a curved cornice on each side appears the oblong pitched-roof building with the curved cornice on the long sides and gables at the short sides - a type later taken to Northern India at the time of Shāhjahān. Some buildings of the mid 15th century at Bagerhat (Bangladesh), built by one Khān Jahān, a renegade from the Delhi court, show corner turrets and lintel-and-bracket doors set within pointed arches very similar to those of Fīrūz Shāh Tughluq's buildings in Delhi of a century earlier, although retaining the local curved cornice. Many of these local features persist in the Bengali architecture of the Mughal period. 


\section{Uttar Pradesh}

The early buildings of Jaunpur and its suburb Zafarabad in Uttar Pradesh are adaptations of the time of Fīnūz Shāh Tughluq, who laid the foundations of a large mosque on the site of a temple to Atala Devī. This was completed, however, under the Sharqi kings, with four other mosques of similar style - all the other buildings of this once magnificent city were destroyed by Sikandar Lōdī. Again, Hindu remains were freely utilized in the construction; but the building is in coursed stone, with no plaster facing as in Delhi, and there is an abundance of stone carving of high skill. The special characteristic of the Jaunpur mosques is the immense pylon which fills the central bay of the western tiveann, completely concealing the large dome behind it, in some cases three times as high as the other bays of the tīwann. The trabeate construction is used freely within the prayer-halls and in the side arcades, although the tiw $w \bar{a}$ façades are arcuate, and are freely ornamented with recessed arches which are either blind or carry thick window grilles; and the intrados of the arch are usually decorated with the spearhead fringe. All these mosques are well finished externally, especially the mihrāa walls, and the tapered buttress, so familiar in the Delhi Sultanate buildings, is used freely at the external angles. Similar mosque styles are to be found at Banaras (Varanasi), Etawa, and Kanauj.

\section{Gujarat}

The very rich stone-building tradition of the Hindu and Jain craftsmen was appropriated by the Gujarat Muslims, and made Gujarat at once the richest and the most distinctive of the Indian regions in architecture. The artisans appear to have been less bound here than were their fellows in other regions to the whims of individual rulers or to rigid prescriptions by punctilious 'ulam $\bar{a}$, and indeed it often appears that the requirements of Islamic building rather emancipated them from the dogma of the schools of temple architecture, for of all the styles of Indian Islamic building that of Gujarat is the most Indian, and its purely local characteristics are obvious, even in the earliest stages where pillaged temple material was being used under the orders of governors of the Delhi Khaljīs. The earliest surviving Muslim building, the tomb of Shaykh Farīd at Patan of c. 700/1300, is merely a converted temple, 
and very little more organization appears in the Ādinna mosque there, of the same time, where over 1,000 rich temple pillars are assembled to a mosque plan (the building has now fallen almost entirely). In Bharoch only a little later the Jāmi' Masjid is a planned construction and not a mere improvization, for the outer walls are obviously constructed of stone cut for the purpose; but the western liwwan is of three bays which appear to be three temple mandapas used unaltered except for the obliteration of figure iconography in the ornament. The arch is not used, so that the liwan has an open pillared façade with no maqșura-screen - a mosque-type more frequent in Gujarat than in other regions. The Jāmi 'Masjid at Cambay, however, of 725/1325, does have an arched wall closing the tìwān. The walls of this mosque, of alternate deep and shallow courses, are uncharacteristic of Gujarat and recall the Khaljī workmanship of Delhi. A feature appearing here for the first time, which later becomes a favourite device in Gujarat, is a semicircular engrailed arch, of no structural significance, carried between two pillars inside the central arch of the façade; this directly copies the torana doorways of the local Hindu and Jain temples. This Cambay mosque has an entrance porch which is almost an exact copy of that of a temple at Modhera built three centuries before, as is that of Hilāl Khān Qāḍ̂̄’s mosque at Dholka (733/1333); but here there is another significant innovation: the façade is ornamented with two tall turrets flanking the central arch. These are in fact solid, but are the obvious types from which the Gujarat minarets are derived (isolated minnārs, for example the Quṭb Mīnār at Delhi, are not unknown elsewhere in India, but the Gujarat mosques present their first systematic use). Other buildings of this first phase of Gujarat building are to be found at Mangrol and Petlad.

A second phase in the history of Gujarat Islamic architecture is represented by the buildings of Ahmad Shāh I in his new capital at Ahmadabad (Ahmedabad), although even there the earliest buildings, Ahmad Shāh's first mosque and the mosque of Haybat Khān, follow the pattern of the Jāmi 'Masjid at Cambay; but soon after them the mosque of Sayyid 'Ālam, of 814/1412, shows several elements which are developed and perfected in the later Ahmadabad buildings, including heavy projecting cornices, well-built and projecting bases for the minarets with internal stairs (the tops of the minarets above the parapet level of the roof have fallen), and an elevated portion of the roof forming a clerestory to admit more light to the central chamber. Ahmad's chef d'cuvre is his Jāmi' Masjid of ten years later. The western lìwān has its 
central chamber flanked by a bay on each side raised above the level of the more distant bays of the western façade by a clerestory roof supported on an open colonnade, the central chamber itself having a second such clerestory carrying the main dome; the light thereby admitted to the central chamber has first to pass through carved stone screens, which are another typical feature of Gujarat architecture. The side riwāqs are all of the simple pillared construction without arches. This mosque, with Aḥmad Shāh's own tomb and a screened enclosure containing the tombs of the queens, form part of Ahmad Shāh's careful town planning, all lying on a central royal way to his palace, on which stands a triple-arched triumphal gateway. All these buildings are in the same harmonious style, which was continued in Ahmadabad under his immediate successors, Muhammad and Quṭb al-Dīn Aḥmad. Muhammad's reign saw the beginning of building at Sarkhej, on the outskirts of Ahmadabad, with the mosque and tomb of Shaykh Ahmad Khattun, the former a vast hypostyle hall with an enormous courtyard, the latter a large square building with arches on all sides filled with stone screens, the central tomb-chamber itself being further surrounded by pierced brass screens. This Gujarat practice of using perforated screens round a tomb-chamber is imitated in later periods in remoter parts of India. Two buildings of Quṭb al-Dīn Ahmad's time are in sharp contrast to other local architecture, the tomb of Daryā Khān in Ahmadabad and Alif Khān's mosque at Dholka; both are in brick, with arches throughout on heavy piers, with none of the usual Gujarat ornament, and seem to have been built by foreign workmen. They are isolated specimens and had no influence on the local style.

A third stage in Gujarat architecture appears in and after the time of Mahmūd I 'Begrā', from the middle of the 15th century. The mausoleum of Sayyid 'Uthmān in a village across the river from Ahmadabad shows in the tomb a greater competence in handling the dome, which is carried by pillars in the form of a dodecagon, than previous examples; and the attached mosque, which is entirely of the open-faced trabeate variety, shows minarets for the first time in this type of mosque, placed at the two ends of the prayer-hall. The arcuate mosques of this time, those of Miyān Khān Chishtī of 860/1456 and Bībī Acht Kūkī of 876/1472, show the minarets still centrally placed, flanking the middle bay of the prayer-hall - but by now rather over-elaborate and dominating the structure. An innovation is a type of oriel window, carried on brackets and fitted with a perforated stone screen, set in the tiw wan façade. The Shāh 'Ālam mausoleum, of 880/1475, shows an increased use of the 
arch in tomb-buildings, again with outer and inner perforated screens. Some five years later the tomb of Quṭb al-'Ālam, at Vāṭā, $10 \mathrm{~km}$. to the south of Ahmadabad, is not only arcuate throughout but of two storeys; but there are irregularities in the construction, as though the builders were still experimenting with the arch as a structural device. The defects have been remedied in the tomb of Sayyid Mubārak (889/1485) at Mahmudabad, where perhaps an architect from outside Gujarat was concerned, for the parapet and the clerestory roof bear chhatrīs similar to those of the Lōdī buildings in Delhi; but the Gujarati feature of the pierced screens round the tomb-chamber continues. Chhatrīs also appear over the entrance porch of the Jāmi 'Masjid in Mahmūd's new city at Champaner. This mosque is very similar in plan to the Jāmi Masjid built at Ahmadabad one hundred years earlier, and has a similar double clerestory; but the decoration is richer, particularly externally: the rear wall of the tīwān shows seven mihrāab buttresses of design similar to the bases of the minarrs, and the four corners bear straight octagonal towers resembling small minārs without balconies; the oriel windows carried on rich corbels add to the exterior richness, as do the smaller pierced screens in every opening. Other mosques in Champaner are of similar design but smaller and with only a small central clerestory; in particular the Nagīna Masjid, which has panels of carved tracery at the bases of the minarrs in the form of intertwining plants. Other works of the time of Mahmūd include his palaces at Sarkhej and his own tomb there by a lake - which has, in addition to various pavilions, a set of sluices carved with the same attention to detail as the minnars of Gujarat mosques - and other buildings at Ahmadabad, of which the mosque of Muhāfiz Khān, farejdār of the city, is the finest; this is an example of the arcuate style of mosque with the minarrs at the ends of the liweran. Towards the end of Mahmūd's long reign the tomb and mosque of Rānī Sabarī shows the usual decorative, almost jewel-like, ornament and tracery to its best advantage by being built on a smaller scale than most of the buildings so far considered; but here the mosque minarets have ceased to be functional, becoming merely slim tapering pinnacles. Other outstanding works, of a different class, are two step-wells (Guj. vāo).

The common Ahmadabad mosque style, with arcuate tìwän and central minārs, is continued by buildings towards the close of the Gujarat Sultanate, for example Rānī Rūpāvatī's mosque of c. 921/1515. One late example, from 980/1572-3, the year before Akbar's conquest of Gujarat, is an exquisite mosque built by Shaykh Sa î̀ al-Habshī, the 
tympana of the arches on the western side filled with stone traceries of filigree-like delicacy, representing palm-trees and creepers, the finest in the Muslim world, of which perhaps the blind traceries of the Nagina Masjid at Champaner are the immediate ancestor.

After the Mughal conquest it would appear that many of the skilled craftsmen were taken by Akbar to North India; certainly there are many features of Gujarati workmanship in Akbar's Fatehpur Sikri.

\section{Malwa}

In contrast to Gujarat, the contiguous province of Malwa was comparatively uninfluenced by a prior Hindu artistic tradition. There were certainly temples, for the earliest buildings, at the end of the 14th and beginning of the 15th centuries, are built of temple spoil. These are three mosques at Dhar, all of trabeate construction; but the portico of the Jāmi 'Masjid shows an interesting attempt to interpose pointed arches between the columns, without any structural significance. The two earliest mosques at Mandu, Dilāwar Khān's of 808/1405-6 and Malik Mughīth's of 835/1432, have similar liwwans, but the latter is raised on a high basement in which there is a range of arched cells; here the pillars of the tiw wan have some pointed arches interposed, as at Dhar, but also with the resulting spandrels filled in with plate tracery. The liwwan is domed, but the phase of transition is crudely effected by lintels and their octagon bases are irregular. There are two domed turrets at the angles of the east (entrance) walls; these, and the shape of the tìwān domes, recall those of Fìrūz Tughluq's time in Delhi. This second mosque is of the time of Hūshang Shāh, whose own complex of buildings dominates the centre of Mandu: the Jāmi` Masjid, the madrasa (later nicknamed Ashrafì Mahall), and his own tomb. The mosque is built on a tall $(4.5 \mathrm{~m}$.) plinth, with arched cells on either side of the entrance porch; these and a few open arches, at courtyard level, perhaps originally filled with screens, and two restrained stringcourses, are the only external decoration, except for a band of merlon-like decoration, of a type already noticed at Delhi, above the chhajja. The liwwan and side aisles are built entirely of true arches on plain slender columns. The mihräb arches show the spearhead fringe, recalling the Delhi Khaljī style, and the minbar is covered by a large stone canopy of obvious Hindu temple design. Hūshang's tomb, a little earlier (the mosque was completed by Mahmūd I in 858/1454), is a square domed 
structure of white marble throughout (the earliest building to be so treated) except for sparing ornament of deep blue glazed tiles, standing in a large enclosure. At each corner of the dome is an engaged domed turret, a common feature in the Mandu tombs and already present over the entrance to the Jāmi 'Masjid. The domes are characteristic of Malwa - a tall cylindrical drum carries the haunch without any intervening structure or decoration, while above the haunch the dome may be developed as a hemisphere or smaller spherical section or as a shallow cone. Later buildings at Mandu become elegant, and in the final stages even meretricious: palaces, pavilions, fountains and waterchannels, kiosks and balconies. The open chhatri appears, and some of the domes are ribbed. In one building, known now as Gadā Shāh's house, there are the remains of some wall-paintings.

A northern manifestation of the Malwa style is found at Chanderi, where the Jāmi' Masjid shows the characteristic stilted domes; the convoluted brackets supporting the chhajja are a somewhat exaggerated form of a type seen in Mandu as early as Hūshang's tomb, a form which becomes exaggerated and elaborated further in Fatehpur Sikri.

The general characteristics of the Malwa style are, in addition to the stilted dome, the fine masonry ofwalls and doors, very restrained ornament, and the frequent use of engaged domical turrets round a central dome. The min $\bar{a} r$, so prominent in the neighbouring provinces of Gujarat and Khandesh, is not used.

\section{KHANDESH}

This small province had a building art with a character of its own, although the mixed origins of that art are to be found in the neighbouring provinces of Gujarat, Malwa, and the Deccan. The Fārūqī khāns ruled first from Thalner and later from Burhanpur, and their buildings are mostly at these two places and at Asirgarh and Chikalda. The Thalner tombs are not dissimilar to the typical square Mandu mausolea in general plan, but the dome is usually carried on a separate octagonal drum, and over the wide chhajj $\bar{a}$ there is a high decorated parapet; the door and window openings are better spaced than in the Mandu examples, and there is more external decoration. An octagonal tomb is covered with fine basso-relievo carving in geometric patterns, and its arches bear on the intrados the spearhead fringe. All these tombs date from the first half of the 15th century. Little remains of the palace at 
Thalner and the Bādshāhī Qil'a at Burhanpur, and the next significant buildings are two late 16th century mosques at Burhanpur. The Jāmi` Masjid has an arcaded façade with minārs at the ends, while the Bībī kī Masjid has two heavy minnars flanking the central arch as in the Champaner mosque in Gujarat; the design of these minārs, however, is original: from octagonal bases they pass to a hexadecagon, above which is a circular storey with oriel windows facing each cardinal point, with a hemispherical dome forming a fourth stage; balconies on heavy brackets separate these four stages. The Jāmi ' Masjid at Asirgarh, although built after the Mughal conquest, perpetuates the Gujarati tradition. At Chikalda an enormous gateway (Barā Darwāza) has an arch of the wide Gulbarga style but is decorated with the lion-and-elephant motif of the Gond kings ( $c$. similar devices at Gawilgarh).

\section{The Degcan}

The principal phases of Deccani architecture, that coinciding with the Bahmanī Sultanate, are to be found at Gulbarga and Bidar, although the kingdom was early provided with a powerful system of fortifications and many of the Bahmanī strongholds contain important buildings.

The Jāmi' Masjid in the old citadel of Gulbarga, although of a type not reproduced later, since its șahn is completely roofed over, shows nevertheless some features that were to characterize Bahmanī architecture and to spread some of the styles of the successor sultanates of the Deccan. The arches of the outer arcade are specially noteworthy: of obtuse angle at the apex, of wide span, and springing from very low imposts. An earlier mosque in the city is a mere compilation of temple spoil, as are the two early mosques at Bijapur built by the Bahmani governors. The earliest group of tombs at Gulbarga, all of the second half of the 14th century, are similar to contemporary examples at Delhi with weak semi-circular domes and battering walls. A later group of tombs, the Haft Gunbad, shows similar sloping walls and domes, but with a refinement of decoration. The outer faces are divided into two apparent storeys with blind arches in each, these arches being of the type which comes to typify the Bahmanī style, stilted above the haunch with straight tangential projections to the apex. Some of these tombs are double -i.e., there are two tomb-chambers with continuous walls but separate domes, standing on a common plinth - and show a few features of Hindu decoration. The tomb of Gīsū Darāz, built after the 
transfer of the court to Bidar, is a single square building with upright sides but otherwise similar to the other Gulbarga tombs. At Bidar the early Tughluq influence has been added to by features of Persian inspiration: thus the early royal palace, the Takht Mahall, while retaining the Bahmani arch, was profusely decorated with encaustic tiles, including a tiger-and-rising-sun device. The foreign element is most pronounced in the madrasa of Maḥmūd Gāwān of 877/1472, which has a prototype in the madrasa of Khargird in Khurāsān; its internal façades surrounding a central courtyard show a single arch of the height of the building on each of the three-storeyed sides, the Persian aywān pattern. The circular miñar is also of a Persian pattern, as is a detached miñar built c. 840/1437 at Daulatabad. The entire surface of the madrasa is covered with multicoloured tiles. The royal tombs at Bidar, ranging over a period of some 80 years from the first example of 839/1436, show the progress of the Bahmanī style. The stilted arches are in general retained, although one tomb unusually shows arches struck from four centres rather like the Mughal arch of North India or the English Tudor arch. Some of the tilework of these tombs is superb, and includes some historically and hagiographically important inscriptions. The domes progress from a hemispherical type stilted over an octagonal drum to a type which, being greater than a hemisphere, shows a tendency towards the bulbous pattern which develops in some of the successor sultanates, and the parapets progress from a line of shield-shaped merlons to a line of stone trefoils. All these tombs have a single entrance doorway, the other sides being either solid or closed by screens, with mihräbs in the western walls; none of them has turrets or chhatris in addition to the central dome.

The Niz̄ām Shāhīs of Ahmadnagar in the western Deccan, although independent there from the beginning of the 16th century until the Mughal conquest, evolved no distinctive architectural style of their own but perpetuated something like the middle Bahmani style with decorative borrowings from Hindu art (and later from the style of Bijapur). Nor was the 'Imād Shāhī style of Berar in the northern Deccan significantly different from its Bahmani parent, except for the use in the mosque façades of a pylon at each end of the tiw $w \bar{a} n$ bearing a square chhatri with deep eaves, heavy brackets, and stone screens in each side, as at Gawilgarh, also Elichpur and Narnala. The buildings of the Barīd Shāhīs, however, the successors of the Bahmanīs in Bidar, do show some notable independent characteristics. The typical Bahmanī stilted arch continues, but the dome becomes even more bulbous, 
usually three-quarters of a sphere. A frequent tomb-pattern is a square domed cell with an open arch on all four faces; thus, since there is no integral mihrāb, a small mosque is built beside the tomb. The trefoil parapet is commonly used. A common feature of the decoration is a chain-and-pendant motif in plaster, but good tilework is still a frequent ornament. The latest buildings tend to become over-ornate, and the influence of the Hindu mason becomes more apparent.

The style of the 'Ádil Shāhī buildings at Bijapur in Karnataka is the most developed and the most original of the Deccani Sultanates. The earliest dated 'Ādil Shāhī building, a mosque of 918/1512-3, already shows features which characterize this style throughout: the base of the dome surrounded by a ring of vertical foliations, so that the dome resembles a bud surrounded by petals; and a three-arched façade in which the central arch is much wider than the flanking arches. Another early mosque reveals another Bijapur speciality in its arch spandrels, a medallion supported by a bracket-shaped device, moulded in plaster. The works executed before the death of 'Alī I in 987/1579 are mostly in rubble covered with dense and durable plaster, and include the city walls and gates (most of these with the typical wide centre arch flanked by two narrow ones), many palaces and audience halls, and some notable mosques. One of these, in memory of the sayyid 'Alī Shahīd Pīr, which unusually has a transverse wagon-vaulted roof, shows the (equal) façade arches surrounded by an outer band of cusping, remarkably similar to that of the recently-discovered Jurjīr mosque in Isfahan. This device recurs in the other buildings, for example the Jāmi 'Masjid of 985/1576, where it decorates only the central arch of seven, which also bears the medallion-and-bracket device; the great dome of this mosque is supported by an original system of vaulting by which two intersecting squares, both oblique to the square chamber underneath, form an octagon; this system is later used to great effect in the colossal mausoleum of Muhammad 'Ādil Shāh. This mosque also shows a feature made much of by later Bijapur builders, an elegant exterior. The domes in this early phase are hemispherical; minārs are not used, although bases for them exist in the Jāmi' Masjid; small ornamental pinnacles (guldasta), however, are freely used at angles of the parapets and over mihrāb buttresses, of a type found on some of the Bahmani tombs at Bidar.

After 987/1579, under Ibrāhīm II 'Ādil Shāh and later sulțāns of Bijapur, fine sculptured stonework replaces the earlier rubble-and-plaster. The dome becomes a three-quarter sphere; the cornices and eaves are 
supported by intricate carved brackets, often with the added decoration of hanging stone chains and locket-like pendants (is there a connection between these and the chain-and-pendant plaster device of the Barīd Shāhīs?), and the parapets become delicate lace-like borders. But many of the earlier features persist: the band of foliations at the base of the dome, the occasional cusping of a central arch, the medallion-andbracket motif, now often carved in stone, the characteristic wide central and narrow flanking arches, and the love of vertical projections above the sky-line; but these have often become pseudo-minarrs, in that they appear over solid bases and rise at the sides of mosque façades where in other styles true minārs are found, although they are slender and solid and hence can only be decorative; they frequently carry miniature domes, and fascicular clusters of minuscule minarets along their shafts, in each case with the petal-like foliation. The enormous mausoleum of Muhammad (d. 1067/1656), known as the Gol Gunbad, reverts to the hemispherical dome, and has a large staged octagonal turret of the height of the building at each corner; but the prototype of these is the small octagonal pinnacles found in the earliest buildings. In tombs of the closing years of the dynasty, there is a tendency to exaggerate an intermediate stage, a square storey between the parapet of the tombchamber and the drum of the dome, so that in extreme cases the globular dome appears almost separated from the ground floor. While the most characteristic features of the 'Âdil Shāhi style are found in the vast number of buildings at the capital some Bijapur characteristics are encountered further afield, for example in two mosques standing outside Naldurg fort, and at the great entrance arch to the dargāh of Gīsū Darāz at Gulbarga.

The Deccan style of the Quṭb Shāhīs, first in Golkonda and later in the adjacent city of Hyderabad in Andhra Pradesh, is distinctive more on account of its luxuriant ornament than any originality in structure. The principal building material is stone, usually grey granite or trapstone, but rather than being carved this is ornamented with stucco and encaustic tiles. The tombs of the Quṭb Shāhī dynasty at Golkonda, and the mosques and gateways there and at Hyderabad, show the comparative fixedness of the style over a century and a half from the time of Sultān Qulī's independence in 924/1518. The tombs are almost all square in shape and constructionally resemble the Bahmanī tombs in Bidar; the earlier ones are single-storeyed, and only once is the outer face divided into two apparent floors by an upper row of blind arches; some of the later tombs have two storeys, the lower one forming a 
projecting arcade around the building. The domes are all bulbous, usually a three-quarter sphere, and are foliated at their bases in a similar way to the Bijapur domes; but the later buildings develop this into a double or triple band of foliation. The Quṭb Shāhī buildings emphasize especially the upper parts of walls between the eaves and the parapet, and the rich ornament here is sometimes projected out from the façade to form a balcony carried on brackets. The parapets are crenellated with trefoil-shaped merlons, as in the later Bahman̄̄ and Barīd Shāhī styles, and are frequently interrupted by small guldastas; at the corners these may be replaced by small mīnārs. The Quṭb Shāhī mīnār, whether decorative or functional, has its shaft encircled one or more times with an arcaded gallery, and bears a miniature dome with the characteristic foliations. Designs of Hindu provenance are not infrequent in the ornament, especially in the later periods; but these were accepted in the earliest period, as they occurred freely in the Kākatīya work taken over in the old Bahmani province of Warangal - for example, in the Bālā Hiṣār Darwāza at Golkonda.

\section{KASHMIR}

The architecture of Kashmir is remarkably different from that of all other regions of India, as it is essentially in wood: great logs of deodār (Cedrus deodara) laid horizontally and joined by crude carpentry, and used also as piers to support any superstructure; the interstices between courses may be filled with brickwork or plaster covered with glazed tile. There is of course a constant fire risk, and many buildings have undergone repeated rebuilding, usually, however, reproducing the form of the original structure. The typical Kashmiri Muslim building is the tomb-shrine (ziyarat) of a local saint: a cubical ground floor (sometimes set on a stone or brick plinth), covered by a pyramidal roof which may be in several tiers, topped by a long and slender wooden flèche. The same type with flanking courtyards may be used for mosque buildings, with the addition of a square open pavilion between roof and flèche to form a platform for the mu'adhdhin (the minaret is not used). Such a pattern is used in the mosque of Shāh Hamadān in Srinagar, a two-storeyed building on the plinth of a Hindu temple, with projecting wooden balconies and the eaves supported on a log cornice; the pyramidal tiered roof is covered with an impervious layer of birch-bark and then with turves planted liberally with irises and tulips, above which 
rise the ma'dhīna platform and the flèche. The Jāmi' Masjid in Srinagar, dating from the end of the 14th century, but three times rebuilt, is the most ambitious example of pre-Mughal Kashmiri architecture: a vast square courtyard is surrounded on each side by a wide arched wing which carries a central ziyarat-like structure, that on the west having a tall central brick arch. Much of the lower walling is in brick, but the surrounding colonnades are composed entirely of deodār trunks on stone plinths. Some fine stone tombs of the 15th century exist, constructed from temple spoil, but domed and covered with glazed tiles.

\section{SINDH}

The building style of Sindh (Pakistan), while not so conspicuous as that of Kashmir, stands apart from other provincial Indo-Muslim styles since it has many affinities with the building art of eastern Persia, and where Indian motifs appear they often seem to be used with neither organization nor fluency in their use. They are represented especially by the remaining tombs at Thattha, where some building stone was available, although the characteristic medium of the country was brick. The stonework of one of the earliest remaining tombs, that of Jām Niẓām Dīn (d. 915/1509), is in stone which seems to have been carved by Hindu workmen who were not good enough to find work in Gujarat; perhaps they came across the Rajasthan desert with only the memory of the designs, or were the local employees of the Sammās, recent converts to Islam but with rather faded memories of a dilute Hinduism. The carved Arabic inscriptions are in excellent thulth, incongruously set next to bandeaux carved with the geese of Hindu mythology. Other stone tombs are ornamented with shallow and often curiously discontinuous geometrical carving. The brick tombs certainly show a great familiarity with the material; solid dense bricks, after all, were known in Sindh at the time of the prehistoric Mohenjodaro. They are built on stone foundations, to counteract the destroying effects of the high salinity of the Thattha soil, and their surfaces are covered with the tilework for which Sindh is renowned. Common tilework patterns include dark blue rectangles outlined with white, to give the effect of an imitation mortar-joint; the tiles themselves are of hand-baked terracotta, very heavy, and the glazes are generally white, light-blue, turquoise, and dark blue, very occasionally also yellow. Generally the design is continuously worked in multicoloured tiles, but occasionally very small tiles, like tes- 
serae, each of one colour, are built up to form a mosaic. The design of the tombs, especially their domes, and the few remaining mosques, is essentially Persian rather than Indian, although this may be due to early Mughal influence. Certainly some of the Thattha buildings of later times revert to a trabeate style in sandstone, such as the mausoleum of 'İsā Jān Tarkhān the younger, d. 1054/1644, which recalls the buildings of Fatehpur Sikri and also is the only building in which the intrados of the arch is embellished with a spearhead fringe. 


\section{MUGHAL ARCHITECTURE*}

Shortly after Bābur's arrival in India in 932/1526 he ordered buildings to be erected; he was unimpressed with Indian edifices, and disgusted with the lack of the formal gardens to which he was accustomed. Most of his works were, therefore, secular, consisting of terraced gardens with pavilions and summer houses, hardly anything of which has survived. Two of his mosques exist, one in Panipat and one in Sambhal: works large but utterly undistinguished. Little more can be said about the buildings of Humāyūn's reign (except those works of a previous period now completed); but Humāyun's importance is in the craft traditions imported with him after his exile rather than the ideas of his own.

\section{The SūRİ INTERREgnum}

In point of time, the Sūr sulțān Shēr Shāh followed Humāyūn although his buildings are a continuation of pre-Mughal styles. There is, indeed, little characteristic architecture remaining of the first part of Humāyūn's reign from which a comparison might be made, since Shēr Shāh systematically destroyed Humāyūn's city of Delhi called Dīnpanāh. In his tombs at Sasaram in Bihar, Shēr Shāh perfected the octagonal pattern, and may indeed have planned these buildings in the decade before he came to power. The earliest (c. 941/1535) of these, the tomb of his father Hasan Khān, is experimental: there is no plinth, and the drum is a bare wall without fenestration or chhatris. Unlike the Lōdī examples, the Sasaram tombs have vertical, not battered, walls. The next tomb, that of Shēr Shāh himself, is amplified not only from this but also from the Delhi models; it is in five stages, rising to $50 \mathrm{~m}$., and set in the middle of an artificial lake connected to the shore by a causeway to which access is given by a domed guardroom; the lowest stage is a square plinth rising out of the water, the next a vast square platform with a chhatri at each corner, on which stands the octagonal tomb chamber in three further stages, the two lower with chhatris at

\footnotetext{
* "Hind, vii Architecture," EI, III, 448-51.
} 
the corners. The roof is crowned with a massive lotus finial. The tomb of his successor Islām Shāh also stands within a lake, but smaller; the better preservation of its causeway shows this to have been constructed on a cantilever principle, each pier with projecting balconies and carrying a chhatrī. In Narnaul Shēr Shāh built the tomb of his grandfather Ibrāhīm Khān, a square building not unlike the square Lōdī tombs, but finished in better stone and with a shallower dome.

After Shēr Shāh's accession in 947/1540 he started building at Delhi, fortifying first the Purānā Qil'a and adding an exquisite mosque, with the corner turrets already noticed in the Moth ki Masjid and the Jamāli mosque, and with a refined form of the recessed arch: a lower arch set back from a taller one. The arches are struck from four centres, and the spearhead fringe is again in evidence. The stonework is very finely jointed, enriched with fillets of white marble, with fine coloured inlay patterns of a type similar to that later found in Akbar's mosque at Fatehpur Sikri. The interior decoration is similar to that of the Moth kī Masjid, but with every part refined. Other important building products of Shēr Shāh were at Rohtasgarh in Bihar and his new fortress of Rohtas in the Panjab, as well as many single buildings at other towns.

\section{Period of Akbar}

The first major building to be erected during Mughal rule is Humāyūn's mausoleum, not begun until 976/1568-9 in the early years of Akbar's reign, and erected, not in his lifetime after the usual practice, but by his widow. The cenotaph-chamber, which stands on a vast high plinth, is essentially square in plan, with each corner of the square chamfered off and with a recessed central bay in each side. Each of these bays contains a deep arch, as high as the walls on either side of the bay, constructed as a half-dome, and smaller arches of varied height and levels fill the remaining façades of each wall. The central chamber is surmounted by a tall drum, which carries a high double dome, with a chhatri of Lōdī type, open and on slender pillars, at each corner, and two smaller square chhatris over each central arch. The dome is slightly curved at its base, but its general shape echoes that of the arches below; the arches introduce a new shape to North India, as their curves are struck from four centres. The building is in red sandstone with white and grey marble inlay (sparing use of other colours as well), executed 
in star-shaped designs at the drum below the dome, well inlaid but not polished in situ: this inlay work is to be classified as opus sectile rather than as the finely polished marquetry-like pietra dura of later Mughal periods. A smaller tomb of not dissimilar design is that of Akbar's foster-father, Atga Khān, at Niz̄āmuddīn; but Humāyūn's tomb gains enormously in effect not only by the vast plinth (which contains the true tomb immediately below the cenotaph) but by the vaster garden in which it is set - a great square, subdivided into squares and squares again by paths, flower-beds, and parterres. It marks immediately the advent of a new style in India, and is of great importance as the immediate Indian prototype for other monumental mausolea.

Akbar's building projects, many and varied, reflect something of the man. They start at Agra Fort, on the trace of the previous Lōdi fort, with the gateways: a half-octagon flanking tower on each side of the four-centred arch of the gate, the towers decorated with blind arches below and open arches on the upper storey, with chhatris over towers and gateway; internally, the arch carried a spearhead fringe of a more elaborate and conventionalized form than that of previous reigns; the whole is decorated in opus sectile. Palaces inside the fort are in much the same style, and include projecting balconies supported on richly carved corbels, with much beam-and-bracket workmanship; some of the brackets, in sandstone, seem to have been borrowed directly from wood-building techniques. Similar buildings were commenced, in very similar styles, at Lahore and, on a smaller scale, at Allahabad. The new capital, at Fatehpur Sikri, is a sandstone city. The palaces are for the most part built in the trabeate style, with shallow domes and heavy eaves recalling Lōdī work, occasional arches with the spearhead fringe, carved brackets resembling those of Rajasthani temples, and superb carving. There is some inlaid opus sectile work in white marble, especially on the mosque; the inside of the mosque, however, is of finely polished marble mosaic inlay, the first attempt towards the technique of pietra dura. Some buildings in the city, such as the Dīwān-i Khāșs, with an extraordinary bracketed central column supporting a platform in the middle of the single room, and the Pānch Mahall, a five-storeyed pyramidal open pavilion, are unique structures, part of Akbar's personal whimsy, with no significance in the development of the Mughal style; but one of interest and archaeological significance is the tomb of Salīm Chishtī, after 979/1571, a square chamber with an outer verandah which is screened with marble lattices on the outside: a feature characteristic not of North India, but familiar in the tombs 
of Gujarat. The eaves are supported on convoluted brackets which have a prototype in Chanderi. Another Gujarat feature, apparently, is the reservoir which lies beneath the sahn of the great mosque (on these features see J. Burton-Page, Fatehpur Sikri, in R.E. Mortimer Wheeler (ed.), Splendours of the East, London 1965, 143-53).

Of Akbar's reign in Delhi is the last of the octagonal tombs, that of Adham Khān, of 969/1562; it is without the wide chhajjā which characterizes the earlier octagonal tombs, and, being also without chhatris, looks curiously insipid. Of about the same time is the Masjid Khayr al-Manāzil, with a four-centred arched façade, an imposing gateway with opus sectile decoration, and corner turrets at the rear of the liwe $\bar{a}$ n similar to those on the Lōdī Moth kī Masjid and the Sūrī mosque in the Purānā Qil'a. At Jaunpur is a fine bridge, with screened pavilions over each pier, across the river Gumti, and at Gwalior is the tomb of Muhammad Ghaus, which has the typical Gujarati screened arcades.

\section{Period of JAhĀNGīr}

Jahāngīr's interest was more in miniature painting than in architecture, and there are few examples of the buildings of his reign; although it is known that he extended Akbar's buildings at Agra and Lahore Forts, beginning at the latter a "picture wall" in mosaic tiles showing hunting, polo and court scenes, and completed the building of Akbar's tomb: a four-storeyed pyramidal building, over-ornamented with chhatris, with a large half-dome archway in each face, opus sectile ornament, and an open square with a cenotaph, all in marble, at the top, standing in a vast chär-bāgh garden. The entrance gateway is imposing, with a tall white marble minār at each corner - the first appearance of this feature in the north. The two most important buildings of Jahāngīr's reign are the tomb at Agra, begun 1031/1622, of his father-in-law Mīrzā Ghiyāth Beg entitled I'timād ad-Daula, in marble inlaid in Persian motifs (cypresses, vines, flowers, vases, wine-cups) in true pietra dura, with four short corner towers, and fine marble tracery screens; and the tomb of 'Abd al-Rahīm Khān-i Khānān, similar to that of Humāyūn's tomb but without the corner chambers. The former tomb heralds the decorative techniques of the Tāj Mahall; the latter is the immediate prototype of its design. 


\section{Period of ShĀHJAhĀN}

The buildings of Shāhjahān show the Mughal style at its height, although the earliest, the completion by Nūrjahān of Jahāngīr's tomb at Shāhdara, near Lahore, continues the opus sectile tradition; it is of only a single storey, with a lofty minarr at each corner, again in an immense garden; it is more important for its decoration than for its structure, not only on the surface of the building, but in the pietra dura of the cenotaph, in white marble, calligraphy (the 99 names of God) appearing in delicate pietra dura here for the first time. Shāhjahān himself replanned the buildings at Agra and Lahore Forts, replacing some of the earlier sandstone structures with marble ones; these are characterized by engrailed arches, tapering supporting columns and pietra dura ornament, especially on walls and at the feet of columns and their plinths; and the marble was delicately channelled and carved. There appear at Agra, for the first time in North India, two oblong pavilions with a Bengali-style curved cornice to the roof; and at Lahore Fort also is a pavilion in the style of a Bengali chau-chala hut. These works were perhaps a preliminary essay for Shāhjahān's own grandiose fort, the Lāl Qil'a (from its red sandstone enclosure walls) in his new city at Delhi called Shāhjahānābād. The palace buildings are distinguished for their symmetrical planning along an ornamental marble canal, with chutes and cascades; in structure they are similar to those at Agra, except that the columns tend to be thicker, and the pietra dura work and the marble carving are of the highest quality.

Before the fort was begun, however, the construction of the mausoleum of his queen, Mumtāz-i Mahall, had been started. This building, known to everyone by its corrupted title of Tāj Mahall, is in the suburb of Agra now called Tājganj on the bank of the Yamuna river: a complex of buildings with a square mausoleum with a tall miñar at each corner of its plinth, and a red sandstone mosque and an identical jawāb, used as a mihmān-khāna, flanking it on a platform at the river end of the great oblong garden; the garden divided by paths and parterres, with central crossing water-channels, and an imposing gateway. The entire mausoleum, plinth, and the four minārs are worked in white marble with pietra dura in semi-precious stones, and there is a tall white marble dome, surrounded by four marble chhatris; the dome is slightly bulbous. This is the perfect culmination of the tomb-type starting with Humāyūn's tomb of a century earlier, through 'Abd al-Rahīm Khān-i Khānān's 
tomb, with decoration of the type started in the tomb of I'timād adDaula and perfected at the forts of Agra, Lahore and Shāhjahānābād. In Delhi the plans for the city were completed with the Jāmi ${ }^{`}$ Masjid, 1057-9/1648-50; the tiw wan, in red sandstone with white marbles, has a large central half-dome arch, with five smaller flanking arches on each side, all engrailed; two minārs at the courtyard ends of the lizwain; and three bulbous marble domes. A similar mosque, much smaller, was built in Agra at about the same time for his daughter Jahān Ārā; here the arches revert to the plain (not engrailed) four-centred type. Another important building of Shāhjahān's reign, of a different type, is the mosque of Wazīr Khān in Lahore, of c. 1044/1634; here the ornament is more akin to the arts developed in Persia, consisting of true mosaic tile decoration on the external surfaces, floral, calligraphic, geometrical, especially with the cypress (sarv) and the plane (chunarr); the internal surfaces are painted in tempera and cut-plaster. Other buildings of Shāhjahān are at Ajmer (two marble lakeside pavilions) and Kashmir (terraces in the Shālimār gardens, laid out by Jahāngīr).

\section{Period of AurangzīB}

In the reign of Aurangzīb the building art began to lose its vitality, although the Mōtī (pearl) Masjid he added to the fort of Shāhjahānābād, c. 1070/1660, retains the delicacy of earlier craftsmanship (the too-large bulbous domes are a later addition). The effeteness is starting to be apparent in the great Bādshāhī Masjid of c. 1085/1674 added to the west of Lahore Fort, with four tall minārs at the corners of the courtyard, four short ones at the corners of the tiwwan; the three domes are a little over-bulbous, and the tīwan façade presents too many blank spaces. A few years later the tomb of Aurangzīb's wife, Rābi'a Daurānī, was built at Aurangabad; it stands in a walled garden, which is its best feature; for it is a half-scale copy of the Tāj Māhall, with a thin engrailed central arch, bulbous dome, disproportionately heavy minnars, a cramped skyline with insufficient room for the corner chhatris, attenuated guldastas, which combine to give it an air of assiduous mediocrity. Aurangzīb's mosques at Banaras (Varanasi) and Mathura, on the other hand, are orthodox and well-proportioned, so it must be assumed that he played no personal part in their construction. A far better tomb building is the last of the great square mausolea, the tomb of the wazir Safdar Jang at Delhi (d. 1166/1753), of good proportions, even if the dome 
is a little too bulbous, in finely worked fawn sandstone, and in the last great chār-bāgh garden.

\section{Post-Mughal styles}

The Nawwābs of Awadh, in their capital of Lucknow, became the artistic successors to the Mughals. Their earlier buildings are similar to the Aurangzībi buildings, large and impressive, but over-decorated; their later ones, produced in a sort of bastard château style under the influence of a French adventurer with magnificent vision and no taste, mixed up with Corinthian capitals, fluted domes, compositions of round romanesque arches, ogee arcades, and odd ideas gathered from the Mughals, Ancient Greeks, and the European "Palladian" school. The Sikh style of the Panjab is at least of consistent late-Mughal extraction, but tends to over-proliferated chhatris and the fluted dome, and to be too partial to the Bengali cornice. Some of the Rājpūt palaces have preserved better elements of late Mughal style, especially at Amber and Jaipur, and have combined it with an excellent masonry technique.

In the south a strange hybrid Islamo-Vijayanagara style was evolved at Hampi, and later scions of the Vijayanagara house, after the dissolution of their empire, remembered in some elements in their palace of Chandragiri. The few buildings of the Mysore Sultanate of Haydar 'Alī and his son Tipū are less bizarre, particularly the tomb of the dynasty at Srirangapattana. Other local Muslim styles are more aberrant: for example, the 19th century tombs at Junagadh in Gujarat, which appear to translate the fancy knobs of a Victorian bedstead into stone, not without skill. 


\section{INSCRIPTIONS*}

The Indian sub-continent is very rich in Muslim inscriptions, the study of which affords valuable information not only to the archaeologist and historian but also to the geographer, the economist, the student of religions, the linguist, and of course the calligrapher. Most of them are found on religious buildings (tombs, mosques, ìdgāhs, imāmbārās, madrasas) and military works (forts, gates, bastions, cavaliers, towers), or on works of public utility (bridges, tanks, $b \bar{a}$ o $h \bar{\imath} \mathrm{s}$, dams, sluices, sara $\bar{\imath} \bar{\imath}$ ); some are also found on palaces, gardens, pavilions, etc.; and another class is found on movable objects such as guns and swords, ornamental metalwork including bìdri ware, and on crystal and jade. The greatest part of the public inscriptions is carved on stone; often of a stone identical to that of the main building material, but not infrequently a specially selected fine-grained stone is used for the inscription and cemented into the structure.

Here the question of authenticity must be considered. An inscription may indeed be exactly contemporary with the building on which it appears. But it may also be earlier, preserved through the reverence accorded to the written word or through the ascription to it of some special sanctity, and set into a later unrelated building; or else later, marking say the completion of a building project essentially constructed perhaps half-a-century earlier, as at the Jāmi' Masjid of Bijapur, a late 'Ādil Shāhī building whose inscription records its completion by Aurangzīb; or recording a restoration (as in many works in Delhi of Fīrūz b. Rajab, whose inscriptions have to be studied in connection with the problems of interpretation in his own accounts of his restorations in the Futūhăt-i Fìnūz-Shāhñ); or it may be fictitious - not necessarily mischievously: for example, the Persian inscription of the Masjid Quwwat al-Islām at Delhi is probably a pia fraus of 60 or 70 years after the conquest.

The technique of carving stone inscriptions in Arabic, Persian or Urdū is conspicuously different from that of inscriptions in other Indian languages, where the characters are engraved into the surface of the

\footnotetext{
* "Kitābāt," EI, VI, 231-3.
} 
stone; in the Muslim inscriptions the outline of the letters is first written on the stone, and the ground between the letters then chiselled away leaving the inscription level with the original surface. A similar technique may be applied to inscriptions on crystal and jade, and also to the larger metal pieces, although on any of these fields the letters may be incised and the grooves filled with another material to leave an inscription flush with the surface; in the case of $b \bar{\imath} d r \bar{\imath}$ ware this is regularly of silver bar laid into the base metal. Inscriptions in ceramics may be either of letters in a contrasting colour fired integrally in a regularly-shaped tile (haft-rang $\bar{\imath}$ ), or consist of the individual letter-shapes let into a contrasting ground by a mosaic technique. The former ceramic technique is more commonly employed for simple repetitive motifs (e.g. the names Allāh or Muhammad), sometimes combined with a moulded base on which the letter-shapes are raised, as on the merlons of Rukn-i 'Ālam's tomb in Multan (Pakistan); mosaic tile inscriptions, which do not appear until the 17th century, are best exemplified in the Mughal buildings of Lahore (Pakistan).

The language of the earliest inscriptions is invariably Arabic. There are no inscriptional records of the 'Abbāsid presence in Sindh, although a few were engendered by the Muslim communities which lingered on in Sindh and the Panjab, with their occasional offshoots to Kutch and the north coast of Kathiawar in Gujarat, to which were added the small communities which grew up around the khānqāhs of individual Șūfí saints who drifted in to India before the Ghūrid conquest, especially in the Panjab and the Ganga valley. After the Ghūrid conquest of Delhi, dating inscriptions remain in Arabic regularly until towards the end of the 13th century, when they are replaced by Persian; non-historical epigraphs tend to remain in Arabic somewhat longer, and of course Arabic persists up to the present day for Qur'annic quotations on mosque and tomb inscriptions. This does not, however, apply to the sultanates of Bengal, where the preferred language of dating inscriptions remains in Arabic until Mughal times. In late Mughal times, in North India, Urdū inscriptions appear beside Persian. Away from Delhi, there are many bilingual and trilingual inscriptions, especially in the Deccan (Persian/Sanskrit, Persian/Marāthī, Persian/Kannada, etc.); there are a few inscriptions in the Deccan regions in Dakhnī. Not infrequently the date is written in Arabic words in a Persian inscription; and often the Arabic, and to a less extent the Persian, is grammatically incorrect. The date in North Indian inscriptions is regularly expressed in Hijrī years, except for a few inscriptions of the time of Akbar and Jahāngīr which 
use the Dīn-i Ilāhī system, or are dated by regnal years. In the Deccan, various solar calendars are occasionally used, especially the Shuhür san in the 'Ādil Shāhī Sultanate of Bijapur, and a Faṣlī san in Golkonda and under the Nizāms of Hyderabad. In Mysore under Haydar 'Alī and Tipū Sulțān, the Maudūdī era is used.

The scripts in use are the common Kūfic, naskh, thuluth, and nasta tìq. Küfic is used only in the earliest dating inscriptions, and retained long after its period of active use in Qur'ānic quotations. Naskh and thuluth are in common use for both Arabic and Persian inscriptions all over India, with some regional modifications. Nastatì is regularly used for Persian inscriptions in and after the Mughal period, and for inscriptions in Urdū. Of the regional styles, the most striking is that of Bengal, where the vertical strokes of alif, kā $f$ and läm are much elongated and spaced evenly across the length of the inscription, leaving the significant parts of the remainder of the letters to occupy the lowest quarter or third of the band; sometimes the tails of final or detached $n \bar{u} n$ or $y \bar{a}^{\text {' }}$ are so disposed in the top part of the inscription to produce the "bow and arrow" effect. A similar style is seen also on some of the coins of Jaunpur. Elaborate tughrās fall more in the domain of farmāns and other such documents rather than in public epigraphs, although they are certainly known in ceramic tile inlay and in pietra dura in Mughal buildings; but simpler tughrās, in the square seal-script, are not uncommon, consisting usually of repetitions of the names Muhammad or 'Alī, or both, or the kalima. None of these seal-script inscriptions approaches the complexity of the Iranian examples. Simple dating inscriptions are usually unadorned; but many mosque inscriptions, starting with the maqșüra arches of the first stage of the Masjid Quwwat al-Islām in Delhi, are engraved against an arabesque pattern also carried in relief on the ground. The finest example of this, however, is a dating inscription of the governor Tughril from a lost building at Bihar Sharif. Similar arabesque patterns may also set off inscriptions in tilework or painted plaster, and occur also on coins of the Mughal period. Many inscriptions are of a high order of calligraphic excellence, and the names of many calligraphers in many regions of India are recorded.

The information which the inscriptions provide for the historian is sometimes very valuable; at times, they furnish the only sources for doubtful points of dynastic chronology; they supply missing details from the literary histories, or enable confusing points to be resolved where the other documents are in conflict; they enable more complete lists to be made of rulers' families, of the local nobility or court and town 
officials; and they are a valuable source of information on the history of the buildings on which they are found (subject to the reservation on their authenticity referred to above). Indirectly, too, their location enables the political status of border regions at certain confused times to be determined, such as the regions in dispute between the Malwa and Jaunpur Sultanates, or the Raichur $\bar{D}^{\prime} \bar{a} b$; in many cases, an inscription is the only evidence for a fort or stronghold having been occupied by a particular power at any time. Even when rulers and governors are known from chronicles, the inscriptions often provide essential information on details of their careers, their promotions and postings, their achievements, even on their families. Tomb-inscriptions frequently mention their subject's birthplace, and thereby provide evidence for the extent of immigration and for the settlement pattern of foreign groups.

Administrative and economic details contained in or implied by the inscriptions can also be invaluable: information on details of departments, names of offices, and designations of office-holders; on the imposition or remission of taxes, and their varied application to certain classes or trades; on the nature and conditions of grants of land, both to holders of an $i q t \bar{a}^{`}$ and to charitable institutions such as mosque or madrasa as waqf; on land cultivation or irrigation (well inscriptions, or records of repairs to tanks and dams, often refer to the amount of land intended to be irrigated); on regional boundaries; on markets. Records on works of public utility may include a schedule of expenses or the wages to be paid to employees. Geographical details, including distances, occur in inscriptions relating to roads and bridges, which also provide information on their builders - besides recording the correct forms of place-names, which seem singularly liable to corruption by copyists of the chronicles. Building inscriptions often indicate the cost of construction as well as details of the architects; an unusual inscription in the tomb of Hūshang Shāh at Mandu records a tribute by visiting Mughal architects of the family of master-builders who were later responsible for the Tāj Mahall. Gun inscriptions, as well as prescribing essential instructions on the quantity of charge and shot required, frequently provide information on gun founding and the gun-founders - often Turks or Europeans - involved in the industry.

The literary contribution of the inscriptions must not be overlooked. Many inscriptions are in verses composed ad hoc, some of considerable beauty and skill; but it must be admitted that the verse of a lot of inscriptions is no better than doggerel. This is especially the case 
with verses containing a chronogram, where taste is often sacrified in favour of ingenuity. There are occasional quotations from well-known Persian poets, but frequently the authors are local poets not otherwise recorded. Specimens of Dakhnī poetry are preserved in some Deccan inscriptions. Some prose inscriptions also evince literary merit, and may contain traditions not found in the usual collections of ahädith, such as the saying ascribed to Jesus in the Jāmi` Masjid of Fatehpur Sikri (Persian), or the variations on a tradition (Arabic) in the mosque inscriptions of Bengal, basically: "The Prophet, God's peace be upon him, said 'He who builds a mosque to God, for him God builds a qașr in Paradise"". Sentiments expressed range from strict and self-conscious rectitude through quietist mysticism to wistful nostalgia.

There is also the linguistic contribution of inscriptions. The occurrence of local words (Hindī, Bengali, Marāthī, Gujarātī, Urdū and Dakhnī in particular) is useful in reconstructing the history (and social conditions of use) of Indian languages. Bilingual inscriptions provide evidence on the extent of use of local languages and their place in communication of official instructions to the public, and the status of a particular local language in a border area; this is especially the case in the Deccan, where Muslim inscriptions in Kannada, Marāthī and Telugu are not uncommon besides the usual Persian and Dakhnī.

The Indian sub-continent has been fortunate in the attention which has been paid to Muslim inscriptions for well over a century. Hundreds are recorded in orientalist publications, besides those in specialist journals devoted to epigraphy alone; and India has been well served by highly competent Government Epigraphists appointed specially to oversee Arabic and Persian inscriptions, of whom Ghulam Yazdani and Ziyauddin A. Desai were preeminent. The work of exploration, interpretation and publication is still active.

\section{Bibliographic Note}

In the 19th century epigraphs were mostly published, usually with translations and notes, in $\mathcal{F} A S B$. From 1907 the invaluable EIM appeared, which continuted until 1947. Pre-EIM inscriptions are listed in J. Horovitz, A list of the published Mohamedan inscriptions of India, in EIM (1909-10). Since the cessation of EIM, Muslim inscriptions of India have appeared in EIAPS, and valuable comments are also found in $A R$ $I E$. Articles and studies are recorded in K.A.C. Creswell, $A$ bibliography, 
and its Supplements. Many of the earlier EIM articles collect the epigraphs of individual sultāns, but recent discoveries have rendered many of these out of date. V.S. Bendrey, A Study of Muslim inscriptions, Bombay 1944, extracts some historical information from epigraphs published in EIM to that date. But since the author knew no Arabic or Persian many significant details were not appreciated and the work suffers from the limitations of its corpus. More recently, two valuable compendia have been brought out by Ziyauddin A. Desai: see Bibliography [editor]. 


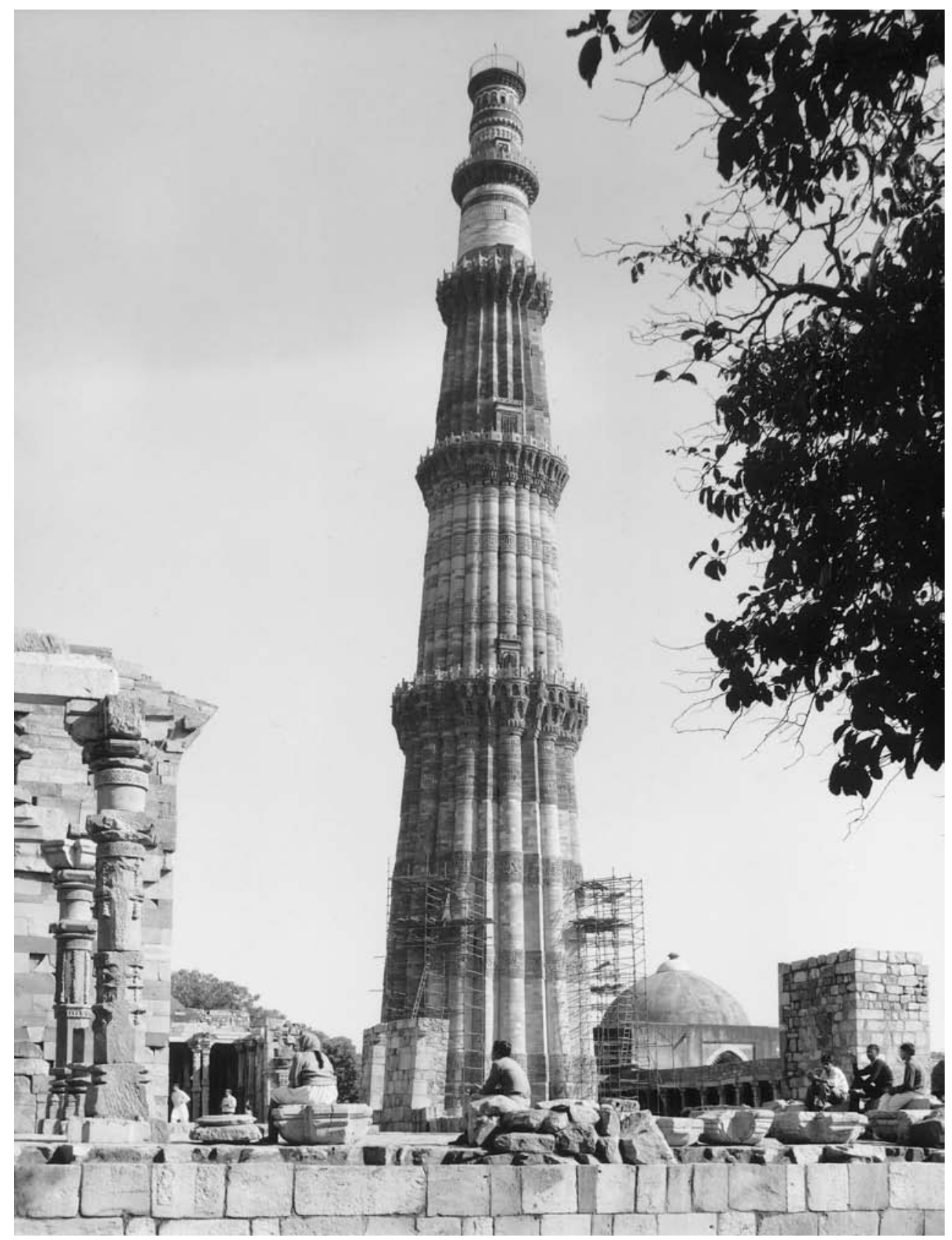

1 Delhi, Quṭb Mīnār, 595-634/1199-1236. (Courtesy American Institute of Indian Studies) 


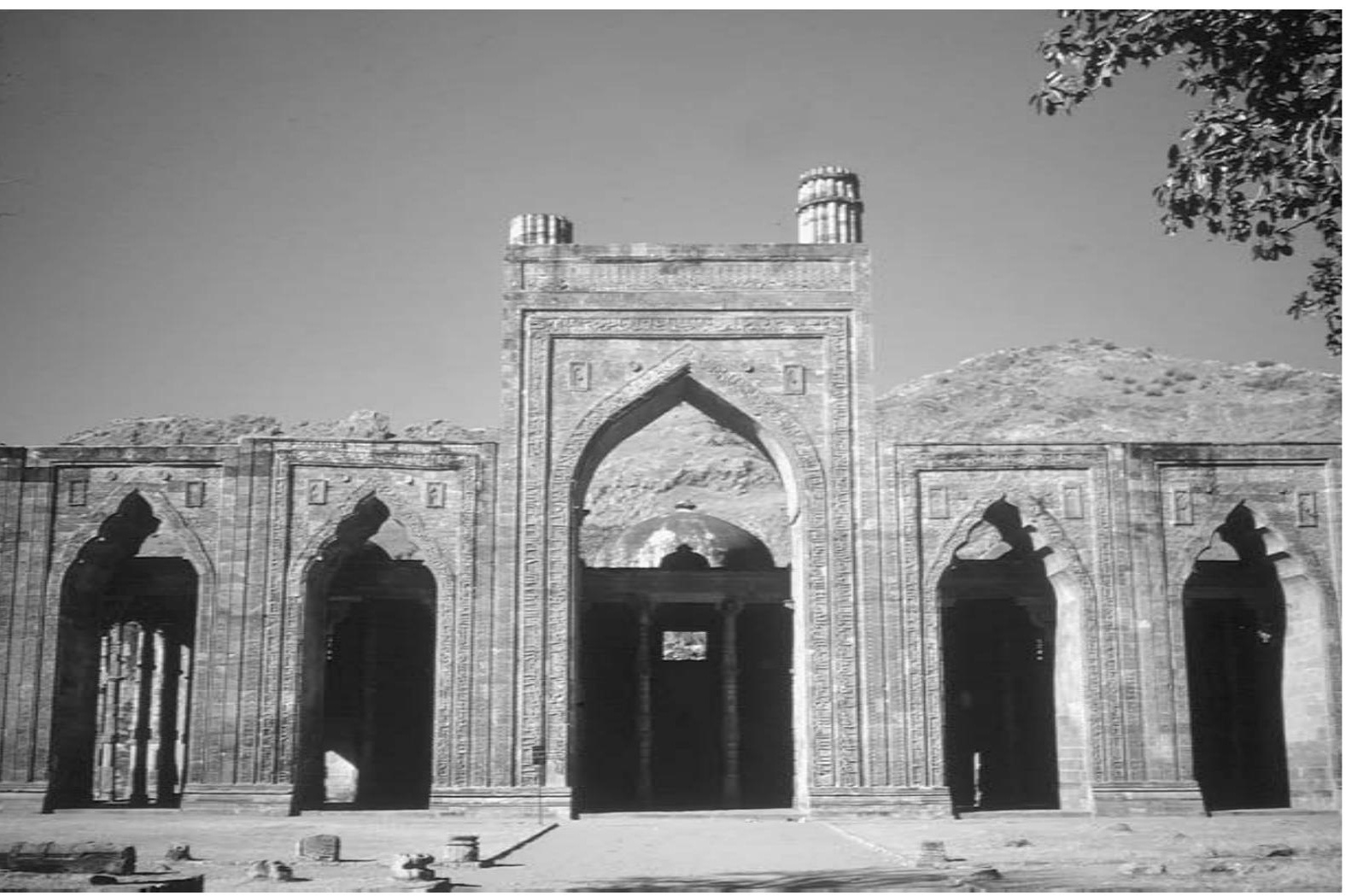

2 Ajmer, Arhā̄ì din kā Jhōmprā mosque, c. 626/1229. (Courtesy George Michell) 


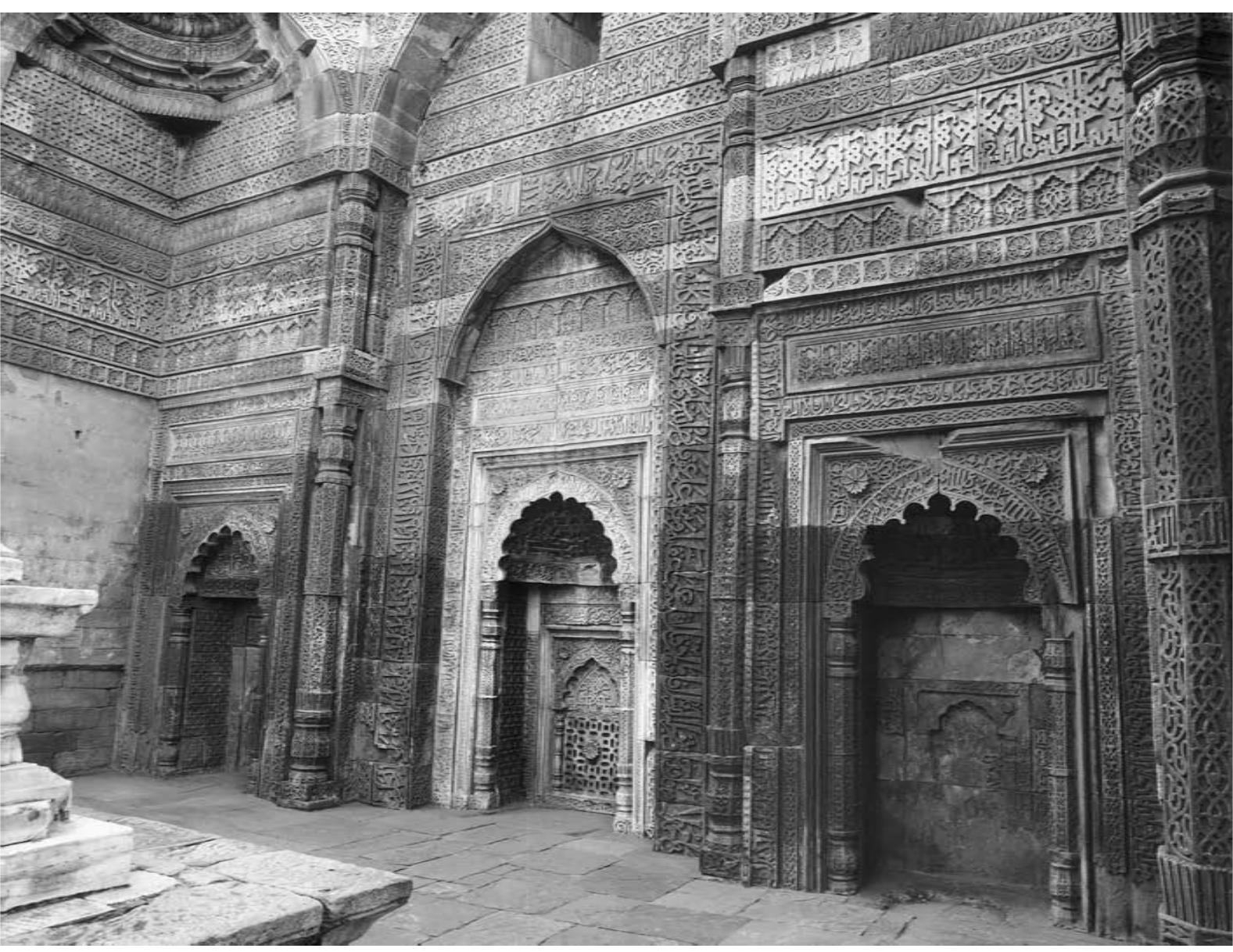

3 Delhi, tomb of Iletmish, c. 632/1235, interior. (Courtesy American Institute of Indian Studies) 


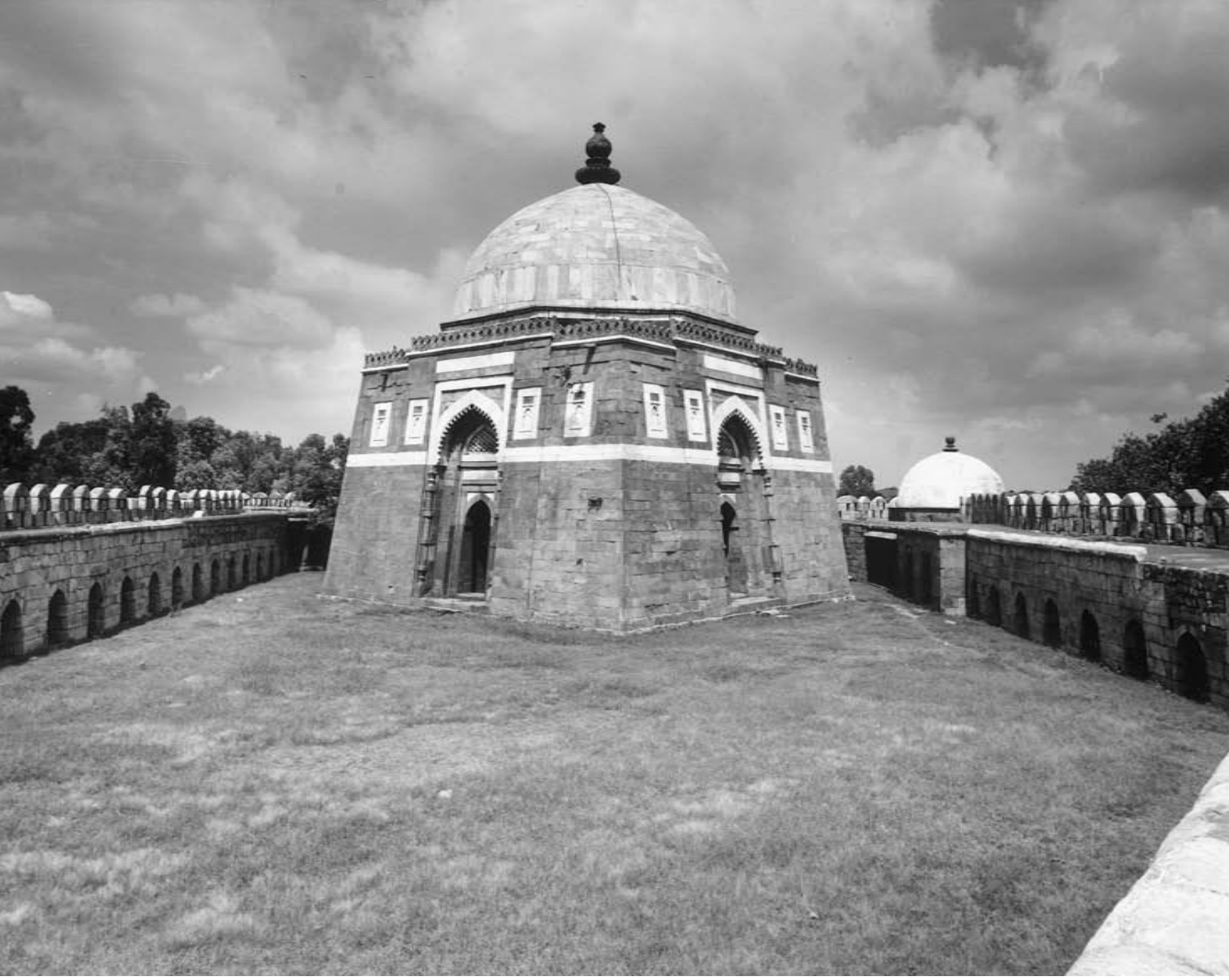

4 Delhi, tomb of Ghiyāth al-Dīn Tughluq, 720-5/1320-5. (Courtesy American Institute of Indian Studies) 


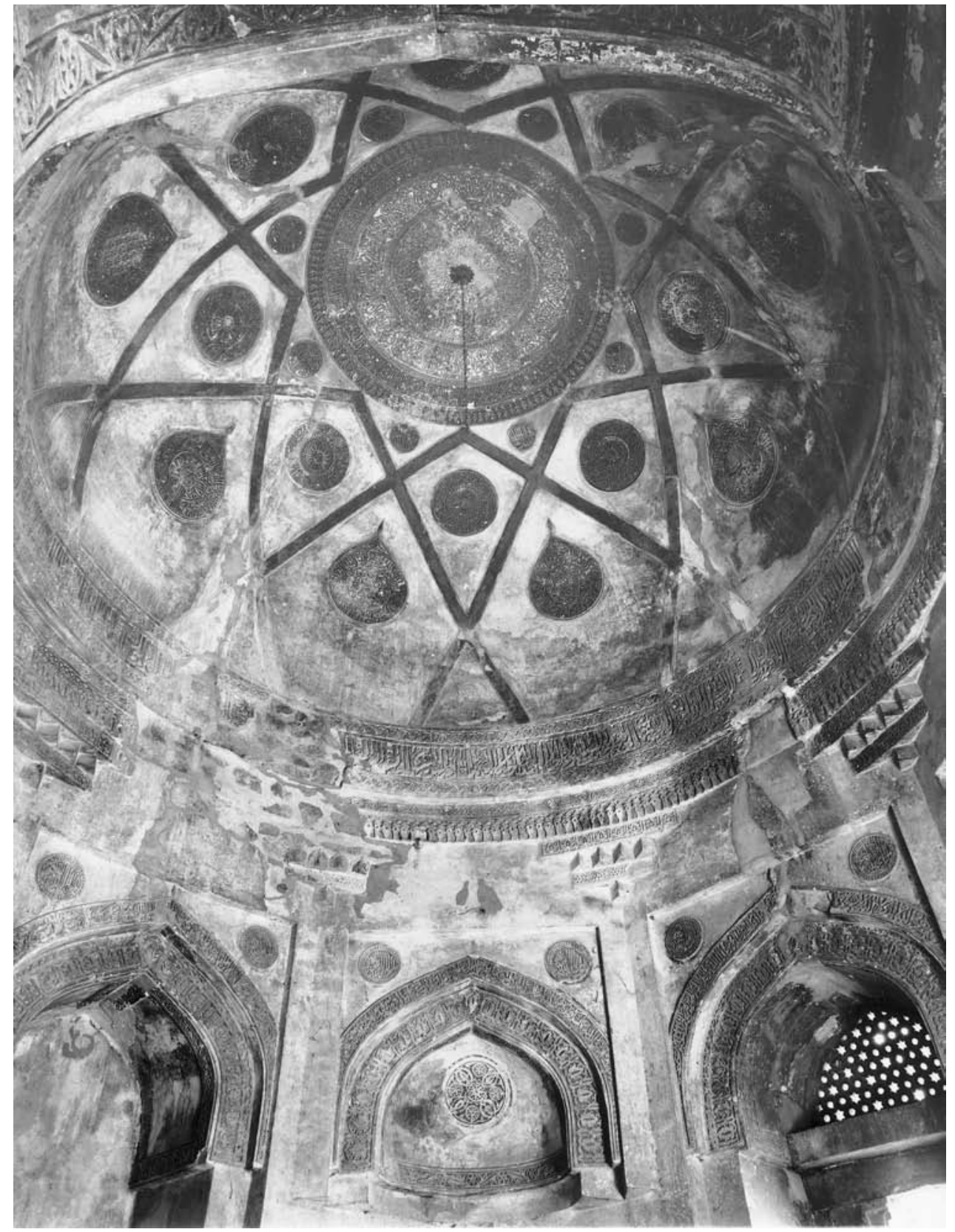

5 Delhi, tomb of Fīrūz Shāh Tughluq, c. 790/1388, dome interior.

(Courtesy American Institute of Indian Studies) 


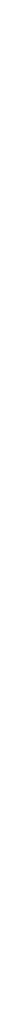

6 Delhi, Fīrūz Shāh Kōtlā, 752-90/1351-88. (Courtesy American Institute of Indian Studies) 


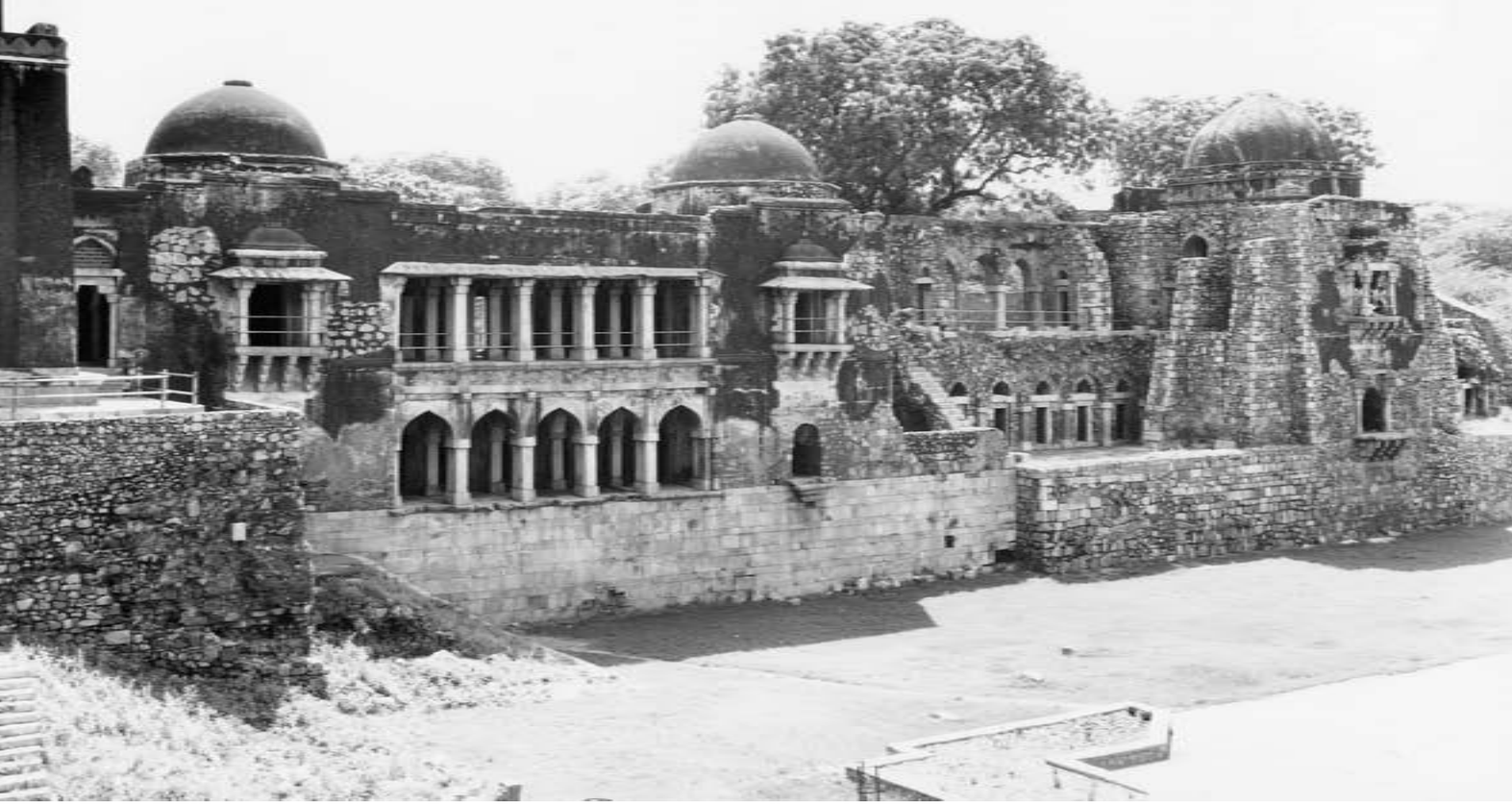

7 Delhi, Ḥauz-i Khāșs, c. 791/1352. (Courtesy American Institute of Indian Studies) 


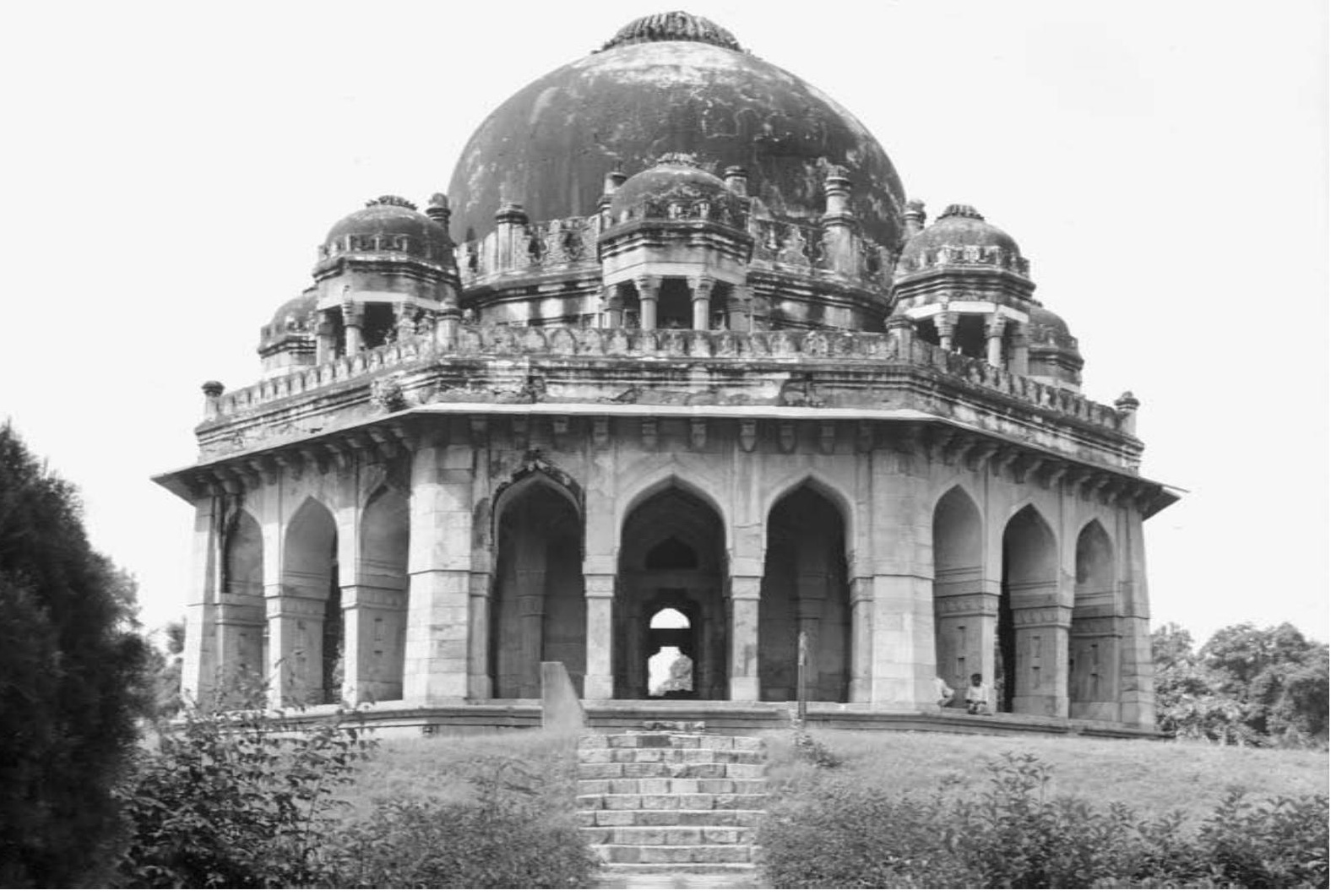

8 Delhi, tomb of Muhammad Shāh Lōdī, c. 848/1444. (Courtesy American Institute of Indian Studies) 


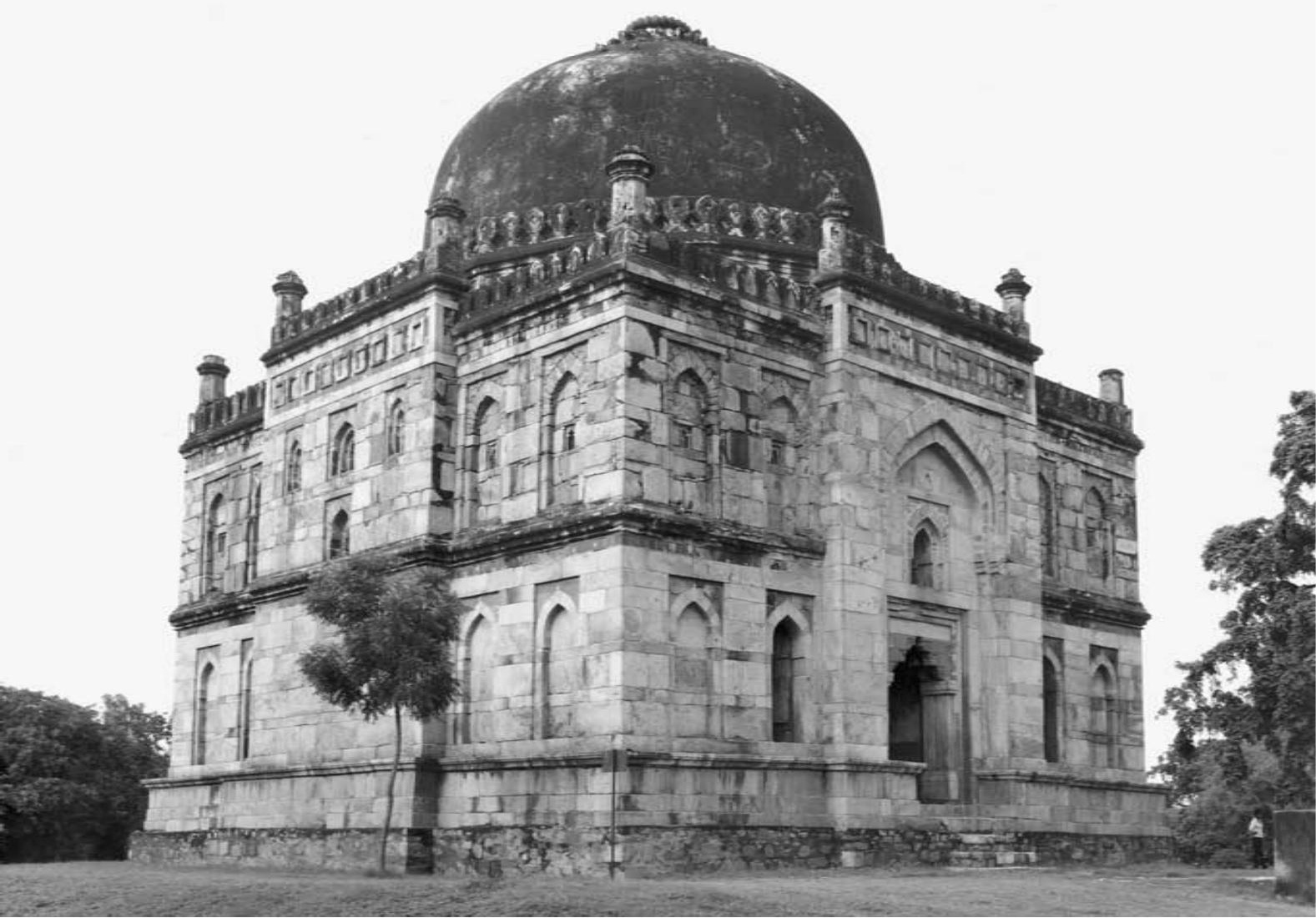

9 Delhi, Shīsh Gunbad, 894-923/1489-1517. (Courtesy American Institute of Indian Studies) 


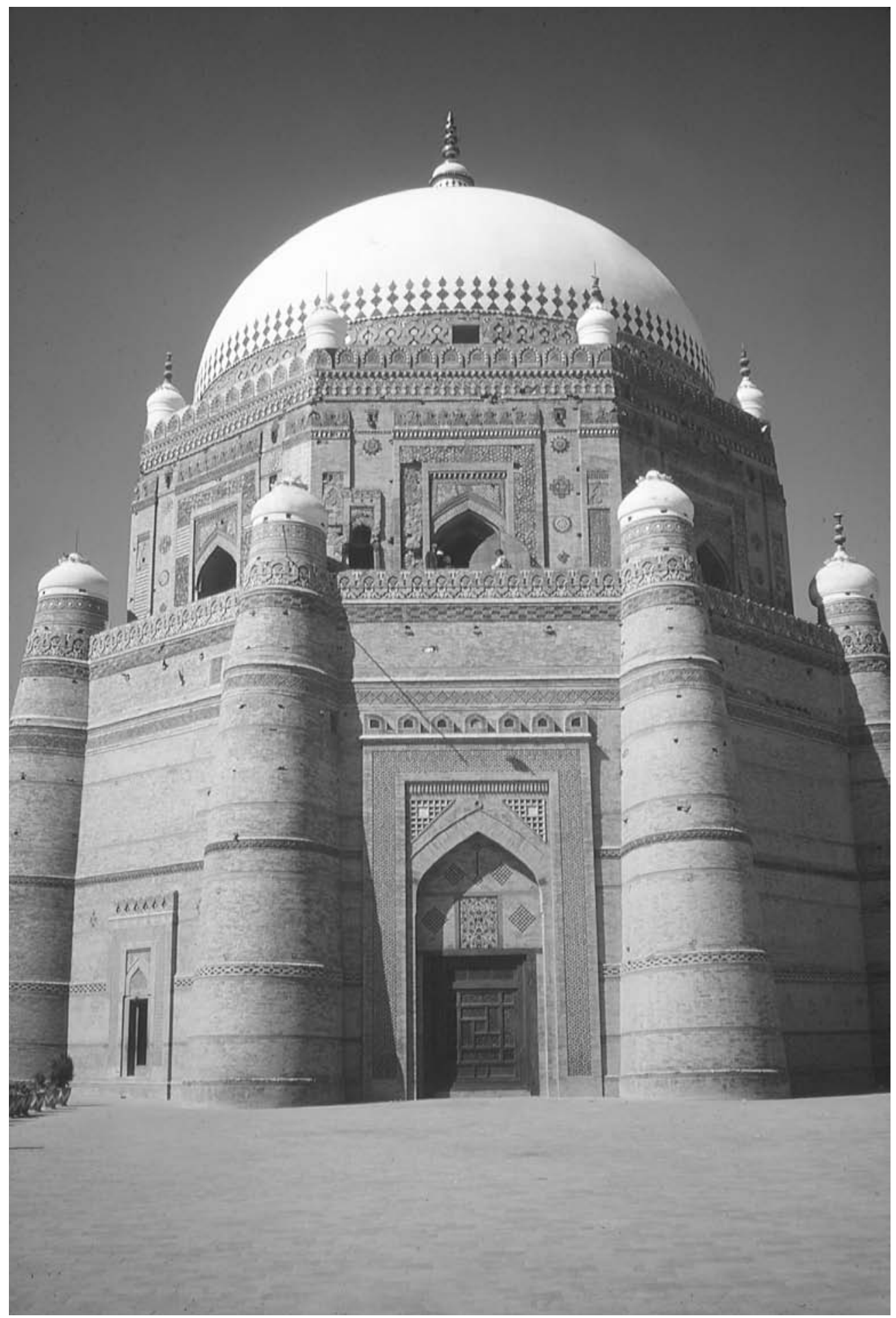

10 Multan, tomb of Rukn-i 'Ālam, mid $14^{\text {th }}$ century. (Courtesy George Michell) 


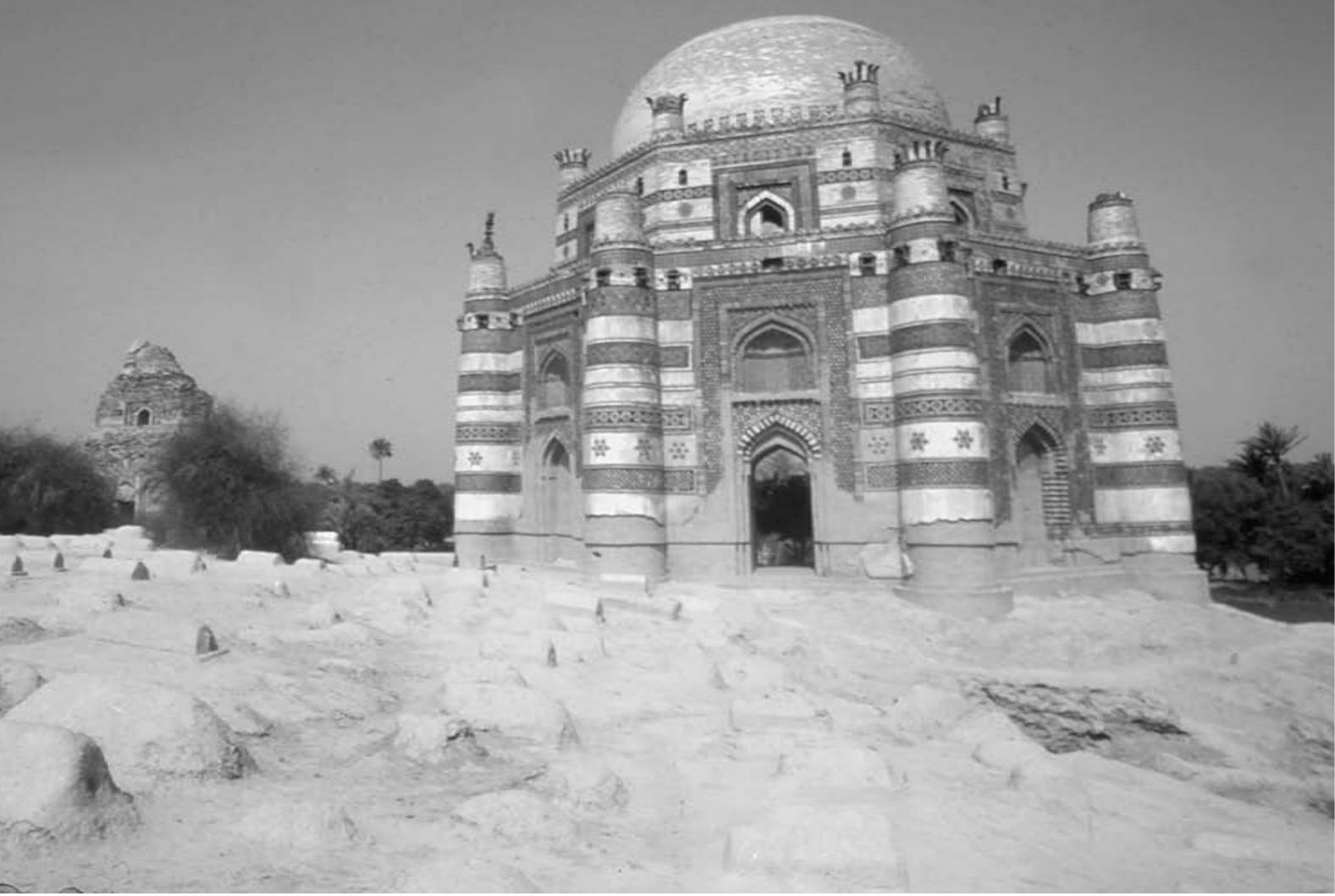

11 Ucch, tomb of Bībī Jiwindi, 900/1493. (Courtesy Tanvir Hasan) 


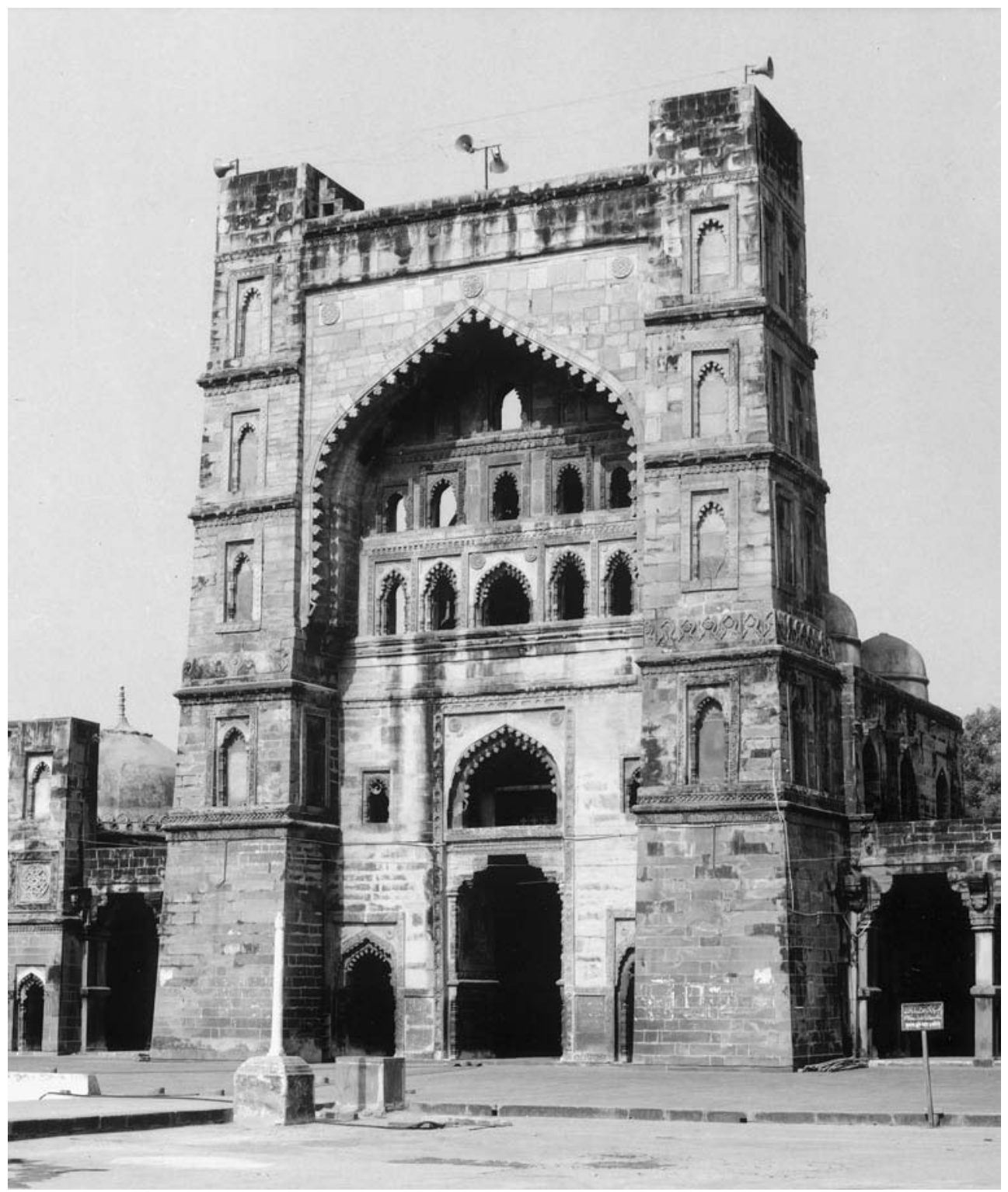

12 Jaunpur, Atalā mosque, 810/1408. (Courtesy American Institute of Indian Studies) 


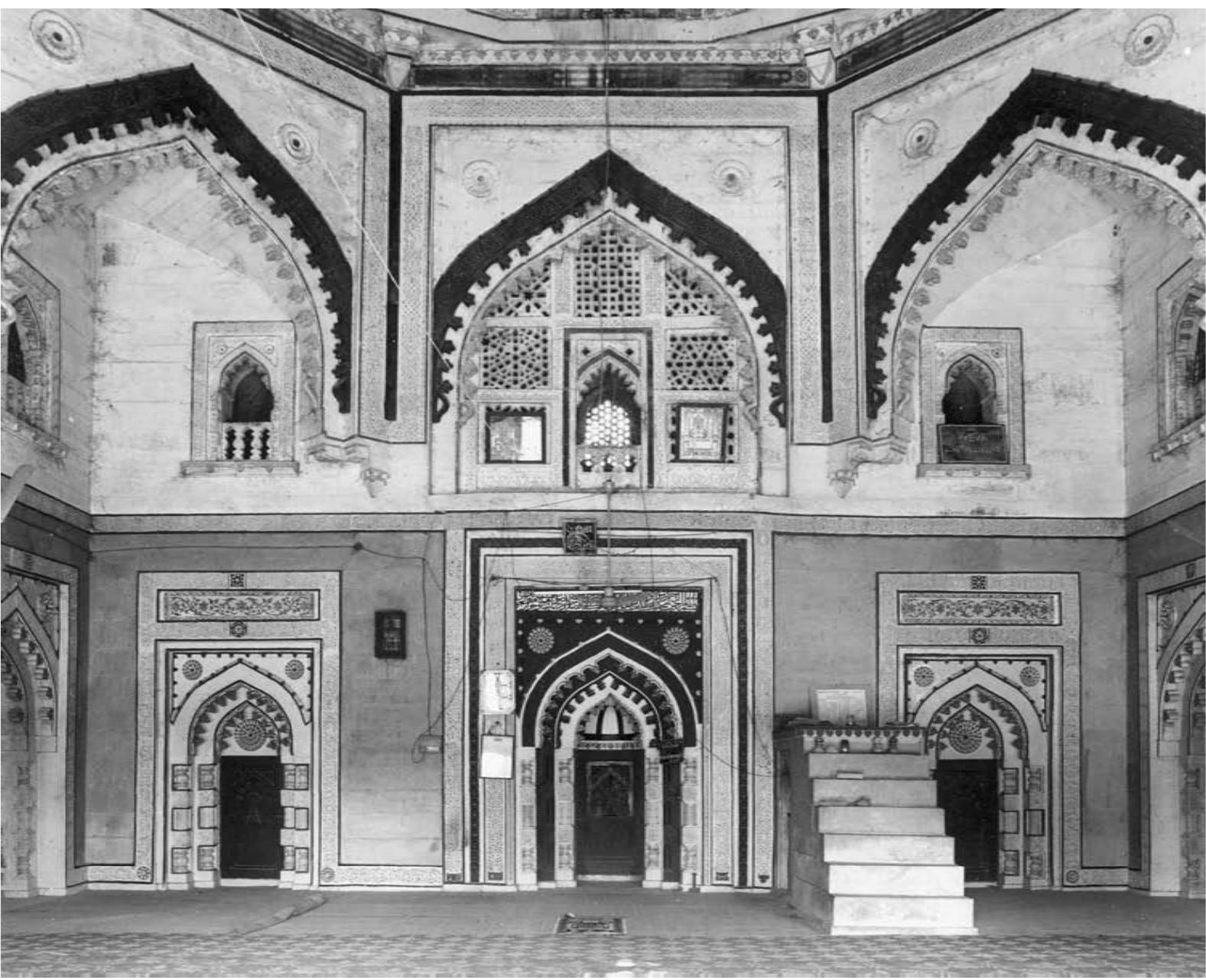

13 Jaunpur, Jāmi' Masjid, 842/1438, interior. (Courtesy American Institute of Indian Studies) 


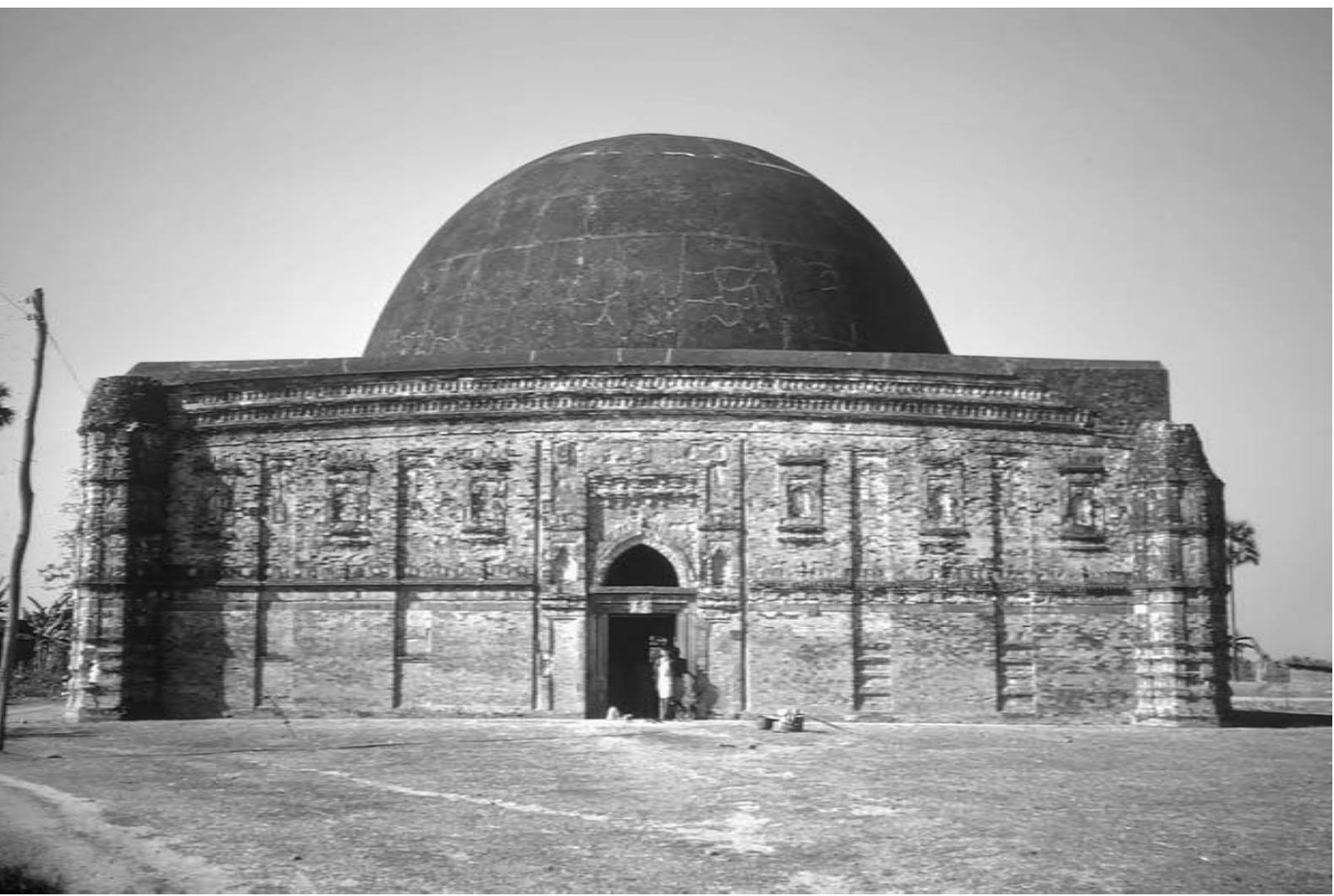

14 Pandua, Ēklākhī tomb, early $15^{\text {th }}$ century. (Courtesy George Michell) 


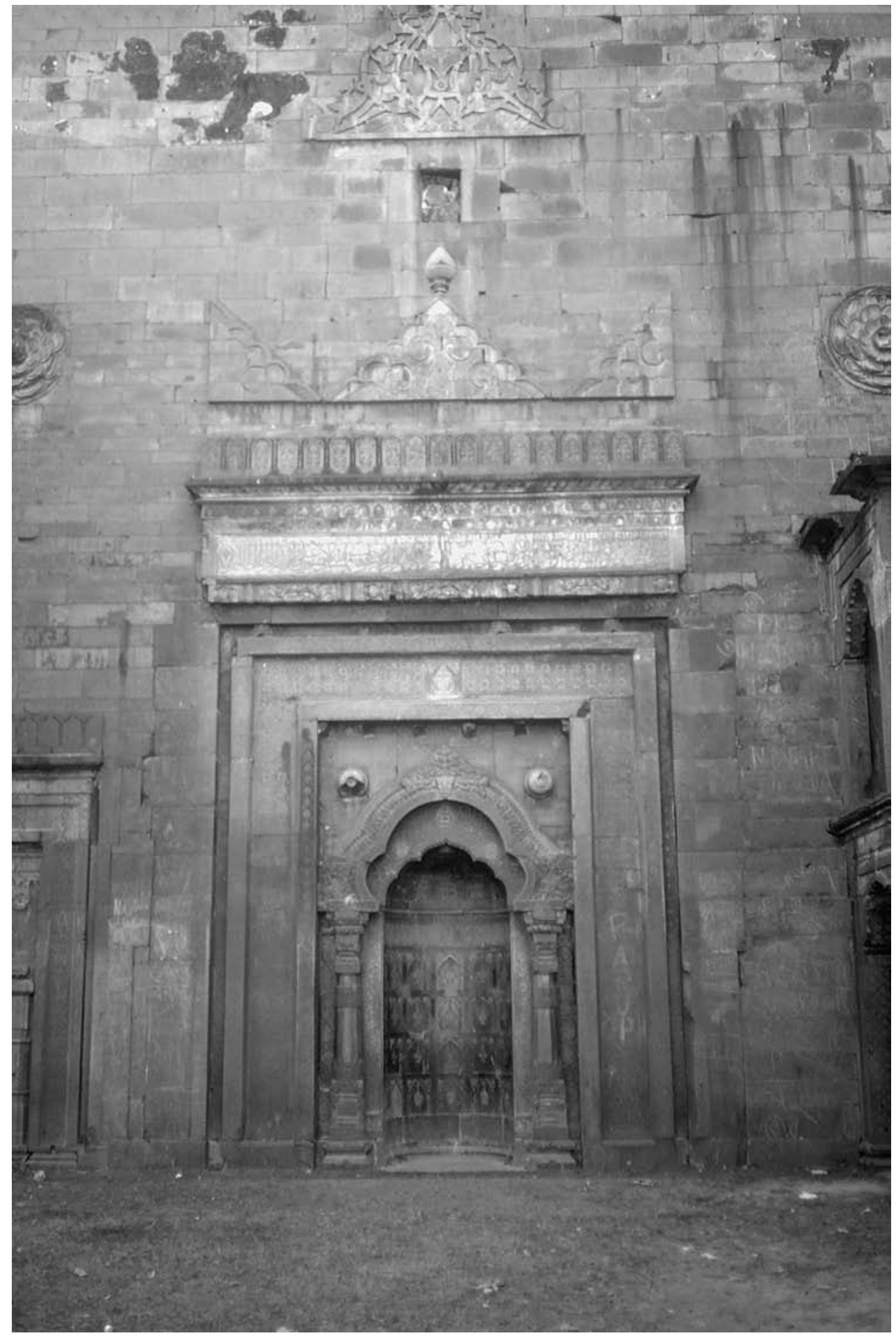

15 Hazrat Pandua, Ādīna Masjid, 776/1374-5, mihrāab. (Courtesy George Michell) 


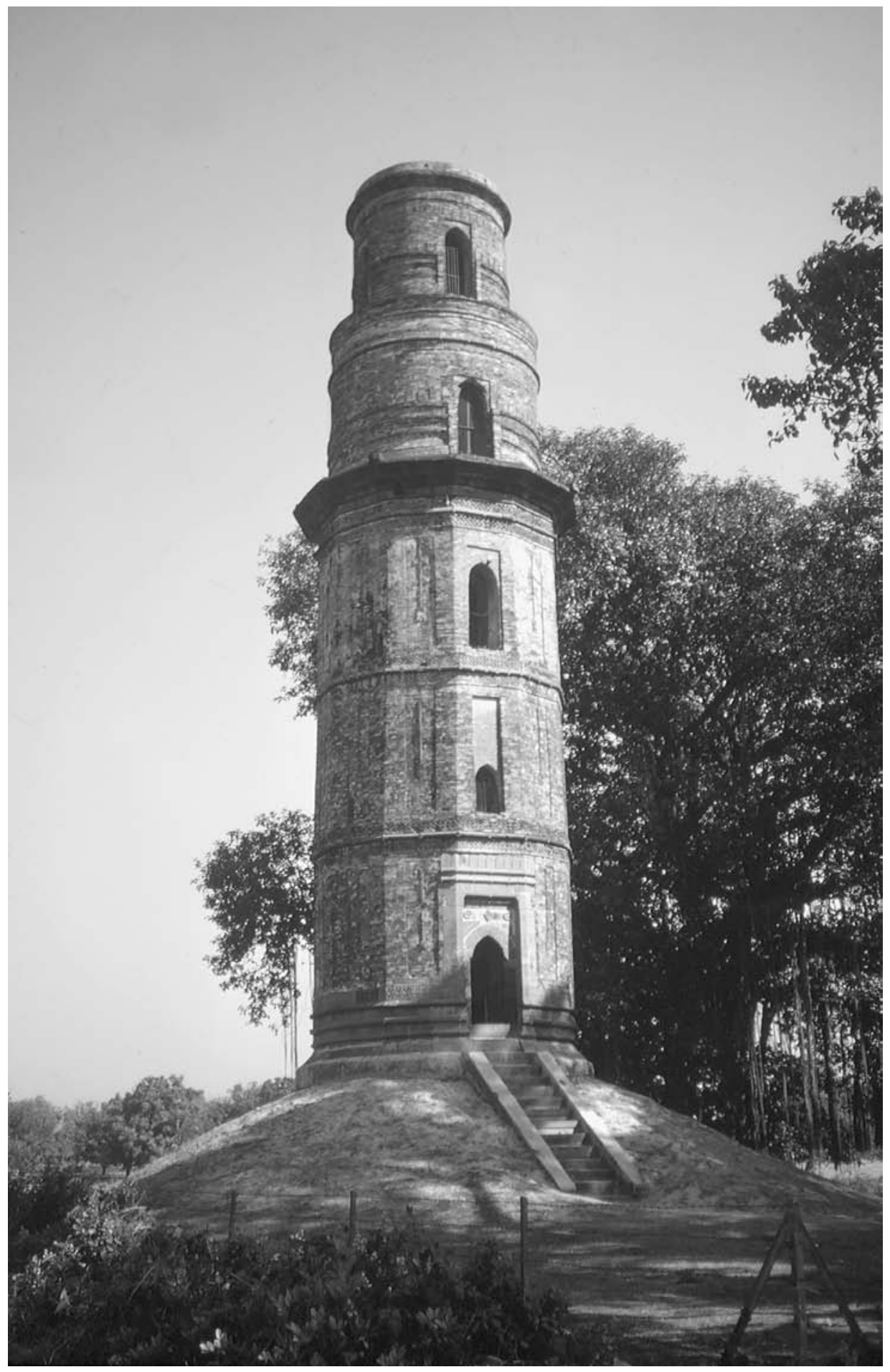

16 Gaur, Fīrūz Mīnār, c. 895/1490. (Courtesy George Michell) 


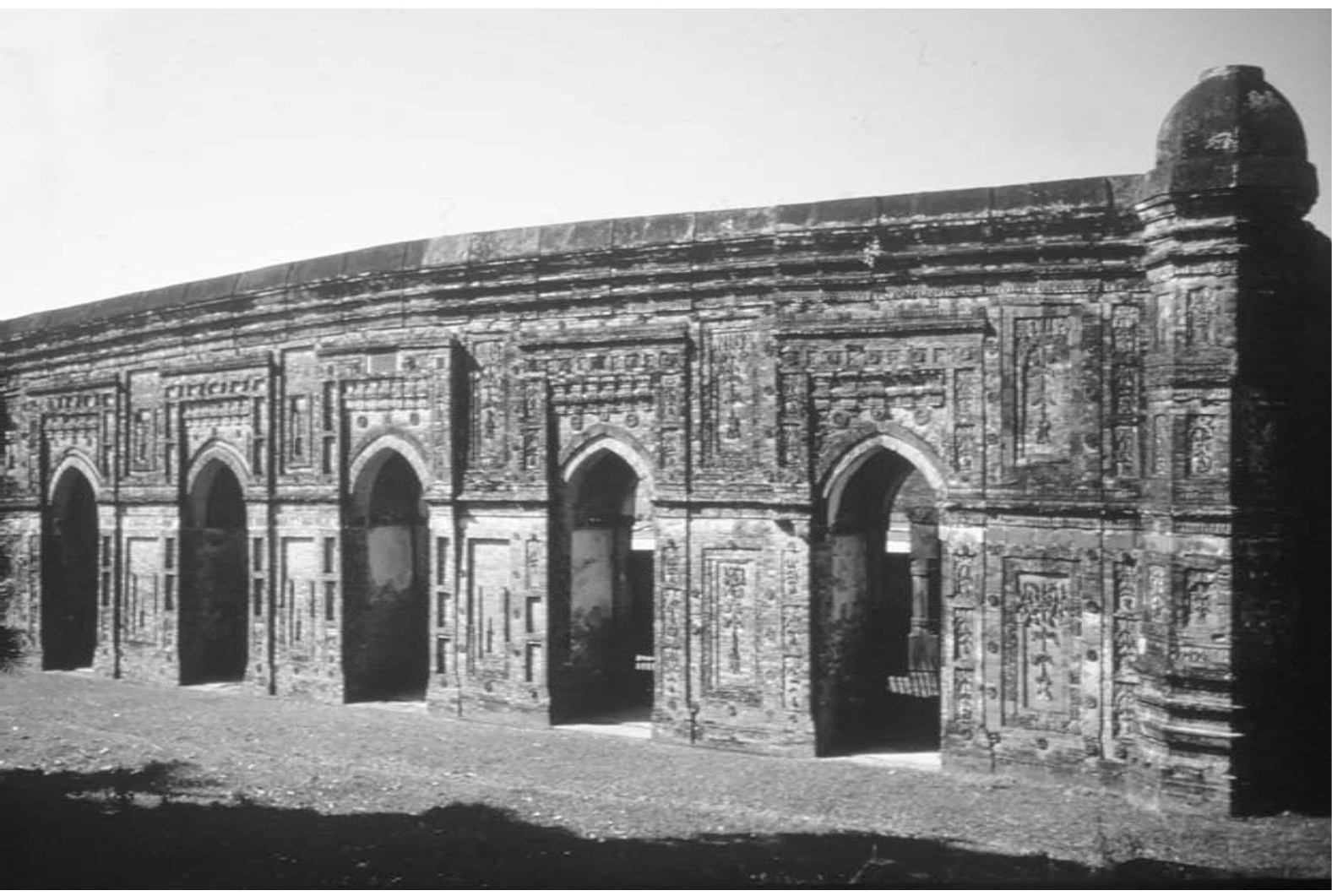

17 Bagha, Jāmi` Masjid, 930/1523. (Courtesy Estate of David McCutchion) 


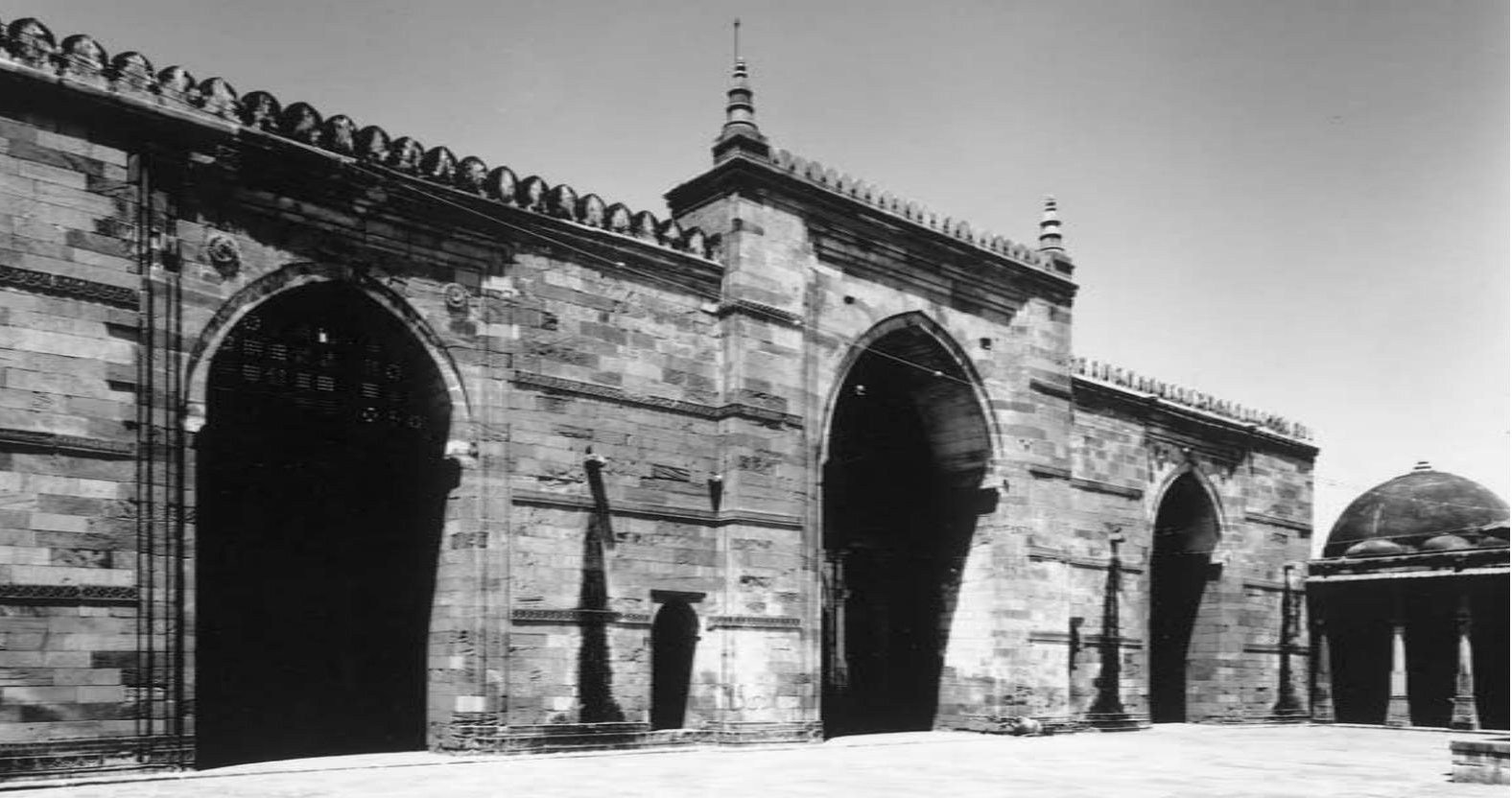

18 Cambay, Jāmi` Masjid, 725/1325. (Courtesy American Institute of Indian Studies) 


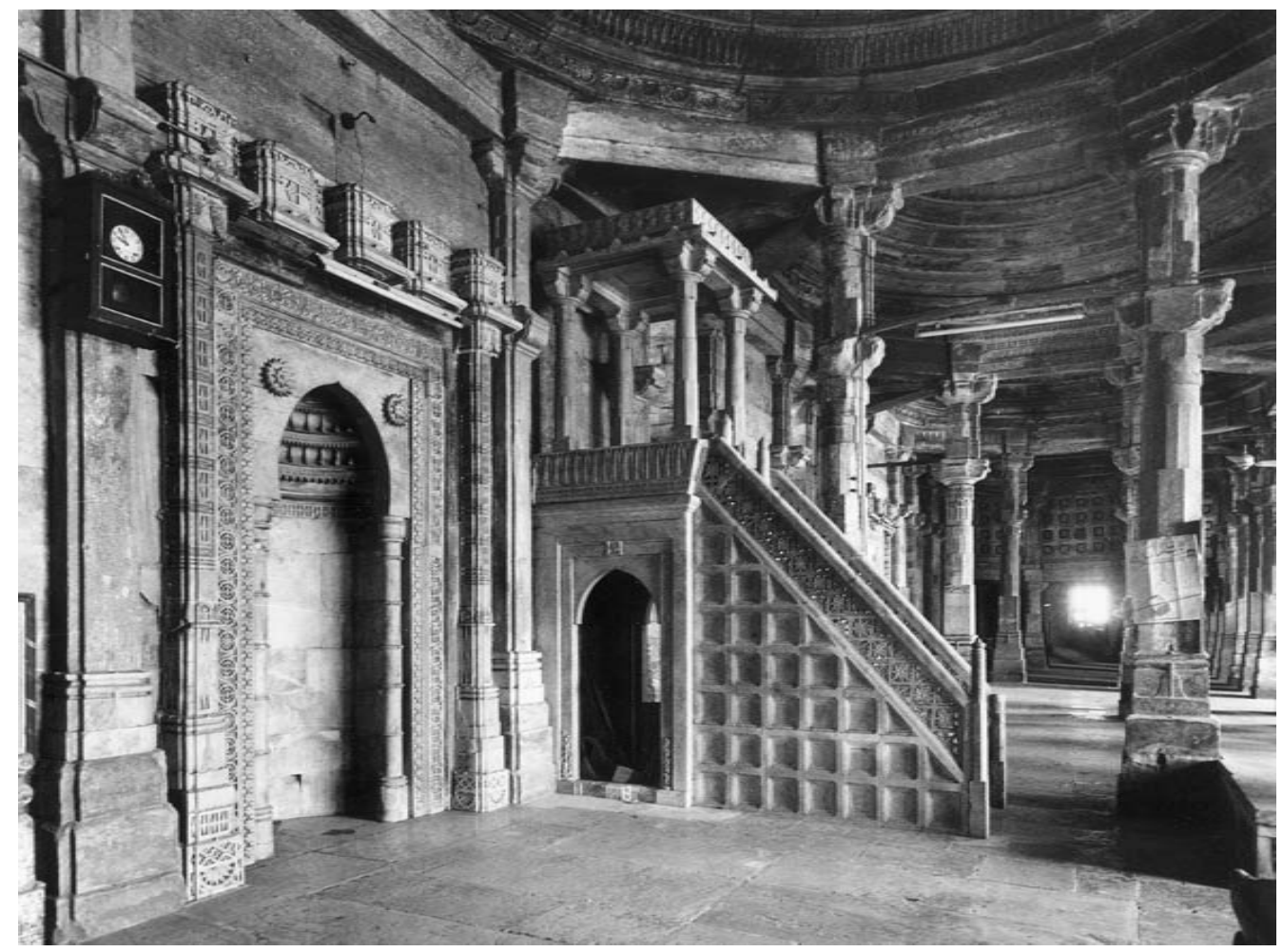

19 Cambay, Jāmi 'Masjid, interior. (Courtesy American Institute of Indian Studies) 


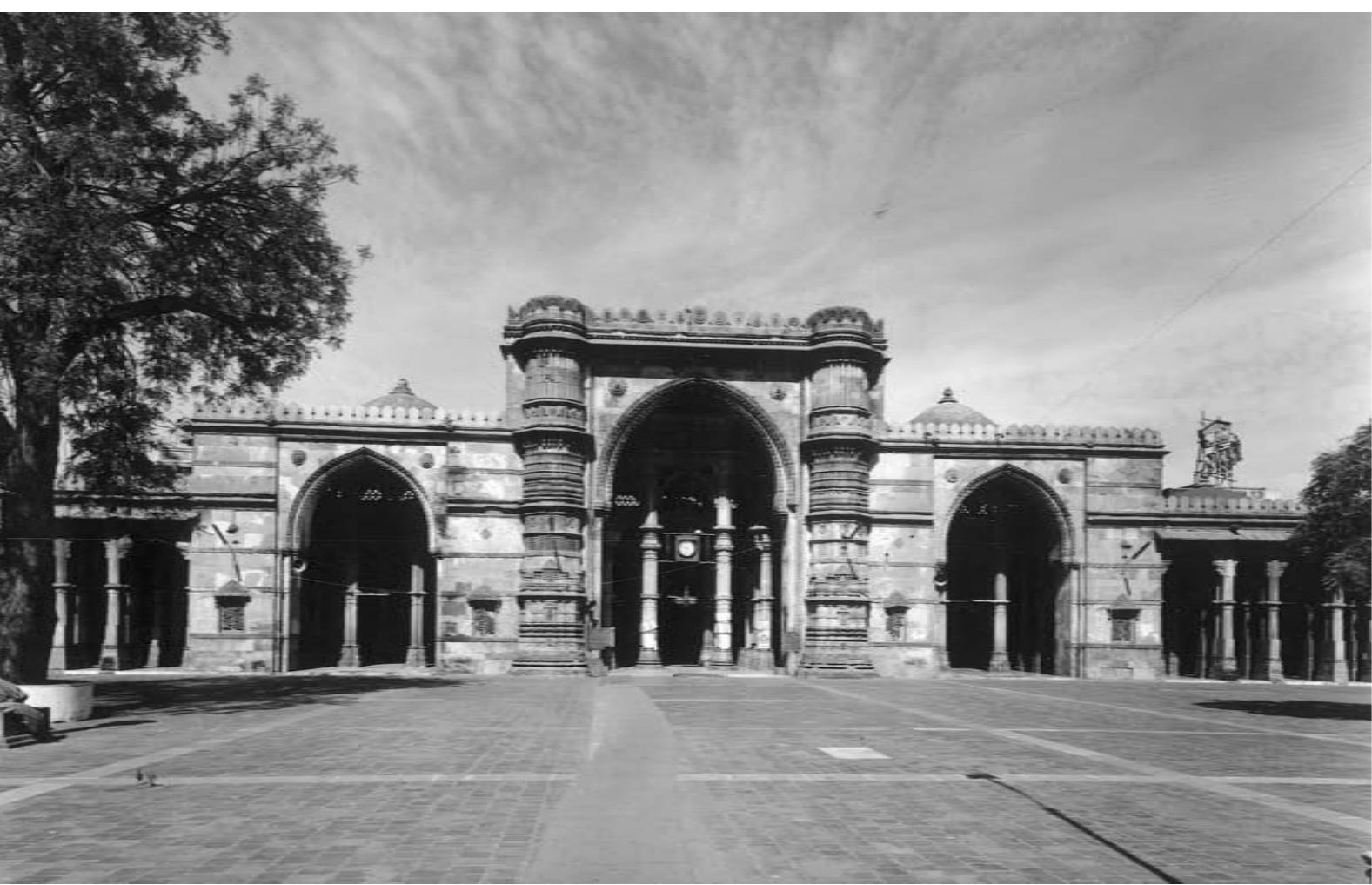

20 Ahmadabad, Jāmi` Masjid, 827/1424. (Courtesy American Institute of Indian Studies) 


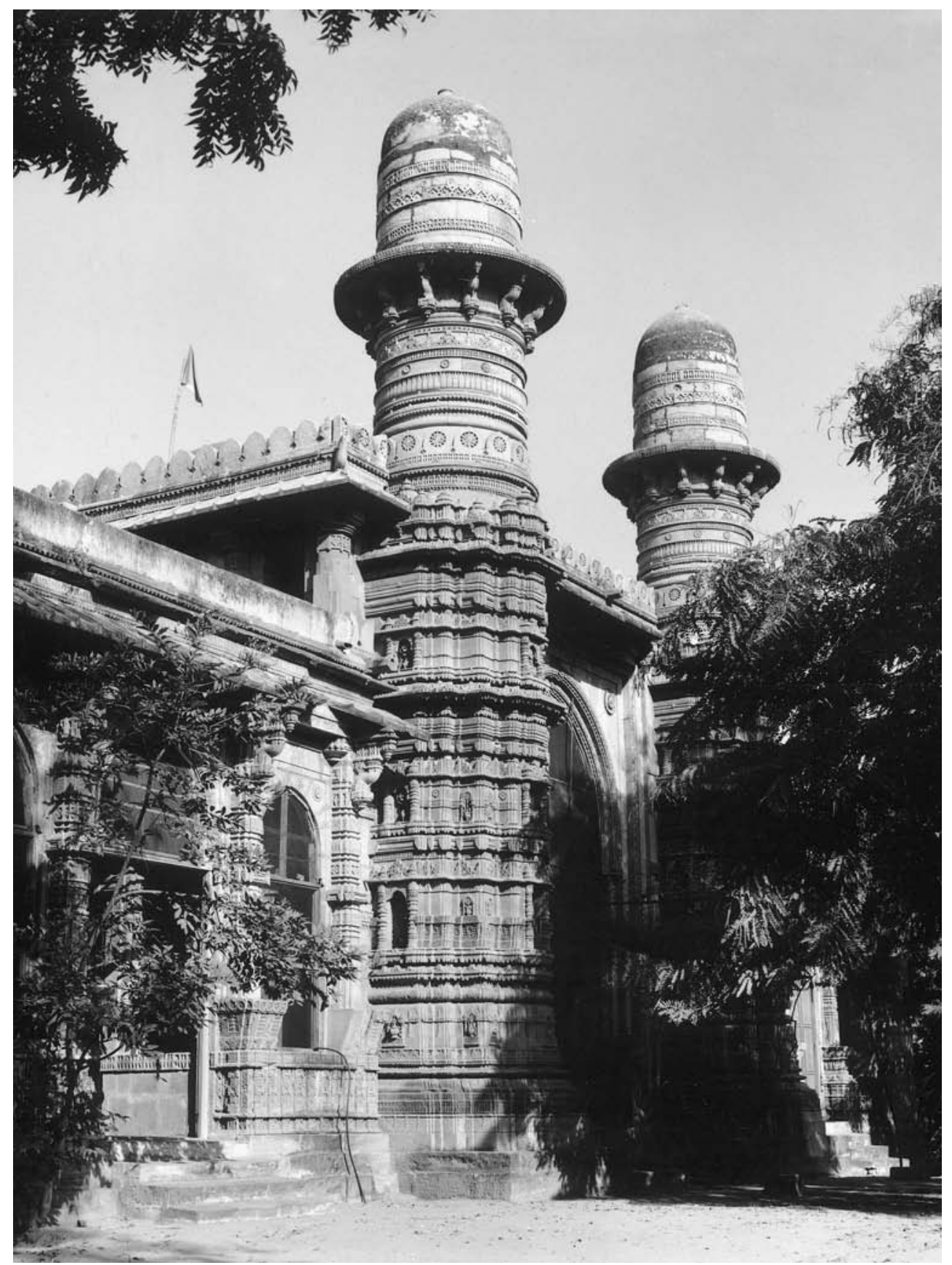

21 Ahmadabad, mosque of Miyān Khān Chishtī, c. 869/1465.

(Courtesy American Institute of Indian Studies) 


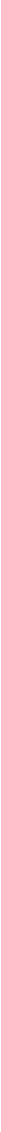

22 Ahmadabad, tomb of Az'am-Mu'azzam, late $15^{\text {th }}$ century. (Courtesy American Institute of Indian Studies) 




24 Ahmadabad, Bābā Lului's mosque, first quarter of the $16^{\text {th }}$ century, façade detail. (Courtesy American Institute of Indian Studies) 


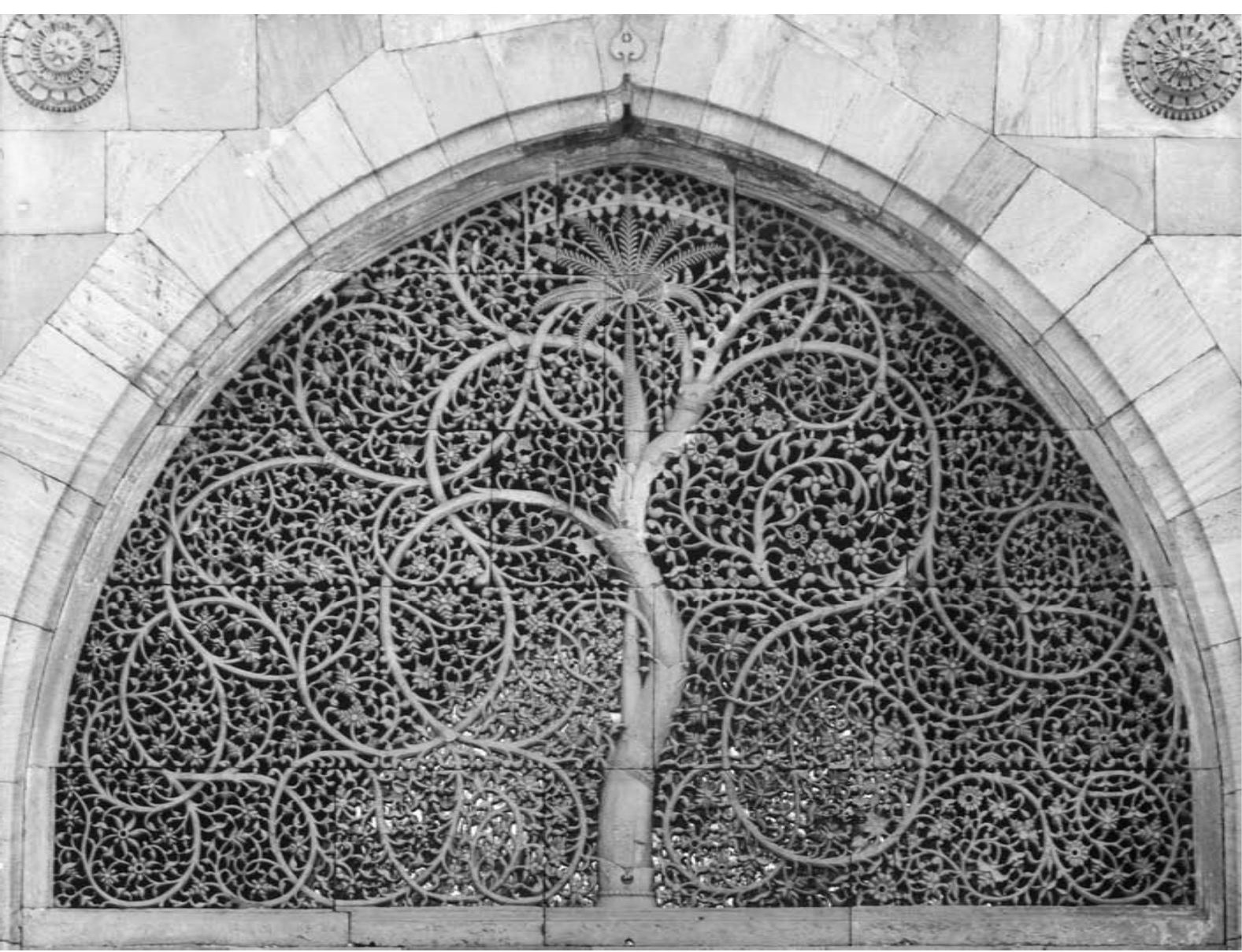

25 Ahmadabad, mosque of Sidī Sa î̀, 980/1572,jālì. (Courtesy American Institute of Indian Studies) 


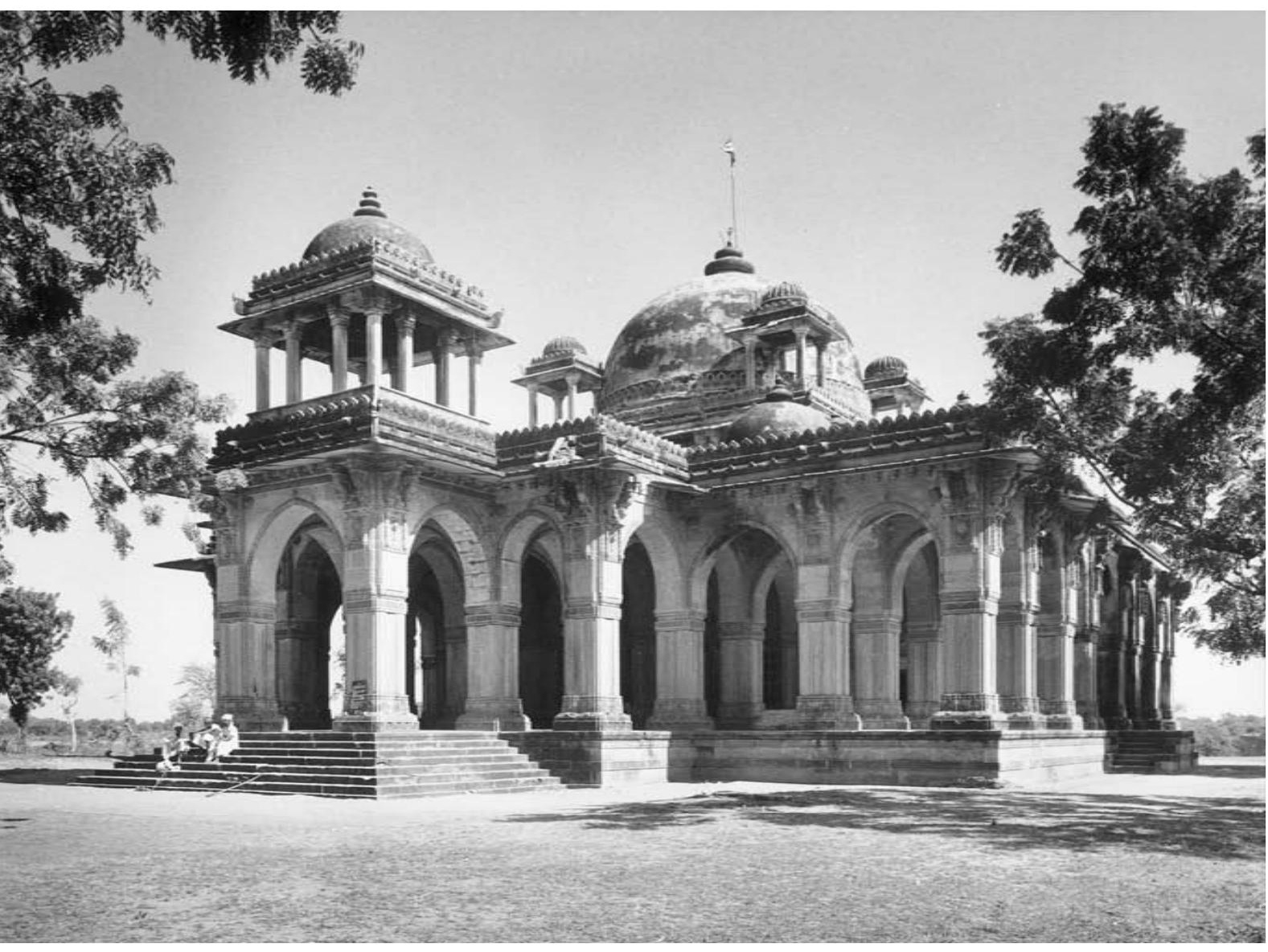

26 Mahmudabad, tomb of Sayyid Mubārak Bukhāri, after 966/1588. (Courtesy American Institute of Indian Studies) 


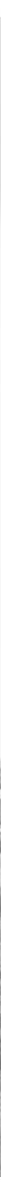

27 Gwalior, tomb of Muhammad Ghaus, after 969/1562. (Courtesy American Institute of Indian Studies) 


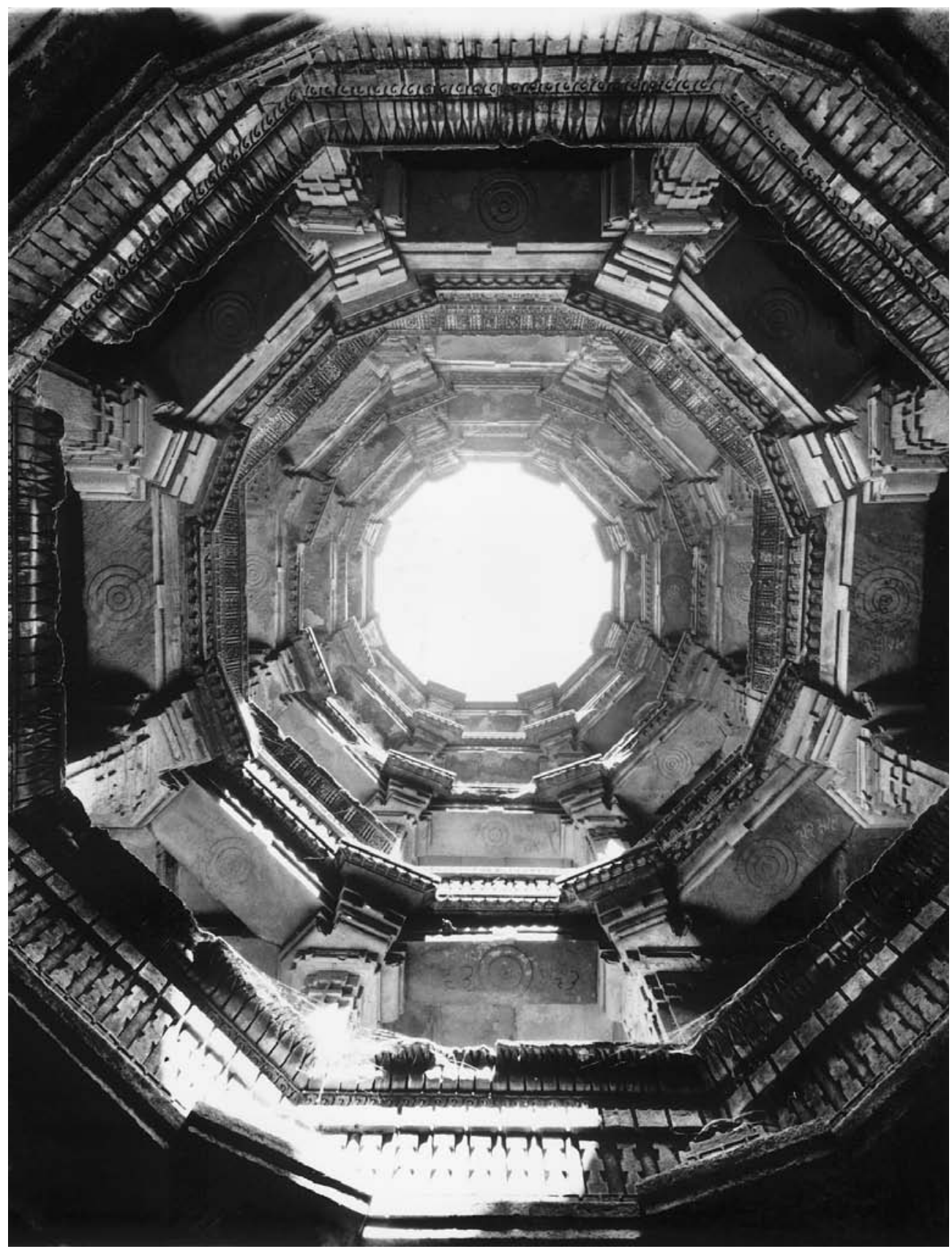

28 Ahmadabad, Bāī Ḥarīr's vā̄v, 906/1500. (Courtesy American Institute of Indian Studies) 


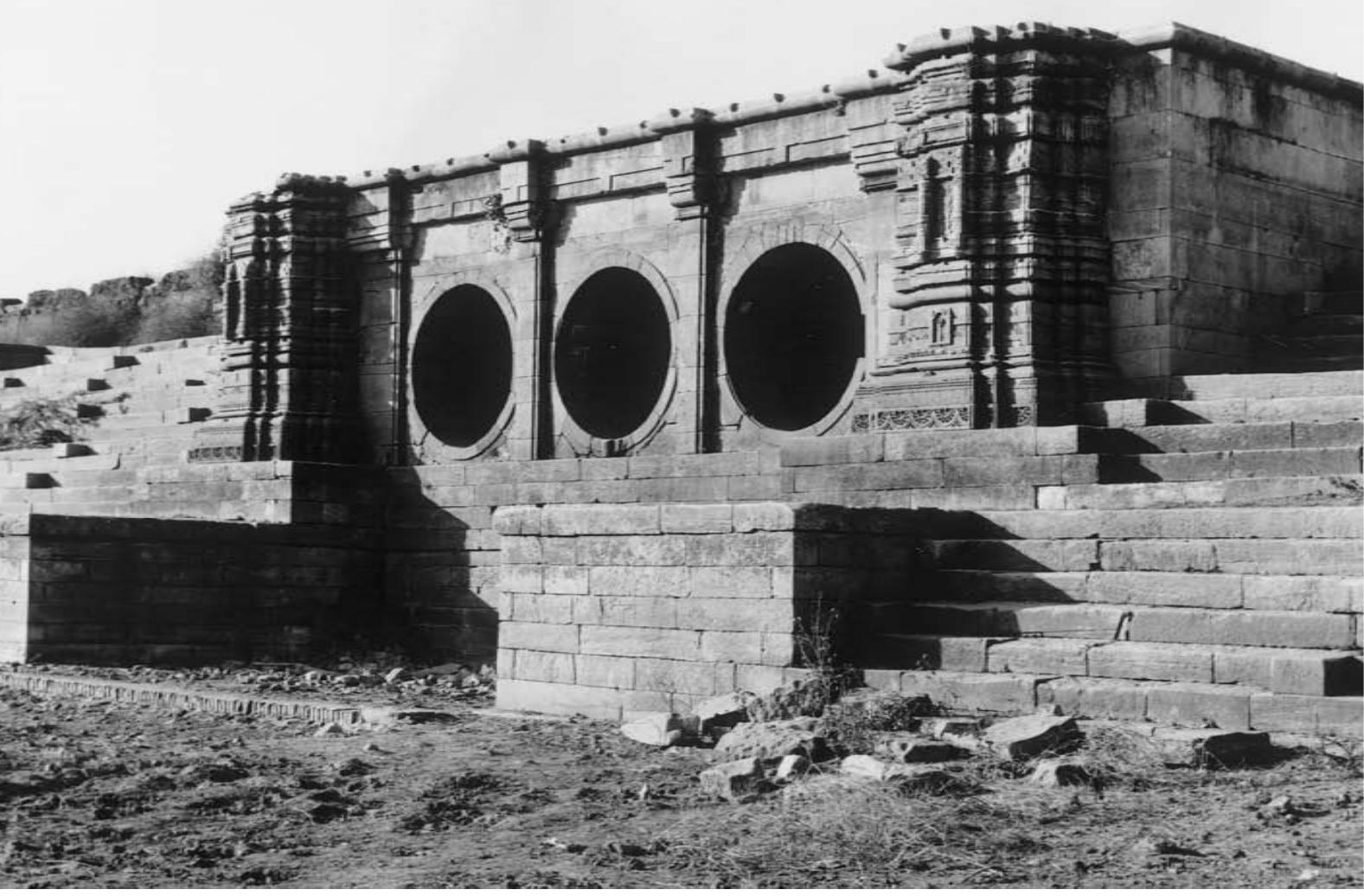

29 Sarkhej, water sluice, early $16^{\text {th }}$ century. (Courtesy American Institute of Indian Studies) 


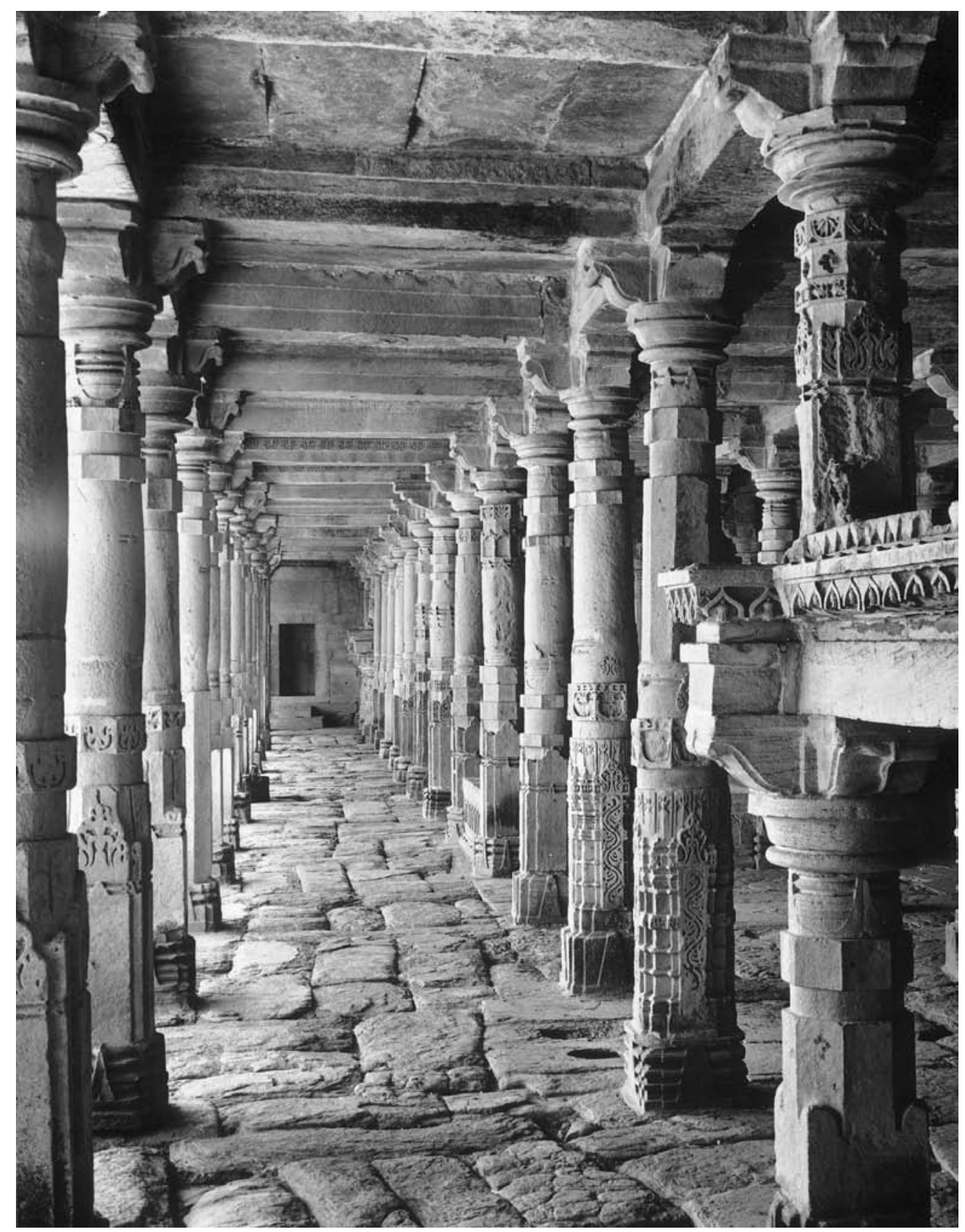

30 Dhar, Lāt Masjid, interior, 807/1405. (Courtesy American Institute of Indian Studies) 


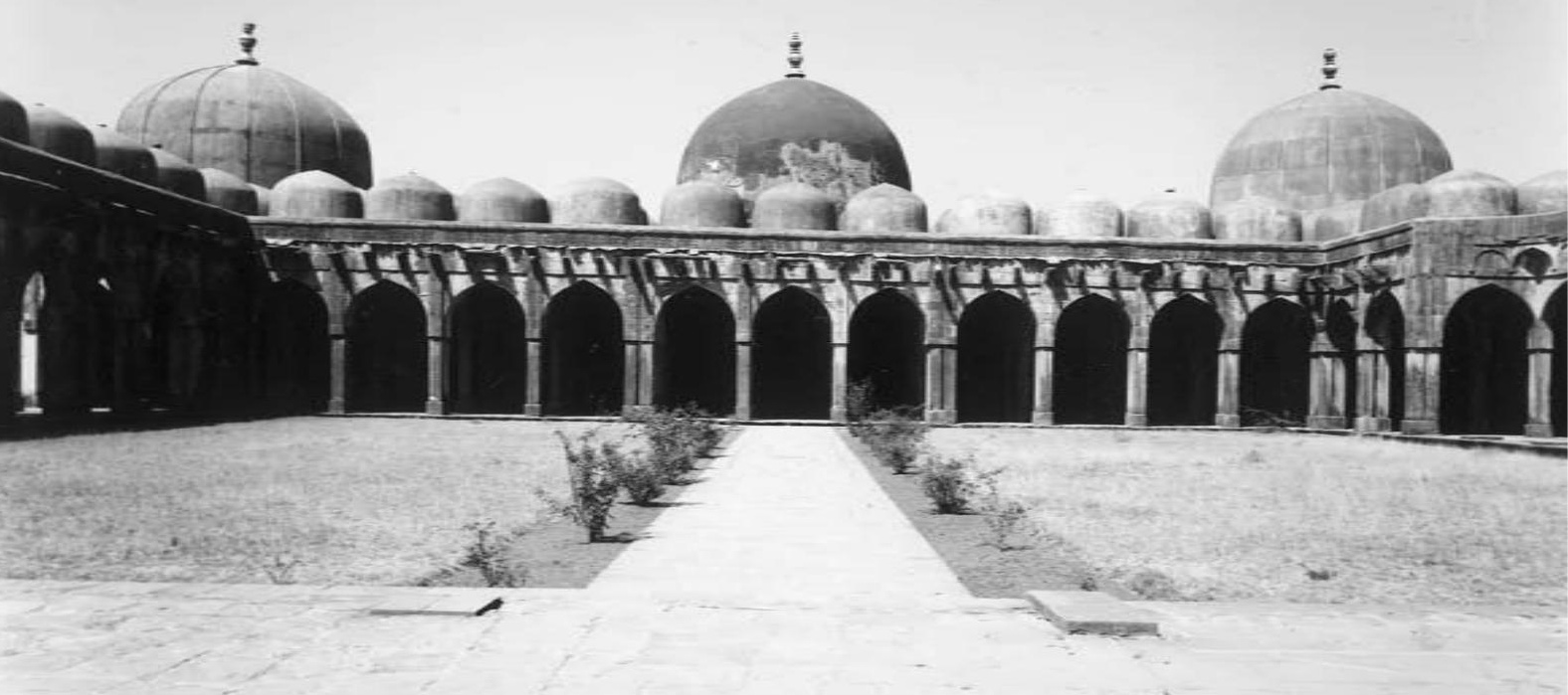

31 Mandu, Jāmi` Masjid, 858/1454. (Courtesy American Institute of Indian Studies) 


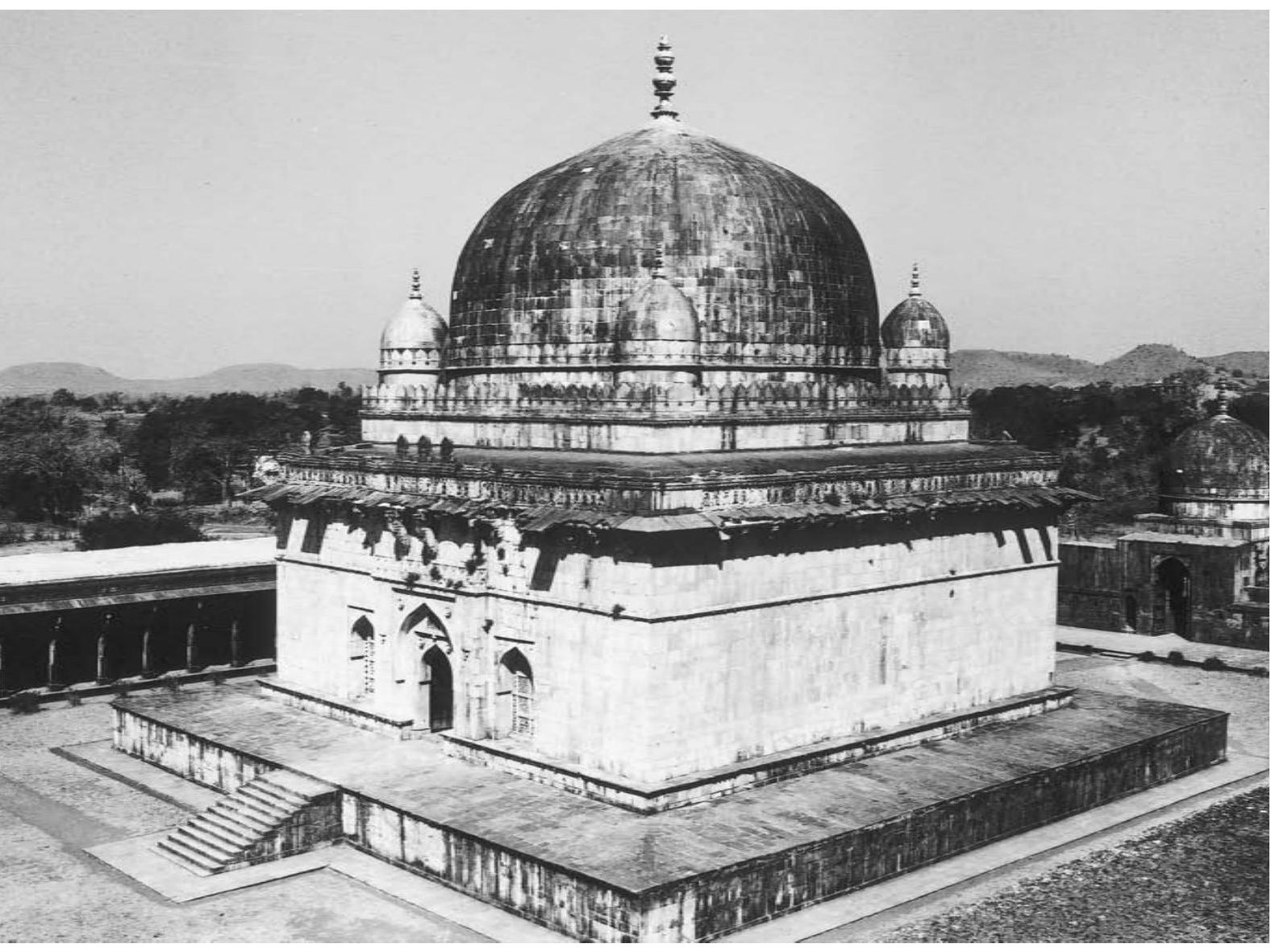

32 Mandu, tomb of Hūshang Shāh, c. 842/1439. (Courtesy Klaus Rötzer) 


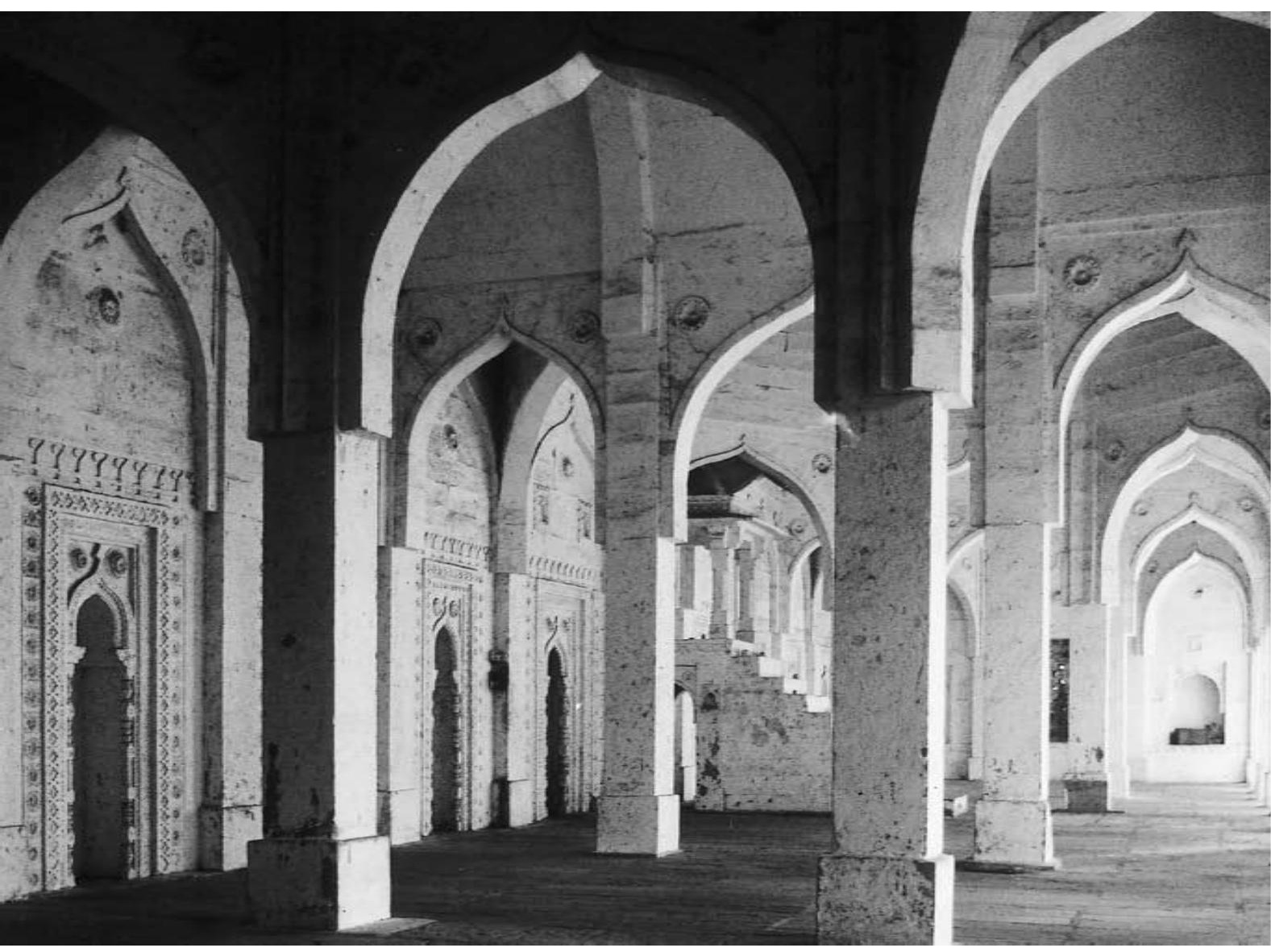

33 Chanderi, Jāmi ${ }^{\top}$ Masjid, mid $15^{\text {th }}$ century, interior. (Courtesy Klaus Rötzer) 


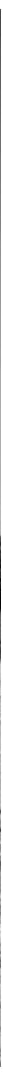

34 Thalner, tombs of Mīrān Mubārak Khān and others, $15^{\text {th }}$ century (Courtesy John Henry Rice) 


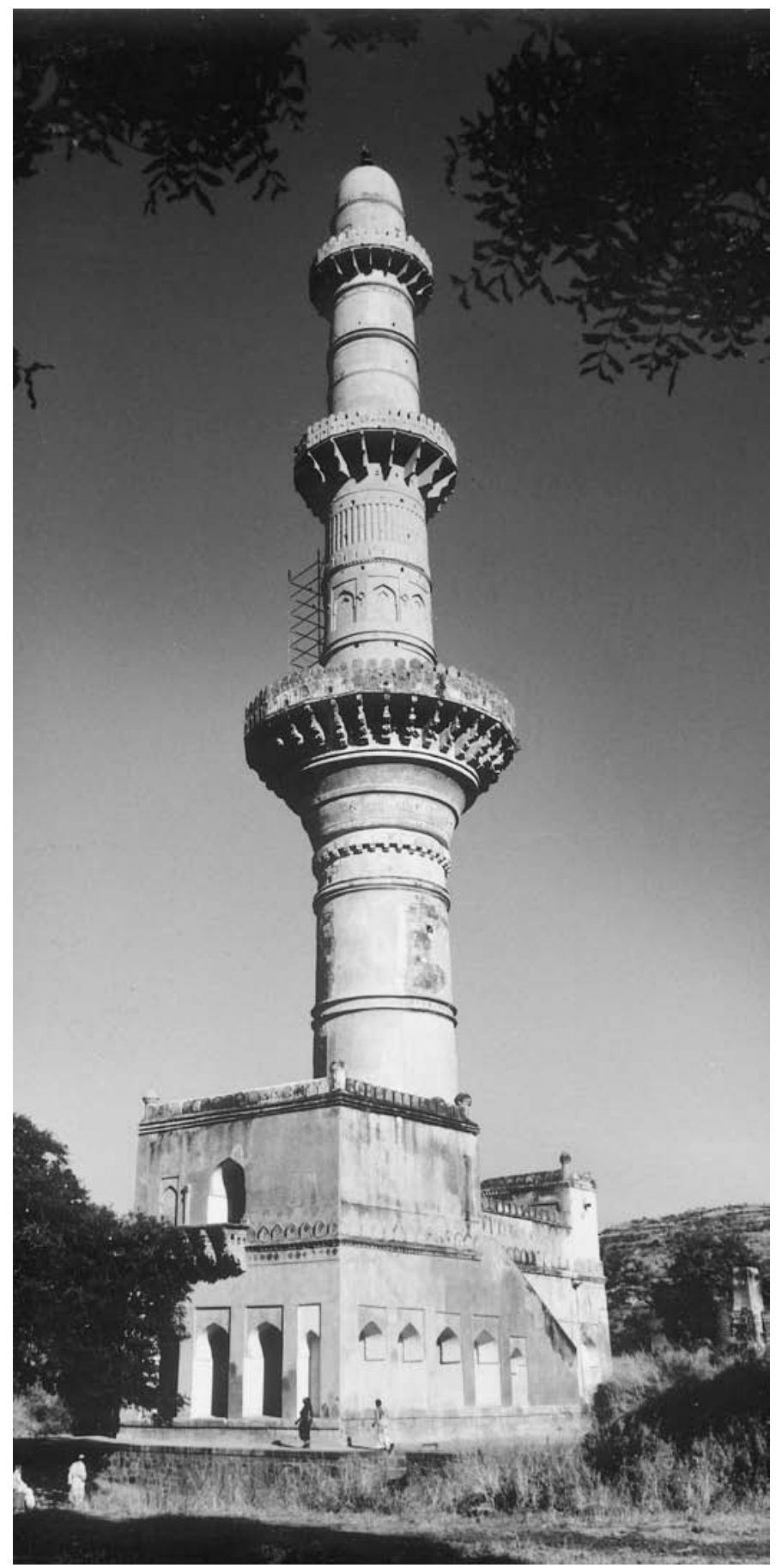

35 Daulatabad, Chānd Mīnār, c. 849/1445. (Courtesy American Institute of Indian Studies) 




36 Gulbarga, Jāmi` Masjid, 769/1367 (?), interior. (Courtesy John Gollings) 


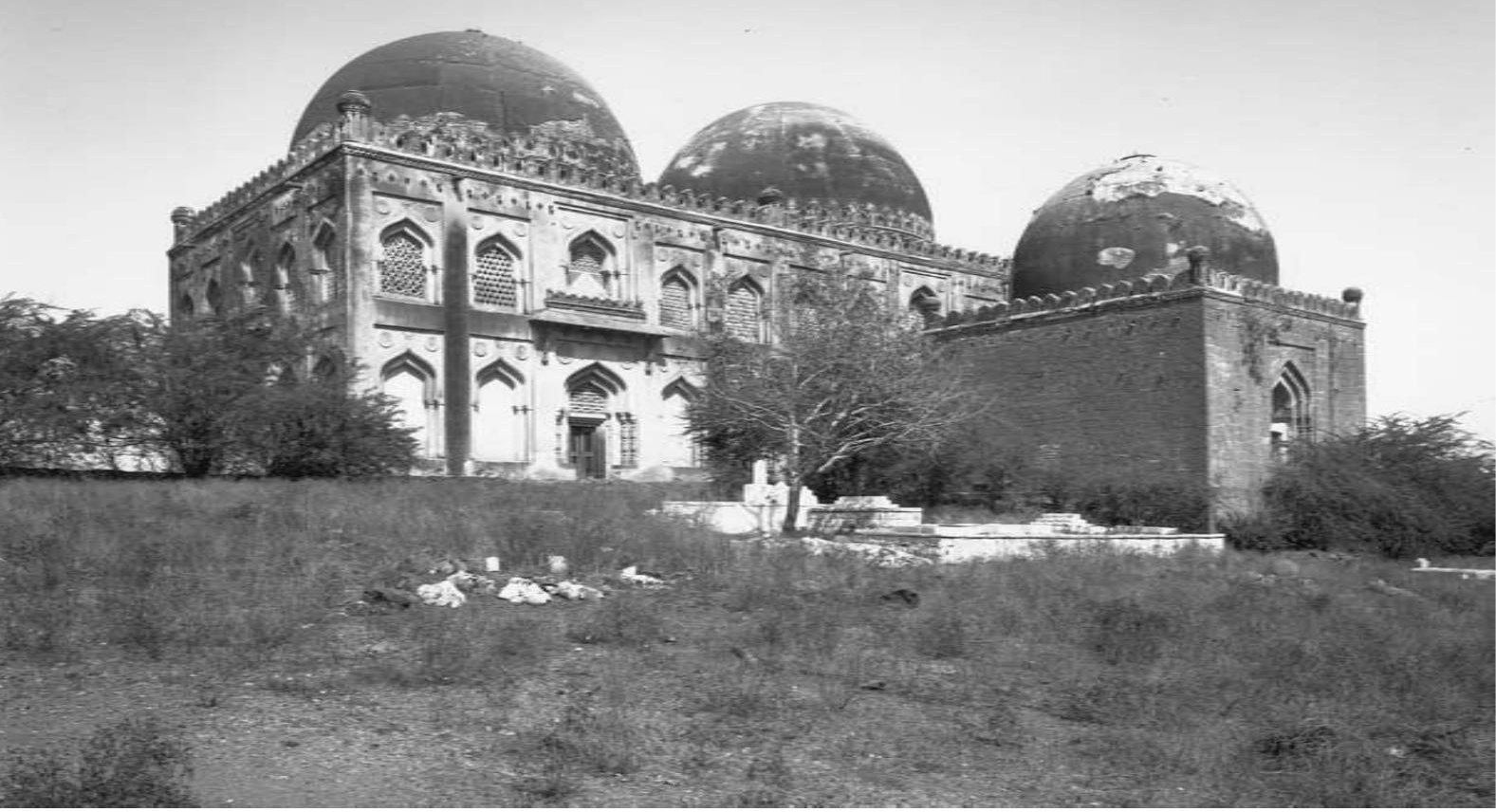

37 Gulbarga, tomb of Fīrūz Shāh Bahman̄̄, c. 823/1420. (Courtesy John Gollings) 


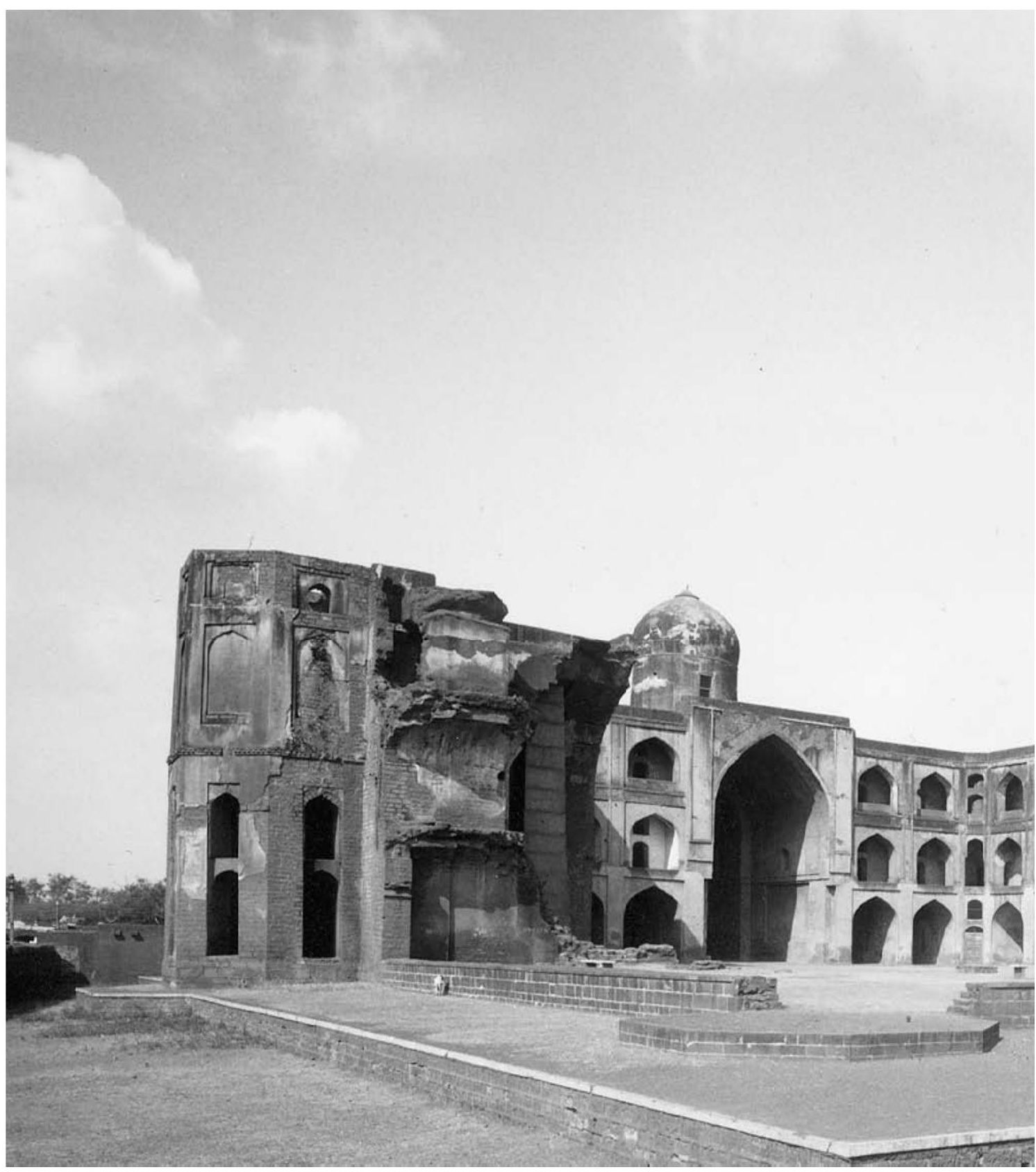

38 Bidar, madrasa of Maḥmūd Gāwān, 877/1472. (Courtesy John Gollings) 


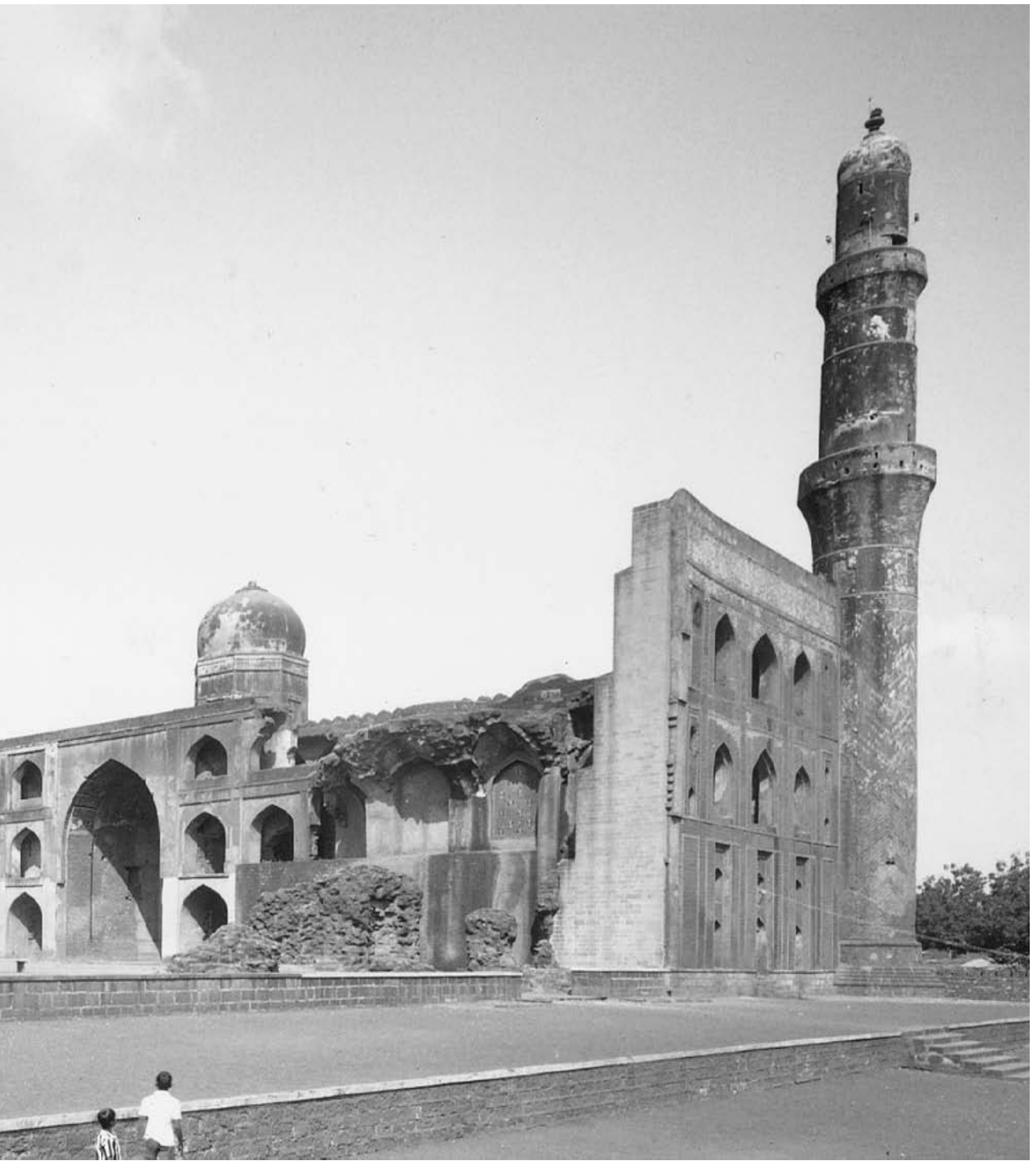




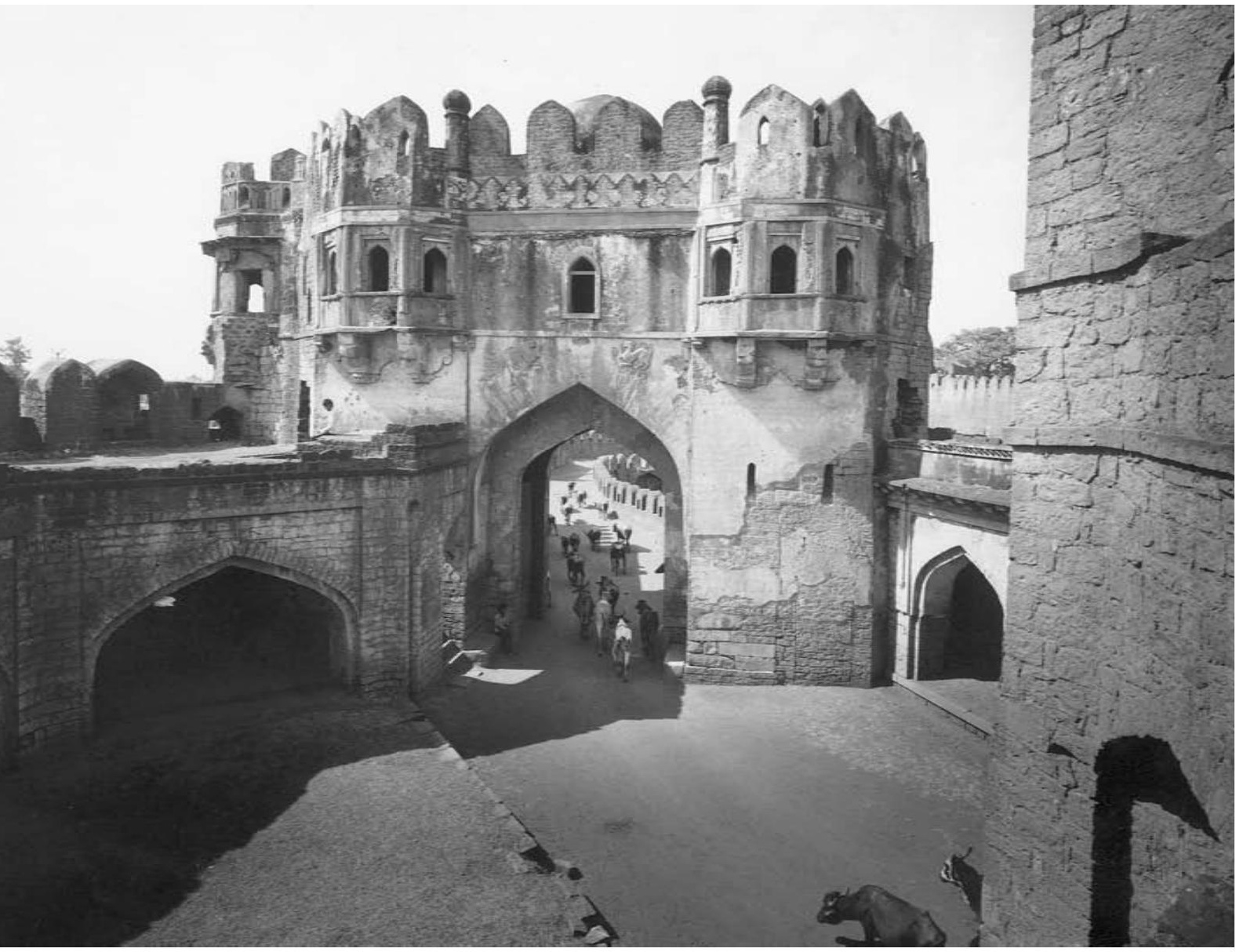

39 Bidar, Sharza Darwāza, early $15^{\text {th }}$ century. (Courtesy John Gollings) 


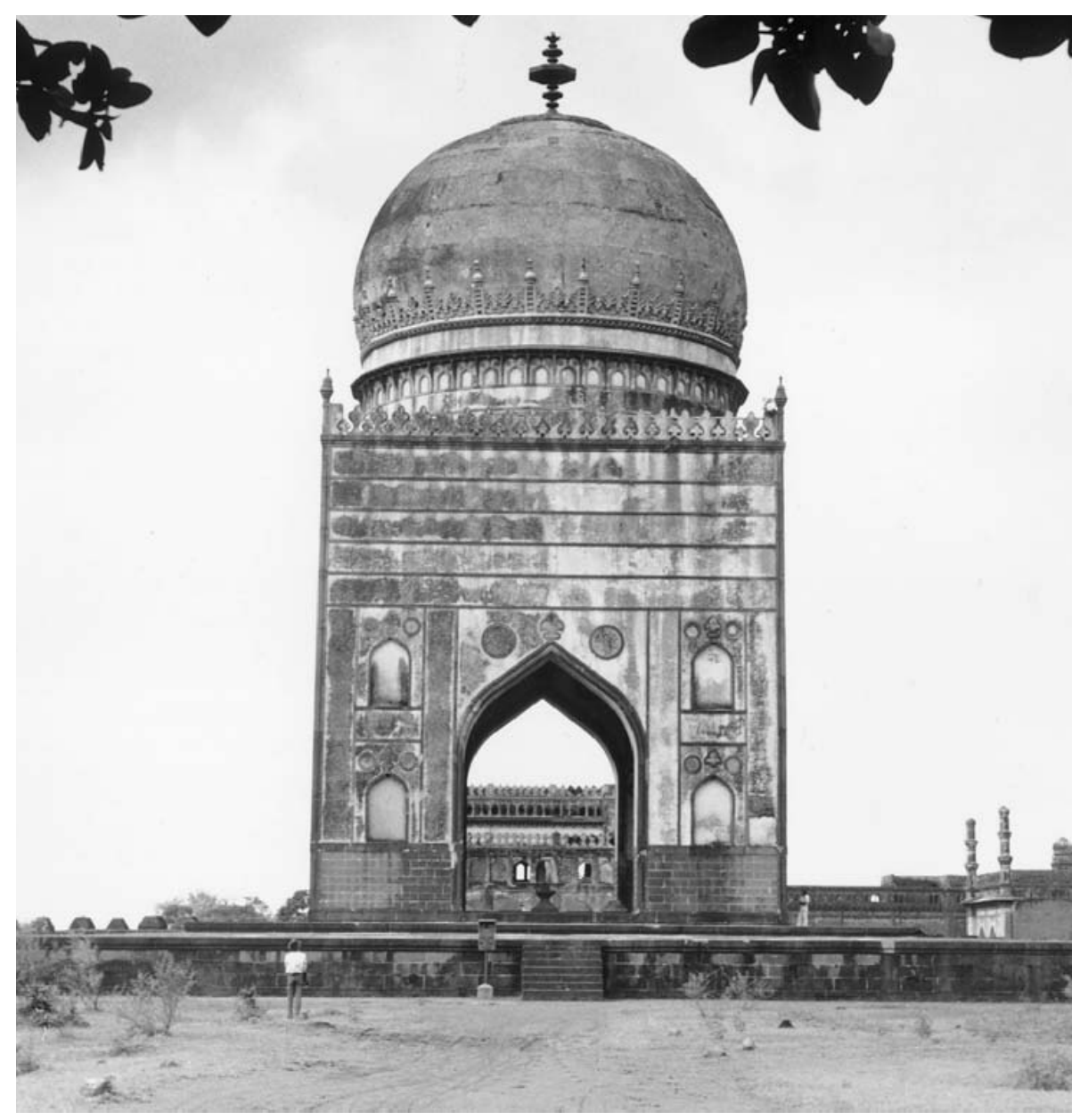

40 Bidar, tomb of 'Alī Barīd, 987/1579. (Courtesy American Institute of Indian Studies) 


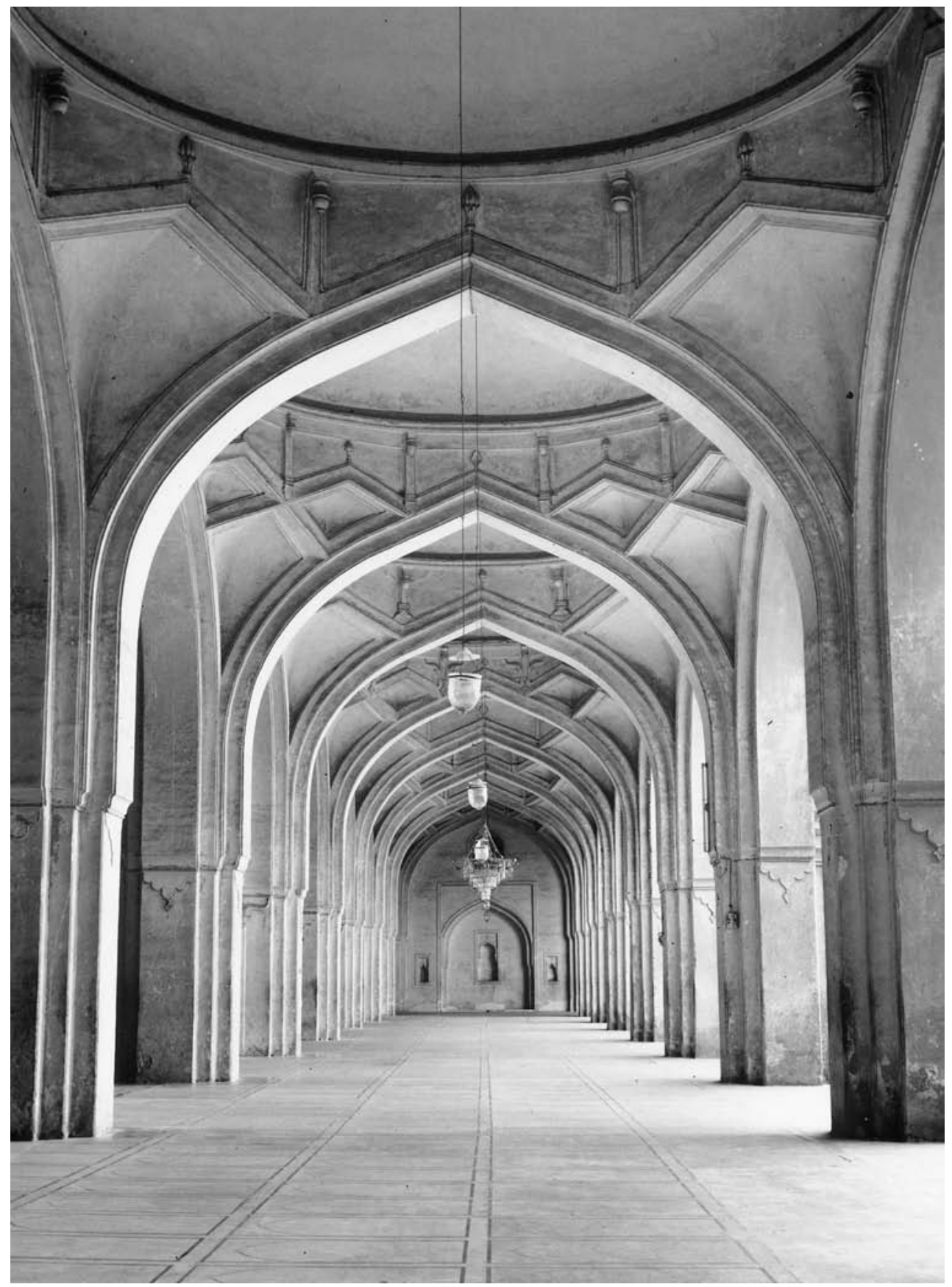

41 Bijapur, Jāmi` Masjid, 985/1576, interior. (Courtesy American Institute of Indian Studies) 


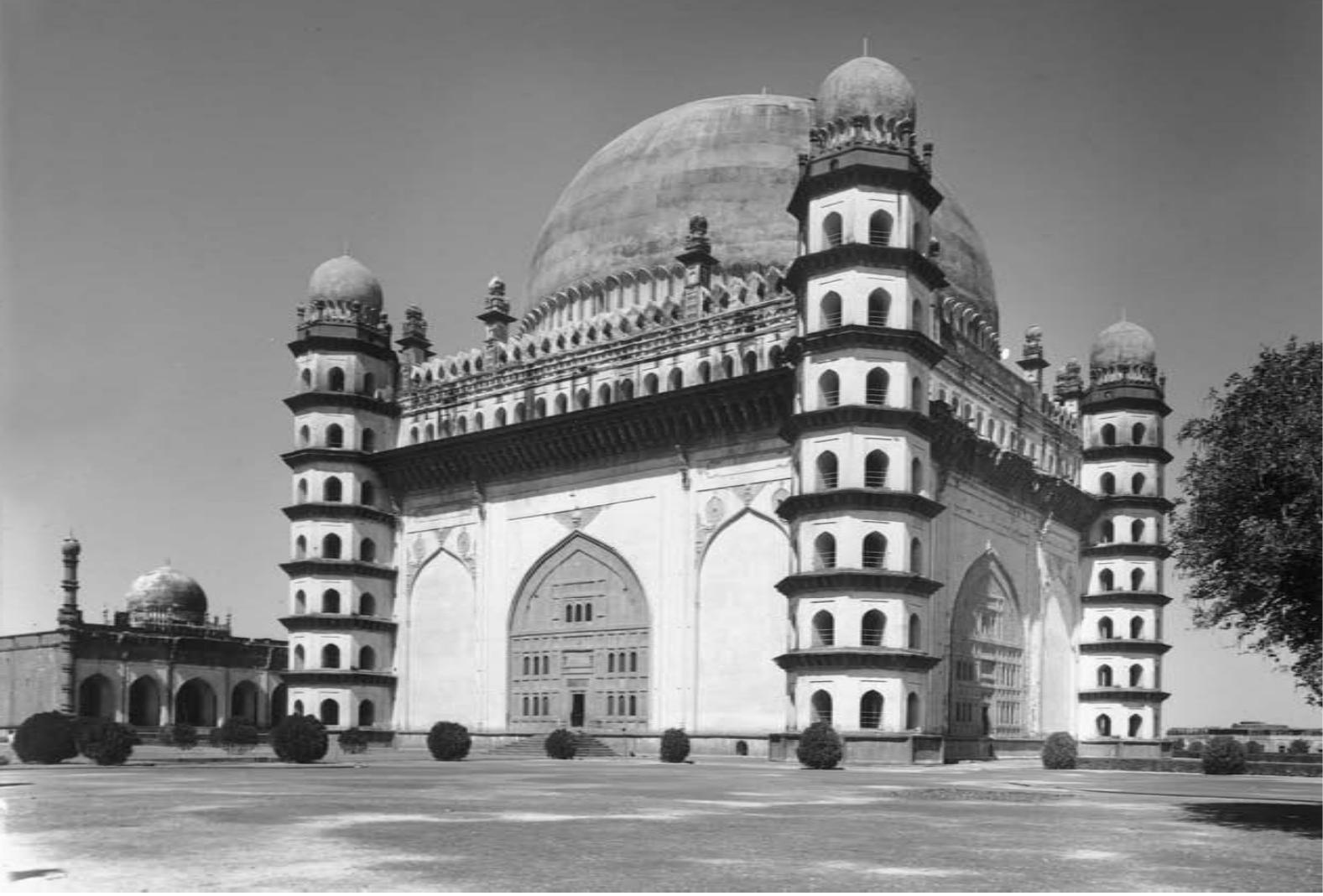

42 Bijapur, Gol Gunbad, 1067/1656. (Courtesy American Institute of Indian Studies) 


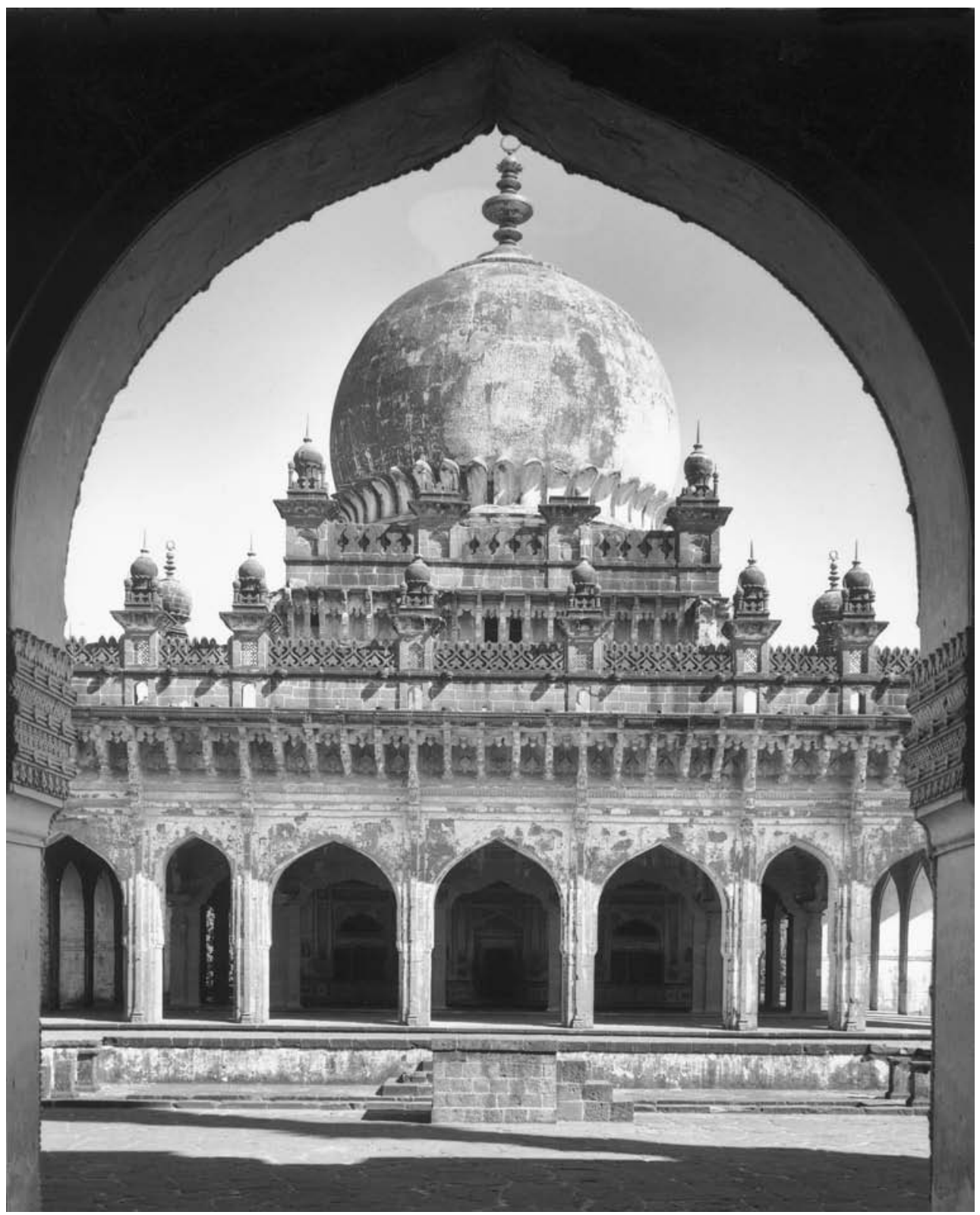

43 Bijapur, Ibrāhīm Rauza, 1036/1626, tomb. (Courtesy American Institute of Indian Studies) 


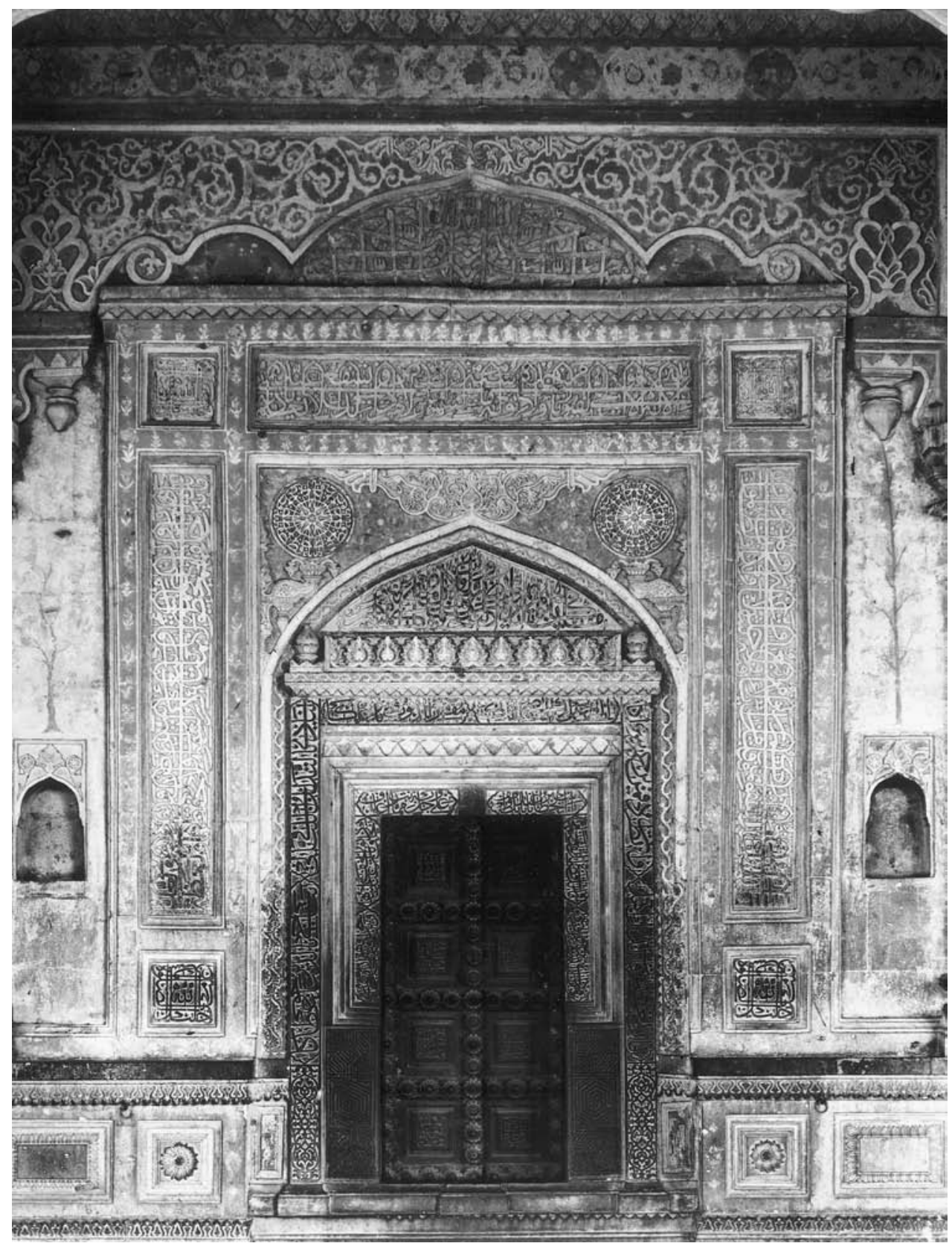

44 Bijapur, Ibrāhīm Rauza, façade detail of tomb. (Courtesy American Institute of Indian Studies) 


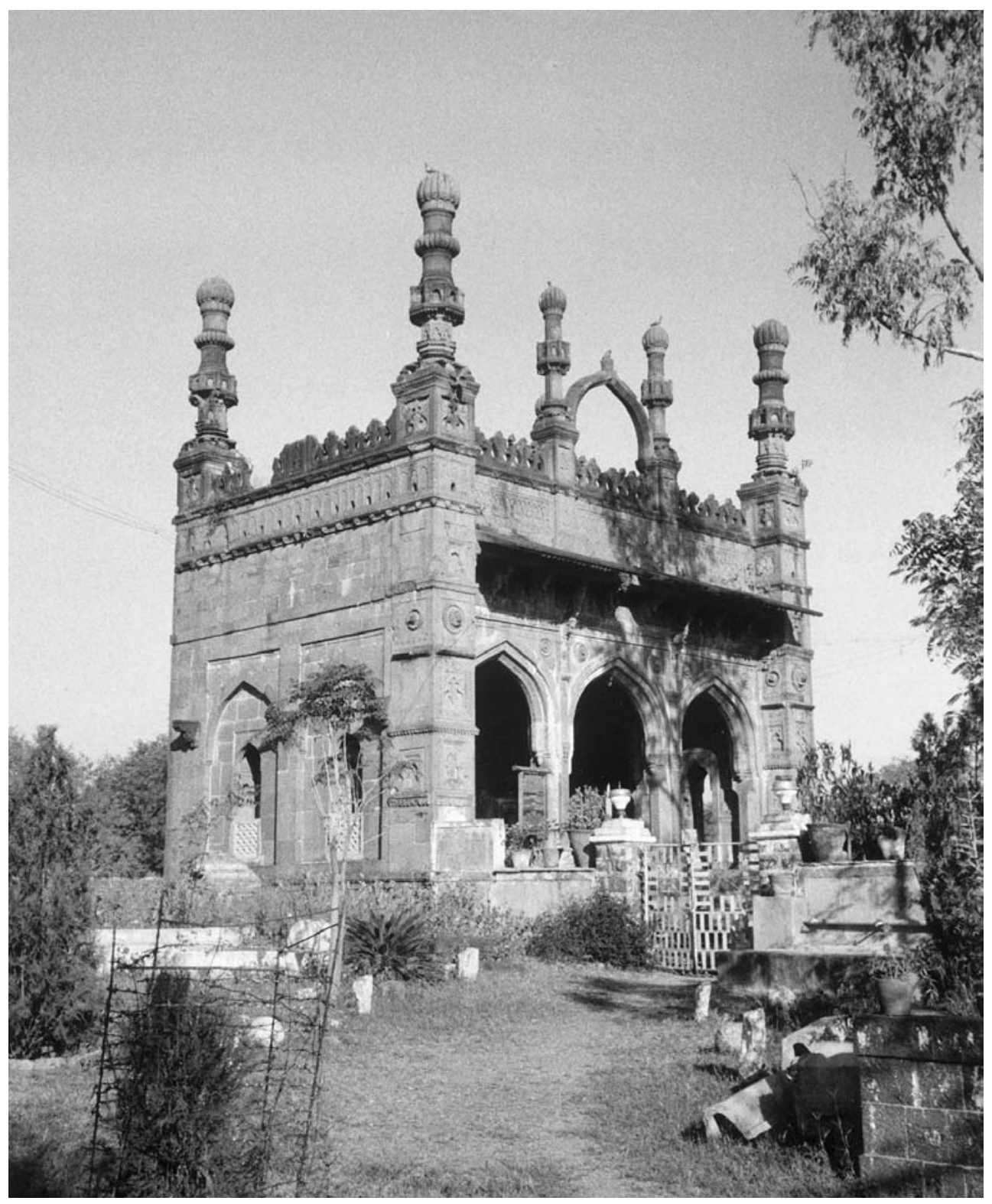

45 Ahmadnagar, Damādi mosque, 976/1568. (Courtesy George Michell) 


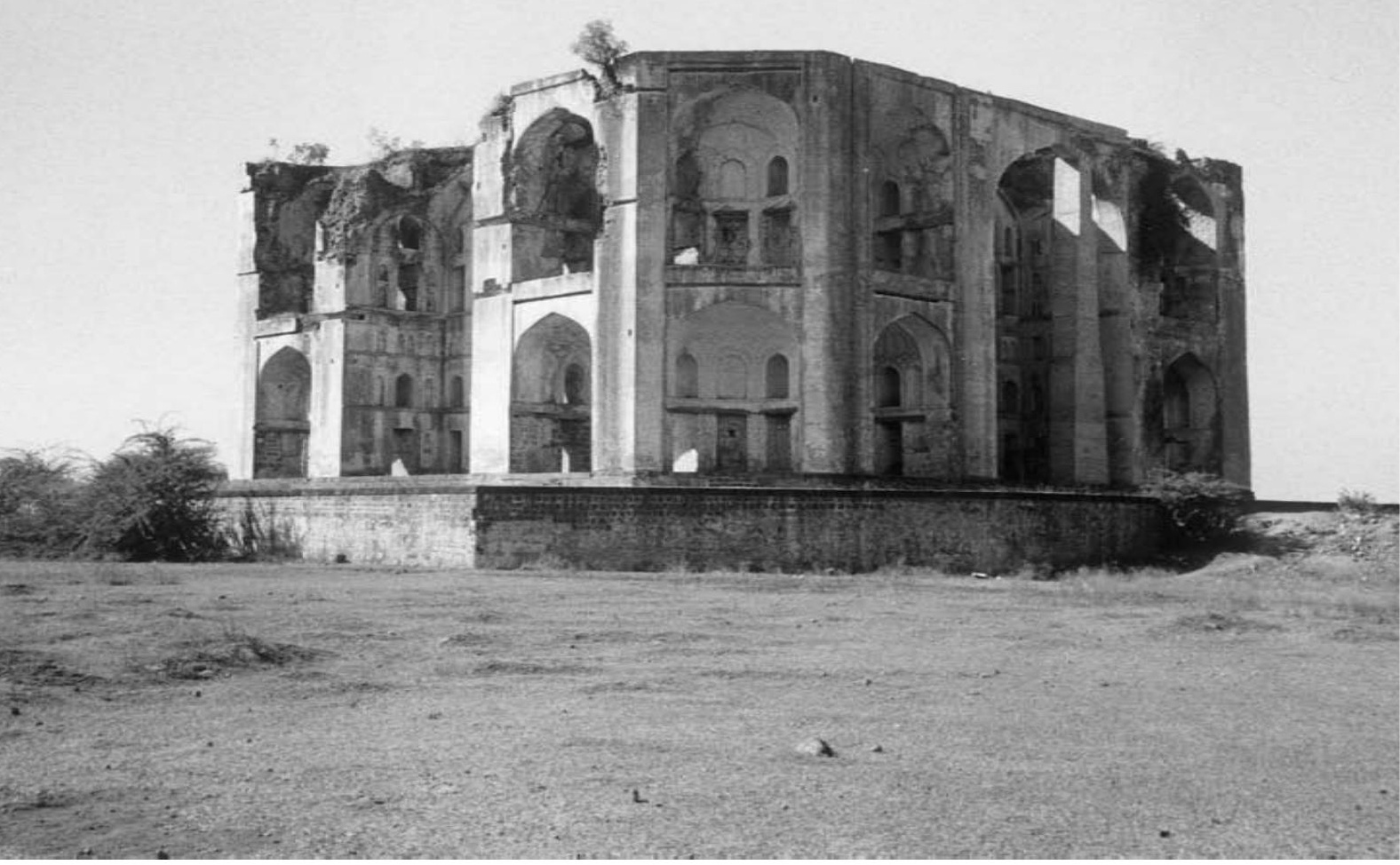

46 Ahmadnagar, Farāh Bakhsh Bāgh, 984-91/1576-83. (Courtesy George Michell) 


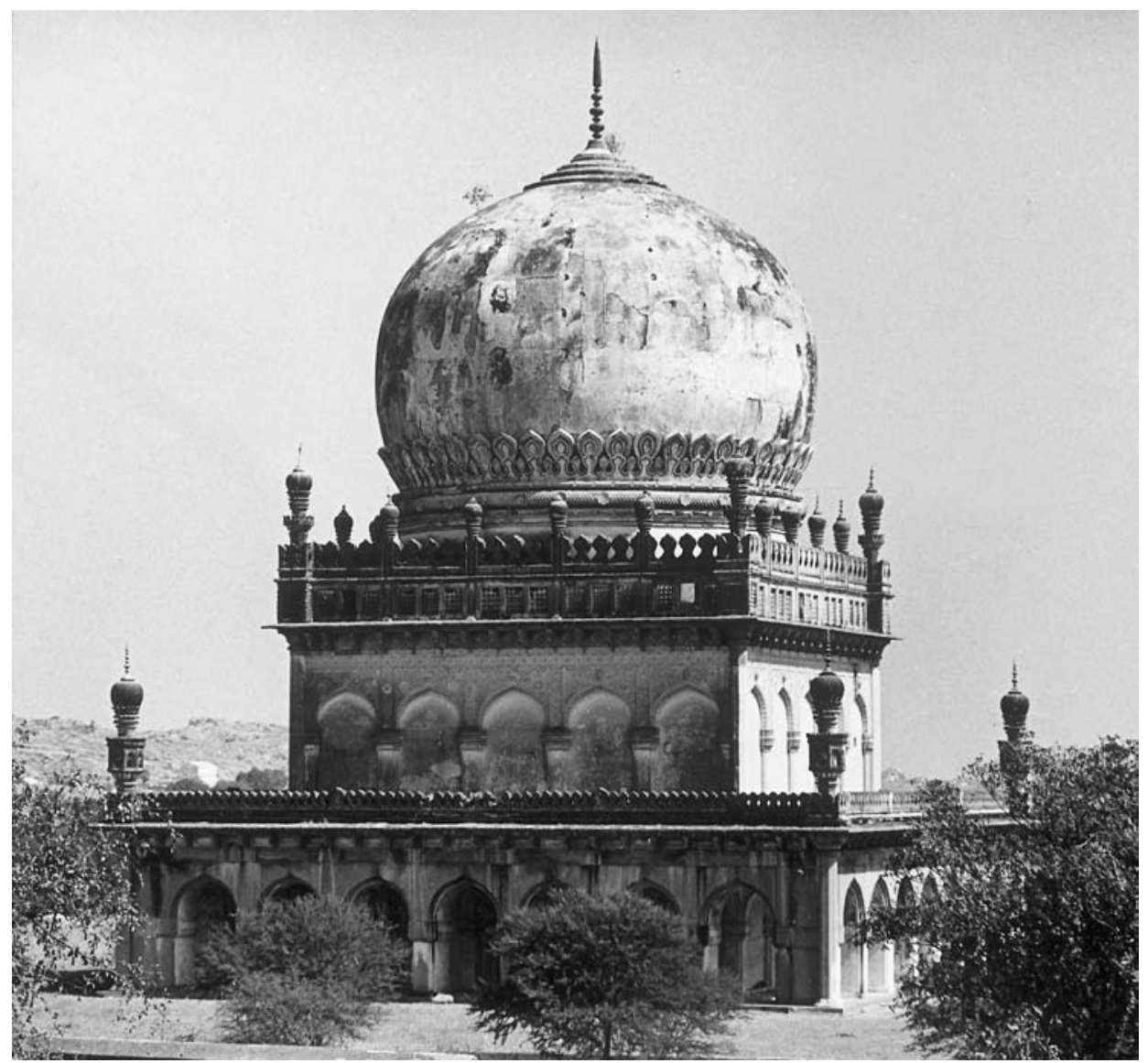

47 Golkonda, tomb of Muhammad Quṭ Shāh, 1035/1626. (Courtesy Estate of Mark Zebrowski) 


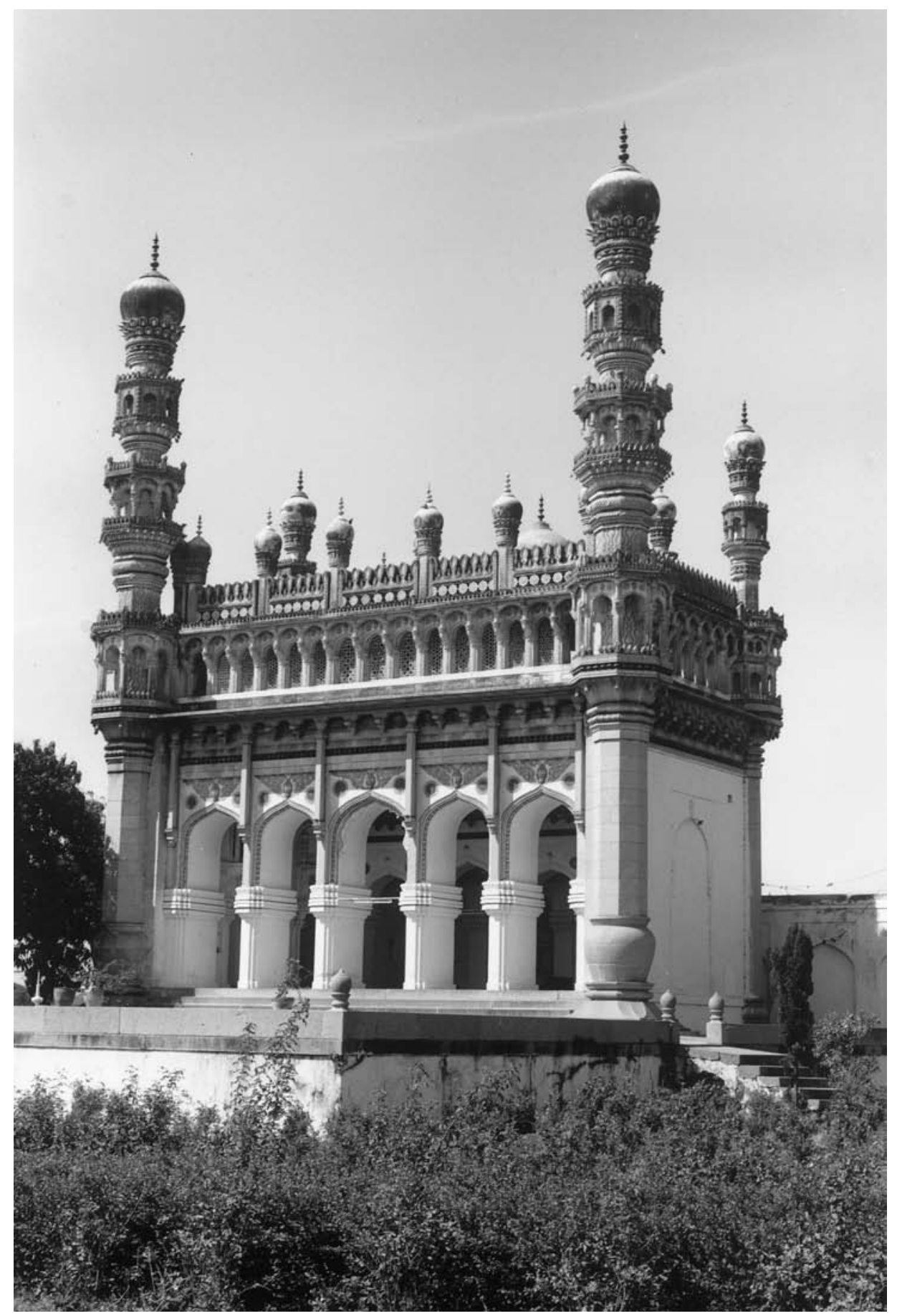

48 Hyderabad, Tōlī mosque, 1082/1671. (Courtesy Estate of Mark Zebrowski) 


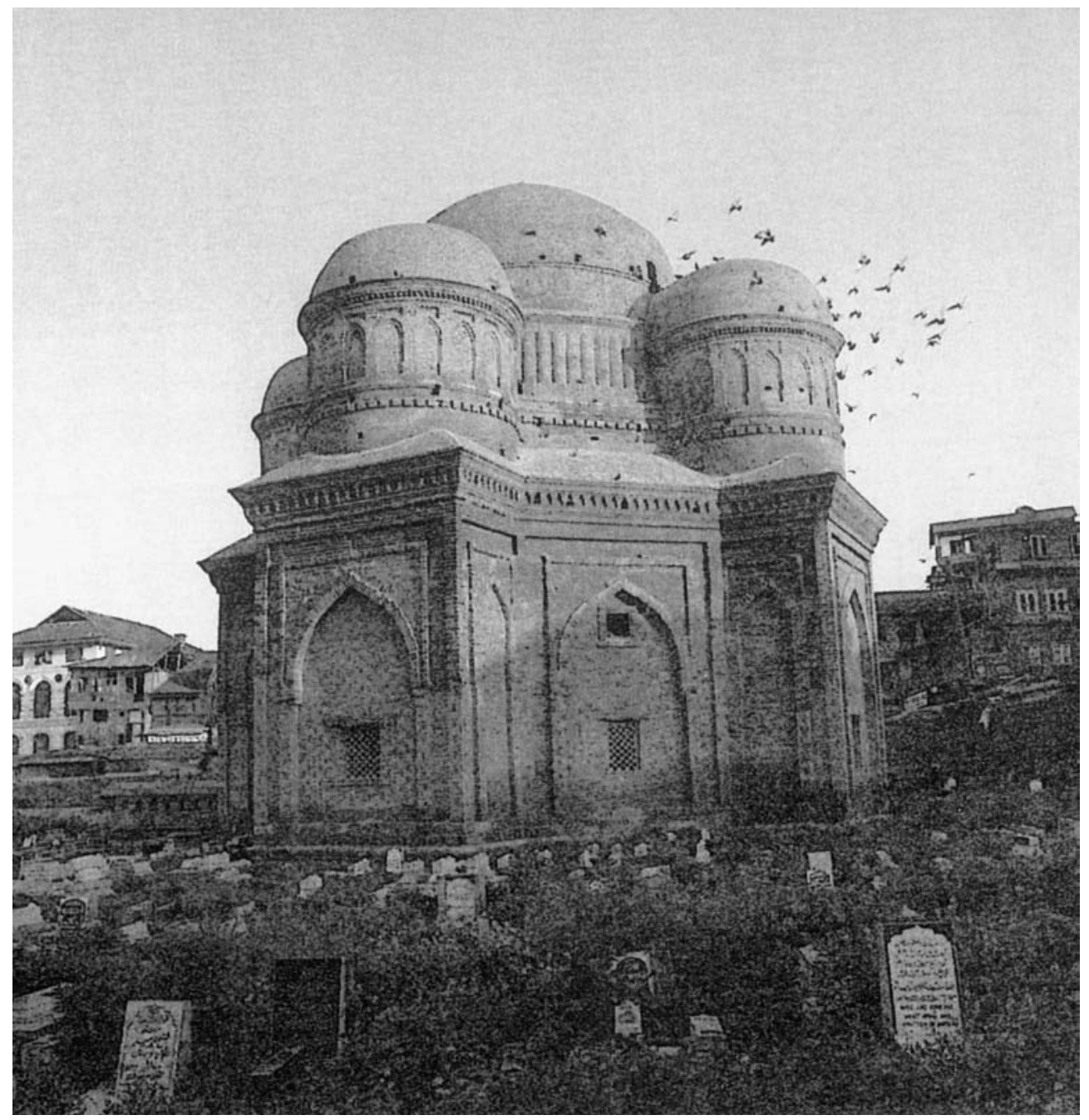

49 Srinagar, tomb of the mother of Sulțān Zayn-al-'Ābidīn, early $15^{\text {th }}$ century. (Courtesy Karoki Lewis and Marg Publications) 


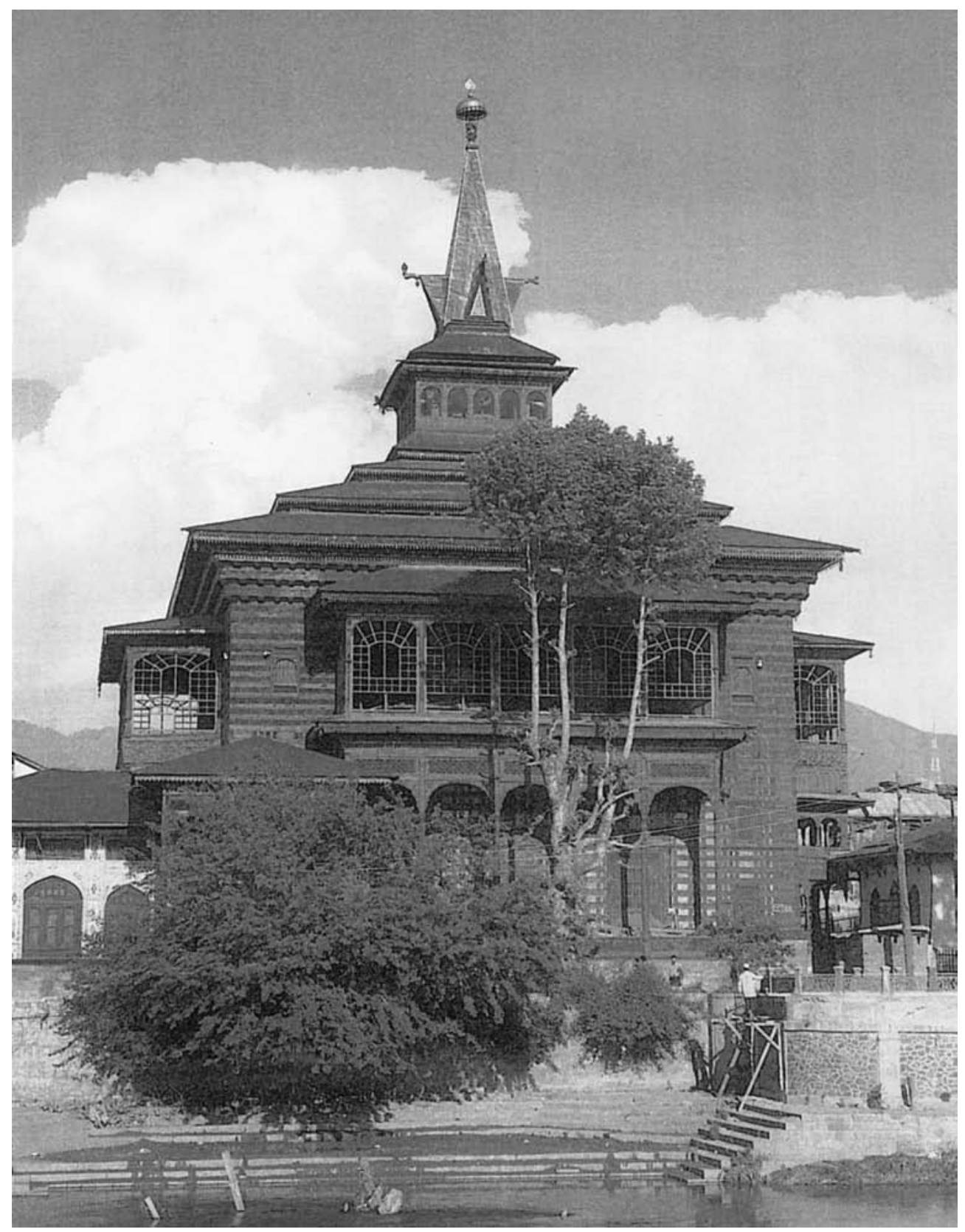

50 Srinagar, Shāh Hamadān mosque, $15^{\text {th }}$ century. (Courtesy Karoki Lewis and Marg Publications) 


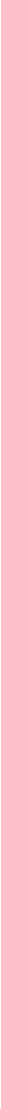

51 Delhi, Purānā Qil'a, c. 947-62/1540-55, west gateway. (Courtesy American Institute of Indian Studies) 


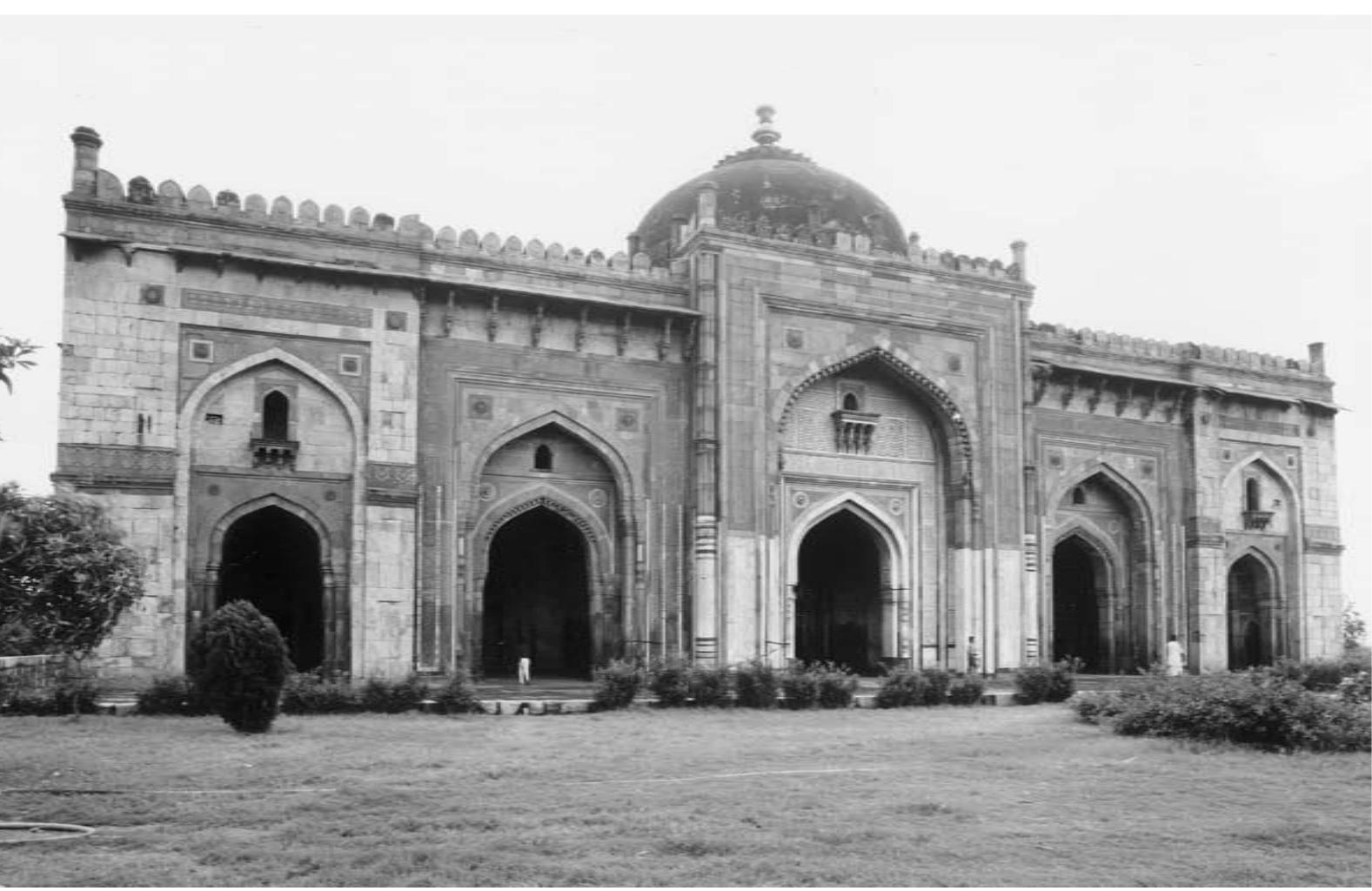

52 Delhi, Qil'a-i-Kuhnā Masjid, 948/1541. (Courtesy American Institute of Indian Studies) 


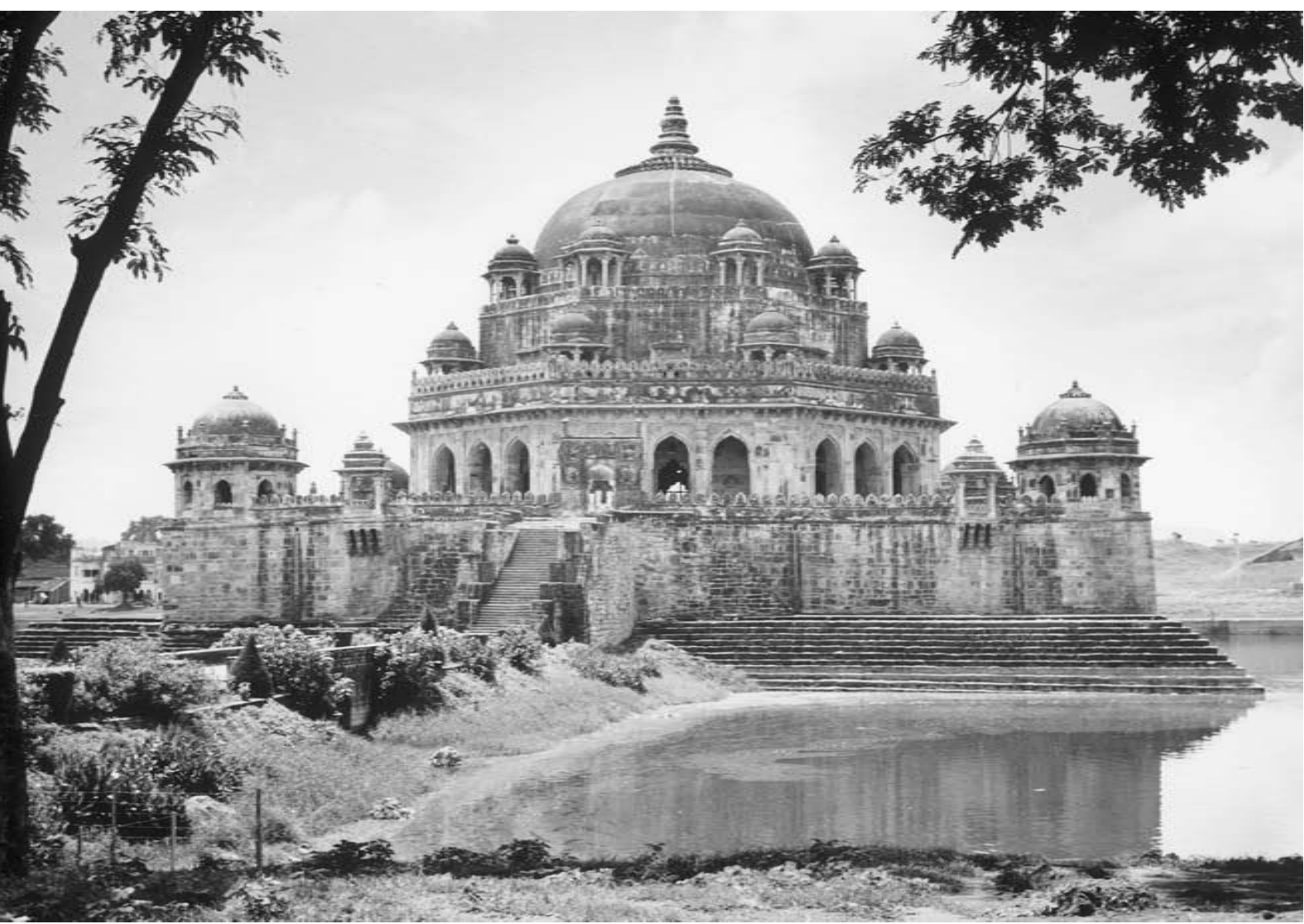

53 Sasaram, tomb of Shēr Shāh Sūrī, c. 952/1545. (Courtesy American Institute of Indian Studies) 


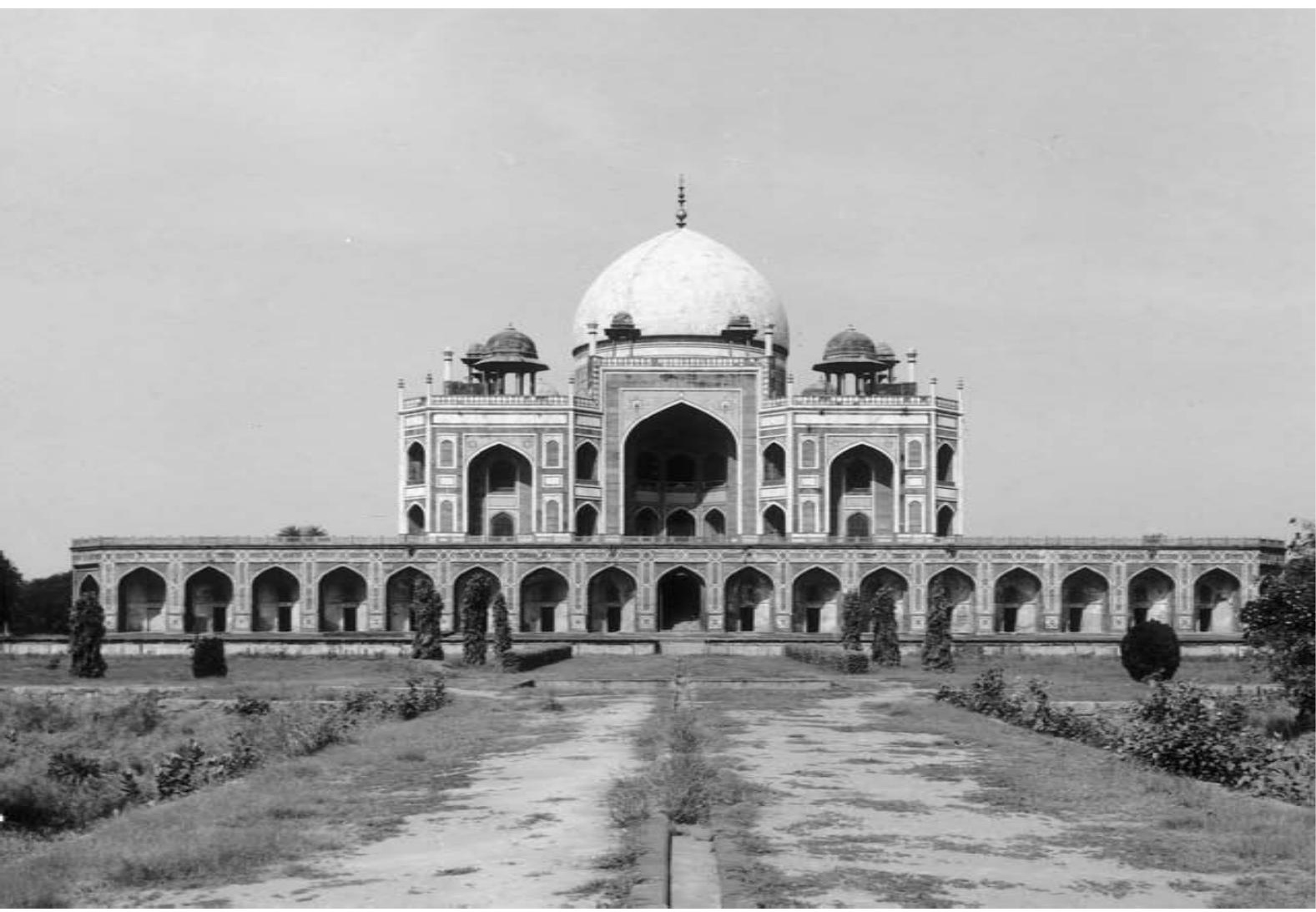

54 Delhi, tomb of Humāyūn, begun 976-8/1588-9. (Courtesy American Institute of Indian Studies) 


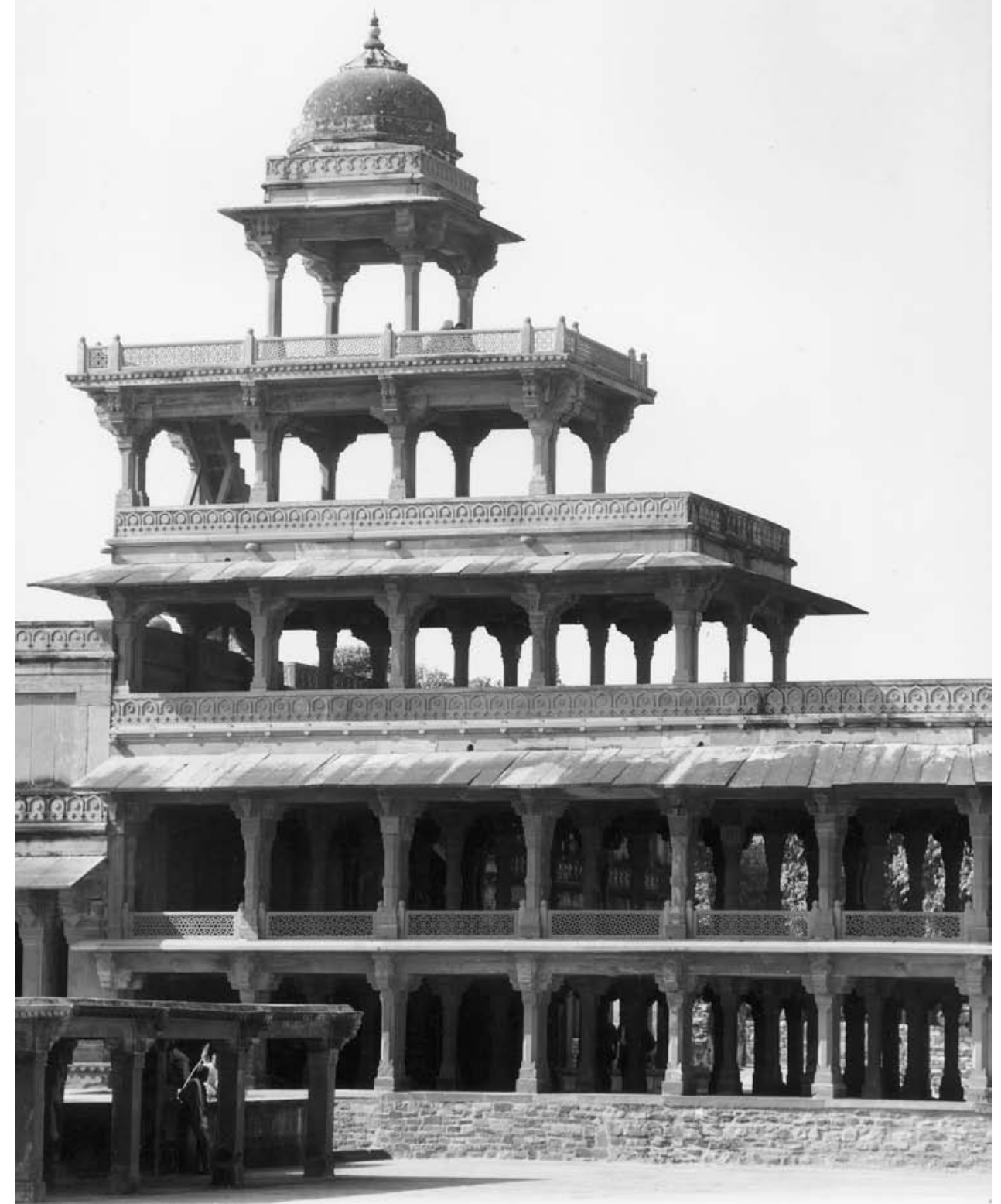

55 Fatehpur Sikri, Pānch Maḥall, c. 970s/1570s. (Courtesy American Institute of Indian Studies) 


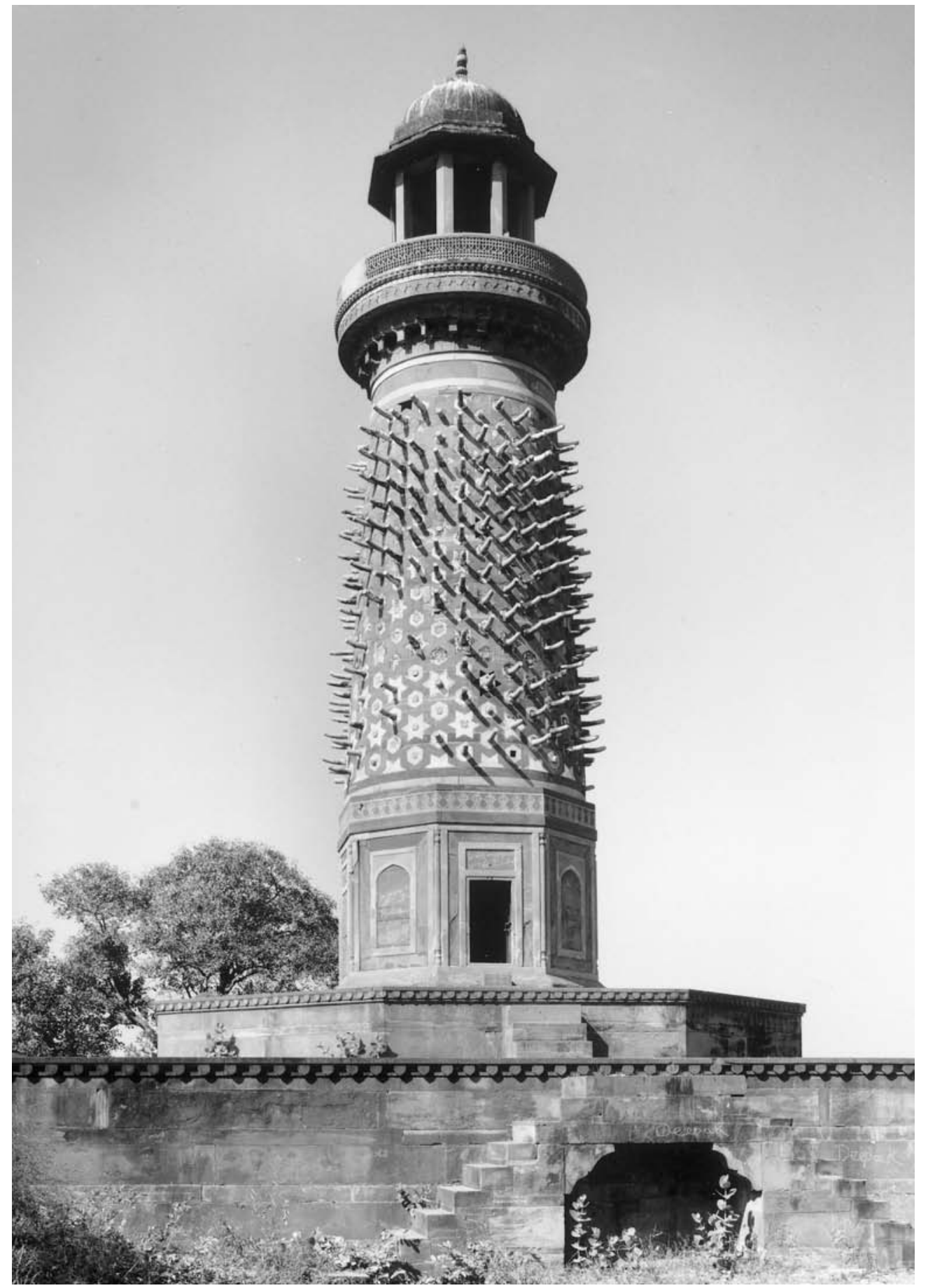

56 Fatehpur Sikri, Hiran Mīnār, 970s/1570s. (Courtesy American Institute of Indian Studies) 


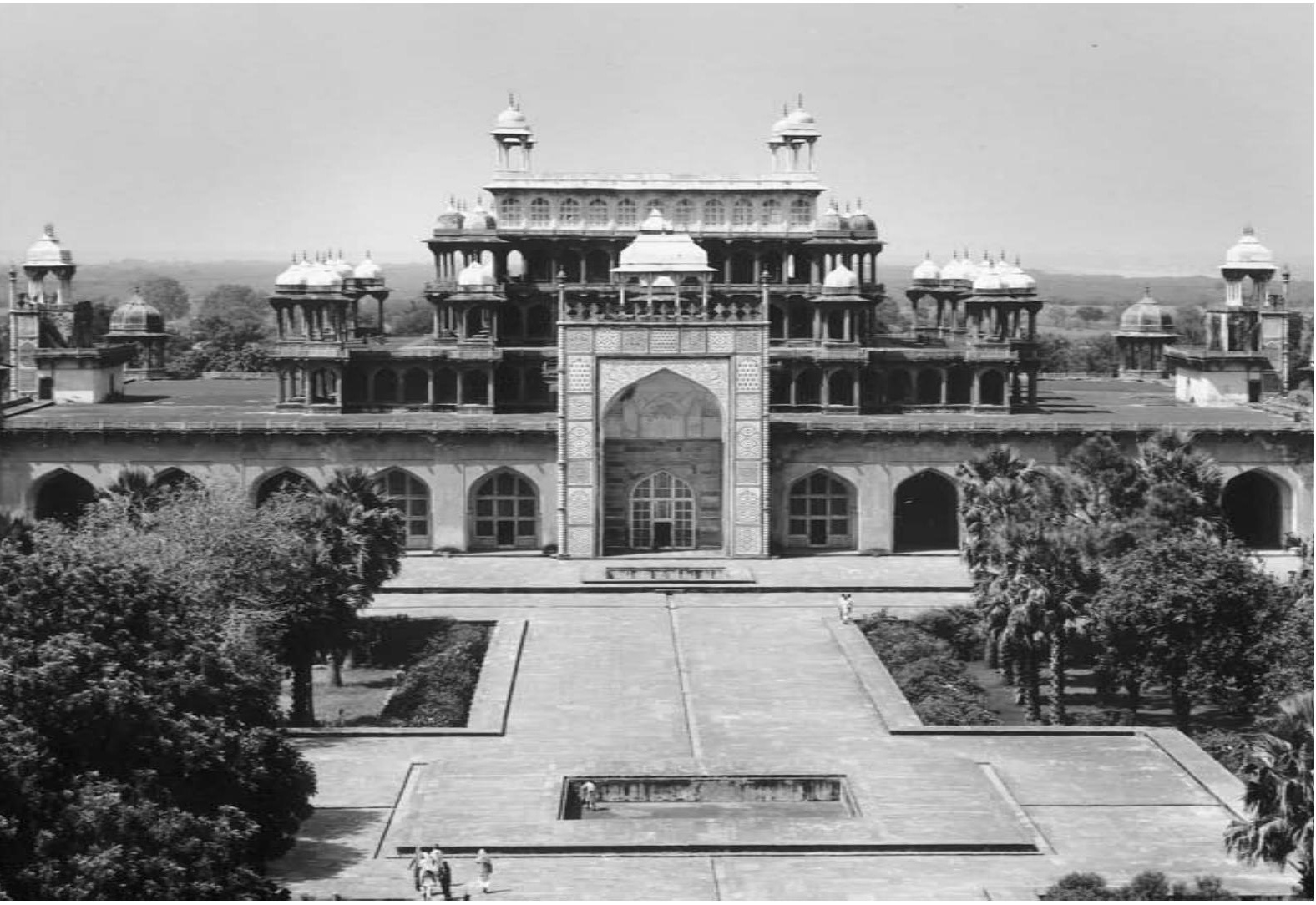

57 Agra, tomb of Akbar at Sikandra, 1022/1613. (Courtesy American Institute of Indian Studies) 

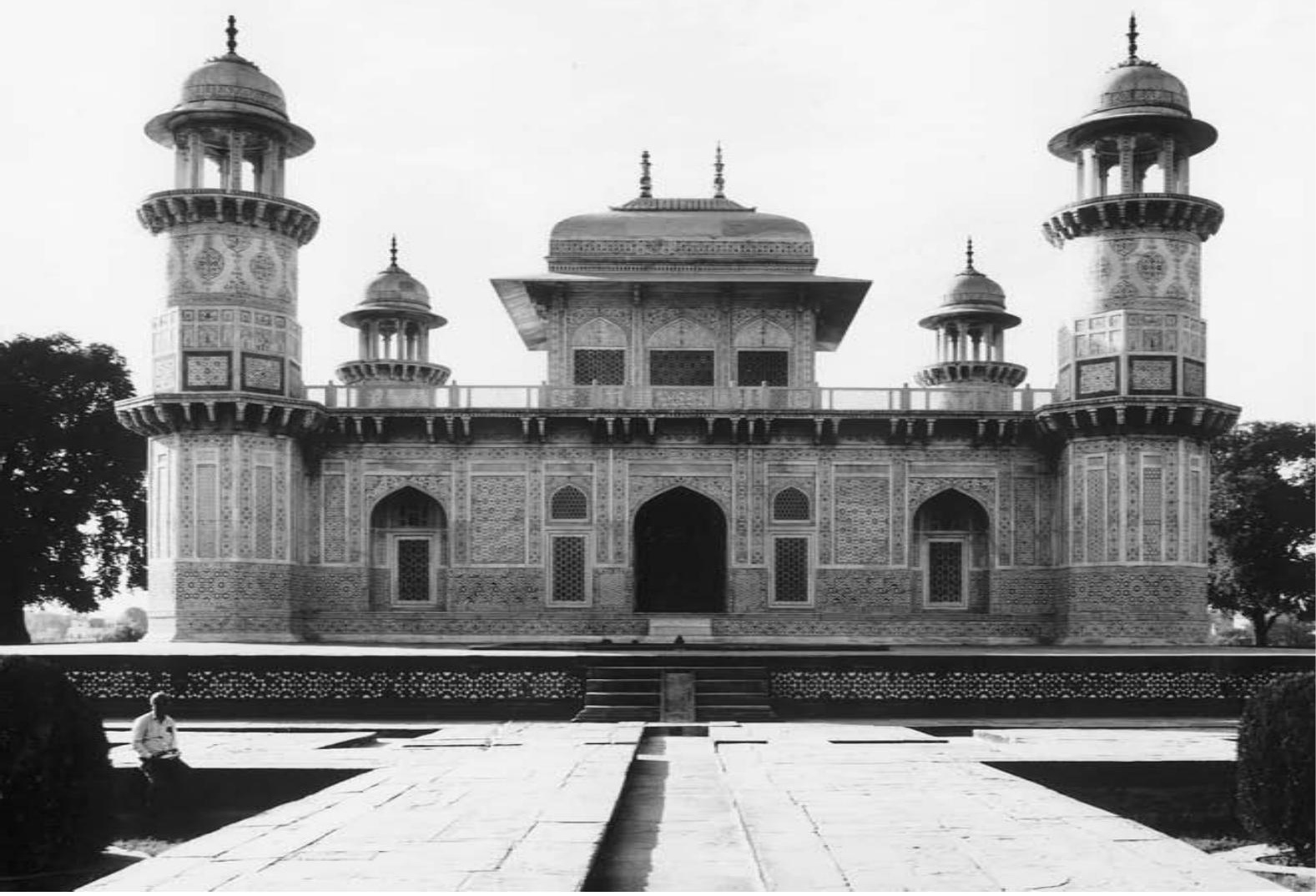

58 Agra, tomb of I'timād ad-Daula, 1036-7/1626-8. (Courtesy American Institute of Indian Studies) 


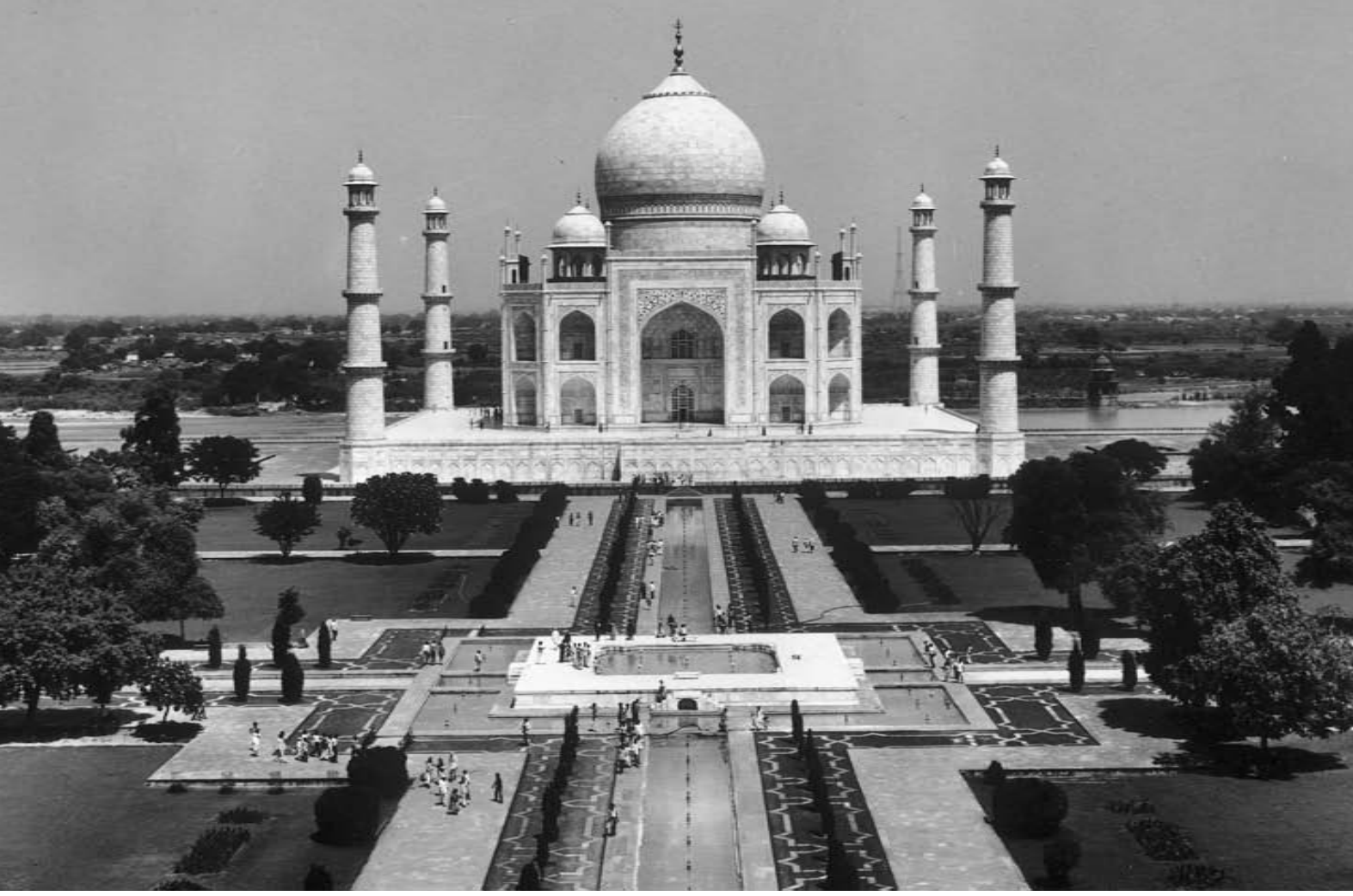

59 Agra, Tāj Maḥall, 1041-52/1632-43. (Courtesy American Institute of Indian Studies) 


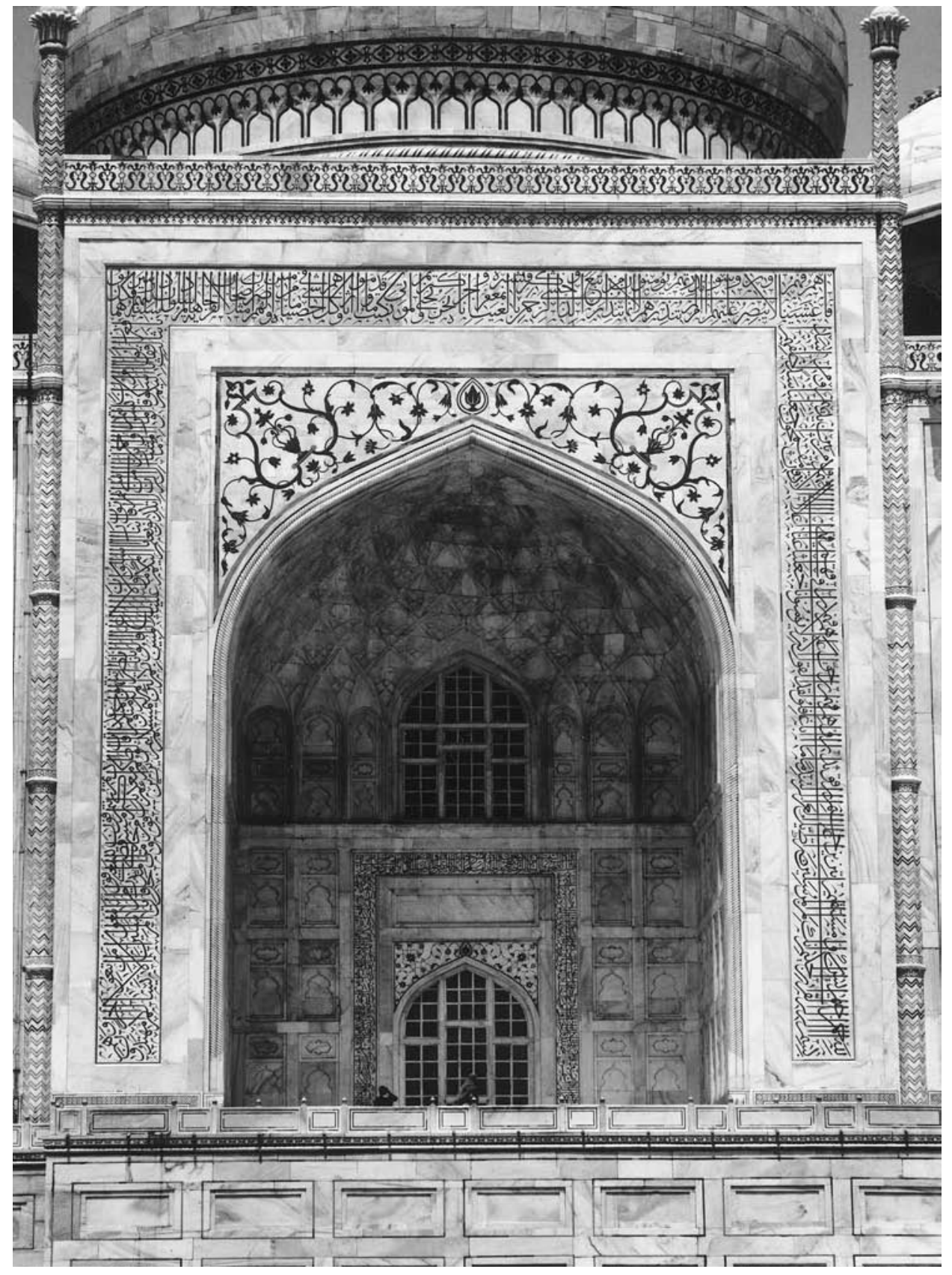

60 Agra, Tāj Maḥall, south portal. (Courtesy American Institute of Indian Studies) 


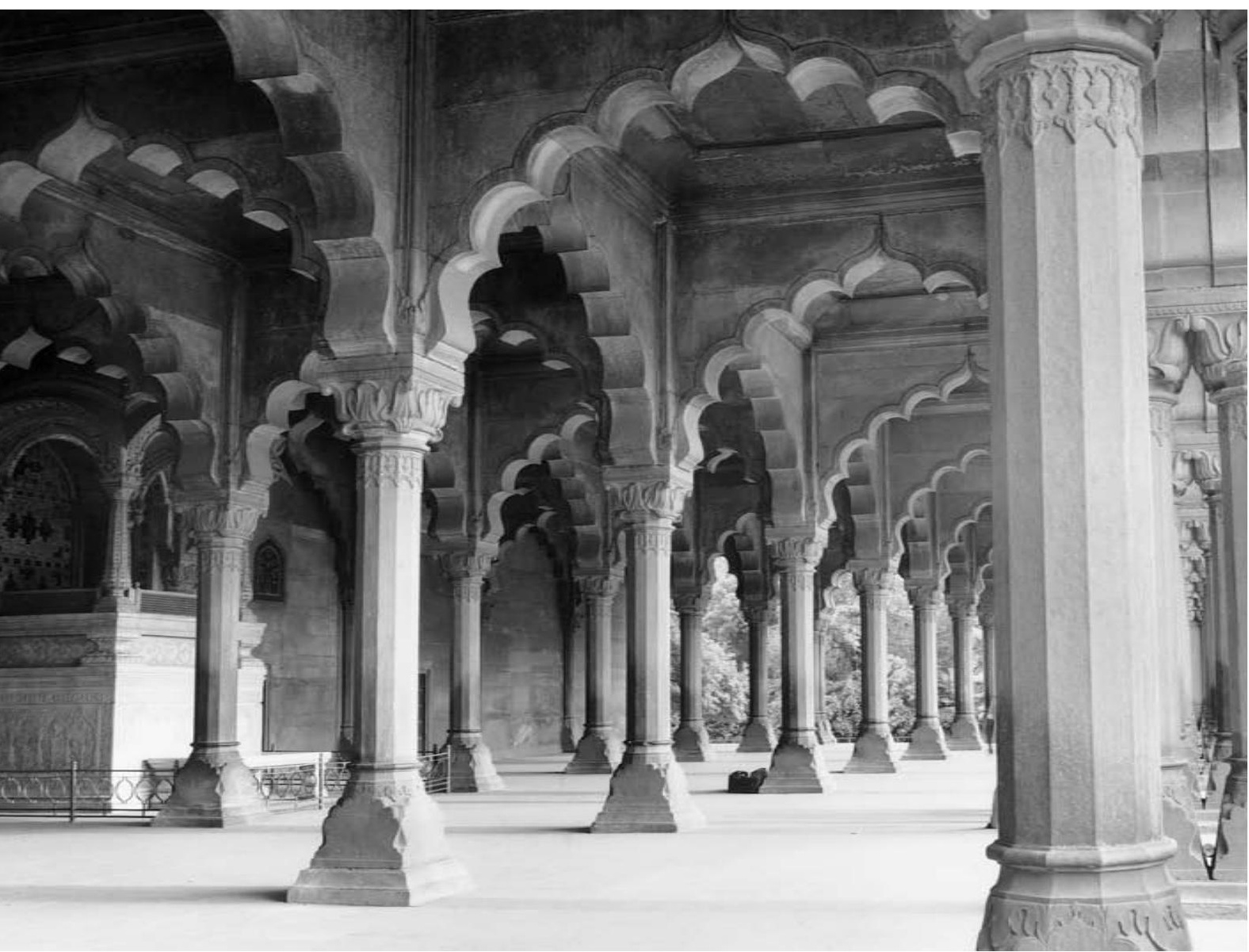

61 Delhi, Lāl Qil'a, 1048-58/1639-48, Dīwān-i Āmm. (Courtesy American Institute of Indian Studies) 


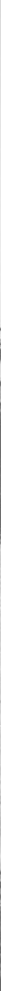

62 Agra, Jāmi 'Masjid, 1060-66/1650-56. (Courtesy American Institute of Indian Studies) 


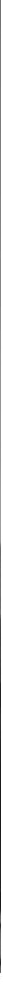

63 Aurangabad, tomb of Rābi'a Daurānī ("Bībī kā Maqbara"), 1071/1661. (Courtesy George Michell) 
FORMS AND TYPOLOGIES 


\section{MosQues*}

The continuous history of the mosque begins with the Masjid Quwwat al-Islām in Delhi, founded immediately after the Muslim conquest in $587 / 1191$. There are however records of mosques founded earlier, e.g. under the 'Abbāsid Caliphate in Sindh, by small communities of Muslim traders, especially in Gujarat and the Malabar coast, and by individual Sūfi pìrs who gathered a community around them. The remains of these are mostly too exiguous to be of value in a general statement. Recent explorations by M. Shokoohy have revealed a few structures, of a century or two before the conquest, at Bhadreshwar in Gujarat. These, in common with the first structures of any fresh conquest of expansion, are constructed from the remains of Hindu buildings; in the case of mosques built after a conquest there has been a deliberate pillaging of Hindu or Jain temples, as an assertion of superiority as well as for the expediency of making use of material already quarried and of local impressed labour before the arrival of Muslim artisans. (It should be pointed out that the practice of pillaging the buildings of the conquered is known in India in the case of rival Hindu kings also.)

Where a mosque is actually constructed on the plinth of a destroyed Hindu building (e.g. Masjid Quwwat al-Islām at Delhi; Atalā Masjid at Jaunpur) the qibla will probably not be accurately located and the original cardinal west made to serve the purpose; but in general an effort is made to observe the correct qibla, which varies between $20^{\circ}$ north of west in the south of India to $25^{\circ}$ south of west in the extreme north, with a conventional west used only rarely in original buildings.

Mosques which might be described as "public"-i.e., not only the masjid-i jämic of a particular locality (and of course in a conurbation

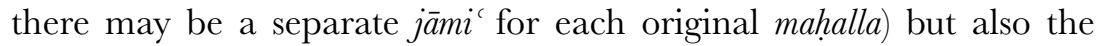
individually-founded or endowed mosques within a town - are enclosed on all sides. This has not been required of mosques within a sara $\bar{\imath} \bar{\imath}$ or a dargāh, or when the mosque is an adjunct of a tomb, and there are countless instances of small private mosques where there seems never to have any enclosure. The enclosure for the public mosque is particularly necessary for Islam in partibus infidelium, and those courtyards which are

\footnotetext{
* “Masjid, ii. In Muslim India, A. Typology,” EI, VI. 688-90.
} 
not enclosed are protected from the infidel gaze in some other way, e.g. by the sahn standing on a high plinth (examples: the Jāmi ' Masjid at Shāhjahānābād, Delhi, and the Atalā Masjid at Jaunpur, where in both the courtyard is limited only by an open arcade or colonnade). The principal entrance is usually on the east, although any gate may be on occasion specified as a royal entrance; it is rare, though not unknown, for any entrance to be made in the western wall, and where this has happened it is not designed for access by the general public. The internal position of the principal mihrāb, sometimes of subsidiary mihrābs also, is indicated on the outside of the west wall by one or more buttresses; a feature of mosques in India is the way the exterior elevation of the west wall is brought to life by decorative expedients.

The interior of the mosque admits of little variation outside two well-defined types. In one the western end (known in India as lizwān) is a simple arrangement of columns supporting a roof, usually of at least three bays in depth but possibly of many more; the roof may be supported by beam-and-bracket or by the arch; the former arrangement being by no means confined to compilations of pillaged Hindu or Jain material. The liwañ openings may be connected directly with the arcades or colonnades of other sides of the sahn. Where Hindu material has been used it is usually necessary to superimpose one column upon another in order to gain sufficient height, for not infrequently a mezzanine gallery may be incorporated in the structure, in the liwe $\bar{a} n$ or in the side riwäqs. These are frequently referred to as "women's galleries", but this is surely impossible unless they are placed to the rear of the structure so that women may not make their prayers in front of men; gallery structures in the tīwann are more likely to be either reserved for royal (male) use or to be chillas for the use of a local pir. In the other type, the lizwan is physically separated from the șahn by a screen of arches (maqșüra), which may conceal a columnar structure to the west, as in the Masjid Quwwat al-Islām where the maqsüra is a later addition to the original structure, or in the mosques of Gujarat where the arch is not used with as much freedom as in other styles. More commonly, however, the arches of the maqșura are part of a vaulting system whereby the tiw $\bar{a} n$ is composed into one or more halls; there is always an odd number of maqsüra arches, and it is common for the bay which stands in front of the principal mihrāb to be singled out for special treatment, either by being made taller than the rest, or by being specially decorated (the latter treatment common in the 
mosques of Bijapur). (This is not invariably the central bay, as mosques are not necessarily symmetrical about the principal mihrāb axis; cf. the "Stonecutters' mosque" in Fatehpur Sikri, where a chilla occupies two additional bays at the north end of the līwān, or the Arhā'i Kangūra Masjid at Banaras (Varanasi), where the side riwāqs of the tiw wann are of unequal length.) In one mosque at Bijapur (Makkā Masjid), the tìwān stands within and unattached to the surrounding courtyard. A staircase is commonly provided to give access to the tìwan roof, either separately or incorporated within the walls or the base of a minaret, as this is a favourite place from which to call the $\bar{a} d h \bar{a} n$; a staircase may be provided within a gateway for the same purpose. The tìwann roof may be surmounted by one or more domes.

Inside the liwwann, the principal mihrāb stands within the west wall opposite the main opening; if there are other mihräbs, the central one is always the most sumptuously decorated and may be set deeper within the west wall than the other. The minbar is usually a permanent stone structure, with an odd number of steps, only occasionally made an object of decoration (splendid examples in the older Bengal mosques and in the Malwa Sultanate). A simple minbar is often provided when not liturgically necessary, as in the mosque attached to a tomb. There is an exceptional case at Bijapur, at the mosque building for the cenotaph of Afzal Khān: the mosque is two-storeyed, the two halls being exactly similar except that a minbar is provided only in the lower one. (In another first-floor mosque at Bijapur, the Andā Masjid, there is no minbar; the ground floor is apparently a well-guarded sara $\bar{\imath} \bar{\imath}$, and the suggestion has been made that the whole structure was intended for zanāna use.) The floor of the tìwān is often marked out into musallās of mihräbi shape for each individual worshipper. Lamps may be suspended from the tīwān ceiling. The tīwan façade is open to the șahn; i.e. there is never any portion closed off like the zimistān of Persian mosques.

The șahn is usually an open courtyard, containing a hauz for the wuz $\bar{u}$; this is usually placed centrally, except that in some Shīi mosques the hauz may be placed to one side of the central axis. There are rare cases where the șahn is completely or partially covered (e.g. the Jāmi' Masjid at Gulbarga is completely covered; in two mosques of the Tughluq period at Delhi, Khirkī Masjid and Sanjar (Kālī) Masjid, additional riwāqs leave only four small open courtyards in the middle of the sahn). In such cases provision must be made for the $w u z \bar{u}^{\prime}$ outside the sahn; some major mosques may also make provision, outside the șahn, for the 
ghusl. In some Gujarat mosques there is a water reservoir under the floor of the sahn, sometimes with chambers wherein to take refuge from the heat of the sun, with some sort of kiosk standing in the șahn from which water may be drawn; the idea is imitated on a small scale in the floor of the Jāmi 'Masjid in Fatehpur Sikri. In one complex (Rājōn kī bā' īn) south of the Masjid Quwwat al-Islām the mosque and an associated tomb seem subordinate to an enormous step-well $(b \bar{a}) \hat{\imath} \bar{\imath})$.

One or more bays of the side or end riwāqs may be closed off for a special purpose, e.g. to make a room for relics, or to serve as a room for the $q \bar{a} d \bar{\imath}$ or mutawalli ; in Shî'i mosques, sometimes to house the 'alams, etc., but these are usually accommodated in the imāmbārā or 'äshür-khāna where there is one. The use of part of the mosque as a madrasa is commonplace, and many instances could be cited at the present day where there is no special provision for such a purpose; but there are instances of a special building forming an integral appendage of the mosque designated as a madrasa; e.g. Masjid Khayr al-Manāzil, near the Purānā Qil'a in Delhi, where the northern riwāq, of two storeys, forms the madrasa of the foundation.

The saln may be used also for graves, from the simplest tombstone to elaborate mausoleums; e.g. the Jāmi` Masjid of Fatehpur Sikri, where most of the northern side of the sahn is occupied by the tomb of Salīm Chishtī, the Zanāna Rauza, and the tomb of Nawwāb Islām Khān (not so designed originally, and possibly a jamáat-khāna for the saint's disciples).

A minarr is by no means an invariable appendage to the Indian mosque; apart from a few occasional early instances, only in the Gujarat Sultanate, and in Burhanpur in Khandesh, was a functional minār provided for the adhān before the Mughal period; after the 16th century, the minār becomes common, but not invariable.

The administration of the mosque may be under the $q \bar{a} d \bar{l}$, or, in the case of larger foundations, a committee headed by a mutawalli. Where a mosque stands on a high plinth there may be openings in it sufficiently large to be rented off as storerooms or to traders, in which case the revenues accrue to the mosque. 


\section{MINBARS*}

In the various building styles of mosques in India the typology of the minbar is very variable, from a crude construction of three simple stone steps to elaborately carved canopied structures of nine steps or more. Stone is always the preferred material, even in the brick-building region of Bengal; however, the absence of any structural minbar in many well-preserved old mosques may suggest that wooden minbars were also known, although no early examples have survived.

In none of the earliest mosques of the Delhi Sultanate is there an original minbar (that in the jamā'at-khāna at Nizāmuddīn, the oldest mosque still in worship, is a modern replacement; old photographs, however, show a simple minbar of three stone slabs). This pattern is maintained up to the Lōdī period, to judge by a very few extant examples in Delhi (e.g. mosque at Barā Gunbad; mosque at the $b \bar{a}$ ol known as Rājon kī bā'în); only in the special case of the $\bar{\imath} d g \bar{a} h$ attributed to Mullā Iqbāl Khan is there a more elaborate structure, a tall stone platform level with the top of the mihrāb arch whence the voice of the khațib might reach the great concourse gathered for the $i d$ assembly. Outside Delhi itself, the minbar of the Jāmi` Masjid of Irich, 815/1412, is a massive stone structure of seven steps, the last extended to a square platform supported on pillars.

Bengal shows excellent early examples of canopied minbars; the earliest, in carved basalt, in the Barī Masjid in Chota Pandua of the early 14th century, has nine steps leading to a domed upper chamber, with arched openings on three sides and what appears to be a mihrāb representation against the western wall of the prayer-chamber. This design was followed in the great Ādinna Masjid of Hazrat Pandua of 776/1374-5, where as Ravenshaw's photograph shows (J.H. Ravenshaw, Gaur: Its ruins and inscriptions, London 1878) the mihrāb-like decoration on the western wall is carved with the representation of a hanging lamp, and the outer surface carved with geometrical diaper patterns. Similar but plainer is the minbar of the nearby Quṭb Shāhī (Ravenshaw's "Golden”) mosque, 993/1585. Further instances of this type occur; but there are also many simple minbars of three simple stone slabs. One late aberrant minbar, in the mosque of Muhammad b. Tipū Sulțān, 1258/1842, consists of three polished stone steps occupying

\footnotetext{
* "Minbar, 3. In India," EI, VII. 79-80.
} 
half of the central mihrāb, space having been severely limited by the neo-Palladian design of this building.

In the few remaining buildings of the Jaunpur Sultanate, in Jaunpur itself, in the Jāmi' Masjid at Etawa, and in the Arhā'̄ Kangūra Masjid at Banaras (Varanasi), the minbar takes the form of a massive stone structure of nine steps up to a square stone platform, with no trace of there ever having been a canopy. The typological similarity to the Irich example mentioned above points to a geographical rather than a dynastic determinant of style.

The favourite style of minbar in the Gujarat Sultanate is again the massive stone nine-stepped structure, although as Ạ̣mad Shāh's mosque, the earliest in Ahmadabad (816/1414), shows, the upper platform was covered by a canopy; the canopy may be taken entirely from a Hindu temple mandapa, supported by pillaged pillars, although even when purpose-quarried stones are used they are often elaborately carved in accordance with the characteristic richness of the Gujarat style. The steps may further be enclosed by stone sides to form hand-rails, again with carved surfaces. In many mosques the canopies have been removed, probably when many fine stone buildings were plundered during the early years of Marāthā rule in the early 18th century. A feature found in many Gujarat mosques is the presence of a low square platform in front of the lowest step of the minbar; its original purpose is not clear, but it is not uncommon now to see it covered with mats and used to seat young students when the mosque is in use as a Qur'annic school.

In Malwa the canopied minbar is again the preferred style, as exemplified in that of the early mosque of Malik Mughith at Mandu, 835/1432, where the upper platform is surmounted by a square roof resting on pillars which appears to be temple spoil, with projecting eaves and a parapet surmounted by a row of shield-shaped merlons; to the west the wall takes the form of a mihrāb of black polished basalt, with the characteristic Malwa row of merlons in low relief. This is surpassed by the magnificient minbar of the Jāmi Masjid (completed 858/1454), perhaps the finest in the sub-continent: eleven steps lead to the upper platform, originally railed on north and south; the three open sides are of the same shape as the arches of the mihräbs, slightly ogival; the canopy itself has its eaves supported by sinous brackets, of the same shape as those in the Jāmi' Masjid of Dhar and of Hūshang's tomb in Mandu; above the row of merlons there is a marble dome of the characteristic Malwa shape, i.e. stilted below the haunch by being raised on a cylindrical drum. Here, as in the Gujarat mosques, there is again 
a square low platform at the foot of the minbar steps. At Chanderi the minbar of the Jāmi 'Masjid is typologically similar, but without the sinuous brackets and more solidly built (now whitewashed); that of the

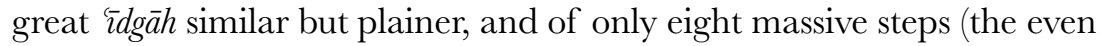
number is unusual).

In the Deccan, however, the minbar is usually of the plain pattern of three modest stone steps; so at the first Bahmanī mosque, the Jāmi Masjid of Gulbarga (769/1367), and others in Bidar. In the massive ìdgăh at Bijapur, certainly of Bahmanī date, the minbar has nine stone steps leading to an open platform; in the arched opening of the west wall behind it is a flight of smaller steps leading to the top of the wall. In the buildings at Bijapur (and Gogi) of the 'Ādil Shāhīs, the most ornate of the Deccan styles, the minbar remains of the simple pattern of three (occasionally five) stone steps, and the same is true of the Quṭb Shāhī mosques of Hyderabad.

Throughout the Mughal period, the minbar is of the stepped uncovered type. Sometimes, as at the Jāmi' Masjid in Fatehpur Sikri, the massive red sandstone steps have small pierced screens at their sides; in the time of Shāhjahān, when many modifications were also made to earlier buildings, the minbar is often a simple structure of three steps but built of polished, sometimes also inlaid, marble, and a few have a chair-like back slab which may carry a brief inscription. The Jāmic mosques of Delhi (Shāhjahānābād) and Agra each have a central platform, approached by steps, in the sahn, outside the prayer-chamber, which may fulfil the functional purpose of the minbar when there is a vast concourse of worshippers to be addressed, even though there is a minbar in its normal position within the prayer-chamber.

\section{MinARETS*}

The manāra in India, commonly referred to by the imāla form minār, may be either free-standing or an integral part of a mosque or other building. In the second category, it is convenient to distinguish the (actually or potentially) functional from the non-functional forms. With rare exceptions, in some regional styles no form of the mina $\bar{a}$ is used at all; Jaunpur; Malwa; the Delhi Sultanates and the pre-Mughal Panjab;

\footnotetext{
* "Manāra, 2. In India," EI, VI, 368-70.
} 
Sindh; Kashmir; the 'Imād Shāhī, Nizāam Shāhī and Barīd Shāhī Sultanates in the Deccan. (It might be objected that the non-functional forms do not properly qualify to be called minārs at all; but these forms, with others to be mentioned below, are certainly derived from minār prototypes, and there is no other recognized term by which they may conveniently be described. The term mina $\bar{r}$ is regularly applied to towers of many types and functions.)

The free-standing miña r first appears in India as an adjunct to the earliest mosque ("Quwwat al-Islām") in Delhi, standing outside the original mosque compound, commenced by Quṭb al-Dīn Aybak (whence, possibly, its sobriquet of "Quțb Mīnār") about 595/1199, and completed before $634 / 1236$ by Iletmish to a height of more than $68 \mathrm{~m}$. The taper of its profile is very pronounced, nearly $5^{\circ}$ from the vertical and it was divided into four stages by encircling balconies supported by muqarnas corbels; the three lower stages show different designs of vertical fluting, the flutes on the lowest stage being alternately rounded and angular, those in the second all rounded, those in the third all angular (the original fourth stage was rebuilt into two storeys in 770/1368 under Fìrūz Shāh Tughluq). The occurrence of the Qur'ān, LXII, 9-10, in an inscription on the second storey affords presumptive evidence for the use of the minarr as a midhana. The assertions that the fluted storeys develop the polygonal outline of the minarrs of Ghazni in Afghanistan, taken as the prototype of the Delhi minarr, now need modification in the light of later research: A. Hutt, in Three minarets in the Kirman region, in $\mathcal{F R A S}$ (1970), 172-80, shows that the section of the base of the minaret of the Masjid-i Jāmi' of Zarand has precisely the same disposition of alternate rounded and angular flutes; this is therefore a more exact exemplar for the Quṭb Mīnār than the minnārs at Ghazni, whose section is stellate, based on two interlaced squares. A minār in the Sīstān region, described by K. Fischer in Afghanistan, xxii/3-4 (1970), 91-107, of similar form, suggests a nearer prototype on the probable line of transmission to India. (There is thus now even less need to cite the form of the Doddabasappa temple in Dambal, Dharwar District, as a possible prototype of the Quṭb Mīnār plan, as has been advocated by some Hindu enthusiasts.) The characteristic taper of the Kirman examples, and of the minaret of Jam in Afghanistan, is also closer to that of the Quṭb Mīnār than are the Ghazni examples. These details are emphasized here because of their persistence in certain aspects of mosque architecture, described below. 
Other free-standing minārs stand or stood at Koyl (Aligarh) (inscr. 652/1254): erected by Balban as governor to commemorate victories of the sulțān Nāṣir al-Dīn Maḥmūd; tapering with square base and external galleries supported by cornices, with internal spiral stair, but demolished in 1862 without adequate record; Bayana: cylindrical with slight entasis but unfinished, in city near Ukhā Mandir and Ukhā Masjid, 15th century, and tall min̄ar in hilltop fort, tapered with corbelled balcony, inscr. 871/1466 (?), possibly with a double staircase; Daulatabad: Chānd Mīnār in inner city, c. 849/1445, three encircling galleries supported by elaborate brackets, similar profile to minārs of madrasa in Bidar; Bidar town: Chaubāra, low cylindrical tower at crossing of main thoroughfares, early 15th century; Chota Pandua in Bengal: massive min̄ar $50 \mathrm{~m}$. from Barī Masjid, early 14th century, five diminishing tiers resembling half-drawn-out telescope, lowest three fluted; Gaur: Firūz Mīnār, c. 895/1490, no taper, polygonal section. Both Hiran Mīnār at Fatehpur Sikri and "Nīm sarā'ī Mīnār" at Old Malda, Bengal, are tapered with stone projections resembling elephant tusks (on which to display heads of rebels?), Mughal, 16th century; Delhi: "Chōr Mīnār", early 15th century, many holes for same purpose; Shaykhupura, Panjab (Pakistan), Hiran Mīnār, 30 m., tapering, 1044/1635, popularly sometimes supposed to commemorate Jahāngīr's favourite elephant, but often attributed to Dārā Shukōh. Finally, the Kōs Mīnārs of the early Mughal period, solid towers of similar profile to the Quṭb Mīnār, but only 6-8 m. high, were set at intervals of $1 k \bar{s}$ along the major thoroughfares. Many purposes are involved in the above: mi'dhana; observation post to command dead ground; possibly, following Hindu examples, "victory tower"; other commemoration; platform for shooting or observating game; execution displays; distance markers. The purposes are frequently combined.

The second category of minarrs, those attached to a mosque or other building, however, are provided primarily as mi'dhanas, although since they are almost always multiplied symmetrically, they obviously have also an important aesthetic function (the single mina $\bar{r}$ in the south-east corner of the courtyard of the Bahmanī period Ek mīnār kī Masjid at Raichur is a striking exception). Only in Gujarat under the Ahmad Shāhī Sultanate, and in Burhanpur in Khandesh, are paired functional minārs used regularly before the Mughal period; here they are cylindrical, their internal staircases opening on to one or more encircling balconies supported on heavy corbels as well as to the mosque 
roof, and are capped by conical roofs with no suggestion of an open turret. The earliest Ahmmad Shāhī examples flank the central arch of the tiwe ann, although later they may be placed at the north and south ends of the façade. The latest mosques of the Ahmad Shāhī period, e.g. Rānī Sabarì's mosque and the İsānpur one, have solid pseudo- minārs at the ends of the façade.

This sudden reintroduction of the mi'dhana-mina $\bar{r}$, with an immediate secondary aesthetic function, is not fully explained. Gujarat mosques in Delhi Sultanate times, such as Hilāl Khān's one at Dholka and the Jāmi` Masjid at Cambay, have only solid conical or cylindrical pillars over the parapet flanking the central bay of the $\bar{k} w \bar{a} n$; but earlier Delhi Sultanate examples outside Gujarat may show the connection with the Quṭb Mīnār; e.g. the Arhāî̀ din kā Jhōmprā mosque at Ajmer carries two cylindrical turrets, solid and some $2 \mathrm{~m}$. tall, over the maqșüra arch, with vertical flutes alternately circular and angular exactly as on the lowest storey of the Quṭb Minnār (similar fluting occurs on the external corner buttresses of the mosque courtyard). In Delhi itself, the Quṭb Mīnār profile is perpetuated in the solid buttresses which flank mosque gateways, the central bay of the tiwean façade, the external mihrāb-projection, and external corners of courtyards, in the Tughluq and Lōdī periods; these show at least one band of Quṭb Mīnār-like fluting, and their profile is carried up above parapet level to end in a guldasta; especially when flanking the central propylon-like arch of the liw $w$ an façade, these suggest paired mi'dhana towers, and may thus have a psychological purpose. This would seem to be the explanation for many of the examples which follow. In the Bahmani Sultanate, the minār is not used regularly with mosques; that at Raichur mentioned above is an exception, and the Chānd Mīnār at Daulatabad is doubtless sited with the older Jāmi` Masjid in mind, although physically separated by some $100 \mathrm{~m}$. - doubtless also to enable a view of broken ground to the east. The profile of both resembles that of the remaining one minarr of two at the ends of the entrance façade of the madrasa of Mahmūd Gāwān at Bidar, inscr. 877/1472, although the balconies of the latter are carried out from the main shaft in a curvilinear form rather than being supported on brackets in the usual Indian manner. All are crowned with a dome-shaped cap, with no open room at the top. The old brick minnars attached to the courtyard of the much later Makkā Masjid at Bijapur, also of Bahmanī date, have lost their upper parts; their balconies seem to have been supported on wooden brackets. Other 
Bahmani min̄arrs, all of similar profile, are the pairs flanking the gateways of the dargāh of Shaykh Sirāj al-Dīn Junaydī and the so-called House of Gīsū Dārāz, both in Gulbarga, and those flanking both the outer and inner gateways of the dargāh at Aland; but these are crowned with foliated domes of three-quarter sphere shape, as in the 'Ādil Shāhī and Quṭb Shāhī styles, and those of the outer gateway have moreover an encircling band of open arches in the Quṭb Shāhī manner.

Of possible relevance to the designs in North India referred to above are the guldastas which stand at the corners of the parapets of Bahmani tombs, starting with the very earliest at Gulbarga: these are fluted, although fluting does not extend to the minnars. The minār proper is not used at all in the Bahman̄is' successor states. The skylines of mosques and tombs of the 'Âdil Shāhīs in Bijapur and elsewhere are so liberally provided with vertical pillars as to resemble a burgeoning asparagus bed, but these are at best pseudo-minārs which may psychologically suggest the midhana-minār but whose real function is merely artistic. Turrets, chhatris and guldastas are also freely used, but the relation between these forms cannot be pursued here. The minār-like structures of the Quṭb Shāhīs of Hyderabad and Golkonda, similarly, are usually solid shafts, cylindrical, with characteristic encircling arcaded galleries, although in a late off-shoot of the Quṭb Shāhī style in the Jāmi` Masjid of Srirangapattana an internal staircase is provided. That the bases of the pseudo-minārs of the Tōli Masjid (1082/1671) outside Hyderabad city stand in pot-shaped bases should not be taken as representing any connexion with ancient Indian pillars.

Under the Mughals, the functional minār returns to North India; this is possibly inspired by Gujarat examples, since other typically Gujarati features are introduced into Mughal architecture after the conquest of the region in 980/1573. The first example is that of the four minarrs at the corners of the gateway of Akbar's tomb at Sikandra, completed in the early years of the 17th century: tapering, white marble (the lowest stage fluted), two intermediate balconies supported on corbel brackets, topped by an open chhatri with slender columns. With some variation in the patterns of the intermediate balconies, and of the material, section and decoration of the shaft, this type is the model for the major later minārs: at Jahāngīr's tomb in Lahore; the Jāmi 'Masjid (Shāhjahānābād) Delhi; the Tāj Mahall at Agra (but not the Jāmi` Masjid); the mosque of Wazīr Khān at Lahore; the Bādshāhī mosque of Lahore, which has also short miñăr-like corner turrets; the tomb of Rābi a Daurānī ("Bībì kā 
Maqbara") at Aurangabad; Aurangzīb's mosques in Banaras (Varanasi), Mathura, etc.; short corner staircased minārs also at the tomb of I'timād ad-Daula at Agra, little more than turrets, seem to be the model for engaged corner turrets at e.g. the tomb of Șafdar Jang at Delhi, and Mughal mosques in Bengal e.g. Dhaka, Murshidabad, etc. Since there is no necessity for the $\bar{a} d h \bar{a} n$ at tombs, many of these Mughal minnarrs are thus also principally decorative.

\section{IDGAHS*}

Also known as namāzgāh, "place of prayer", the $\bar{\imath} d g \bar{a} h$ is general the open structure built usually to the west of a town, consisting solely of what in a mosque would be the western wall, with mihräb(s) and minbar and, essentially, within a spacious enclosure which should be capable of accommodating the entire adult male Muslim population; the wallstructure may stand at the western end of a large paved area (sahn), but there is usually no hauz for ablutions. The structure is used only for the celebration of the two $i d$ festivals ( $i d$ al-adh $\bar{a}$ and $i d$ al-fitr), and no special sanctity attaches to it; this may account for the destruction of many old $i d g a \bar{h} s$.

The namāzgāh/ídgăh in Muslim settlements in India is often a substantial building of some artistic merit, e.g. the Bahmanī $i d g \bar{a} h$ at Bijapur; the splendid $\hat{\imath} d g \bar{a} h$ at Chanderi in Malwa with its mihrāb wall, canopied minbar in typical Malwa style, and tapering end buttresses with domes; the early Tughluq Kharērā 'ìdgāh, near Sīrī in Delhi (from the minbar of which Tîmūr possibly held his open-air court; an earlier $\bar{\imath} d g \bar{a} h$ to the west of Qil'a Rāy Pithorā has also been suggested, further from Tìmūr's battlefield. The Malfüzāt-i Tìmūrn, tr. in Elliot and Dowson, iii, 443, does not state the location precisely); the very early (possibly of the time of Iletmish, with Khaljī and Tughluq additions) $\bar{\imath} d g \bar{a} h$ of Badaun, with octagonal end buttresses, domed, the central mihrāb under a halfdome faced with a tall arched opening almost double the height of the main wall; there is a tall canopied minbar and, most unusually, an arched opening beside the minbar leading to the rear of the structure (K.V. Soundara Rajan, Islam builds in India, Delhi 1983, 68-9 with plan and elevation, and pl. 29); the vast 'ìdgăh at Delhi (presumably of Fìrūzābād,

* "Namāzgāh,” EI, VII, 947. 
situated north-west of the Qadam Shariff), probably of Tughluq times but with later additions, stands within a well-fortified enclosure. At Gulbarga, the growth of the town is expressed by the presence of three idga $\bar{h}$ s to the west of the town. There are many more fine $i d g a \bar{h} \mathrm{~s}$ all over the country, but unfortunately few have been published.

The word namäzgāh is also used for those small areas seen in sparselypopulated regions in Baluchistan and the North-West Frontier region of Pakistan, sometimes simply a square or rectangle demarcated by whitewashed stones, with a larger stone at the western end to designate the qibla, and where there is no pretence of an enclosure.

\section{Tombs*}

The word maqbara is used in India for both graveyard and mausoleum, although qabristān is also heard for the former; qabr may, besides the grave itself, signify a monumental tomb, especially of the simpler variety; dargāh is used especially for the tomb or shrine of a $p \bar{r}$, where there may be also such associated buildings as a mosque, mihmān-khāna, etc.; in Kashmir a pir's tomb is usually called ziyarat, and the related mazār may also be used, especially for the smaller wayside shrine; rauza is commonly used for a monumental tomb within an enclosure, not necessarily of a pir.

In India the solitary grave is rare; the individual may select an appropriate site in his lifetime, usually on his own ground (but sometimes by a roadside, since it is believed that the dead like to be within sound of human activity). But because this action then precludes the use of the ground for other purposes, the individual grave becomes a focus for other sepulchres. In this way many family graveyards especially have come into being - "family" in the case of a pir being held to include murids. There is a tendency in some regions for graveyards of the Muslim community to be situated to the south of habitations, possibly an extension of the Hindu association of the south as the "quarter of Yama", the god of death: in the Lōdi period the entire region of Delhi south of Fīnūzābād and Purānā Qil'a down to the Quṭb complex was used mostly as a vast necropolis. Khuldabad, near Daulatabad in the Deccan, was originally called simply Rauza and was a necropolis village.

* "Makbara, 5. India," EI, VI, 125-8. 
Community graveyards may be enclosed by a low boundary wall, but protection is generally careless and graves and walls may fall into early ruin. Some enclosures are known to be family graveyards, where the standard of upkeep is higher; there may be an imposing entrance to the east and a tall and substantial wall to the west, with arched openings or depressions which serve to indicate the qibla; some of the Delhi examples (Yamamoto et al., Architectural remains of the Delhi sultanate period, 3 vols., Tokyo, 1967, list and illustrate some 72 graveyards) stand on high arcaded plinths and may have such features as substantial corner towers and the position of the central milhra $b$ indicated on the exterior wall, precisely as in mosques. In the Qadam Sharif at Delhi the enclosure wall is fortified, as a measure of protection for the special relic; but the fortified rocky outcrop on which stands the tomb of Tughluq Shāh is primarily an extreme outpost of the fortifications of Tughluqābād (plan in Yamamoto op. cit., ii, 257). In Ahmadabad the tombs of the queens of the Aḥmad Shāhī dynasty are enclosed in a large screened chamber (Rānī kā hujura) which forms part of a royal precinct; a fine enclosed graveyard known as "Niẓām al-Dīn's" in Chanderi contains tombs and many individual mihrābs from the early 15th century with a rich design repertory. Some graveyards may contain one or more substantial mausoleums in addition to simple graves. An indication of the qibla may be provided, even in unenclosed graveyards, by one or more "qibla walls", with an odd number of arched necesses; individual mausoleums may also be provided with such a separate structure on the qibla side, or the enclosure wall may be modified in such a way as to incorporate one: e.g. the tomb of Sikandar Lōdī in Delhi has three arches and a raised platform in the west enclosure wall which presumably formed a qanāt mosque. A mausoleum very often has openings on three sides with the west wall solid to incorporate an internal mihra $b$ (the tombs of the Barīd Shāhīs, however, are regularly open on all four sides). The larger mausoleums may be provided with a full-scale mosque (without minbar), either replacing or in addition to an internal mihrāb; Bijapur provides many excellent examples, of which the Ibrāhīm Rauza is the finest example with tomb and mosque of similar proportions and sumptuous decoration standing on a common platform in an elaborate enclosure; the Tāj Mahall has not only a superb mosque on the qibla side but an identical building on the east essentially for the symmetry of the plan but incidentally to serve as a mihmān-khāna. (The converse arrangement, wherein a single tomb is subsidiary to a mosque, is common, especially when both have the same founder.) Some major mausolea, however, 
are without any indication of the qibla at all: e.g. Humāyūn's tomb at Delhi (plan in Yamamoto op. cit., ii, 265) has neither internal mihrāb nor external mosque or other structure (the building on the west, where a mosque might be expected, is in fact the main gateway); although the enclosure wall on the south-east has a range of exterior arches which formed the qibla wall of the earlier "Nīla Gunbad". At some graveyards there is a special mortuary provided for the ghassāls to work in: outstanding examples at the graveyard of Afzal Khān's wives at Bijapur, and the tombs of the Quṭb Shāhī kings at Golkonda. Some form of well is of course a common adjunct; a $b \bar{a}$ o $l \bar{\imath}$ is commonly found included in a Chishtī dargāh complex, and occasionally elsewhere (e.g. within the fortified enclosure of the tomb of the "Sayyid" sultān Mubārak Shāh at Kōtlā Mubārakpur, Delhi).

There has been no study of the typology of gravestones (i.e. the stone or brick structures above ground level, the $t a^{\prime} w \bar{\imath} d h$ ) in India as a whole, although many types with regional variation can be recognized. Ja far Shariff, referring primarily to the Deccan, says that on a man's tomb, above the (commonly) three diminishing rectangular slabs, a top member is placed "resembling the hump on a camel's back, or the back of a fish", and adds that in North India tombs of men are distinguished by a small stone pencase (qalamdān) raised on the flat upper surface; but in fact both types can be seen side by side in Delhi graveyards. The tombs of women are generally flat above the diminishing rectangular slabs, and more frequently in North India than in the Deccan may display a flat $t a k h t \bar{i}$, in form like a child's slate, where those of men have the qalamdān (the explanation commonly given is that only males are literate and so can carry a pencase, whereas women have to have everything written for them!); in South India in particular a woman's tomb may have instead a basin-like hollow on the upper surface. The woman's tomb, given the same date and provenance, is lower than the man's. In the case of the larger mausoleums, this applies to the cenotaph tairidh as much as to the tawidh of the actual grave. There may be, in both men's and women's tombs, a mere stepped surround with the internal rectangular space filled with earth (e.g. grave of Aurangzīb at Khuldabad) or grass (e.g. grave of Jahānāra Bēgum, daughter of Shāhjahān, within the dargāh of Nizạam al-Dīn Auliyā' at Delhi, where however the surround and the enclosure are of white marble and there is an inscribed marble headstone; plan in Yamamoto op. cit., ii, 263). This is much approved by the pious, but leads to quick decay of the structure if the grave is not attended. In parts of Western India in particular a cylindrical 
boss may be found at the head of the tomb of a man, sometimes in addition to an inscribed headstone. In Gujarat the "casket" style of tomb is favoured, at least for the more exalted personages, in which a rectangular chamber with vertical sides, about a cubit high, rises from the base and is capped by the shallow diminishing rectangular slabs, finished flat in the case of women, arched or triangular in cross-section for men; they may have in addition cylindrical corner stones with vertical ribbing and two or three cross-mouldings. Dr Zajadacz-Hastenrath (see below), describing similar forms in the Chaukhandi tombs in Pakistan, sees here a representation of the $\operatorname{cha} r p \bar{a} \bar{\imath}$ (string bed) with rope lashings which would have been used as the bier. A chiräghdān, to carry lamps or on which fragrant substances may be burnt, may be placed at the head of or alongside any tomb; the actual grave may, in the case of the illustrious, be covered with a pall kept in place by ornamental weights $(m \bar{r}-i$ farsh). The tomb of a pir may be marked also by a white (or green in the case of a sayyid) triangular flag carried on a tall bamboo, especially in country districts.

It is only in the case of the remarkable Chaukhandi tombs that anything like a systematic study has been made (Salome ZajadaczHastenrath, Chaukhandigräber: Studien zur Grabkunst in Sind und Baluchistan, Wiesbaden 1978). In the most characteristic (but not the only) style one, two or three diminishing rectangular hollow "caskets" are superimposed, and are capped by a final slab set vertically on edge. The cylindrical boss at the head may be added in the case of males. They are richly carved, either with geometrical patterns (the author gives ten plates of "Steinmetzmuster" alone), flowers, whorls, mihrāb-like blind arches, swords, bows, and even the figure of a horseman carrying a spear, sometimes led by an attendant. Similar carvings (or paintings on wood) are reported in Crooke's ed. of Ja far Sharîf from Afghanistan, Kurdistan, and the Orakzay Pathāns; this ethnological aspect stands in need of further investigation.

A curious class of tomb, sparsely but widely distributed, is that of the "nine-yard saints", nau gaz pir, usually ascribed to warrior saints of the earliest days of Islam in India. Many of these have the reputation of miraculously extending their length over the ages. (Miracles are reported at other tombs: lumps of silver in the pavement of the dargāh of Muntajib al-Dīn "Zar Bakhsh" at Khuldabad are said to be the remains of silver trees which grew after the saint's death, which were broken off for the upkeep of the shrine; hairs from the Prophet's beard at the same place are said to increase in number yearly.) Many tombs 
have the reputation of curing various ailments through the thaumaturgic power of a pir persisting; e.g. women still tie ribbons on the lattice screens on the tomb of Salīm Chishtī at Fatehpur Sikri as a cure for barrenness. (The virtue is not confined to Muslims: Hindu women often make oblations at the tomb of the Qādirī brothers at Bijapur.)

Tombs may bear inscriptions (and inscribed tombs, from reverence for the written word, stand a better chance of being looked after in later years): on the tawidh itself sometimes simply a name and date of decease, more often the kalima or Qur'annic verses such as the Ayat al-kursī, II.256, the conclusion of II.157, or the very end of Sūra II; there may be, especially with the tombs of men in Gujarat, a sizeable headstone with a more elaborate epitaph; but so many tombstones are devoid of any information on the deceased that many obviously major mausolea cannot be now identified. The cenotaph of Akbar, of white marble, is inscribed on the sides with the 99 Names of God, and on the ends the Dīn-i Ilāhī formulae "Allāh Akbar" and "Galla Falālah". On the ta'wìdh of Jahāngīr the Names are inscribed in pietra dura. Often in the case of mausolea an inscription is placed within the entrance or on a wall, and copious Qur'ānic texts may be inscribed on the façade, e.g. at the Tāj Mahall.

The graves above belong to the mainstream tradition of Islamic art, which may be described as the "Greater Tradition"; graves of a "Lesser Tradition", belonging to a stream of folk-art, have been observed in Gilgit, Punial, the Swat valley and the Yusufzay country of Northern Pakistan, and may have a more extensive area. These, which do not always distinguish between the graves of males and females, have a crude indication of the north-south axis marked by slabs of stone, or by wooden planks which may be carved into various shapes, or by turned wooden posts; they may also be surrounded by an open wooden framework which, it is suggested, represents the bier inverted over the sepulture, and may be analogous to the chārpa $\bar{a} \bar{\imath}$ representations in the Chaukhandi tombs. A fuller description, with map and drawings, in J. Burton-Page, Muslim graves of the 'lesser tradition': Gilgit, Punial, Swat, Tusufzai, in $\mathcal{F R A S ~ ( 1 9 8 6 ) . ~}$

The typology of the mausoleum is too complicated for any but the most summary treatment here. The simplest type, in that it provides a covered place over the $t a{ }^{i} w \bar{r} h$, is the chhatri, a single dome supported on pillars; those covering a square or octagonal area are the commonest, although the hexagonal plan is known. From the use of the umbrella in both Buddhist and Hindu funerary practices, there is possibly here 
a persistence of an eschatological idea (but the Hindu use of the chhatri to mark the site of a cremation, so common with the Rājpūt rulers at e.g. Udaipur and Jaipur, is a borrowing back from Muslim forms). Even with this simplest type there is the possibility of the common principle that a funeral building (or its site; $c f$. the tomb of Tughluq Shāh mentioned above) might be intended for a different purpose during its owner's lifetime. An elaboration is to support a square roof on twelve pillars, thereby furnishing three openings on each side as well as making possible a larger area (this type of building, bāradañ, is also of wide secular use for pleasaunces). Filling in the openings with stone screens $(j \bar{a} \bar{\imath})$, leaving an entrance on each side, is frequently practised, although as noticed above the western side is often completely closed to provide an indication of qibla; Tomb 2 at Thalner is a bäradari whose sides have been filled in with purpose-cut masonry. An extension of this type is characteristic of Gujarat, whereby both an inner chamber and a surrounding verandah are provided with screened walls; after the Mughal conquest of Gujarat tombs of this type are found in North India, e.g. those of Muhammad Ghaus at Gwalior, Salīm Chishtī at Fatehpur Sikri. When a tomb is given greater prominence by being raised on a plinth, the sepulchral chamber may be placed at earth level in a tahkhanna, with a cenotaph $t a$ wendh immediately above it on an upper floor; but where this applies to the principal inhumation at a large mausoleum, it is not practised for later and subsidiary burials, and is not held to be required for burials within a raised mosque șahn. The preponderant form of the masonry mausoleum is a square chamber surmounted by a dome; an idiosyncratic type occurs in the royal Bahmanī tombs (Haft Gunbad) at Gulbarga, where two square domed chambers are conjoined on a single plinth (the sultān in one chamber, his immediate family adjoining); but the octagonal form is also known from the 14th century (popular for royal tombs of the "Sayyid" and Lōdī dynasties, tombs of pirrs at Multan and Ucch, nobles of the Sūrī dynasty, especially Shēr Shāh Sūrī, and not infrequently in Mughal times); in the earliest monumental tomb, that of Nāṣir al-Dīn Maḥmūd ("Sulțān Ghārī") at Delhi, the plinth of the structure accommodates a vaulted octagonal sepulchral chamber. In two of the Sūri tombs at Sasaram the mausoleum stands in the middle of an artificial lake, approached by a gateway and causeway; the idea recurs in the Mughal period with fine but anonymous examples at I'timādpur, near Agra, and Narnaul, where the idea of a pleasaunce for use in the lifetime of the subject seems patent. Mughal mausolea introduce new plans: the oblong, the square or oblong with chamfered 
corners to produce a "Baghdādī octagon" (e.g. the Tāj Maḥall), a square chamber with engaged corner rooms (e.g. Humāyūn's tomb, tomb of 'Abd al-Rahīm Khān-i Khānān) or engaged corner turrets (e.g. tomb of Șafdar Jang). They may also incorporate independent symmetrically disposed minarets, and may stand within a formal garden.

\section{WAter Monuments*}

In a land so dependent generally on the summer monsoon, where there are few permanent sources of water away from the great rivers and their surrounding terrain where the water-table is high, human settlement depends on artificial means of conserving water from one rainy season to the next. Many of these utilitarian works, however, frequently take elaborate architectural form and are decorated beyond the call of functionalism.

Many water monuments in India were constructed before the coming of the Muslims, who continued not only their function and form (except for the elimination of figural ornament and the introduction of the arch) but also their maintenance through civil or waqf funds. The simplest examples are large open reservoirs in and around towns (commonly called "tanks" in India; see Yule and Burnell, Hobson-fobson, for etymologies; also $t \bar{a} l, t \bar{a} l \bar{a} \bar{o}$, and in the case of Muslim constructions also hauz), of all shapes but commonly rectangular, sometimes with masonry surrounds and steps leading well below the average waterlevel; as the water was used or dried up more steps would be exposed, the shelves being convenient for personal ablutions or for washing clothes; pavilions (kūshk, chhatrī) may be added mainly for ornament. Similar masonry surrounds $(g h \bar{a} t)$ may be provided on river banks or on artificial lakes caused by damming a valley (e.g. the Anāsāgar at Ajmer, the Picholā at Udaipur). Since open expanses of water cause a perceptible change in the microclimate, buildings might be sited to take advantage of the cooling effects of evaporation (e.g. Fīrūz Shāh's madrasa and other structures on two sides of the Hauz Khāṣs at Delhi, Mahmmūd Shāh's palace, the tombs and the mosque at Sarkhej on the outskirts of Ahmadabad; and many pleasaunces may be sited in the

\footnotetext{
* "Mā', 12. Ornamental uses of water in Muslim India," EI, V, 888-9.
} 
middle of an artificial tank (e.g. Jahāngīr's Hiran Mīnār complex at Shaykhupura in Pakistan, the tombs of Shēr Shāh and Salīm Shāh at Sasaram, Mughal kiosks at Narnaul, the Zafar Mahall in the Hayāt Bakhsh garden in Delhi; the tombs would have been used as pleasant retreats during the owners' lifetime.

Tanks and artificial lakes fed from constant sources naturally need provision to be made for the escape of surplus water; overflow tunnels and sluices may occasionally be sumptuously decorated, as at Sarkhej, but the simpler structures in the local quartzite at Delhi have a monumental beauty of their own, e.g. that on a water-channel off the Najafgarh canal at Wazīrābād, with an included silt (and fish?) trap; those on the bund connecting Tughluqābād with 'Ādilābād, whereby the low-lying fields to the south of Tughluqābād could be flooded to a depth of some $2 \mathrm{~m}$. to create an artificial lake for the defence of the citadel and leaving Ghiyāth al-Dīn's tomb as an isolated outpost; and, more complex, a two-storeyed sluiced dam, called Sāt Pulah, built into the south wall of Muhammad b. Tughluq's Jahānpanāh to regulate the storage of water within the city (analyses, photographs and measured drawing of all these in Yamamoto et al., Architectural remains of the Delhi sultanate period, 3 vols. Tokyo 1967, iii).

The simple well does not much lend itself to ornamentation, but may form part of a complex, such as Jahāngīr caused to be constructed at day's-march intervals along the road to Kashmir, of sarā $\imath+$ mosque + well, water from the latter being taken up by charas to irrigate a small flower-garden. The step-well $\left(b \bar{a}^{\prime} o l \bar{\imath}\right)$, however, is most frequently decorative as well as functional, providing chambers at various levels close to the water's edge to provide cool retreats in summer; e.g. in Delhi the Gandhak kī bā’olī, c. 630/1233; the circular $b \bar{a}^{3} o l \overline{~ i n ~ F i ̀ r u ̄ z ~ S h a ̄ h ~}$ Kōtlā, c. 753/1352; and the superb Rājōn kī bāìn, inscr. 912/1506 (all analysed in Yamamoto, op. cit., iii, with photographs and measured drawings). Analogous structures in Gujarat, called vāo, have the entire well covered at surface level.

Water was a necessary adjunct to palaces and gardens, and might be provided, when either of these two was beside or close to a river or lake, by a Persian wheel (rahat); a further Persian wheel, or series of wheels, housed in a tower, might be used to raise the water to a greater height when it was necessary to provide a sufficient head of water to operate fountains. The water was led through palace courtyards and gardens by stone channels, often with intermediate cisterns which 
could be highly ornamental, as that in the Lā'l Bāgh at Bidar (plan in Yazdani, Bidar, 53); in Bijapur, where all the centre of the city was supplied by underground channels from the Chānd and Tāj Bā’orīs, a special water-pavilion, jal-mandiri, in the elaborate later 'Ādil Shāhī style, discharged water from jets into a large stone surrounding tank to make a visual focal point in the city scheme. Under the Mughals, however, the garden was developed more than ever before as a new art form. The ideal garden shape was a fourfold plan, chahär-băgh (the name châr-băgh persists in many Indian towns as the name of a locality even where no traces of gardens remain), as in e.g. the garden surrounding Humāyūn's tomb in Delhi, where the divisions are marked by water-channels with cisterns at or seats over the intersections; the pattern was followed and augmented in later tomb complexes: notably Akbar's tomb at Sikandra, the tomb of I'timād ad-Daula and the Tāj Mahall at Agra, the tomb of Aurangzīb's queen ("Bībī kā maqbara") at Aurangabad, and that of Safdar Jang at Delhi, where the principal channels are often expanded into stone - often marble - basins 3 or $4 \mathrm{~m}$. wide with a central rank of fountains, terminating on the cross axes in ba aradaris. Similar gardens exist apart from tombs and palaces, e.g. Rām Bāgh, Zahrā Bāgh, Wazīr Khān kā Bāgh, Mihtar Khān kā Bāgh, Achānak Bāgh, all at Agra (ASI, iv [1871-2], 104 ff); in his suggestive (but sometimes naïve) Early garden-palaces of the great Mughals, in OA NS, iv/2 (1958), 3-10, R.A. Jairazbhoy proposes the latter as the site of Bābur's original chahār-bāgh in India.

Mughal gardens reached their peak of perfection in Kashmir, where at Srinagar, Akbār's Nasīm Bāgh, Āṣaf Khān's Nishāṭ Bāgh and Jahāngīr's Shālīmār took advantage of the copious natural water supply; 'Alī Mardān Khān's canal from the Ravi river made possible Shāhjahān's Shālīmār outside Lahore. These make use of ābshār, waterchute, an oblique bed of flat or scalloped marble, and jharnā, cascade, with water flowing in a sheet over a straight edge to fall over a vertical bank of small niches, each intended to hold a small lamp with a shade of coloured glass. A curious late Mughal water monument is the Pān Chhakkī, water-mill, in the shrine of Bābā Shāh Muẓaffar Chishtī, a spiritual preceptor of Aurangzīb, outside the city walls of Aurangabad: water brought from a distance falls through some $7 \mathrm{~m}$. to operate a small mill, and the water then flows through two large tanks. Mughal water monuments and gardens were much imitated by Hindu rulers in Rajasthan. The Sahēliyon kā Bāgh in Udaipur offers a number of 
fountains of different designs fed by water under high pressure from one of the city lakes, in a more extravagant taste than any Mughal conception. The small palace at Dig is more refined in its elegant tanks and channels, and water is led in copper pipes over the openings of the buildings in order to flow over screens of khas grass, to cool and perfume the air passing through.

The devices of water decoration embodied in the gardens are found also in Mughal forts and palaces. These sometimes involved bringing water from considerable distances (e.g. 'Alī Mardān Khān's canal which supplied the Red Fort at Shāhjahānābād, Delhi, tapped the Yamuna over $100 \mathrm{~km}$. away; see W.E. Baker, Memoranda on the western Fumna canal..., London 1849; some of the aqueducts involved are themselves works of art). In the Red Fort of Shāhjahānābād, the water is further raised in the Shāh Burj, from an open pavilion in front of which, with ābshār and jarna $\bar{a}$, water flows through a marble channel, the Nahr-i Bihisht, which not only supplies the Hayāt Bakhsh and other gardens but also flows through all the palaces on the east wall at a depth of some 15 $\mathrm{cm}$., whose supreme achievement is a shallow basin $3 \mathrm{~m}$. square in the Rang Mahall, carved into the shape of an open lotus flower; this was of one piece of the finest Makrana marble and inlaid with semi-precious stones. When the water flows over it the petals of the flower appear to move and ripple. The Hayāt Bakhsh garden has additionally two marble pavilions with jarnās, called Sāwan and Bhādon after the first two months of the rainy season in the Hindu calendar, with a fine central tank with scalloped red sandstone borders which again are intended to be barely covered with water to produce a ripple effect. Comparable works in the Agra fort, of the time of Shāhjahān's additions, include a very deep ābshār outside the Mahall-i Khāṣs and an elegant fountain in the Muthamman Burj.

Bridges may be included in ornamental works. One near the tomb of Sikandar Lōdī in Delhi, but of Mughal date, is rather a pleasant spot for strollers to catch the water-cooled breeze than a work of strict necessity for transport, although the Mughals brought an elegance to bridges of greater functional necessity. Outstanding is the bridge at Jaunpur, whose two parts are provided with kiosks with carved marble screens to take advantage of the breezes along the river. 


\section{SteP-Wells*}

The Urdū and Hindī word for step-well is $b \bar{a}$ olt two main types, the northern and the western. The Northern Indian variety is the simpler, consisting essentially of one broad flight of stone steps running from ground level to below the waterline, the whole width of the site; subsidiary flights may run opposite and at right angles to these below water-level, thus constricting the cistern itself into successively smaller squares, and these may be supplemented by cross-flights reducing the final cross-sectional area of the cistern to an octagon. The sides other than that composed of the main flight are vertical, of stone or, less commonly, of brick. The whole site is usually rectangular - the $b \bar{a}$ ot $\bar{\imath}$ outside the Buland Darwazā at Fatehpur Sikri, associated with Shaykh Salim Chishtī is a notable exception, the nature of the terrain having made an irregular polygon the only shape possible - with apparently no consistency in orientation: e.g., the $b \bar{a}$ ot $\bar{\imath}$ at the darga $\bar{h}$ of Nizām al-Dīn Auliyā', near Humāyūn's tomb, Delhi, runs north and south in alignment with the shrine, while that at the dargāh of Khwāja Quṭb al-Dīn Bakhtiyār Kākī at Mehraulī in south Delhi runs east-west and is not aligned with any major structure. Such $b \bar{a}$ olìs are functional structures, from which water may be drawn and in which ablutions may be carried out, and into which men dive, often from a height of $20 \mathrm{~m}$., to recover alms cast in by pilgrims. They are usually unadorned, but often of a monumental beauty on account of their size: e.g., that of Nizām al-Dīn is $37.4 \mathrm{~m}$. long by $16.2 \mathrm{~m}$. broad, and some $20 \mathrm{~m}$. deep from ground level to average water-level.

$B \bar{a}{ }^{\prime} o l \bar{\imath}$ s are found at the principal shrines associated with Chishtī pirrs; besides the examples already noted, a fine rock-cut $b \bar{a}$ o $l \bar{\imath}$ is at the dargāh of Shaykh Mu'īn Dīn Chishtī at Ajmer. The reason for this particular association is not clear. Other $b \bar{a}$ os $\bar{\imath} \mathrm{s}$, smaller but of similar type, are not uncommon at other Islamic sites in North India, concerning which there is no reason to suppose any Chishtī connection. Pre-Islamic examples are not recorded here.

The Western Indian variety, generally known by the Gujarātī word $v \bar{a} v$, is of high artistic and architectural merit as well as functional; it is more elaborate than its northern counterpart and consists of two parts: a vertical circular or octagonal shaft, from which water may be drawn

\footnotetext{
* "Bā'olī," EI, I, 1024.
} 
up as from an ordinary well, and a series of galleries connected by flights of steps, with pillared landings on the lower galleries supporting the galleries above; passages from each landing run to the shaft, where there are frequently chambers which form a cool retreat in the hot season. Such structures are known in Gujarat from pre-Muslim times: Mātā Bhavānī’s vāv in Ahmadabad, the best preserved Hindu prototype, is probably 11 th century (Burgess, $A S W I$, viii, 1-3); Bāī Harīr's vāv in Ahmadabad, which bears a Sanskrit inscription equivalent to A.D. 1499 and an Arabic one of 8 Jumādā I 906/30 Nov. 1500, has ornament very similar to that of the tracery in the niches of the minarets of local mosques. The vave at Adalaj (Burgess, op. cit., 10-13) is cruciform, with three main flights down to the first landing. Other vāvs occur scattered throughout Gujarat from Baroda northwards; one of these, at Mandva on the left bank of the Vatruk river, is of peculiar construction, having a brick circular shaft with chambers in three storeys on one side reached by spiral stairs within the wall of the shaft itself.

The Northern Indian $b \bar{a}$ olis are not dated; that at the darga $\bar{a} h$ of Nizāām al-Dīn is said (Sayyid Aḥmad Khān, Athār al-Sanādìd, Lucknow edition 1900, 42) to have been built by the shaykh (636-725/1238-1325) himself, and it is probable that other examples date from the same approximate period.

\section{Canals*}

Canals were certainly known in India before Muslim times, but there was a great extension of their use in the early Delhi Sultanate, certainly under Ghiyāth Dīn Tughluq and his son Muhammad b. Tughluq (some details in the anonymous Sìrat-i Fìrūz Shāhì, ms. Bankipore, 159-61). The canal systems were greatly expanded under Fìrūz Shāh of the Tughluq dynasty, the best known man-made example being his west Yamuna canal (later re-excavated and re-aligned under Shāhjahān); "man-made" is used here because former river-beds, cleared of silt, which might fill up during the annual rains, were in use as natural canals. The man-made canals were of two classes, "perennial" and "inundation", the former drawing off water from a river at about lowwater level, sometimes with the help of a weir (although this may reduce

\footnotetext{
* “Nahr, 2. In Muslim India,” EI, VII, 909-10.
} 
the water-supply lower downstream); inundation canals take water from rivers at a level considerably higher than the normal low-water level, and consequently provide water only in the ice-melt and flood seasons, say from May to September.

The essential purpose of canals in India was for irrigation (few are navigable to any great extent), the intention of which was to bring larger areas under cultivation and thereby engender more revenue to the state; private construction of canals was therefore encouraged, and jurists decreed that the constructor was entitled to haqq-i shirb as $10 \%$ of the gross produce; if the canal had been constructed by the state on the sultann's behalf, then the sultān's haqq-i shirb went into his own privy purse. Shams al-Sirāj 'Afîf, Ta’rīkh-i Fìrūz Shāhì, Bibl. Ind. ed., 129-30, gives details of these rulings, which have been ably interpreted by I.H. Qureshi, The administration of the sultanate of Dehli, Karachi 1958, Appx. $\mathrm{G}$. The development of agriculture by irrigation and other means was regarded as so important by Muhammad b. Tughluq that he brought it under a special ministry, the dìwān-i amīr-i kūhn (Diyầ al-Dīn Baranī, Ta'rīkh-i Fìnūz Shāhì, Bibl. Ind. ed., passim, see Index.)

Other important canals constructed in the days of Muslim rule were the east Yamuna canal of the early 18th century, Fīrūz Shāh's Sutlej canal, the Mughal inundation-canals taken from the upper Ravi, the Khanwa in the Indus delta, and many more. The original works are now hard to trace, since they have been incorporated in a vast extension of canal resources made in British times. A comprehensive account of these works is in Imperial gazetteer of India, iii, 326-54; see also O.H.K. Spate, India and Pakistan: A general and regional geography, London 1954, 204-8, 465-77. 'Alī Mardān Khān's canal, which took water for the Red Fort at Delhi, tapped the Yamuna some $100 \mathrm{~km}$. upstream.

\section{TOWERs*}

The word burj in Urdū, whence it has spread into other languages of India, means always 'tower' or 'bastion', including those towers on the walls of fortified palaces whose function is decorative and residential rather than functional in any military sense, those bastions which, taking the form of a protuberance in the trace, may in fact include

\footnotetext{
* "Burj, III. The tower in Islamic architecture in India," EI, I, 1221-4.
} 
several tower-like buttresses, and also those massive bastions within the enceinte, built after the introduction of cannon, as mountings for heavy pieces of ordnance.

\section{Delhi}

The earliest Muslim invaders had found a land already well provided with fortified works, of which Hindu India had a long tradition which remained active later wherever Islam had not spread; their earliest static military enterprise was the occupation and modification of existing works. In Delhi, for example, it was the old fort of Prithvīrāja Chauhān, Qil'a Rāy Pithorā, which was garrisoned first by Muslim troops, and within the citadel of which (Lālkōt) the earliest Indian mosque, named Quwwat al-Islām, was erected in 587/1191 by Quṭb al-Dīn Aybak. The curtain here is flanked by closely spaced towers, defended by a broad ditch, with gates set in the re-entrant angles of powerful bastions formedby a bulge in the trace with several small counterfort towers. Most of the standing fortification is probably of the period of 'Alä' alDīn Khaljī, c. 704/1304 (Beglar, ASIR IV, 1874), probably following the trace of the Hindu work; the towers are for the most part counterforts of shallow projection. The walls of 'Alā' al-Dīn's newer capital Sīrī were built at about the same time to the north-east of the old capital (Campbell, Notes on the history and topography of the ancient cities of Delhi, in JASB, xxxv, I [1866] argues that Sīri was the name given to the 'Qutb citadel', i.e., Lālkōt, and that the site now generally accepted as Sīrī was built by Bahlōl Lōdī in the 16th century; this is convincingly refuted by Cunningham, ASIR I, 1871); some stretches of walling remain, with semicircular battered bastions spaced about a bow-shot apart, capped like the walls with merlons, and with a continuous chemin de ronde supported on an arched gallery. The principles employed are similar in the new capital, Tughluqābād, built in 720-3/1321-3 by Ghiyāth Dīn Tughluq, and its appendage 'Ā dilābād built by Muhammad b. Tughluq in $c .725 / 1325$ : the walls of both, of rubble core faced with rough quartzite ashlar, are punctuated with strongly projecting semicircular bastions, and these and the walls, both of which are strongly battered, have three tiers of defence consisting of external gallery, main mural gallery, and battlements, the latter with two ranks of loopholes. The rock outcrop below the wall trace is scarped, over which is a bolster plinth faced with masonry to the base of the wall proper, forming both a continuous buttress and a protection against sapping. The bastions 
are most closely spaced around the citadel. Gates open between two bastions, and are often defended by barbicans. 'Ādilābād is defended further by a bailey and outer wall. Within many of the towers are the remains of grain silos. The tomb of Ghiyāth al-Dīn forms a strong fortified outwork to the south of Tughluqābād, with similar bastions except for the absence of an outer gallery.

Besides 'Ādilābād, Muhammad b. Tughluq formed yet another 'city of Delhi' with the building of Jahānpanāh (725/1325), the walls of which enclosed the ground between Qil'a Rāy Pithorā and Sīrī; these have semicircular counterfort bastions similar to those of 'Ādilābād, though without the external gallery, and are at one point interrupted by a dam and sluice, called Sāt Pulāh, obviously to retain water within the walls for the use of the defenders.

This reign saw the Delhi diaspora and the transfer of the capital to Devagiri in the Deccan, renamed Daulatabad. The three lines of defences between the pass and the acropolis consist of walls with regularly spaced battering round bastions, projecting less than in the contemporary northern work, and without exterior galleries. Bastions round the gates are larger and of greater projection, some being of the form of a half ellipse; a succession of rounded bastions forms a hornwork with two courts where the city is entered over the lower moat. The many modifications made during the Bahmanī period are referred to below.

Fīrūz Shāh Tughluq was responsible for building yet another 'Delhi', his new capital of Fīrūzābād (755-71/1354-70), which was later sacked by Tìmūr and of which no traces remain beyond his citadel, or kōtla, much ruined. Walls and towers here have a strong batter; the towers are semicircular, and it is probable that they were crowned with open kiosks (chhatris). Traces of low barbicans outside the gates have angle towers of smaller dimensions, presumably for the use of sentries. The contemporary complex housing the Qadam-i Sharif, which, protected by its sanctity, escaped the Tīmūrid sack, is protected by a strong bastioned curtain which shows the principles of Fìrūz's fortification better than the ruined $k \bar{o} t \bar{l}$ : walls and towers have lost the bolster plinth, and defence against sapping is effected by small box-machicolations. Many buildings of this period, especially tombs and darga $\bar{h} s$, are contained within fortified enclosures. At this time the burj is developed as an ornamental feature: mosque enclosures and $i d g \bar{a} h$ walls regularly show angle and end bastions, capped by circular or square chhatris or by low domes, always with the typical batter, which is imitated in those purely 
decorative buttresses, where the slope is carried up into a guldasta finial, which flank the gates of Fìrūz's mosques in Delhi (Begampurī, Khirkī, Sanjar, Kalān Masjids), of which echoes occur in the Lōdī buildings at Delhi, and in Jaunpur and elsewhere. Fīrūz Shāh Tughluq is known to have restored many of the buildings of his predecessors, and, though he speaks of having restored the towers of the tomb built by Iletmish - i.e., the tomb of Abu'l-Fath Maḥmūd Nāṣir al-Dīn at Malikpur - it is probable, from the style, that the corner towers are, at least in their upper stages, Fīrūz's work.

It seems that the later Tughluqs and the "Sayyids" created no new fortified works, except that it is recorded that Mubārak Shāh in 824/1421 replaced the walls of Lahore, destroyed by Tīmūr, by a mud fort. His own tomb (836/1433), however, lies in the fortified complex of the small town of Mubārakābād, yet another "city of Delhi", where the towers are small but otherwise differ little from preceding patterns. Sikandar Lōdī is said to have built a fort at Agra in 908/1502; but there had already been a fortress here, and the present fort is the work of Akbar, and it is thus difficult to assess how much of the trace is due to Sikandar.

\section{The Deccan}

Here again there were many fortified Hindu works which the Muslims found and later occupied, and to some extent modified even in their earlier years. Their first original production seems to have been at Gulbarga, where the thick (16 m.) walls are doubled, with towers on the inner curtain. All towers are very solidly built, of semicircular form; many have barbettes added later for the use of artillery, and this modification is to be attributed to the 'Ādil Shāhīs of Bijapur, since an inscription on the Kālā pahār Burj claims that in 1066/1655 "Muhammad... rebuilt every burj, wall and gate" (Haig, EIM, 1907-8). Within the enceinte, on high ground, stands a large isolated masonry bastion, the mounting for a large piece of ordnance. In Bidar, already a Bahmanī outpost, whither the capital was transferred by Ahmad Shāh al-Walī, there had been a double line of Kākatiya fortifications in 722/1322 (D̄īyā al-Dīn Barnī, Ta’nkh-i Firūz Shāhì, Bibl. Ind., 449) when it first fell into Muslim hands; in the rebuilding of 832-5/1429-32 Persian and Turkish engineers are known to have been employed, as in a further rebuilding in the time of Muhammad Shāh III (867-87/146382) by his wazìr Maḥmūd Gāwān, after the introduction of gunpowder 
in the Deccan. The older round bastion is largely superseded by the polygonal variety, although some round and square towers remain; large trapstone blocks with fine joints in the older work give way to smaller rubble set in deeper beds of mortar in the repairs and restorations. The towers are solid at the base, defended by chambers at the same level as the curtain battlements and by their own battlements one stage higher; like the curtain, they are further defended by heavy box machicolations. At the angles of the irregular trace, and also standing free within the enceinte, are large and massive bastions, some of imported trapstone and others of the local red laterite, built as mountings for heavy pieces of ordnance; these may be, as in the Kalyānī Burj, defended by two or more successive machicolated curtains, and may provide room for the accommodation of a large number of troops. The walls of Bidar town are of the Barīd Shāhī period (built 962-5/1555-8); the 37 bastions include the massive Mundā Burj of two defended stages, approached by steps built on the back wall of the bastion itself, which mounted a long-range gun. The disposition of the bastions is here, as in the case of the fort curtain, variable: they are closest at those points in the curtain most vulnerable to attack. The Chaubāra in Bidar town, presumed to be part of Ahmad Shāh's defences, is a tall conical watchtower, $23 \mathrm{~m}$. high, commanding a view of the entire plateau and lowlands, with a massive circular plinth with guard-rooms and an internal stairway.

There was much activity in the construction of military works in the Deccan in the heyday of the Bahmani dynasty; Daulatabad, Bijapur, Gawilgarh, Elichpur, Narnala, Parenda, Naldurg, Panhala, Warangal, Golkonda, Mudgal, Raichur, etc. At Daulatabad the old defences were strengthened and heightened, in smaller stone or brick, and one striking example of this is the building up of a bastion in the second court of the entrance hornwork by filling in the old embrasures, which were the same height as those of the curtain, adding a high upper storey while maintaining the batter of the walls, and building a projecting arcaded oriel supported on corbels of re-utilized Hindu work as a further watch chamber. There are thus two upper defensive chambers, pierced with embrasures for small cannon, over the solid base. At Parenda - like most Deccan forts, attributed by local tradition to Maḥmūd Gāwān but in fact probably earlier - the towers on the fausse-braye and curtain are defended by heavy bartizans. At Kandahar (ARADAS, 1921-4, 3) are circular bastions on the fausse-braye but rectangular bastions on the curtain, with inscriptions of 998/1588 giving Turkish names as the responsible engineers. At Kalyani polygonal and round towers on 
the curtain have the merlons replaced by box machicolations on corbels, while a conspicuous bastion within the barbican has a mural chamber defended by bartizans, with a barbette on the battlements, which have two tiers of loopholes. The old Kākatīya fort of Golkonda, ceded to the Bahmanīs in 766/1364, has three successive curtain walls which show a variety of towers: square, cylindrical, conical, polygonal - the mantlet before the citadel gate has a burj in the form of a half-tetradecagon - and scalene, and, on a later enclosure, a 'nine-lobed' bastion of strong projection, each of whose 'lobes' is a quarter-circle on the exterior face. This last feature is found also at Naldurg. At Bijapur the city walls, of the time of 'Alī 'Ādil Shāh I (completed 973/1565), which are of uneven quality since each noble was responsible for one section, have some 96 bastions, mostly semicircular, with embrasures protected by stone hoods. Many are later modified to take heavy guns (inscriptions of Muhammad and 'Alī II), one, the Farangī or Tābūt Burj built to accommodate several large jinjāls. On high ground, well within the walls, is the Üprī or Haydar Burj, a massive cavalier oval in plan and some $24 \mathrm{~m}$. high, built (insc. 992/1583) to mount a large (over $9 \mathrm{~m}$. long, $15 \mathrm{~cm}$. bore) piece of ordnance. The Sherza Burj, one of the largest, is built out from the curtain, to which it is connected by a broad passage forming a 'head and neck'.

Later fortifications in the Deccan, constructed or rebuilt during the Marāthā supremacy, generally follow the patterns of the Muslim period.

\section{Mughal period}

Bābur's conquest in 932/1526 brought no new style of building in its early days, although his interest in the Hindu fortress of Gwalior communicated itself to his successors who developed the palace-fort par excellence. His son Humāyūn began yet another city of Delhi, called Dīnpanāh, but this was razed by the Afghan usurper Shēr Shāh, who commenced building his own capital of which now little but the citadel remains, constructed on a site identified with the ancient Indraprastha and known as the Old Fort (Purānā Qil'a, Qil'a-i Kuhnā). The walls and widely spaced bastions of the trapezoidal trace are of roughly coursed rubble, while the gates, each flanked by two strongly projecting bastions, are of fine polychrome ashlar. The towers are semicircular, solid to a height of $5 \mathrm{~m}$., with several tiers of superposed rooms and galleries, with small box machicolations; one gate has an internal 
machicoulis, a rare feature in India. Humāyūn's re-occupation of the Purānā Qil'a added nothing, and Mughal building of forts starts with Akbar. Sikandar Lōdī's fort at Agra had fallen into ruin, and was razed and rebuilding started in 972/1564. There are semicircular bastions on the inner and outer curtains, the same height as the walls; the inner ring is much higher than the outer, reaching $30 \mathrm{~m}$. Outer and inner bastions are concentric, and both have crenellated battlements defended by two or more ranks of loopholes, some protected by stone hoods for downward firing. The inner Delhi Gate on the west is defended by two magnificent half-octagonal bastions, with a blind arcade at ground-floor level finely decorated with marble and polychrome ashlar, a wide arch in each face on the first floor with an exterior balcony, and a defended chamber above with two ranks of loopholes. The battlements above have some merlons equipped with stone hoods, and others are pierced. Each of these towers is topped by a chhatri. The work throughout the walling is in red sandstone ashlar over a rubble core. Akbar's new city (979/1571) of Fatehpur Sikri is undistinguished in its fortification: the outer single curtain is incomplete, and its half-round bastions are simply bulges in the trace. The citadel was enclosed rather than fortified, though boasts one large bastion, the Sangin Burj, semi-octagonal with an internal hall, for a guard which was probably ceremonial rather than defensive. The new city was soon abandoned, and Akbar moved back to Agra, which was later occupied by his son Jahāngīr. From his time presumably dates the Muthamman Burj (later called Saman ['Jasmine'] Burj), a half-octagon projecting on the river side of the fort surmounting a semicircular buttress; it is of two storeys with open arcades on each face, with fine pietra dura decoration. Some of this work is probably of the time of Shāhjahān, whose principal buildings were, however, at Delhi and Lahore. The New Fort at Delhi (Lāl Qil'a) was commenced in 1048/1638 and completed within ten years. The nearly rectangular trace has semicircular bastions at regular intervals, defended by one tier of loopholes at about half their height and by two rows in the battlements; the merlons are decorated by cusping. Each tower is surmounted by a chhatri. Similar towers on the barbicans are of the time of Aurangzib. The north and south bastions on the river front are larger, two storeys in height above the level of the courtyard, crowned by chhatrīs (Shāh Burj, Asad Burj); between them is a larger half-octagon, the Muthamman Burj, originally known also as Burj-i Țilā on account of a gilded copper dome; the five sides which overlook the river are filled with marble screens. Lahore Fort, built by 
Akbar at about the same time as Agra Fort (Abu 'l-Fazl, A' Blochmann's trans., i, 538) has a similar Shāh Burj, also called Muthamman Burj, insc. showing completion 1041/1631-2, of great size (45 m. diameter). Manucci in his Storia do Mogor says of these works: 'At each place [Delhi, Agra, Lahore] there is a great bastion named the Xaaburg [Shāh Burj] ... they are domed and have architectural adornments of curious enamel work, with many precious stones. Here the King holds many audiences for selected persons, and from it [sic] he views the elephant fights...' (Irvine's trans., ii, 463). Certainly also the Muthamman Burj in Delhi was used for the emperor's daily darshan (ceremonial showing himself to the people).

These Mughal burjs had no pretence of being fortified works, and thus what started as a grim military work was transformed into a vehicle for Mughal art. The walls of Shāhjahān's Delhi were bastioned, certainly; but these were so rebuilt in the British period that it is not possible to recapture the Mughal arrangements.

\section{ChHATris*}

The chhatri (from the diminutive of the Skt. chhattra = 'umbrella') usually refers to a small, canopied structure placed at the junctions of the chemin de ronde of a fortification, or as decorative elements at roof level on mosque, tomb or other building, or as simple cover of an inhumation less imposing than a tomb proper. In certain architectural styles (e.g. Bengal, Malwa) the chhatri may cover a minbar or, as in the Red Fort in Delhi, may serve as a baldachino intended as the ruler's seat.

The earliest uses seem to be in fortification, where a chhatri at the angles of a wall-walk affords protection from the elements for the guard; heavy domed rooms, with almost solid sides, often as the upper part of a burj. The best existing example is in the corner towers of the fortified Khirkī mosque in Delhi (Yamamoto et al., Architectural remains of the Delhi sultanate period, 3 vols. Tokyo 1967, ii, Pl. M.7); by the time of the fortified Qadam-i Sharif, the chhatri has assumed its characteristic form of a domed canopy supported on four strong pillars, with heavy protecting eaves (Yamamoto, op. cit., ii, Pl. 0.8); thereafter it continues as a regular feature, on four, six or even eight supports, on buildings

\footnotetext{
* “Mizalla, 5. In Indo-Islamic architecture,” EI, VII. 194-5.
} 
of the Delhi Sultanate, whence it spreads to most of the provincial styles. Among the earliest royal tombs at Delhi are the chhatris over the graves of Rukn al-Dīn Fìrūz Shāh and Mu'izz al-Dīn Bahrām Shāh at Malikpur outside the complex known as Sultān Ghārī (S.A.A. Naqvi, Sultan Ghari, Delhi, in AI, iii [1947]). There are sporadic uses of the chhatri in the "Sayyid" and Lōdī periods as a sort of lantern crowning the dome of a tomb, e.g. in the "Pōtî̀" of the "Dādī-Pōtî̀" complex near Hauz Khāṣs, the tomb of Mubārak Shāh in Mubārakpur, and (according to old illustrations) in the tomb of Shēr Shāh in Sasaram (H.H. Cole, Preservation of national monuments. Report for...1882-3, Calcutta 1883, two Pls.; also in J. Ferguson, History of Indian and eastern architecture, London 1876, Ill. 288; this was later replaced, by a British engineer, with an incongruous heavy stone kalaśa-and-ämalaka finial). In Lōdī times the pillars supporting the dome become much thinner (e.g. in the Jahāz Mahall at Mehraulī in south Delhi; Yamamoto, op. cit., ii, Pl. O.22), and this tendency persists into the Mughal period. Chhatris are used with great freedom on all roofs, and with the reintroduction of the minaret under the Mughals, invariably form its topmost storey, or crown corner turrets as in the tomb of I'timād ad-Daula in Agra, or the tomb of Mīrzā Muqīm Abu'l Manșūr Khān (Șafdar Jang) in Delhi. In Akbar's tomb at Sikandra, outside Agra, is first seen the expedient of uniting two chhatris at the corners of the building under one common projecting eaves-pent, leading to the common Mughal practice of a string of conjoined chhatris, as a feature above doorways, etc.: a row of seven above the Lahauri gate of Delhi Fort, thirteen surmounting the central arch of the Buland Darwāza in Fatehpur Sikri, eleven over both front and rear elevations of the ornamental gateway to the Tāj Mahall, nine over the central arch on each face of the tomb of "Safdar Jang", which is directly modelled on the Tãj gateway, etc. The cupola over the baldachino (nashìman-i zill-i Ilähī) in the dīwān-i 'āmm in the Red Fort of Delhi is unusual in having a "Bengali" roof with curved cornices, an innovation made popular in Shāhjahān's reign. 


\section{SITES AND MONUMENTS}




\section{AhmadABAD*}

Once the capital and still the premier city in Gujarat, Ahmadabad (Ahmedabad) is an old walled town standing on the east bank of the Sabarmati river, which has throughout the centuries enjoyed the reputation of being one of the fairest cities in the whole of India. The advent of industrialization, with mill and factory chimneys belching smoke, the streets filled with motor transport of every description, and urban sprawl and overcrowding resulting from the recent population explosion, have somewhat diminished Ahmadabad's glories; but most of its loveliness is still to be found, and it has been sadly unappreciated by most modern travellers.

Ahmad Shāh founded his new capital to the north of the old Hindu settlement of Ashaval. The new city, which replaced Anahilvada-Patan as the capital, covered an area of about 500 ha. The enclosure walls, some $5 \mathrm{~m}$. to $6 \mathrm{~m}$. tall, had original fourteen gates, and were defended by towers and bastions every $50 \mathrm{~m}$. or so; but an 18th-century source ascribes these to the time of Mahmūd 'Begrā', giving a chronogram, saying the specified parts were the responsibility of separate nobles. The walls are even described as being of Mughal date, since their internal construction is of red brick, but this is not referred to in the Mughal sources. None of this, of course, precludes the possibility of there having been an earlier mud or mud-brick wall.

On the west the city was defended by a wall following the almost straight line of the river bank. A temple to the goddess Bhadrakāli in pre-Muslim times has now utterly disappeared except for the reflection of its name in the Bhadra, of Bhadra Qil'a, the internal fort which constitutes the citadel, a square enclosure originally housing the royal palaces, and separated from the Maidān-i Shāh (royal grounds) to its east by a double gateway, of which the inner member stands imposingly between two enormous (later) circular bastions. (Excavations in recent times have revealed many fragments of Jain and Hindu temples in the

* "Mosques and Tombs," in Ahmadabad, eds., G. Michell and S. Shah, Bombay 1988, 30-119. [Hijra dates and diacritical marks added by the editor.] 
citadel area. There is now a comparatively modern Bhadrakālī temple within the area of A'zam Khān's caravanserai of 1047/1637.)

\section{The legacy of Islamic building before Ahmad Shāh}

Before we proceed to consider the mosques and tombs which are the glory of Ahmadabad we must recapitulate the principles of the growth of the Gujarati Islamic style. Islam has been implanted in Gujarat well over a century before the political rule of the Delhi Sultanate was shaken off and Ahmad Shāh's Sultanate came into being, with mosques established from the beginning, and the form of the mosque which had already evolved in Gujarat was there as an exemplar for Aḥmad Āhāh and his successors. The earliest mosques in Gujarat, to be sure, were mere improvisations arranged into a mosque form from pillaged temple material, as has happened all over India in the initial phase of an Islamic conquest, and were exemplified in the large but for some time ruinous Ādīna Masjid at the old capital, Patan. The Tānka Masjid at Dholka, in 762/1361, with its haphazard pillars from which human forms have been effaced, offers an extant example. Two further mosques will suffice to illustrate the development of the style, the Jāmi Masjids of Bharoch (722/1322) and Cambay (Khambayat) (725/1325). The former is entirely in the indigenous trabeate style, with an open prayer hall, its roof supported by richly carved pillars derived directly from the wealth of Hindu and Jain temple architecture. The exterior is comparatively plain, the outer walls being ornamented with nothing more than modest stringcourses, and a series of carved buttresses which indicate the presence inside of mihrābs; the only concession of traditional Islamic forms appears in the three large soaring domes which, with many smaller ones, dominate the skyline. The interior of the roof, though, shows the ornate cusped patterns and square coffered ceilings characteristic of the temple style, which were indeed probably temple spoil adapted to the purpose of the mosque. The Cambay mosque, on the other hand, is more assertively Islamic, for the façade of the prayer hall shows three well-proportioned arched openings, the central one taller than those flanking it, although the hall behind is in the trabeate style; the façade is also surmounted by a row of merlons of characteristic shape. The great courtyard has two water cisterns (tanks) underneath it - a typically Gujarati feature. A colonnade runs the length of the southern side of the mosque, its central part being a two-storeyed dodecagonal rotunda, entirely of pillars of typically Hindu 
or Jain style, which were doubtless produced by local craftsmen. The rotunda originally supported a large corbelled dome, with a superb tombstone below. The mosque walls are plain, as before, with simple Jain-like stringcourses, and the outer walls show alternate deep and narrow courses as in the Khalji style, Delhi; but the pillared eastern porch is entirely in the local temple style, with seating slabs with sloping back rests (kakșäsanas).

\section{Monuments of the reign of Ahmad Shāh (814-46/1411-42)}

The earliest dated mosque in Ahmadabad is that of Ahmad Shāh himself, built in $817 / 1414$, in the south-west corner of the citadel, probably a private mosque for the use of the sultan and his immediate train (and hence other arrangements would have been necessary for the city's congregational mosque; probably a temporary structure served such needs under the great Jāmi` Masjid, described below, was completed). Here we have the immediate descendant of the Cambay mosque on a smaller scale: again there is an arched prayer hall façade of three arches, with the central bay raised above the level of the remainder, with the internal arrangements in the trabeate style (the central bay reveals two small pillars with a heavy stone lintel above them); and again the roof parapet is capped with a row of merlons. But here the central bay is flanked by two great but sparsely ornamented buttresses, which terminate at parapet level - the turrets above them having presumably fallen in the great earthquake of 1819; but even these are not an innovation of the Gujarati style, as there is a precedent for them in the mosque of Hilāl Khān Qāzī at Dholka. There is no evidence to determine whether these turrets were in fact minarets (the staircases in the thickness of the buttress give access to the roof, from where the call to prayer could have been given); but it is tempting to see them as the forerunners of the paired minarets which, at least in the earlier stages of the style, flank the central opening of the prayer hall, a peculiarly Gujarati feature. The raising of the central bay above the side roof levels has two consequences: firstly, the general appearance of the prayer hall is greatly enhanced by the change of level, relieving what could otherwise be a monotonous aspect in a long low building: and secondly, this practice allows air and light to enter the prayer hall much more freely, providing a sort of clearstorey. The vertical gap between the two roof levels is filled with stone screens, which reduce possible glare from oblique rays of the sun, and also prevent the entry of birds, and 
driving rain, at roof level. Both the clearstorey and the stone screens are to become further characteristics of the Gujarati style.

A smaller mosque, built within the next year or so, is that of Haybat Khān, a relation of Aḥmad Shāh; built almost entirely of temple spoil, the exterior aspect is severely plain, except for the five half-round buttresses behind the mihrāb wall; the corner buttresses taper, in the manner of the Tughluq style of Delhi. The interior shows all the rich flamboyance of the indigenous Hindu-Jain temple craft. The noble central dome - again over a chamber raised above the side aisles - reveals within that it is the roof of a temple mandapa taken over in its entirety. The curious feature here is the pair of slender cylindrical turrets set at the end of the parapet over the central arch, unornamented and obviously non-functional, rather like thinner versions of the pillars over the central arch of the 'Arhā'̄i din kā Jhōmprā Masjid at Ajmer. They represent, no doubt, a further stage in the search for the Gujarati minaret form; but they are minarets only in a psychological sense.

A modest mosque, undated, is that of Shakar Khān (probably a son of Aḥmad Shāh), near the Kālūpur Darwāza, possibly of about this time. It is almost entirely devoid of decoration (the pillars were obviously cut for the purpose), and is entirely trabeate, of the open pillared hall style. Good corbelled domes over the five main bays of the prayer chamber, which is of impressive strength. An unusual feature is that the pillars on the courtyard side are grouped in threes from east to west. Five half-round external buttresses mark the position of the internal mihrābs and these have rather more carved decoration. A staircase leads to the roof, and there is no trace of any sort of minaret.

Next comes the little mosque of Sayyid 'Ālam, c. 823/1420 (the inscription is fragmentary), where the central chamber is of three arches, considerably taller than the side wings which are entirely in the trabeate style. This also has a richly decorated interior, and fine pierced stone window screens; but here the central arch of the façade is flanked by a pair of ornate buttresses which end at parapet level in semicircular platforms supported by heavy stone corbelled brackets; though there is now nothing above them, perhaps we have here at last the beginnings of the true Gujarati minaret, for the construction of this mosque was concurrent with that of the great Jāmi 'Masjid, Aḥmad Shāh's greatest work, to which we now turn.

The Jāmi 'Masjid was completed in 827/1424, although it had obviously been many years in building. The harmony of solids and voids of its noble façade makes it one of the loveliest mosques in India, 
and when it was built it was probably the largest in the subcontinent (although later eclipsed in size by those of Lahore and, much later, Bhopal). The whole conception is grandiose, for the vast paved courtyard is a rectangle of about $75 \mathrm{~m}$. by $66 \mathrm{~m}$; the north, east and south boundaries are enclosed by open colonnades along the stone walls, with a long ablution tank in the middle-here, unfortunately, the area is protected from the sun by a modern roof on thin struts, looking all too much like a bicycle shed! The west side is filled by the prayer hall, the builders having avoided any suspicion of monotony in such a long structure by arranging the roofs on three levels: the extreme north and south chambers are the lowest, opening to the courtyard by five pillared bays of unequal size, not structurally arched but rather showing an arch-shaped infilling at the top supported on corbels, a device known also in the early buildings at Dhar and Mandu; the central chamber is of three arched bays on two levels, the roof of the side bay at the second level carried on pillars with perforated stone screens between them, with a similar arrangement carrying the central bay above the side bays. The whole of the western chamber is a great hypostyle hall, a forest of 260 pillars, all with restrained decoration directly derived from the temple styles, so disposed as to form three rows of five square bays each, every one with a dome above. The three front central bays, with their extra height provided by the clearstoreys, are most impressive, the middle one forming a sort of central rotunda. The two tall pillars which are seen from the courtyard within the central arch have an additional embellishment in the form of a cusped semicircular arch carried on corbels just below the top beam, again a feature of Gujarati temple architecture as at, for example, the magnificent Sūrya temple at Modhera. The façade shows, flanking the central arch, sumptuously decorated buttresses, the bases of the minarets which fell in the 1819 earthquake; and these are certainly real minarets at last, as an old drawing makes clear.

A grandiose conception indeed; but the mosque alone is only part of Aḥmad Shāh's vision. The mosque is built so that its northern wall lies along a royal processional way, leading eastward from the Maidān-i Shāh already referred to, which was entered at its eastern end by a great triple gateway (T̄̄n Darwāza), its central arch wider than the flanking ones, two buttress projecting from the inner piers similar to the decorated minaret-bases in the mosques, with a deep parapet above in which there are three roofed balconies projected on corbelled brackets. The Maidān-i Shāh (which has been completely obliterated by modern 
development) extended from the Tīn Darwāza to the east gateway of the citadel, with streets off it to the north leading to quarters ancillary to the necessities of the palace. It had a central chabutra (raised platform) which may have formed part of the original system for the royal water supply (a neighbouring street bore the name 'Karanj', a corruption of the Persian kariz, 'underground water channel'; and clay pipes were found here during reconstruction work). The maidan also had a postern on its southern side. The 'royal precinct' scheme is completed by two other works: an enclosure set aside in Ahmad Shāh's time, east of the mosque, to contain his tomb, and a further enclosure to be dedicated to the tombs of the royal ladies.

\section{Monuments of the reign of Muhammad Shāh (846-55/1442-51)}

The two works last mentioned were in fact completed in the reign of Ahmad Shāh's son and successor Muhammad. The tomb of Ahmad Shāh, itself unspectacular as a building, is nevertheless of importance in architectural history: the pillars supporting the roof are composed so as to form a sort of cloister around the square domed central chamber, which is separated from the cloister by perforated screens of stone in square patterns: another characteristically Gujarati feature. The tombs of the queens (Rānī ka Hāzīra) are, by contrast, set in an open courtyard, which stands imposingly on a very high plinth, within pillared galleries; and here there are exquisite screened windows separating the outer corridors from the outside world. The tombstones of marble, inside the courtyard, are superb examples of the stone carver's art.

This reign sees the beginning of another great architectural project, his time at Sarkhej, some $10 \mathrm{~km}$. south-west of Ahmadabad, with a fine monumental tomb and an elegant mosque. The tomb was built for Shaykh Aḥmad Khaț̣ū, known as 'Ganj Bakhsh', who died here in his retirement at the age of 111 lunar years in 850/1446. Essentially a domed central chamber surrounded by four ranges of pillared corridors, it is the largest of its type; the central chamber is separated from the outer corridors by perforated stone screens, arch-shaped below with the commoner small square screens above, giving the outer façades a two-storeyed effect, although the interior is the one tall storey. The central dome - which sits rather uneasily on its support, since this is an unequal octagon, as though its builders were unaccustomed to using this form with fluency - is surrounded by smaller domes over the bays of the outer corridors. The mosque, by contrast, is a completely open 
building with the arch used not at all, the western prayer hall presenting a view of a forest of simple pillars, taller than those of the one-bay-deep corridors which surround the remaining three sides. An open pavilion to the south of the tomb completes this stage of the building; but the sanctity of the site attracted an immense but completely harmonious development at Sarkhej towards the end of the 15th century under Maḥmud 'Begrā'.

\section{Monuments of the reign of Outbuddin Ahmad Shāh (855-62/1451-58)}

A few buildings produced in the short reign of Qutbuddin Ahmad Shāh show the progression of the same style. The mosque in the city carrying his name (which, however, bears the date 853/1449, in the previous reign) is on a modest scale and similar to Aḥmad Shāh's mosque, except that the central buttresses, the minaret bases, are more robust and exquisitely decorated. The mosque of his mother ('Bībìî̀') in the Rājpur locality (858/1454) is instructive, for one of its paired central minarets is still standing intact, showing three circular galleries round the tapering shaft, supported on heavy corbels, the topmost level of the minaret opening by an arched door to the courtyard and capped by a conical roof. In this mosque instead of open pillared chambers in the north and south wings of the prayer hall are three elegant arches, the side ones closed by seat-backs, the taller central one open to the courtyard. The mosque and tomb of Malik Shā'bān both bear inscriptions with the date 856/1452; they are widely separated, since the mosque is in the city and the tomb lies in Rakhiyāl, on the eastern outskirts, adjoining a tank built by the malik's order which has now been converted into a stadium. And both present unusual features: the tomb is a pillared square hall inside a large square enclosure with corner chhatris, its central chamber carrying a large dome without a clearstorey, with the surrounding colonnade entirely covered by flat roofs except for very shallow domes at the corners. The mosque façade is open, revealing a double row of pillars in the front, with openings of unequal size; but the plan is most remarkable: the westernmost section is a chamber three bays wide, each with a mihrāb; two bays flanking this to the north and south, again with mihrābs, lie forward of this western end, and the main hall, wider again by one bay on each end (with a further mihräb niche in each), is set further forward still. There is a single large dome. The western view of this mosque has therefore as stepped appearance, which J. Burgess (The Muhammadan architecture of 
Ahmadabad, 2 vols., $A S W I$, vii and viii [= ASI NS, xxiv and xxxiii], Calcutta 1900 and 1905) and others following him have likened to a Hindu mandapa, declaring further that the mosque is nothing but a converted mandapa. But this seems unlikely, since the mandapa is a generally an open structure, whereas this mosque has of course a solid stone wall at its western end; it seems more likely that it may have been inspired by a mandapa shape, but even so it is curious that this is the sole example of this form. Also in this reign the Kankāriyā tank was excavated, 1 $\mathrm{km}$. outside the city wall, a polygon of 34 sides with a circuit of 1.25 $\mathrm{km}$.; steps of cut stone descend to water-level, and even so utilitarian a feature as a sluice is tastefully decorated with carving. The area around the tank was used as a camping-ground in Mughal times.

\section{Monuments of the reign of Mahmūd Shāh 'Begrāa' (862-917/1458-1511)}

The Gujarat style reached its apogee during the reign of Sulțān Mahmūd 'Begrā', who reached out beyond the bounds of Ahmadabad, founding new cities at Junagadh, Champaner and Mahmudabad (of which the first two cannot concern us here), adding greatly to the building complex at Sarkhej, and continuing to grace Ahmadabad with exquisite examples of the building art. Of these perhaps the earliest are the mosque and tomb of Sayyid 'Uthmān, c. 864/1460, at Usmānpur across the river; the tomb is a beautifully proportioned domed building, although it appears very low for its length, entirely constructed in the pillared style (but with the enclosing stone screens now unfortunately missing), and the mosque also has the open pillared façade with no arches. In both cases the employment of paired pillars at intervals gives additional interest to the scheme. Here the dome is handled with greater competence in earlier examples, for its circular base rests on a dodecagon, supported by extra pillars surrounding the tomb chamber. The mosque has tall minarets, placed here at the ends of the façade rather than centrally, well decorated with their six storeys, but perhaps a shade too dominating. The mosque of Dastūr Khān, with an inscription of $867 / 1463$, is almost square, about $30 \mathrm{~m}$. by $34 \mathrm{~m}$., constructed on a very high plinth, with a sort of cloister, one bay deep and domed all over, on the north, east and south, running directly into the western prayer chamber; the cloister opens to the courtyard by pillars, while exquisitely carved perforated screens divide it from the outside. The ablution tank in the courtyard is connected to a reservoir of almost the same extent as the courtyard itself. Two arcuate mosques, both showing 
an accomplished integration of the arcuate and trabeate styles, are of much the same time, those of Miyān Khān Chishtī (c. 869/1465) and Bībī Achyut Kūkī (874/1469), where the minaret bases flank the central of three arches, but these again are rather over-elaborate and tend to dominate the structures. The ornate minarets of the former mosque are crowned with domical tops, but since these are not typical of the time they may be restorations of a later period. The southern bays of the prayer chamber and part of the back wall were unfortunately tastelessly altered to make the accommodation for a Railways' engineer in the mid-1870s. Bībī Achyut's mosque, and her tomb in the form of a small pillared pavilion, lie within a large rectangular enclosure with round towers at the corners, unknown elsewhere in Gujarat.

Two aberrant structures must be mentioned here, as they probably represent an extraneous influence in Gujarati architecture. These are two monumental tombs, one of Daryā Khān, once a minister of Maḥmūd Shāh, and a tomb on the Sarkhej road known as A'zamMu'azzam, popularly declared to be the builders of Sarkhej. Both are of considerable size, and unlike anything else of their period in Ahmadabad are built almost entirely of brick and in the arcuate style throughout. Daryā Khān's tomb (857/1453), the largest brick tomb in Gujarat, has a tall heavy central dome on a tall circular drum, with arched verandahs on the four sides with smaller domes above, all carried on brick squinches rather than the indigenous beam-and-bracket, and looks as though it would be more in place in Delhi; it is at best a gloomy building, and I have been told that it is haunted. The A'zamMu'azzam tomb is also square, but with a much shallower dome, here not carried on a drum, three well-proportioned blind arches on each face with an upper gallery of smaller open arches, with a great tapering domed turret at each angle, rather like those of some of the buildings of the late Tughluqs and Lōdīs at Delhi. (For completeness we might mention another brick building, Alif Khān's Mosque in Dholka, where the three domes are supported in much the same way as in the A'zamMu'azzam tomb. The scale is enormous, and in spite of its ruinous condition it is most imposing.)

These are admittedly isolated specimens; but they may have pointed the constructional way to a further arcuate building, this time in stone: the tomb (and its associated complex) of the saint (Burhānuddin) Qutb-i 'Ālam, the grandson of a famous saint of Uchh, who came to Ahmad Shāh's court and died there in 856/1452, at Vāțāa, some 8 km. southeast of the city walls. This is a two-storeyed structure, of which the upper 
storey is a square room immediately over the tomb chamber, opening to the air by three arches on each side; above this is the dome, which originally had a small chhatri in each corner (only one of these now remains). The ground floor storey has a broad inner arcade on each side of the tomb chamber, with a narrower outer arcade; and the pillar-and-lintel form of construction appears only in the entrance porch. But the builders ere evidently still unaccustomed to working with the arched form, for the outer arcades have not withstood the force of the lateral thrust, their arches have largely fallen, "and the whole is very much crippled, while the tomb without arches, that stand within a few yards of it, remains entire" ( J. Fergusson, History of Indian and Eastern architecture, London 1876, 535). The tomb was formerly attributed to the reign of Mahmūd 'Begrā', but its date is in fact uncertain. I have recently heard it suggested that it might even be early Mughal; but in my opinion no Mughal architect would have handled the arcuate style with such incompetence. Not only the minor tomb but also the mosque attached to the complex is entirely in the trabeate style.

And the trabeate style continued to be popular. The great complex known as Shāh 'Ālam, constructed over many years, is considered later below, although its foundation may have begun shortly after the saint's death in 880/1475. And Mahmūd's personal building scheme, extending the Sarkhej complex, relies very largely on the beam-andbracket. He caused to be excavated, by the side of the great mosque, a vast lake; steps down to the water were added to one side by the mosque courtyard. At the east end of the north side of the lake were built, in the shadow of the tomb of Shaykh Ahmad Khațtū, two magnificent tombs, one for Mahmūd Shāh, and another, connected by a portico, for his queen Bībī Rājbai; both of these are of the trabeate style, domed, and with the central tomb chamber surrounded by elaborate stone screens. At the west end of the south side of the lake is Mahmund's palace, again almost entirely trabeate, but now in a sad state of disrepair; and the sluice gates to the tank are again treated with great attention to proportion and decoration. (An inscription in Gujaratī prose, in Nagarī characters, declares that the tank was built by 'Madapharsa', i.e., Muzaffar Shāh, in 920/1514; this is, of course, later than the tombs of Mahmud Shāh and his queens, and the palace building, which were obviously sited with reference to a large extent of water. It may simply refer to the completion of the works, or to some other works of importance.) 
Mahmūd had by now built his new capital of Champaner. But excellent building works continued at Ahmadabad. The mosque of Muhāfiz Khān, 890/1485, a comparatively small one, has the richly carved minarets at the end of the prayer hall arcuate façade rather than flanking the central arch; and they are lower, having only three storeys above roof level, than in some other examples, investing the ensemble with more coherence. The difference in elevation between the central chamber and the side bays is not apparent form the courtyard, where the façade conceals the arrangement; but the attractive rear view of the mosque reveals this, and also the decorated oriel windows which project from the sides of the sanctuary. The mosques of Bāī Harīr, 906/1500, in Asārvā, and Rānī Rūpāvatī in the Mirzāpur quarter, of about the same date, have the minarets placed centrally, and show an interesting integration of the arcuate and trabeate forms in the elaborate north and south extensions to the prayer chamber, with their balcony openings on the façade very much in the old temple style; but although the decoration of the minaret buttresses in both of these is very ornate, there is something of a heaviness about both. The former building has the small tomb of the founder beside it, and a magnificent $v \bar{a} v$, or step-well; the latter also has an associated tomb.

\section{Buildings of the later sultāns}

Some very fine buildings continued to be produced in the subsequent reigns of Muzaffar II (917-32/1511-26), Bahādur (932-43/1526-37) and Mahmūd III (943-61/1537-54), even if the style in general was losing something of its vigour. Foremost are unquestionably the mosque and tomb of Rānī Sabrā̄̄ (commonly but incorrectly called Sipari) of 920/1514; Fergusson (op. cit., 534) describes the mosque as "the most exquisite gem at Ahmadabad, both in plan and detail." Both are of small scale, the square tomb, with an upper storey above the central chamber, being superbly screened all round, and ornately carved; the mosque is the open-fronted pillared variety, with no clearstorey, and bearing at the ends of the façade tall slender pillars. These are not functional minarets, for they are solid, sculptured along their entire height. The small Gumti mosque, in İsānpur, has similar solid minarets at the ends of the façade, and similar paired pillars at the opening, without the richness of decoration. Other mosques of much the same general design are Ibrahīm Fayyad's, on the road to the tomb complex 
of Shāh 'Ālam; an elegant small stone mosque in Pālḍi-Kochrab, sometimes known as Bāwa 'Ali Shāh's mosque, with superb merlons in many patterns of open carved tracery; Shāh Khub Sayyid Muhammad Chishtī's mosque, with an inscription of 945/1538; Darvesh 'Alī's mosque, another architectural gem, with an inscription declaring it to have been built by Bībī Khūnja in 910/1505 (thus making it the earliest of this type), which has an associated tomb; and the Fațeh mosque in the north-east corner of the city, with a courtyard tomb which appears to be very much older. They would all seem to belong to the first half of the 16th century.

Also at, or rather just outside, İsānpur is a large tomb-and-mosque complex, the Rauza of 'Imādul-Mulk Malik 'Isān, probably from the early years of Muzaffar II's reign, which has a character of its own; for the whole complex lies within an enclosure wall with pillared corridors all round; the north and south corridors lead in to the domed wings of the prayer hall, whose façade is in advance of that of the wings, and is raised above their level to form a clearstorey; the weight and thrust of this superstructure is taken by pairing the front pillars; the three arches of the central chamber soar above the level of the wing roofs, and the central one is cusped; and there are no minarets at all, nor a means of access to the roof. The tomb, entirely trabeate, stands within the courtyard, and the whole presents a harmonious and integrated structure.

Harking back to the older style of, say the Bāi Harīr and Rānī Rūpāvatī mosques is the mosque of Malik Sārang in Sārangpur, a quarter in the east of the walled city, where the malik was governor under Muzaffar II in the 1520s; the mosque may well have been started earlier, but there is no firm evidence for an earlier date. It has a broad façade of five arches, the central one raised above the level of the side bays, and more sumptuously decorated than the remainder, flanked by two massive minaret bases which are decorated with superb carved panels which seem to come from different periods (some, perhaps, since they resemble panels on the Jāmi Masjid, may have been earlier pieces of Hindu or Jain workmanship reutilized); but whatever the period they show the fluency and plasticity the local artisans were able to achieve in sandstone carving. The minarets terminate at roof level, having been taken down (by inept P.W.D. conservation work) in the 19th century; fortunately an old photograph shows the richness of the 
northern minaret. A short distance opposite the mosque on the east is what remains of what must have once been once of the most splendid pillared mausoleums, now somewhat vandalized.

The complex containing principally the tomb and tank (Mustafar-Sar) of Shāh 'Âlam, the son of Qutb-i 'Ālam of Vāṭā, was executed in 938/1532; the mosque may be later, and the minarets of the mosque may have been added later still. The tomb building, which has been described as one of the most beautiful in Gujarat, is again of the double-screened type: the outer arcade opens to the courtyard by arched openings, of which the tympana are filled with stone screens; on the west front there is also a tall portico. The internal construction is entirely trabeate, an inner square of twenty pillars forming a double corridor around the inner twelve pillars which enclose the tomb chamber itself, above which is the large dome, with a painted interior, supported on a clearstorey. This inner chamber is surrounded by rich pierced marble screens within the twelve pillars; and the sarcophagus itself is further surrounded by a perforated marble screen. The inner door to the tomb chamber, between the marble screens, is itself filled with intricate brass-work panels, but of a later date but entirely harmonious, and the device over the lintel is worthy of remark here: the sinuous line in fact represents the ancient design of the torana, especially common in Jain building. (This is by no means an innovation, for it is a favourite decorative device in the mihräbs of Gujarati mosques. It is one of the characteristic Gujarati forms to be transported to other regions.) The mosque, by contrast, is entirely arcuate; the façade is of seven arches, numbers two, four and six being wider than the other four; this results in a pleasant irregularity in the bays of the prayer hall: the larger square bays are covered by large domes, with smaller domes over the remaining square areas, and pyramidal roofs over the oblong ones. These are all carried by pendentives between the arches, much in the late Lōdī manner of Delhi. At the two ends of the prayer hall are tall minarets, set forward about $3 \mathrm{~m}$. from the façade, bearing four galleries supported on heavy corbelled brackets. The courtyard is most interesting, for there is a large vaulted reservoir beneath its floor, providing water for the ablution tank in the north-east corner of the mosque courtyard (this is also a Gujarati feature, known from earliest times, later echoed in other areas of Muslim India). Another large pillared tomb, and hundreds of graves, lie south of the main area; there 
are many smaller halls, used for the reception of guests and pilgrims at the anniversary celebrations ('urs) of the saint's death, and an imposing outer gateway to the site.

An unusual mosque, like that of Shāh 'Ālam, constructed entirely on entirely arcuate principles, is that of Muhammad Ghaus Gwāliyāri, c. 957/1550, with very fine pendentives between the arches; but its extraordinarily distinguished feature, a sort of central propylon of stone with a triple-arched entry, was ineptly dismantled by the P.W.D. in the 1880s. "This entirely changed the appearance of the façade - depriving it of all dignity" (Burgess, op. cit., 1905, 49). From an old photograph which shows this feature virtually intact, it would appear that the mosque resembled those of Jaunpur, in eastern Uttar Pradesh, rather than anywhere else. But it also has one tall minaret at the north end of the façade, six storeys above the parapet level and octagonal in crosssection - a shape found in no other Gujarati building; a larger and plainer octagonal buttress at the south end, which contains a stairway to the roof, was apparently never completed. Minarets, however, were never used in the Jaunpur style. All that can be considered typically Gujarati here is the quality of the stonework, and the restrained use of stringcourses; even the interior mihrābs are not of the usual pattern. However, it is worth recalling that Muhammad Ghaus, after his death in 969/1562, was buried in Gwalior, in a tomb which displays many Gujarati features.

In the Shāhpur quarter, in the north-west corner of the walled city, is the imposing mosque built by Shakyh Hasan Muhammad Chisht̄̄ in 973/1565; his descendants became hereditary qazis of this ward, and the building is sometimes called simply Qazi's mosque. The façade of the prayer chamber, with very fine carving, is of nine tall arches, the two flanking the central arch narrower than the rest, to be in alignment with the arrangement of pillars supporting the dome. Over the central five bays, and running the entire depth of the prayer chamber, is an upper storey of five pillared openings, with a balcony on heavy brackets projecting over the central arch. There are massive minaret bases at the ends of the façade, but it appears that the minarets themselves were never completed. Burgess (op. cit., 1905, 45) is worth quoting verbatim: "The minarets, so far as executed, are exuberantly rich in their carvings: in this respect, indeed, they are among the most elaborate in Gujarat, and the traceries of the niches have attracted much attention, as surpassing almost all others." The general design of this mosque closely resembles that of Bābā Lulu'i's mosque in Behrāmpur, $1.5 \mathrm{~km}$. south 
of the city walls; but here the upper storey is of three pillared openings only on each face, and there are also four smaller domes around it on the roof. The minaret bases are nearly the equal of those of the Shāhpur mosque in their carved decoration.

In the village of Sojali, $3 \mathrm{~km}$. outside one of Mahmūd I's new cities, Mahmudabad (now called Mehmedabad), about $22 \mathrm{~km}$. south-east of Ahmadabad, is the tomb of Sayyid Mubārak Bukhāri, built after 966/1588, a superb example of the arcuate style, although its ground floor is much the same as that of the Shāh 'Ālam tomb. The outer row of piers, however, is simply open arches without screens, and screens appear only around the central tomb chamber. This is surmounted by a large dome on tall drum, where there is the innovation of a clearstorey provided within the drum by pointed arches filled with screens. There are four small chhatris around the dome, and a large chhatri over the entrance porch, which, with the shallow domes over the bays of the side arcades, provide a lively interest to the skyline; but we have already seen chhatrīs in use at the Vāțā tomb, and they are also freely used over the entrance porches at the Jāmi ${ }^{`}$ Masjid in Champaner. The tomb, standing above the river, was formerly contained in a buttressed enclosure. There is no attached mosque, but a small tomb to the southwest, in a separate enclosure, attributed to Nizām al-Dīn, is of similar design but in brick throughout; this has a small qanāt west wall of the enclosure.

During the first decline of the Gujarat Sultanate a faction of habshis, men of African slave stock, had become powerful in some regions of the state. One prominent member of this community, Sidi Sa ${ }^{\prime} \bar{i} d$, caused a mosque to be built, in 980/1572, in Ahmadabad, just outside the north-east corner of the citadel, which can perhaps be counted the last great building in the Gujarati style before the Mughal conquest. Sidi Sa îd's mosque is again in the purely arcuate style, five bays wide and three bays deep, with broad buttresses at the ends of the façade which may have formerly supported minarets. What makes this little mosque so distinguished is its ten window screens which fill the tympana of the side and rear arches; those in the side walls, and two in the bays of the back wall, are filled with the usual square stone pierced panels in geometrical and vegetal designs, but those of the two bays flanking the central aisle are whole slabs of pierced intertwining tree and foliage designs, in one a 'palm and parasite' motif combining the superb sculptural skill of the carvings already seen on some of the minaret buttresses with the flowing form derived from that ancient Islamic device, 
the arabesque, and a 'four palms' device in the other, scarcelessly less elaborate. There are no screens anywhere else in India to compare with these in either skill or beauty, although an imitation of one design occurs in one of Akbar's early buildings in Fatehpur Sikri.

The account of the Gujarati style of Ahmadabad would not be complete without mention of the famous step-wells (vāv), whose origin was certainly pre-Muslim, which are developed in a characteristic way not evinced in the ordinary step-wells, or $b \vec{a}$ o $l \bar{\imath}$, of North India.

\section{Monuments of the Mughal period}

By the time of the Mughal conquest many of the traditional Gujarati stoneworkers had already drifted away, attracted by the wealth and greater prospects of getting work in the Mughal courts of North India. By the time Gujarat was settled under the new regime, the old craftsmen were gone; but buildings were of course still required. So either craftsmen trained elsewhere must have been drafted, or the original Gujarati craftsmen or their descendants returned imbued with new ideals learned in a foreign land. At any rate the essential styles of building underwent a radical change, with just enough of the indigenous traditions persisting to give the Gujarat-Mughal vernacular a local accent. Much of the building is, frankly, ugly and ill-proportioned, and only a selection of the better works is worth considering here.

In Ahmadabad the first major Mughal monument is the tomb of Mir Abu Turab, a leading noble who had conveyed the invitation to Akbar to invade the ailing Gujarat Sultanate in 980/1572, and who died in the imperial service in 1005/1597. The tomb is of modest size, about $12 \mathrm{~m}$. square, and entirely arcuate; a central chamber carries a dome on a square clearstorey; the surrounding arcade roof carries smaller fluted domes, as does a small southern entrance porch. The clearstorey walls still bear perforated screens, and there were originally screens around the tomb chamber which have long since been carried off (as has the marble of the tomb). It thus had considerable affinities with the late sultanate style, as exemplified in Bābā Lulu'i's or Shaykh Hasan's mosques.

Within the walled city, a little north of the citadel walls, is the Rauza of Shaykh Wajihuddin, a Sūfi scholar and teacher of great eminence, at one time a disciple of Shaykh Muhammad Ghaus Gwāliyāri, consisting of a mausoleum with an attached mosque and tank. Wajihuddin died in Ahmadabad in 997/1589, and a mausoleum was built a few years 
later during the time of Murtaza Khān Bukhāri, who was governor of Gujarat between 1606 and 1609. In the mausoleum the tomb chamber does not occupy the usual central position, but rather a square area at one end, covered by a square tower surmounted by a bulbous dome on a cylindrical drum; the rest of the roof area bears thirteen small low domes. The surrounding solid walls distinguish door and window openings (the latter come down to floor level) by the window openings being simple pointed arches, while the door openings have square heads, thus adding interest to the façade. The window openings are filled with screens, and the ensemble, in spite of its bulbous dome (seen in Gujarat here for the first time), is interesting and harmonious. It has been suggested that the tombs was originally square, with a central dome, and that the other end was added later. If this is so, the builders must have been competent in concealing any joint.

About $2.5 \mathrm{~km}$. north of the Delhi Darwāza of the city, on the left bank of the Sabarmati river, is the Shāhi Bāgh, a royal garden-palace, built in 1031/1622 by Prince Kurram, the future Shāhjahān, when he was viceroy of Gujarat. The garden fell into decay and was reduced in size, but it is obvious from the accounts of travellers (for example Thévenot) that it must have been a typical Mughal 'four-square' garden, or chār-bāgh, a square area divided into four parts by crossing central walks. The palace was (before modern additions) a large square block two storeys in height, standing over a sort of lower ground floor, or half-basement, intended to be a cool retreat in the hot weather. A large square room ('dārbār hall') in the centre of the ground floor has a splendid ceiling of moulded stucco, of a type familiar in the Mughal buildings of North India; the octagonal rooms adjoining it are contained on the upper storey with their shape emphasized by setting the central space back from the parapet of the ground floor. The builders have produced an interesting interplay of the shapes of the openings: on the river front there are four-centred arches, with a surface decoration of half-sized, blind four-centred arches, while the upper storey has three central openings spanned by beams of a shape again familiar in Mughal North India; on the garden front, however, this arrangement of the shapes of openings on the two storeys is reversed. The building has suffered much after the decline of the Mughal power by being modified for use as the residence of various officials, but the essential nobility of the main block is still apparent.

A modest but attractive building, in the middle of the walled city, is the Rauza of Shaykh bin 'Abdullāh al-Aidrus, who died in 1032/1623, 
a square structure with three arches on each side, with perforated stone panelled screens and a single dome above, whose base is decorated with a ring of cusped merlon shapes; a heavy eaves course, supported by carved brackets, surrounds the chamber.

A'zam Khān, perhaps the most efficient and industrious of the viceroys of Gujarat (1035-52/1626-42), has many building projects to his credit throughout Gujarat, whence his nickname of Udhai, 'white ant'. In 1047/1637 he built in Ahmadabad an extensive caravanserai and qaisariyya (market) (this is often referred to as his 'palace', but was not in fact his residence) adjacent to the entrance to the citadel (the massive round towers flanking the citadel gates are also attributed to him). The caravanserai has a fine eastern gateway leading to a large court, some 47 by $44 \mathrm{~m}$., with two storeys of open-fronted rooms on three sides for the accommodation of travellers; a Persian wheel within the courtyard brought water from the river for the travellers' needs. The entrance gate, $5.5 \mathrm{~m}$. high, has a great central arch occupying half the frontage, leading to an open half-dome; a smaller arch at the rear of that dome leads to an octagonal hall within, where there was a projecting gallery with a low balcony, with cut-stone screens, in front of it. The central arch of the façade is flanked by walls carrying a covered balcony supported on heavy brackets in the upper part of each side, with a blind arch below, and the whole entrance, set forward of the face of the whole building, has its sides chamfered off to produce an octagonal shape. The result is that the whole gateway looks as though it could have come from a Mughal palace in North India - very similar, in fact, to that of the so-called Jahāngīri Mahall in Agra Fort. In one corner of the building is a tahkhanna (basement) chamber with an ornamental cistern and fountain. This may have been supplied by the underground water-system mentioned above as supplying the Maidān-i Shāh. The interior arrangements of the caravanserai were much modified in the British period, after 1817, when the building was converted into the central jail.

Of a totally different style are the mosque and tomb of Nawwāb Sardar Khān, in the Jamālpur quarter of the walled city. He was a court noble of the time of Aurangzīb who had earned the emperor's gratitude by refusing to admit the unfortunate Prince Dārā Shukoh into Ahmadabad in 1070/1659; he was later for 20 years governor of Saurashtra, where he laid out his beautiful Sardār Bāgh in Junagadh where there is an exactly similar mosque. He was finally sent to Thatta in Sindh, where he died in 1095/1685; his body was brought back to 
lie in the tomb he had built himself, which formerly bore an inscription dating it to 1684 . Tomb and mosque lay within a high walled enclosure with a high gateway, but are now closely surrounded by habitation. The mosque, built of brick covered with lime-plaster, is of three arched bays, with two pseudo-minarets at the ends (they are solid, with no means of access to the mosque roof), and the prayer chamber is surmounted by three domes of a somewhat exaggerated onion shape, capped by heavy finials above a ring of foliation. The tops of the pseudo-minarets are similarly treated, with even heavier foliations, and the whole building looks top-heavy. The tomb is in much the same style, even more open to the charge of top-heaviness by having its large central onion-shaped dome surrounded by eight smaller ones of similar shape. Even the high gateway has two chhatris on top, with slender pillars but similar domes. The tomb is of the common Gujarati plan of two concentric squares, the inner one filled with fine geometrical screens which do something to relieve the mediocrity of the group as a whole.

More pleasing to the eye are the mosque and tomb of Shuja'at Khān, viceroy, 1096-1113/1685-1701, where the mosque carries an inscription of 1006/1695-6 (the date of completion, as Shuja'at Khān died in 1113/1701). Here the five-bayed façade of the mosque has the bases carrying the pseudo-minarets between bays one and two, four and five, rather than at the ends, the prayer chamber has three shallow domes, only slightly bulbous, resembling those over the tombs of Atga Khān in Delhi, with a polychrome band of merlon shapes on the drum below the swelling of the dome, and the wide piers flanking the central arch bear small blind cusped arches; the walls were of marble below and finely polished chunam above, and the floor of white and yellow marble in the pattern of musallās, or compartments resembling prayermats for individual worshippers. The tomb, on an adjacent platform, is a square structure with an arcade around the tomb chamber, without the characteristic Gujarati screens, covered with a similar dome. The mosque (in a courtyard surrounded by arcuate rooms which once formed a madrasa) of Hidāyat Bakhsh, c. 1110/1699, is again of five bays, separated only be slender piers, more modest pseudo-minarets at the ends of the façade, and with three shallow domes, a felicitous composition. The former madrasa has been so distorted by later settlement that its original plan is obscure.

An even more extraneous element is seen in a couple of late 18thcentury tombs near the tomb of Daryā Khān (there are a few more elsewhere in the city). These are square structures with the roof cornices 
curve downwards at every corner of the building, so that each façade presents an arched face. This is the Bengali chau-chalā roof, introduced into North India only in Shāhjahān's reign and taken over subsequently into Mughal building, whence it was largely copied in Rajasthan palaces and Sikh buildings; but the style - with such marvellous exemplars from the high dates of the Gujarat Sultanate in the architectural history of the region - seems singularly inappropriate here.

\section{BHAROCH*}

Name of the principal town of a district of the same name in Gujarat. It is first known as a town within the Maurya dominions, and later (c. 150 A.D.) to have been in the hands of Parthian Săhas; from the Middle Indian form bharugaccha - of the Sanskrit bhrguksetra - it was known to the Greeks as $\beta \alpha \rho v \gamma \alpha \zeta \alpha$, a seaport from which the Red Sea commerce carried on (Ptolmey, Geog. VII, i, 63; VIII, xxvi, 12), and as the head of an important trade-route into India (Periplus, 47-8). Held by Rājputs and Gurjaras, probably as tributaries of the Chālukyas, it suffered Arab invasions in 15/636, 99/717, and 154/770. It was held by Rāshtrakuțas in the 9th and 10th centuries until reconquered by the Chālukyas; from them it was taken in 698/1298 by Ulugh Khān, brother of the Sulțān 'Alā' al-Dīn Khaljī, by whom Hindu and Jain temples were destroyed (Briggs, Ferishta, i, 327). It was under a succession of Muslim governors representing the Delhi sultāns until 798/1396, when Muhammad Zafar Khān (governor from 793/1391) assumed his independence. From then it continued subject to the Ahmad Shāhī kings until annexed by Akbar in 980/1572. In 1149/1736 'Abd Allāh Beg received from Nizāam al-Mulk (independent in the Deccan from $1135 / 1722$, who previously as governor of Gujarat had made Bharoch part of his private estate) the title of Nīq 'Âlam Khān, and was the founder of the line of Nawwābs of Bharoch. In 1186/1772 Bharoch was captured by the British - whence its Anglo-Indian name of Broach.

* "Bharoč," EI, I, 1193. 


\section{Monuments}

The old fortification were rebuilt by Bahādur Shāh (932-43/1526-37). In 1071/1660 they were partially razed by Aurangzīb, but rebuilt on his orders in 1097/1685 as a protection against the Marāthās. They are now in a very dilapidated condition. The Jāmi' Masjid, c. 701/1302, is of great significance in the development of Islamic architecture in Gujarat: the earliest buildings at Patan were mere adaptations of existing Hindu and Jain structures, whereas here an original and conventionally planned mosque is composed of former temple materials, the enclosure walls, of temple stones specially recut, being thus the earliest examples of independent Islamic masonry in Gujarat. The tiveran is an open colonnade, the three compartments of which are three temple mandapas reerected intact, except for the removal of the Hindu animal figures, with 48 elaborately carved pillars; the three mihrābs are intact temple niches with pointed arches added under the lintels. The liw $w \bar{a} n$ roof, with three large and ten small domes, houses elaborate coffered ceilings removed from temples; the designs of these, though Hindu, were conventional in character, and were perpetuated in later Gujarati Islamic buildings. It appears that the whole production was the work of local Hindu artisans working under the direction of Muslim overseers.

\section{BIDAR*}

The identification of Bidar with the ancient Vidarbha (Briggs's Ferishta, ii, 411) is now discounted (cf. G. Yazdani, Bidar..., Oxford 1947, 3). Bidar was included in the Chālukya kingdom of Kalyani, 10th-12th centuries, but was in the hands of the Kākatīyās of Warangal when conquered by Ulugh Khān (later Muhammad b. Tughluq) in 722/1322 (details of siege and mention of fortifications, Diyầ al-Dīn Baranī, Tả̄knh-i Fìnūz Shāhī, Bibl. Ind., 449), from whose governor it was taken after a fierce battle in 748/1347 by a Amīr-i Șadah (commander of a șadi or subdivision of approximately 100 villages; Baran̄i, 495; Rihla, Cairo ed., ii, 75), Zafar Khān. The latter, on his acceptance as first king of the Bahmanī dynasty as 'Alā' al-Dīn Ḥasan Bahman Shāh, divided his

* "Bahman̄̄s, Monuments," EI, I, 926-5; "Barīd Shāhīs, II. Monuments," EI, I, 1047-8; "Bīdar," EI, I, 1199-1201; historical section co-authored with H.K. Sherwani. 
dominion into four provinces, of which Bidar was one. The town was important strategically, and as a fortress held the seventh Bahmanī king Shams Dīn (799/1397) in internment; Muhammad II (780-99/137897) established orphanage schools in Bidar and elsewhere, $c f$. Briggs's Ferishta, ii, 349-50. An assault by the eighth king, Fīrūz Shāh, against his brother Ahmad in 825/1422 was repulsed at Bidar, leading to Ahmad's succession, shortly after which he transferred his capital to Bidar from Gulbarga (Sayyid 'Alī TTabațabā, Burhān-i Ma'āthir, Hyderabad edn., 49-50), rebuilt the fortifications and renamed it Muhammadabad; the natural position of Bidar on a healthy plateau with abundant water, and its central position in the kingdom, offered advantages not possessed by Ahsanabad-Gulbarga. Bidar was attacked in $866 / 1462$ by Sulțān Mahmmūd Khaljī of Malwa, who destroyed some of its buildings, but was repulsed with the aid of Sulțān Mahmūd Shāh of Gujarat. Bidar's heyday under the Bahmanīs was during the able ministry of Mahmūd Gāwān, c. 866-886/1462-81; but after his murder the Bahmanī power declined, to the advantage of the minister Qāsim Barīd (founder of the Barīdī dynasty) and his family. The Bahmanīs remained as puppet kings under the Barīdī ministers until at least 952/1545; Amīr Barīd was de facto ruler until 949/1542, and his son 'Alī Barīd adopted the royal title, presumably after the death of the last Bahmanī king, Kalīm Allāh (for coins in whose name, dated 952/1545, see Proc. VII All-India Oriental Conf., 740). Bidar fell to Ibrāhīm 'Ādil Shāh of Bijapur in 1028/1619, was annexed to the Mughal empire by Aurangzìb in 1066/1656, and passed to Nizāām al-Mulk Āṣaf Jāh in 1137/1724.

\section{Bahmañ̄ Monuments}

The city and fort are both fully walled, and in their present area date from the time of Ahmad Shāh Walī Bahmanī, who incorporated the old Hindu fort in the west of the present area into his buildings of 832-5/1429-32; Persian and Turkish engineers and architects are known to have been employed. The ground on the north and east of the perimeter falls sharply away; on the other sides the walls are within a triple moat hewn out of the laterite outcrop by local Hindu masons (Yazdani, op. cit., p. 29). Much of the defences was destroyed in Maḥmūd Khalj̄̄’s invasion and restored by Niẓām Shāh; but their character was changed in the time of Muhammad Shāh Bahmanī, c. 875/1470, after the introduction of gunpowder. Minor improvements were made by Mạ̣mūd Shāh (inscriptions, EIM 1925-6, 17-8), and 
more extensive ones, including the mounting of large guns, by 'Alī Barīd Shāh, 949-87/1542-79. The description of the defences in the reign of Shāhjahān by Muḥammad Șālị̣ Kambō ('Amal-i Șālih, Bibl. Ind. iii, 249-50) indicates that little subsequent changes were made. In the perimeter of $4 \mathrm{~km}$. there are 37 bastions, mostly massive, many with gun emplacements, and seven gates as well as the three successive gates between town and fort. The first gateway serves as a barbican for the second, the Sharza Darwāza - so called from the figures of two tigers carved on the façade, a common feature of Deccan forts (Yazdani, op. cit., 32). The third gate, Gunbad Darwāza, is massive, with battered walls, hemispherical dome and corner guldastas recalling the contemporary Delhi architecture, but with an outer arch of wide span stilted above the haunch, the shape of much Persian-inspired architecture in the Deccan and characteristic of the Bahmani buildings in particular (Yazdani, op. cit., 34). The town walls are said to be the work of 'Alī Barīd (Muḥammad Sultān, Ā ̀̀na-i Bìdar, 17-18) in 962-5/1555-8, but doubtless superseded Bahmanī work. Again there are 37 bastions, adapted for long-range guns, and five gateways (Yazdani, op. cit., 83-90).

Within the fort are the Solah Khambā ('sixteen pillar', so called from a period of its decay when sixteen pillars were screened off in the $\bar{\imath}(\bar{a} \bar{a})$ Masjid, the earliest Muslim building at Bidar and the original Jāmi` Masjid, having been established before the transfer of the capital (inscription giving date 827/1423-4, EIM, 1931-2, 26-7); the style is heavy and monotonous, particularly in the $91 \mathrm{~m}$. long façade, and the inner circular piers are over-massive; the central dome rests on a hexadecagonal collar pierced with traceried windows, to form a clerestory (Yazdani, op. cit., 54-6); the Takht Mahall, the modern name for what was probably Aḥmad Shāh Walī Bahmanī’s palace described in the Burhān-i Ma'äthir, 70-1, and referred to as dār al-Imāra by Firishta, i, 627. The arches have the typical Bahmani stilt at the apex, and the fine encaustic tile-work, probably imported from Kashan, includes the emblem of the tiger and rising sun (Yazdani, op. cit., 66-77); the Bahmanī Dīwān-ī 'Āmm, with fine tile-work in floral, geometric and calligraphic (Kūfic) designs, generally Persian with some chinoiserie (Yazdani, op. cit., 62-6); the Gagan = [Skt. 'sky'], Tarkash and Rangīn Mahalls, all begun in Bahmanī times and rebuilt by the Barīd Shāhīs: typical Barīdī chain-and-pendant motif in Tarkash Mahall, 'Alī Barīd's rebuilding of Rangīn Mahall with inlay mother-of-pearl work and woodcarving in Hindu as well as Muslim patterns, with some cusping of wooden arches, the best of Barīdī work but on too small a scale to be fully 
effective (Yazdani, op. cit., 60-2, 57-9, 44-9 respectively); a group of underground rooms, Hazār Kotthrī, with an emergency escape passage leading outside the walls (Yazdani, op. cit., 77-8); the Shāhī Hammām, late Bahmanī or early Barīdī, with a fine vaulted ceiling (Yazdani, op. cit., 51-2); and minor buildings.

Within the town walls are the Chaubāra, a massive tower at a crossroads probably built by Aḥmad Shāh as an observation post (Yazdani, op. cit., 90); the great madrasa of Mahmūd Gāwān, built 877/1472, whose Persian prototype was the madrasa of Khargird in Khurasan $(c f$. E. Diez, Churasanische Baudenkmäler, i, 72-6); its remaining minār (the other, with the south-east corner, destroyed by a gunpowder explosion in 1107/1696), $40 \mathrm{~m}$. high, in three stages. Much of the former tilework has perished from the minārs and façades, but the proportions, the silhouette, and the interplay of light and shade due to the rows of deeply recessed arches on all faces are very pleasing to the eye. The most imposing monument of the Bahmani period, it has no parallel elsewhere in India (Yazdani, op. cit., 91-100); the Takht-i Kirmānī, a gateway containing a room in which is a couch associated with the saint Khalīl Allāh, with fine cut-plaster medallions, etc., of late Bahmanī design, and a trefoil parapet which, originating in the Bahman̄ period, is found in Barīdì buildings also (Yazdani, op. cit., 100-2); the Jāmi' Masjid of the city, plain but elegant, with a high lantern-vaulted lìwān under its double dome, late Bahmanī work restored in the Barīdī period (chain-and-pendant motif in spandrels of façade; Yazdani, op. cit., 103-4); the Bari Khānqāh of Maḥbūb Subḥānī, whose mosque parapet shows the overlapping arches of the Bahmani period (Yazdani, op. cit., 111). Outside the town walls are (besides the tomb buildings of the Bahman̄̄s and Barīd Shāhīs) the fine Chaukhandī of Hazrat Khalìl Allāh, similar in style to the tomb of 'Alä' al-Dīn Bahmanī and one of the best Bahmanī buildings (Yazdani, op. cit., 141-6); the tombs of the Abyssinian nobles in the Habshī Kōt (Yazdani, op. cit. 180); the Kālī ('black') Māsjid, probably early Barīdī, whose mihrāa, projecting out from the liwa an, forms a high square chimney-like base for a dome supported on each side by an open arch, resembling an aerial Barīdī tomb (Yazdani, op. cit., 196-7); and numerous other buildings.

The Bahmanī tombs at Ashtur, $2.5 \mathrm{~km}$. east of the town, are on a large scale, with lofty and sometimes bulbous domes. None of these has battered walls, and none is double, as at Gulbarga. The finest tomb, that of Ahmad Shāh Walī (d. 839/1436), shows the characteristic later Bahmanī arch, stilted above the haunch, and is of great importance 
on account of its superb calligraphic decoration which includes two shajrās of the saint Ni'mat Allāh al-Kirmānī. That of 'Alā' al-Dīn II (d. 862/1458) has striking encaustic tile-work and, unusually, some arches struck from four centres. That of Mahmūd (d. 924/1518) has its walls decorated with arched niches one above the other, more characteristic of post-Bahmanī architecture.

\section{Barìd̄̄ Monuments}

As successors to the well established Bahmanī dynasty the Barīd Shāhīs inherited many fine structures, and their building activity in Bidar was more a matter of adaption and rebuilding than of the erection of any major stuctures. The progress of the Barīdī style is well illustrated in their tombs, which form a royal necropolis some $3 \mathrm{~km}$. west of the city walls, and occupy a large area on account of the vast garden enclosures of each tomb.

The tomb of Qāsim I (d. 910/1504) is a small insignificant building with a plain cubical dome (Yazdani, op. cit., 149). That of his successor, Amīr Barīd I, was left incomplete on his sudden death in 959/1542 without a dome; there are two storeys of arches on each façade, pierced by a central arch running through both storeys, all stilted at the apex as in the earlier Bahmanī buildings. The reign of 'Alī Barīd (949-87/1542-79) saw much building activity; large scale improvements in fort and city fortications, including the mounting of many more large guns; rebuilding the Rangīn Mahal, with fine mother-of-pearl inlay work and intricate wood-carving to which Hindu patterns are mixed with Muslim designs (Yazdani, op. cit., 44-9); much alteration of the Tarkash Mahall, especially the upper storey, in which the chain-and-pendant motif, characteristic of Barīdī work from now on, is apparent (Yazdani, op. cit., 57-9); and tomb of 'Alī (d. 987/1579), very well sited, with an imposing gateway having wide arches with low imposts and upper rooms decorated with a profusion of small cusped niches. Each wall of the tomb consists of one open arch, through which the fine sarcophagus of polished black basalt is visible; the interior is thus very bright and airy, and is embellished with good encaustic tile work (verses from 'Atțāar, Qur'ānic texts, in thulth), though not over-elaborated. Since the tomb is open on all sides there is no qibla enclosure, and attached to the tomb there is a separate mosque with slender minarets, a vaulted ceiling, and fine cutplaster decoration on the façade. Tomb, gateway and mosque have the trefoil parapet which originates in the late Bahmanī period (Yazdani, 
op. cit., 151-60). The tomb of Ibrahīm (d. 994/1586) imitates that of his father on a smaller scale but is incomplete and presents surfaces of lime-laid masonry. Carved corner jambs show the Hindu chakra as part of their decoration (Yazdani, op. cit., 160-1). Both these tombs have a large dome, not stilted but recurved at the base to form a three-quarter orb, which appears somewhat top-heavy for the structure. The constriction of the dome is characteristic of the contemporary buildings of the Qutb Shāhī and 'Ādil Shāhī dynasties of Golkonda and Bijapur also. The single opening is reverted to in the tomb of Qãsim II, which is better proportioned, but the open design is apparent in the dome over the mihrāb of the Kālī ('black') Masjid (Yazdani, op. cit., 196-7). The Jāmi 'Masjid of the town, a late Bahmanī building, was restored during the Barīdī period (chain-and-pendant motif in spandrels of the façade) (Yazdani, op. cit., 103-4).

From the time of 'Alī Barīd the buildings become more ornate in their minor detail, and the influence of the Hindu mason becomes more apparent; in some Barīdī buildings - e.g., the Kālī Masjid - the forms used in stone often seem more appropriate to wood-work. Much of the later work shows that meretricious character often apparent in the buildings of a dynasty in decline.

\section{BIHAR*}

A province of India, bounded by Uttar Pradesh on the west, Nepal on the north, West Bengal on the east and Orissa on the south, taking its name from the now unimportant town of Bihar, surrounded by Buddhist monasteries (Skt. vihâra). Bihar was in the British period from 1765 within the Lieutenant-Governorship of Bengal, later joined administratively with the now independent Orissa. This lack of independence reflects the position of the region from the earliest days of Islamic supremacy in India, and its history is one of individual governors and towns rather than of dynasties and regions. Monghyr (Mungīr), for example, was taken during Ikhtiyār al-Dīn Muhammad b. Bakhtiyār Khaljī's raids on Bihar in 589/1193 and held by him under the Delhi sultạn Quṭb al-Dīn Aybak; it was annexed to Delhi by Muhammad b. Tughluq in 730/1330, belonged to Jaunpur from 799/1397, reverted to

\footnotetext{
* "Bihār," EI, I, 1209-10.
} 
Delhi when overrun by Sikandar Lōdī in 893/1488, and was later held by the kings of Bengal before becoming subject to the Mughals. Parts of Bihar did form a separate administrative unit in the 13th century (Shams Dīn Iletmish established a governor in Bihar in 622/1225); under Akbar in 990/1582 it formed a sūba or eight sarkārs, subordinate to the süba of Bengal. The capital remained at the town of Bihar until transferred to Patna by Shēr Shāh Sūrī in the early 16th century. The importance of the region was as a buffer between Awadh and Bengal until the Mughal period, when the emphasis was as a line of communication between them, as many fine bridges of the Mughal viceroys testify.

\section{Monuments}

There is no particular 'Bihari' style of Indo-Islamic architecture. The finest group of buildings is at Sasaram, including the justly famous mausoleum of Shēr Shāh (inscription of 952/1545) standing $50 \mathrm{~m}$. high in a large artificial lake; its architect, Aliwāl Khān, had been a master-builder under the Delhi Lōdīs, but his treatment of the octagonal mausoleum transcends any of the Lōdī conceptions. Shēr Shāh obtained the fort of Rohtasgarh from its Hindu rāja in 946/1539, and to him is attributed the Jāmi 'Masjid; the reconstructed fortifications, the palaces, Habash Khān's tomb and mosque, etc., date from the viceregency (988-1008/1580-1600) of Rājā Mān Singh under Akbar; to Mān Singh is attributed the mosque at Hadaf, near Rajmahal; the long barrel-vault traversing the central bay of the tiw wan of this early Muhgal structure recalls the style of Jaunpur. Monghyr has been mentioned above: the fort is reputed to have been built by early Bengal kings, but the style appears Mughal; Rājā Todar Mall is known to have repaired the fortifications in 988/1580. The two forts of Palamav, built by local Chero Rājās in the 17th century, were taken by the Mughal governor Dāūd Khān Kurayshī, who erected a mosque (1070/1660) and other structures; the Nayā Qil'a boasts the splendid Nāgpurī Darwāza in the Jahāngīiñ style. The tomb of Makhdūm Shāh Daulat (Chōtī Dargāh) at Maner erected by the governor Ibrāhīm Khān in 1017-26/1608-16 is of some merit. For other buildings see M.H. Quraishi, List of ancient monuments... in Bihar and Orissa, ASI NS, ii, Calcutta 1931. 


\section{BIJAPUR*}

\section{History}

Town and headquarters of the district of the same name in northern Karnataka. It was the seat of the Yādavā kings for over a century from $586 / 1190$ to 694/1294 when it was conquered by 'Alā' al-Dīn Khaljī for his uncle Jalāl al-Dīn Khaljī, king of Delhi. In 890/1485-6 Yūsuf, an alleged son of the Ottoman sultān, Murād II who, on the accession of his brother Mehmed II to the throne, was said to have escaped certain death through a stratagem of his mother, founded the Muslim kingdom of Bijapur and built the citadel. This story seems to be unknown to the Ottoman historians (cf. Khalil Edhem, Düwel-i Islämiyye, 495); the Ottoman historian Munajjim Bashi, who includes an account of the 'Ádil Shāhīs in his fāmi al-Duwal, describes Yūsuf as of Turcoman origin. For a discussion of this question see further Ismail Hikmet Ertaylan, Adilsâhîler, Istanbul 1953, 3 ff.). He also captured Goa and included it in his dominions. He assumed the title of 'Âdil Shāh which became the royal surname and the dynasty came to be known as the 'Ádil Shāhīs of Bijapur. He was succeeded by three incapable or profligate rulers. In 965/1557 'Alī 'Ádil Shāh came to the throne; he built the city wall of Bijapur, the Jāmi' Masjid, aqueducts and other public utility works. In 973/1565 the combined troops of Bijapur, Ahmadnagar and Golkonda defeated the Vijayanagara forces at the so-called battle of Talikota. 'Alī 'Ādil Shāh died in 987/1579 and was succeeded by his minor nephew Ibrāhīm 'Âdil Shāh, under the regency of the famous Chand Bībī. He died in 1036/1626 after an independent rule of 47 years and was succeeded by Muhammad 'Ādil Shāh, during whose reign, Shivājī, the Marāthā leader rose to power. His father Shāhjī Bhōnslē was a petty officer of the Bijapur sultān. Having been bred and brought up on Bijapur 'salt', Shivājī repaid the debt of gratitude by attacking Bijapur territory and between 1056/1646 and 1058/1648 he seized many forts of importance. In 1067/1656-7 Aurangzīb, while still a prince, attacked and beseiged Bijapur but on hearing of the serious illness of Shāhjahān had to lift the siege and leave for Agra. Thirty years later (1097/1686) Aurangzīb succeeded in subduing Bijapur during the reign

* "Bīdjāpur" EI, I, 1203-4; history section co-authored with A.S. Bazmee Ansari. 
of Sikandar 'Adīl Shāh (1083/1672-1097/1686), the last of the 'Adīl Shāhs. Sikandar 'Ādil Shāh was imprisoned and allowed a pension by Aurangzīb. He died in 1111/1699-1700. In 1100/1688 Bijapur was visited by a virulent type of bubonic plague which claimed 150,000 persons, including Aurangābādī Maḥall, a queen of Aurangzīb, while Ghāzì Dīn Fìrūz Jang, a high noble, lost an eye. Towards the close of his reign Aurangzīb appointed his youngest son, Kām Bakhsh, to the government of Bijapur. On Aurangzīb's death Kām Bakhsh proclaimed himself emperor at Bijapur, assuming the title of Din-Panāh. In 1137/1724 Bijapur was included in the dominions of the Nizām of Hyderabad. It was, however, transferred to the Marāthās in 1174/1760 for a sum of 6,000,000 rupees. On the overthrow of the Pēshwā in 1234/1818 the British occupied Bijapur and assigned it to the Rājā of Satara in whose possession it remained till 1266/1848 when, on the lapse of the State, it formed part of British Indian territory. In 1281/1864 Bijapur was made a separate district and in many of the old palaces were housed government offices which were, however, later shifted elsewhere.

The 'Ādil Shāhīs were great patrons of art and literature. Malik Qummī, the poet, and Zuhūri, the celebrated author of the two Persian classics, Sih Nathr and Min̄a Bazār, adorned for a considerable time the court of Ibrāhīm 'Ādil Shāh, himself a poet, who composed in Dakhnī Urdu.

\section{Monuments}

The 'Âdil Shāhīs developed the building art above all others, and their architecture is the most satisfactory of all the Deccan styles, both structurally and aesthetically; hence their capital Bijapur shows a more profuse display of excellent and significant buildings than any other city in India except Delhi alone. The Bijapur style is coherent within itself, and there is a gradual progression between its two main phases. Most worthy of note are the doming system with its striking treatment of pendentives; profuse employment of minarets and guldastas as ornamental features, especially in the earlier phase; elaborate cornices; reliance on mortar of great strength and durability. The materials employed are either rubble-and-plaster or masonry; the stone used in masonry work is a local, very brittle trap. There is evidence to show that architects were imported from North India, and that use was freely made of local Hindu craftsmanship. 
Pre-'Ádil Shāhī works are few: the rough mīnārs with wooden galleries in the walling of the Makka Masjid; Karīm al-Dīn's mosque, inscr. 720/1320, from pillars of old Hindu temples, trabeate, with elevated central portion as clerestory, recalling the mosques of Gujarat; the Bahmanī Wāzīr Khwāja Jahān's mosque, c. 890/1485, similar but without clerestory.

No 'Ādil Shāhī building can be certainly assigned to the reign of Yūsuf. The earliest dated structure, referred to as Yūsuf's Jāmi' Masjid, strikingly foreshadows the style to come with single hemispherical dome on tall circular drum with the base surrounded by a ring of vertical foliations so that the whole dome resembles a bud surrounded by petals, and façade arches struck from two centres, the curves stopping some way from the crown and continued to the apex by tangents to the curve; an inscription of 918/1512-3 records its erection by Khwāja Sanbal in the reign of Sulțān Mạ̣mūd Shāh, son of Muhammad Shāh Bahman̄i, indicating that Bahmanī suzerainty was still acknowledged some time after the 'Ādil Shāhī defection. Of Ibrāhīm's reign are also the massive Dakhnī '̄ Igāh (within the present city walls) and several small mosques, on one of which (Īkhlāṣ Khān's) the arch spandrels are filled with medallions supported by a bracket-shaped device, later a very common ornament. Only one mosque of this period (at Ibrāhīmpur, $932 / 1526)$ is domed.

The long reign of 'Alī I saw much building activity: the city walls, uneven in quality since each noble was responsible for a section, completed 973/1565, with five main gates flanked by bastions and machicolated, approached by drawbridges across a moat, beyond which is a revetted counterscarp and covert way (many bastions modified to take heavy guns; inscriptions of Muhammad and 'Alī II); the Gagan ('sky') Mahall, an assembly hall with much work in carved wood; a mosque in memory of sayyid 'Alī Shāhīd Pīr, small (10.8 m. square) but superbly decorated with cut-plaster, with a steep wagon-vaulted roof parallel to the façade, a tall narrow chimney-like vault over the mihräb which has a door leading outside; the Shāhpur suburb; outside Bijapur, the forts of Shahdrug (966/1558), Dharwar (975/1567), Shahanur and Bankapur (981/1573); 'Alī's own severely plain tomb; and his Jāmic Masjid, generally ascribed to $985 / 1576$, a fine large (137.2 by $82.3 \mathrm{~m}$.) building, not fully completed (only buttresses where tall minārs were to be added, no kanguras over façade), sparingly ornamented (only the central arch of seven in the tiw wan façade is cusped and decorated with medallion-and-bracket spandrels), with the great hemispherical dome, 
standing on a square triforium, capped by the crescent, a symbol used by the 'Âdil Shāhīs alone among the Deccani dynasties. The cornice is an improvement on earlier works by showing deeper brackets over each pier instead of a row of uniform size. The vaulting system of the dome depends on cross-arching: two intersecting squares of arches run across the hall between the piers under the dome, meeting to form an octagonal space over which the dome rests; the pendentives thus overhang the hall and counteract any side-thrust of the dome. The exterior walls are relieved by a ground-floor course of blind arches over which is a loggia of open arches.

In Ibrāhīm II's reign fine sculptured stonework replaces the earlier rubble-and-plaster. The palace complex dates from about 990/1582 (Sāt Manzil, 'Granary', Chīnī Mahall); the first building in eleborate sculptured stone is Malika Jahān's mosque (994/1586-7), which introduces a new shape by the dome forming three quarters of a sphere above its band of foliation. The Bukhārī mosque and three others on the Shāhpur suburb are very similar, and fine stonework occurs also in perhaps the greatest work of the 'Ādil Shāhīs, the mausoleum of Ibrāhīm II and his family known as the Ibrāhīm Rauza: within a garden enclosure $137.2 \mathrm{~m}$. square stand a tomb and mosque on a common plinth; the tomb (shown by inscriptions to have been intended for the queen Tāj Sultāna only) has uneven spacing of the columns and other features, and the cenotaph chamber is covered with geometric and calligraphic designs, reputedly the entire text of the Qur'ann. The mosque columns are regular. The whole composition is in perfect balance and was minutely planned before building. An inscription gives the date of completion, by abjad, as 1036/1626. Palaces of this reign include the Ānand Mahall, built for entertainments (Basātīn al-Salāțin), and the Āthār Mahall (1000/1591) with fine painted wood decoration including some fresco figure-paintings thought to be the work of Italian artists. The Andā ('egg') Masjid, 1017/1608, has the mosque (presumably for the use of women) on the upper storey, with a sarā $\imath$ below; the masonry is polished and finely jointed, and above is a ribbed dome. In 1008/1599 Ibrāhīm proposed moving his seat of government some $5 \mathrm{~km}$. west of Bijapur where the water supply was better; but the new town, Nauraspur, was sacked in 1034/1624, before its completion, by Malik 'Ambar, and little remains. Other work includes the mosque known as the Nau Gunbad, the only Bijapur building with multiple doming; the fine but incomplete mausoleum of the brother pìrs Hamīd and Lațif Allāh Kāàirī (ob. 1011/1602, 1021/1612); and, the supreme example 
of the later work of this reign, the Mihtar-i Mahall, really a gateway to the inner courtyard of a mosque in the city, with a narrow façade based on a vertical double square, richly covered with stone diaper patterns and with a balcony supported by long struts of carved stone, their decoration resembling, and really more appropriate to, woodwork patterns; fine panelled ceilings within; superb cornices and elaborate minārs, outside, all richly carved.

Works of Muhammad's reign are of uncertain chronology owing to lack of inscriptions and historical records. Muṣafā Khān's mosque is plain with a façade in which the central arch is much wider than the flanking ones, following the pattern of many of the older palaces; his sarā $\bar{\imath}$ (insc. 1050/1640-1); a mahall at Aynapur; tombs of the wazir Nawāz Khān (ob. 1058/1647) and of several pìrs showing a decadence in style with a second storey and dome too attenuated for the size of the buildings; Afẓal Khān's mausoleum and mosque, where the second storey is of insufficient height - the mosque being the only two-storeyed one in Bijapur, the upper tiwe $\bar{a} n$ being the duplicate of the lower except for the absence of a minbar, hence presumably for Afẓal Khān's zanāna, 63 members of which have their reputed graves $1 \mathrm{~km}$. to the south: inscription in mausoleum 1064/1653; and the major building work, one of the supreme structural triumphs of Muslim building anywhere, Muhammad's own mausoleum, the Gol Gunbad. The tomb building, standing within a mausoleum complex, is formally simple: a hemispherical dome, of $43.9 \mathrm{~m}$. external diameter, is supported on an almost cubical mass $47.4 \mathrm{~m}$. square (external), with a staged octagonal turret at each angle. The floor area covered, about 1,693 sq. m., is the largest in the world covered by a single dome. External decoration is simple, confined to the great cornice $3.5 \mathrm{~m}$. wide supported by four courses of brackets, the openings on the pagoda-like corner turrets, and the merlons and minarrs of the skyline. The dome is supported internally by arches in intersecting squares as in the Jāmi 'Masjid; inscription over the south door gives the date of Muhammad's death by abjad as $1067 / 1656$ at which time work on the building presumably stopped, the plastering being incomplete. Unfinished also is the tomb of his queen Jahān Bēgam at Aynapur: foundations, piers and octagon turrets to the identical scale of the Gol Gunbad, but the dome was intended to be carried across a central chamber.

Of 'Alī II's reign: the pavilion called Pānī Mahall on the citadel wall, and the Makka Masjid, both with fine masonry and exquisite surface carving; the tomb-complex of Yāqūt Dābulī, unusual by having the 
mosque larger than the tomb; and 'Alì's own unfinished mausoleum, with arches struck from four centres instead of the usual Bijapur arch. Later buildings are insignificant, except for Aurangzīb's eastern gate to the Jāmi' Masjid; the tomb of the last monarch, the minor Sikandar, closes the 'Âdil Shāhī effort with a simple grave in the open air.

\section{Champaner*}

A ruined city of Gujarat in Western India, about $125 \mathrm{~km}$. south-east of Ahmadabad, taken by the Gujarat sulțān Mahmūd Shāh I 'Begrā' on his conquest (889/1484) of the adjoining stronghold of Pawagarh, which had successfully resisted Ahmad Shāh I in 821/1418. The 'Begrā' occupied Champaner forthwith, building a city wall with bastions and gates (called Jahānpanāh; inscription EIM 1929-30, 4-5), and a citadel (bhädar). He renamed the city Mahmudabad, and it was his favourite residence until his death in 917/1511; it remained the political capital of Gujarat until the death of Bahādur Shāh in 942/1536. When Gujarat came under the Mughals after 980/1572 Champaner was the head of a sarkār of 9 mahals (Jarrett, $\bar{A} i n$-i Akbarī, ii, 256; of 13 divisions, according to the Mir'ät-i Sikandarì); it fell to the Marāthās at the end of the 18th century, and came into British hands in 1853; almost deserted, it was not recolonized.

\section{Monuments}

Of Maḥmūd's seven-storeyed palace (Sāt Manzil) built in steps on the cliff edge opposite Pawagarh only the lowest storey remains; the other monuments other than the walls ( $c$. Bombay Gazetteer, iii, 307-8) are all mosques and tombs, which in their similarity exhibit a local style. The Jāmi 'Masjid, c. 929/1523, is inspired in plan by that of Ahmadabad, 100 years older; but here there is a double clerestory in the liw $w \bar{a}$ in the space of one dome only; the arcuate maqșura screen and the trabeate hypostyle liwe arn are well integrated; the side wings of the līwān are proportioned as a double square ( 8.5 by $17.0 \mathrm{~m}$.); a zanāna enclosure is formed by screening off the northernmost mihra $\bar{b}$; and the external surfaces, as in all the Champaner buildings, are the subject

* “Čāmpānēr," EI, II, 10-11. 
of rich plastic decoration - particularly the buttresses supporting each of the seven sumptuous mihräbs. The other buildings - ten mosques, many nameless tombs - are of similar style, characterized by refinement of decoration; the niches in the minārs of the Nagīnā Masjid are of an exquisite marble tracery excelled only by that of Sidī Sa î̀d's mosque in Ahmadabad. The tombs use the arch more freely than the mosques, and their carved decoration is of consummate delicacy, skill and craftsmanship.

\section{ChANDERI*}

A town and old fort in north-central India, on a tableland overlooking the Betwa valley on the east. Early references by al-Bīrūnī (421/1030) and Ibn Bațtutata do not mention the fort and probably relate to a site some $15 \mathrm{~km}$. north-north-west known now as Burhi [Urdū, 'old'] Chanderi; here there are ruined Islamic fortifications among Hindu and Jain remains, probably of the early 14th century, for although the city fell in 649/1251 to Ghiyāth al-Dīn Balban, then $n \bar{a}$ ì of Nāṣir al-Dīn, whose aim was the seizure of booty and captives, it did not come into Muslim hands until 'Ayn al-Mulk's defeat of the Rājā Harānand in 705/1305. Four years later it formed the rendezvous for Malik Kāfūr's force before his march on Warangal in Telingana. New Chanderi seems to have been built by the Ghūrī kings of Malwa in the early 15th century (inscriptions of Dilāwar Khān and Hūshang, in ASI AR, 1928-9, 128, and EIM 1943, 47), from whom it was wrested in the Malwa interramal struggles by 'Alā' al-Dīn Shāh Khaljī I in 842/1438 (Bayley's History of Gujarat [Ta'rikh-i Alfi], 123), and remained under the Khaljīs' governors until the vacillating governor Bahjat Khān revolted, supporting against Mạ̣mūd II his brother Șạhib Khān, the puppet Muhammad II, and appealing to Sikandar Lōdī of Dehli for support in 919/1513. Hereafter Chanderi's position on the borders of Bundelkhand and Malwa led to its changing hands frequently: Sikandar's forces remained in occupation until 921/1515, but after their withdrawal it was seized by the Rānā of Chittaur who set up Medin̄̄ Rāy, Mahmmūd II's dismissed minister who had escaped the massacre at Mandu, as governor; from him it was taken by Bābur in 934/1528,

\footnotetext{
* “Čandērī," EI, II, 12-13.
} 
who restored it to Ahmad Khān, son of Șāhib Khān. Later it fell to the Pūrbīya Rājput Pūran Mal, who lost it to Shēr Shāh c. 947/1540, but later retook it and massacred and degraded the Chanderi Muslims, an act which brought retribution from Shēr Shāh in 950/1543 (Brigg's Ferishta, ii, 160). After Akbar had gained the süba of Malwa, Chanderi became the headquarters of a sarkār ( $\bar{A} \hat{\imath} n-i$ Akbari, i, 122), when it was said to have been a large city with 14,000 stone houses and over 1,200 mosques. Thereafter it passed frequently into Bundel hands, and after the early 18th century remained in Hindu possession.

\section{Monuments}

The city is walled, with five gates, one of which is the Kātīghātī hewn through the rock outcrop; the fort, which stands some $70 \mathrm{~m}$. higher, is dependent for its water supply on a large tank at the foot of the hill, access to which is by a covered way (map in Cunningham, ASI, ii, Pl. XCIII). The Jāmi' Masjid is similar to that of Mandu with its tall domes over the tiw wan stilted between springing and haunch, but with the cornice supported by a row of serpentine brackets, a contribution of Gujarat workmen; two tombs known as the madrasa and the Shāhzādī kā Rauza are of excellent workmanship in a similar style; probably somewhat earlier is the Kūshk Mahall, a large square building with intersecting passages on each of the remaining four storeys which divide the interior into four quadrants, in the suburb of Fatehabad, $3 \mathrm{~km}$. west, identified with the seven-storeyed palace (sāt manzil) whose building was ordered by Mạ̣mūd Shāh I in 849/1445. At the western foot of the fort is an unattached gateway, the Bādal Mahall Darwāza, a triumphal arch between two tapering buttresses, somewhat over ornamented.

\section{Daulatabad*}

\section{History}

This hill fort, $16 \mathrm{~km}$. north-west of Aurangabad in Maharashtra State, was called Deogiri (properly Devagiri), 'Hill of God', in pre-Muslim times as the capital of the Yādavas, originally feudatories of the Chālukyas

\footnotetext{
* "Dawlatābād," EI, II, 179-80; history section co-authored with H.K. Sherwani.
} 
but independent since 1183 A.D., after which they continued to rule the territory from Deogiri independently. 'Alā' al-Dīn, nephew of Sulțān Jalāl Dīn Fīrūz Khaljī of Delhi, actuated by reports of the immense wealth of Deogiri, reached there by forced marches in 693/1294 and invested the fortress. Rāmchandra, the then $r \bar{a} j \bar{a}$, taken by surprise, was ultimately forced to surrender to the invaders huge quantities of gold, silver and precious stones, which became 'Alā' al-Dīn's bait to lure Fìrūz to his death, as well as agree to the cession of Elichpur to the Delhi empire. Rāmchandra failed to remit the revenues of Elichpur and in 706/1307 a force commanded by Kāfūr Hazārdīnārī, then Malik Nā̀ib, was sent against him; but on making his submission to Kāfūr he was courteously sent to the capital where he offered sumptuous gifts in lieu of tribute. His ready pardon and official appointment as governor of Deogiri, with the title of Rāy-i Rāyan, has been attributed to 'Alā alDīn's superstitious regard for Deogiri as the talisman of his wealth and power. But his son and successor, Shankara, defied the Delhi hegemony, and Kāfür was again sent south in 713/1313, where he assumed the government of the state having put Shankara to death. Shankara's sonin-law Harapāla proclaimed his independence some three years later, and the new Delhi sulțān, Quṭb al-Dīn Mubārak Khaljī, personally led an expedition south, slew Harapāla, re-annexed the Deogiri lands, and built in 718/1318 the great Jāmi` Masjid there.

The next important date in the history of Deogiri was when Muhammad b. Tughluq decided in 727/1327 that, since Delhi was not sufficiently central in his dominions, Deogiri should be renamed Daulatabad and become his capital. Officials were at first encouraged to settle there, but in 729/1329 the entire population was compelled to move to Daulatabad as a punitive measure (Baran̄̄, 481 ff; Ibn Bațtūṭa, iii, $314 \mathrm{ff}$ ), and from there as a base of operations order was restored in the Deccan. But shortly thereafter Mongol raids in North India necessitated Muhammad's return to Delhi and Daulatabad reverted to its status as a southern garrison. It was at Daulatabad that Ismāîl Mukh was elected their leader by the Amīrān-i Șadah in 747/1346 and it was again there that a year later Zafar Khān, who had defeated the Delhi army, superseded Ismā̄îl and became the first Bahmanī sulțān. The Bahmanīs retained Daulatabad as a garrison on their northern frontier and improved its defences; the conspicuous Chānd Mīnār dates from their occupation. It passed to the Nīzām Shāhīs of Ahmadnagar in 905/1500, becoming their capital in 1009/1600. The Mughal emperor Shāhjahān clearly considered possession of Daulatabad to be the key 
to dominion over the Deccan, and in 1043/1633 it was taken for the Mughals by Mahābat Khān after a fierce siege ('Abd al-Hamīd Lāhawrī, Bādshāh-nāma, Bibl. Ind., 496-536). Salābat Jang secured Daulatabad for the Nizām al-Mulk in 1170/1757, but lost it three years later to the Marāthās.

Daulatabad once boasted of the Fathabad mint (for the name Fathabad given to Daulatabad in the time of Muhammad I Bahmanī, see Burhān al-Ma'äthir, 1936 ed., 17) where coin was struck from 761/1360 to $766 / 1365$; it was also the centre of a papermaking industry.

\section{Monuments}

The earliest building work at Daulatabad (apart from the rock-cut caves of the 1st century B.C.) is the scarping of Devagiri, a single conical hill of rock some $200 \mathrm{~m}$. high commanding a natural pass. This scarping, dating at least from the early Yādava times, results in the entire circuit of the rock presenting a vertical face 50 to $65 \mathrm{~m}$. high, above a water-filled moat of rectangular section dug a further $15 \mathrm{~m}$. into the rock (a causeway across the moat leading to a rock-cut shrine shows its Hindu provenance). The utilization of stone of Hindu workmanship in later Islamic building indicates the former existence of a town on the sloping ground to the east.

It is on the east that the triple apron of fortification lies, dating in origin from the time of Muhammad b. Tughluq. The outermost wall is the curtain of the outer town, which is traversed from south to north by the Aurangabad-Khuldabad road; the town (called Ambarkōt in 'Abd al-Hamīd Lāhawrī, Bādshāhnāma, passim) is an area about $2 \mathrm{~km}$. north-south by a maximum of $1 \mathrm{~km}$. east-west; the second wall encloses an area of $1.2 \mathrm{~km}$. by $0.4 \mathrm{~km}$. to the west of the first, called Katak (= Sanskrit kataka) by Ibn Bațtūța and Mahākōt (Great Fort) by Lāhaurī, and is entered through a hornwork formed by a succession of rounded bastions; a less elaborate entrance in the third apron leads to the citadel of Devagiri (Bālākōt of Lāhaurī) through a steep flight of steps, the rock-cut moat crossed by a narrow stone bridge, a tunnel through rockcut chambers and re-used Jain caves emerging some $15 \mathrm{~m}$. higher, a broad rock staircase leading to a Mughal bāradari, and finally another flight of 100 steps to the acropolis, a platform $50 \mathrm{~m}$. by $36 \mathrm{~m}$., on which guns are mounted. All three walls are defended by external ditch and counterscarp; they all show signs (by heightening in work of smaller stone) of modification during the Bahmanī period. Of interest in the 
defence works are: (1) the bridge over the final moat, with its central portion about $3 \mathrm{~m}$. below the level of each side, approached by steep flights of steps from counterscarp and gallery; the height of water in the moat must have been under control, so that the central portion of the bridge could be submerged; (2) the long tunnel, at the head of which was an iron barrier which could be rendered red-hot by lighting a fire on it (for a different interpretation see Sidney Toy, The strongholds of India, London 1957, $38 \mathrm{ff}$., criticized by J. Burton-Page in BSOAS, xxiii/3, 1960, 516 ff.); midway is a rock-cut look-out post.

The mosque of Quṭb al-Dīn Mubārak Khaljī of Delhi (inscription, 718/1318) is perhaps the earliest Muslim monument. Largely an improvization out of temple material, it has tapering fluted corner buttresses and a corbelled dome, and is some $78 \mathrm{~m}$. square in overall plan (illustration in ARADHS, 1925-6, Pl. III); the mihrāb has since been filled with an idol. The mosque has no minaret; fulfilling this function, however, is the Chānd Mīnār, $30 \mathrm{~m}$. high, of about 840/1435, similar in shape to the towers of Maḥmūd Gāwān's madrasa at Bidar, but with three galleries supported by elaborate brackets. In addition to its function as a minar of the mosque, it was also an observation post, since it commanded the dead ground on the north-east.

The palaces are mostly in ruins; noteworthy are the baradar mentioned above, built for Shāhjahān's visit in 1046/1636, and the Chīn̄ Mahall in Mahākōt, of the Niẓām Shāhī period, with fine encaustic tilework; the latter was used as a state prison for the last Quṭb Shāhī ruler, Abu'l-Hasan (Khwāfì Khān, Muntakhab al-Lubāb, ii, 371 ff.).

\section{DeLHI*}

The city of Delhi, situated on the west bank of the river Yamuna was the capital of the earliest Muslim rulers of India from 608/1211, and remained the capital of the northern dynasties (with occasional exceptions: Daulatabad, Agra, and Lahore were the centres favoured by some rulers) until the deposition of Bahādur Shāh in 1858; from 1911 it became the capital of British India, and after 1947 of Independent India.

* "Dihlī, 1. History; 2. Monuments," EI, II, 255-66. 
The usual Romanized form of the name is Delhi, based on the commonest form in the earlier Muslim usage Dihlī; the common spellings in Urdū, Hindī (certainly from the time of the Prithi Rāj Rāso of the 13th century), and Panjābī represent Dilli. The etymology is obscure; for some popular etymologies see A. Cunningham, ASI, i, $137 \mathrm{ff}$.

It has become popular to speak of "the seven cities of Delhi"; but the number of centres of government in the Delhi area has in fact been nearer double that number. The earliest settlement was Indrapat, Sanskrit Indraprastha, a tell on which the present Purānā Qil'a stands, supposed to have been built in legendary times by the Pāndavas; the site is certainly old, and potsherds of Painted Grey ware and Northern Black Polished ware, types dating back to the 5th century B.C., as well as Kushāna fragments of the 1st and 2nd centuries A.D., have been discovered there (see $\left.A I, \mathrm{x}^{-} \mathrm{xi}, 1955,140,144\right)$. The region of Delhi seems to have been almost abandoned thereafter, for the next settlement dates from the 9th or 10th century, the Tomār city now known as Sūraj Kund, where a large masonry tank and an earthwork are still in existence. More extensive are the remains of the Chauhān Rājpūt town, dating probably from the 10th century, which existed immediately prior to the Muslim conquest. On a small hill in the south-west of this region a citadel, Lālkōt, was built in c. A.D. 1052 by Ānang Pāl, and around the town an outer wall was thrown, as a defence against the Muslim invaders, by Prithvīrāja in about 576/1180 (Cunningham, (Fig. 1) $A S I$, i, 183). Subsequent to the conquest a mosque, known as Masjid Quwwat al-Islām, was erected in 588/1192 by Quṭb al-Dīn Aybak, who later commenced the building of the adjoining minār not only as a ma'dhana but also as a commemoration of his victory; for these, their extensions by Shams Dīn Iletmish and 'Alā al-Dīn Khaljī, and other buildings in this so-called "Qutb site" see Monuments, below. The systematic refortification and extension of these old Hindu walls was effected by the earliest governors and monarchs to form the first Muslim city of Delhi, known by the name of its former occupant as Qil'a Rāy Pithorā. (For a discussion of the archaeological evidence see J.D. Beglar, ASI, iv, 1874, 6 ff.)

Qil'a Rāy Pithorā remained the only regular residence of the Delhi sultans until Mu izz al-Dīn Kayqubād built his palace at Kilōkhrī, then on the banks of the Yamuna (Briggs, Ferishta, i, 274), in about 688/1289; this was occupied, completed, and its suburbs extended, by Jalāl al-Dīn Fīrūz Khaljī in and after 689/1290. It has now fallen completely into desuetude. Even in Jalāl al-Dīn's case the older city seems to have 
had a higher prestige value, and he moved his court there as soon as it was politically practicable so to do. The sultān 'Alā' al-Dīn Khaljī effected many improvements and repairs, including the west gate (Ranjīt Darwāza) of Lālkōt (Amīr Khusrau, trans. in Elliott and Dowson, iii, 561); he commenced also the extension of the citadel of Lālkōt (see Beglar, op. cit.). As a protection against the invading Mongols he first established a camp on the plain of Sīrī to the north, later encompassed it by entrenchments, and finally walled it, in about 703/1303. The location of Sīrī has been questioned (e.g., by C.J. Campbell, Notes on the history and topography of the ancient cities of Delhi, in FASB, xxxv, 1866, 206-14); but the descriptions of Ibn Bațțāța, iii, 146, 155, and Tīmūr, Malfüzāt-i Timmuri, trans. in Elliott and Dowson, iii, 447, and the ruins and lines of defences on the ground, enabled Campbell's views to be convincingly refuted by Cunningham in $A S I$, i, $207 \mathrm{ff}$. All that now remains within the walls is the comparatively modern village of Shahpur.

Hardly a "city of Delhi", but an important site in its history, is the group of buildings, the earliest of which date from Khalji times, surrounding the (Tughluqāāād) shrine of the Chishtī saint Nizạam al-Dīn Auliyā', which make up the complex now known officially as "Niz̄āmuddinn" (for description of these buildings, see below).

Some of the most ambitious building projects in the time of the Delhi Sultanate were conceived during the rule of the following Tughluq dynasty. Firstly, Ghiyāth al-Dīn Tughluq selected a site some $8 \mathrm{~km}$. to the east of Qil'a Rāy Pithorā, immediately after his defeat of the converted Hindu Nāṣir al-Dīn in 720/1320, for the building of his capital Tughluqābād. The trace of the outer enceinte is approximately a halfhexagon, within which are a more strongly defended palace area, and an even stronger citadel; there are the ruins of a mosque in the city area, and the layout of the streets and houses of the streets and houses of the city, which shows it to have been well populated, can be seen from the aerial photograph in $A I$, i, Pl. IX. On the south of the city was formerly an artificial lake, in which stands the tomb of Ghiyāth al-Dīn, linked to the citadel by a fortified passage supported on arches, itself fortified. Connected with Tughluqābād by a causeway on the south-east, which formed a bund to retain the waters of the lake, is the subsidiary fort of 'Ādilābād built by his son Muhammad b. Tughluq c. 725/1325, but abandoned by him, together with Tughluqābād, in 729/1329 on his transfer of the capital to Daulatabad. (For these sites see the excellent article of H. Waddington, 'Ádilābād: a part of the "fourth" Delhi, in AI, i, 60-76, with photographs and survey plans.) A small fort, known as the 
"Barber's" or "Washerman's" fort (Nāikā/Kōt), to the east possibly a madrasa or a shrine in origin, was fortified and presumably used as a residence for Ghiyāth al-Dīn while Tughluqābād was in building.

About contemporary with the building of 'Ādilābād was Muhammad b. Tughluq's more grandiose project, the walling-in of the suburbs which had grown up between Qil'a Rāy Pithorā and Sīrī to form yet another city, called Jahānpanāh, the walls of which, some $12 \mathrm{~m}$. thick, have almost completely fallen and the exact trace of which cannot easily be located; for the sluice built into this wall near the village of Khirkī, the Sāt Pulāh, see below.

Muhammad's successor Fīrūz Tughluq was responsible for the building of another city, Fīrūzābād, extending from Indrapat to Kushk-i Shikār some $3 \mathrm{~km}$. north-west of the later city of Shāhjahānābād, and now largely covered by that latter city. Its buildings were dilapidated by later builders, especially Shēr Shāh Sūrī and Shāhjahān, and all that remains is the citadel, known as Fìrūz Shāh Kōttā, its walls reduced to below the level of their machicolations, containing a palace complex, the remains of a fine mosque, and an extraordinary pyramidal structure built as a plinth for a column of Ashoka brought from near Ambala; the isolated Qadam Sharîf and the nearby 'ìdgäh show the western extent of the city to have been no further than the later Shāhjahānābād. The extent of Fīrūz Shāh's building activity around Delhi would indicate that the suburbs in his time were still well populated, as evidenced by the two large mosques in Jahānpanāh, another in Nizāamuddīn, and smaller ones in the northern suburbs and in Wazīrābād. A further occupied site was around the old reservoir built by 'Alā' al-Dīn, the Hauz-i 'Alā'î, later known as Hauz-i Khāṣs, where he established a large madrasa and built his own tomb.

The Tīmūrid sack caused the eclipse of Delhi as a capital city for some time, and although the Sayyid governor Khiḍr Khān established his court at Khiḍrābād, and Mubārak Shāh his at Mubārakābād, both on the Yamuna, and the latter sultān built also his own tomb in the fortified village Mubārakpur (also Mubārikpur, Mubārik [sic] Shāh Kōtlā), the Sayyids and their successors the Lōdīs built no further cities at Delhi. The Lōdīs, indeed, moved their seat of government to Agra, and Delhi became little more than a vast necropolis, the plains between Sīrī and Fīrūzābād being covered with tombs and mausolea of this period; especially Khayrpur, $2 \mathrm{~km}$. west of Nizāmuddīn, a region 1 km. west of Mubārikpur ("Tīn Burj", i.e., "three towers"), and a region on the road to Hauz-i Khāṣṣ (Kharērā); there was also some building 
in the region of the reservoir of Iletmish, Hauz-i Shamsī, south of the village of Mehraulī.

After the Mughal invasion in the early 16th century Humāyūn settled at Delhi and started the building of a citadel, Dīnpanāh, on the mound of the old Indrapat in 940/1533, but was dispossessed by the usurper Shēr Shāh Sūrī. Shēr Shāh took over and completed the building of Dīnpanāh, as the citadel of a new city, to which no particular name is given, little of which remains except the northern gate, near Fìrūz Shāh Kōtlā, and the southern gate, opposite the citadel, as most of the stone was removed for the building of Shāhjahānābād. His son and successor Islām Shāh, popularly called Salīm Shāh, built on the Yamuna the fortress Salīmgarh as a bulwark against the return of Humāyūn in about 957/1550. Humāyūn's return five years later added nothing to the Delhi buildings, and the next two Mughal rulers preferred to reside at Agra and Lahore; some buildings at Delhi date, however, from their time, especially the complex of monuments around Humāyun's tomb (see S.A.A. Naqvi, Humāyūn's tomb and adjacent buildings, Delhi 1947). Shāhjahān also reigned at Agra for 11 years, but the inconveniences there caused him to remove to Delhi ('Amal-i Sălih, fols. 575-6; Manucci, Storia do Mogor, i, 183) and found there on 12 Dhu 'l-Hijja 1048/16 April 1639 (so the contemporary historians and inscription in the Khwābgāh; 9 Muharram 1049/12 May 1639 according to the Ma'a-thir al-Umara ${ }^{\prime}$, iii, 464, and Sayyid Aḥmad Khān) a new fort, the citadel of his new city Shāhjahānābād, known as the "Red Fort", Lāl Qil'a, which was completed after nine years. The walling of the city proceeded at the same time, and it was enriched with many more buildings in the reign of Shāhjahān and his successors (notably the Jāmi` Masjid, commenced two years after the completion of the fort), who made no further expansions of any of the successive cities. Shāhjahānābād continued to be the capital of the Mughal rulers - except for Aurangzīb, who spent much time in the Deccan and died at Aurangabad - although other sites around continued to be used; e.g., the Humāyūn's tomb complex, Nizāamuddīn, and the dargāhs of Rōshan Chirāgh-i Dihlī in Jahānpanāh and of Quṭb al-Dīn Kākī at Mehraulī were all used as burial places for the later Mughal rulers, and at Mehrauli is a small summer palace used by the latest Mughals.

With the fall of the Mughal dynasty in 1858, the destruction of many buildings by the British during and after the mutiny, and the transfer of the capital to Calcutta, Delhi became a town of less importance, the head of a local administration and a garrison town. The British expan- 
sion was to the north of Shāhjahānābād, where the Civil Lines were established; here the capital was transferred in 1911, and the building of the new city commenced, originally known as Raisena, later New Delhi, Na乞 Dilli. Later expansion has been westwards of Shāhjahānābād in the Sabzī Mandī, Karōl Bāgh, and Șadr Bāzār quarters; south of Khayrpur and on the road to Mehraulī; around the Cantonment; and north of the Gurgaon road leading to the airport.

Some confusions of nomenclature, omitted in the above description, must be mentioned. Lālkōt and Kil'a Rāy Pithorā were known as "Old Delhi" as early as Tīmūr's time, and this phrase was in regular use in the early British period; since the building of New Delhi the expression "Old Delhi" has often been falsely applied to Shāhjahānābād. After the building of Shāhjahān's new fort, Lāl Qil'a, the older fort of Humāyūn and Shēr Shāh was regularly known as the "Old Fort", Purānā Qil'a or Qil'a-i kuhnā.

\section{Monuments, Sultanate Period}

As the buildings of Delhi present the earliest monuments of a settled Islamic power in the sub-continent, and as it was there that the first characteristic Indian Islamic styles developed, the influence of which was to spread far and wide from Delhi itself, the account of the monuments given here is confined to a simple description of the major works, arranged chronologically, and an account of the architectural features of the monumental complexes of buildings of different periods.

The earliest phase of Muslim building in Delhi is represented, as in the earliest stages in other sites by the re-utilization of pillaged Hindu temple material. This applied to the first mosque constructed in India, Quṭb al-Dīn Aybak's Masjid Quwwat al-Islām, earliest inscription 587/1191-2, in Qil'a Rāy Pithorā: on a temple plinth $37.8 \mathrm{~m}$. by $45.4 \mathrm{~m}$. is constructed the central court, $65.2 \mathrm{~m}$. by $45.4 \mathrm{~m}$., with colonnades of three bays on the east and two on north and south; the western tiw wan is four bays in depth, originally with five domes covering voids in front of the mihrāb recesses, its roof raised at the north end to accomodate a zanāna gallery. The lizwàn is separated from the mosque courtyard by a great arched screen, added in 595/1199, whose arches do not conform with the spacing of the columns and mihrābs behind. The columns of the arcades were taken from some 27 Hindu and Jain temples, arranged haphazardly, often set one over another to give the necessary height, ranged to support a roof made from ceiling slabs of 
similar temples, the sculptured figures mutilated and roughly covered with plaster, sometimes turned face inwards. The screen arches are corbelled, ogee at the top, some $2.5 \mathrm{~m}$. thick, the central arch $13.7 \mathrm{~m}$. high with a span of $6.7 \mathrm{~m}$. The whole surface of this maqsüra is covered with carving, Hindu floral motifs and arabesques, and vertical lines of naskh. In the courtyard stands a pillar of rustless malleable iron from a temple of Vishnu of the Gupta period (4th century), doubtless placed there by the builders not only as a curious relic, but also as a symbol of their triumph over the idolaters. At the south-east corner of the mosque Quṭb al-Dīn commenced, after the completion of his mosque, the minaret known as the Quṭb Mīnār, described below.

The reign of Quṭb al-Dīn's successor, Shams Dīn Iletmish, saw an increase in building, not only at Delhi. To the Delhi mosque he attempted to give greater scale and dignity by extensions of the colonnades and the great maqșüra screen - symmetrically disposed as regards the new milhräbs, columnar bays, and the arches of the maqșura, thus indicating a design of homogeneous conception; the new sahn included the mina $r$, to which he added also, and its entrances were arranged coaxially with those of the old mosque. The colonnade is composed of relatively plain columns, and the screen decoration, including Kūfic character and tughra devices, is more obviously the work of a craftsman familiar with his material than is the earlier example. The arches, still corbelled, differ in contour from those of the earlier screen by the absence of the ogee counter-curve at the apex. Immediately west of his northern extension of the mosque is the tomb of Iletmish (c. 632/1235?; no dating inscriptions), a square chamber, originally bearing a circular dome, supported on corbelled squinches, the whole interior surface intricately banded with arabesques, diaperwork, and naskh and Küfic inscriptions (entirely Qur'annic); the exterior is of dressed ashlar, with the arched openings on north, east and south in red sandstone; red sandstone is also used for the interior, with marble on the mihra $\bar{a} b$ wall and the cenotaph; the true grave is in a subterranean tahkhāna.

The Quṭb Mīnār was extended by Iletmish by the addition of three further storeys, to a total height of $69.7 \mathrm{~m}$. (Cunningham, ASI, i, 195), completed c. $626 / 1229$. The angle of slope is about $41^{1} 2^{\circ}$ from the vertical, and the four storeys are separated by balconies supported by stalactite corbelling. Each storey is fluted - developing probably the polygonal outline of the prototype minnar at Ghazni in Afghanistan - the lowest having alternately rounded and angular flutes, the second all rounded, the third all angular; the upper storeys, the work of Fìrūz 
Tughluq (see below), are plain. Each of the three lowest storeys is decorated with wide encircling bands of Arabic inscriptions in naskh (dating inscriptions, panegyrics of Mu izz al-Dīn Muhammad b. Sām and Shams Dīn Iletmish, Qur'ānic verses); features of typically Hindu origin are almost entirely absent.

To the reign of Iletmish belongs the first instance in India of a monumental tomb, the mausoleum of his son Nāṣir al-Dīn Maḥmūd, at Malikpur, of 629/1231. This stands within a plinth some $3 \mathrm{~m}$. high in an octagonal cell, the top of which projects into a courtyard with a plain enclosure wall pierced by corbelled arches, with arcades of Hindu columns on the east and west walls; that on the west forms a small mosque, with central portico and mihrāb. The external gateway bears the dating inscription in Kūfic characters (non-Qur'ānic inscriptions in Kūfic are known only here, at the Masjid Quwwat al-Islām, and at Ajmer); the corner towers appear to be part of Fīrūz Tughluq's restorations (Futūhāt-i Firūz Shāhī, Aligarh ed. 1943, 16). The tomb is locally known as "Sulțān Ghārî", presumably on account of the crypt $(g h \bar{a} r)$ in which Nāṣir al-Dīn is buried, but this name is not known before Sayyid Aḥmad Khān, Āthār al-Sanād̄̄d, lith. Delhi 1848, 206-8. For a detailed study see S.A.A. Naqvi, Sultān Ghārī, Delhi, in AI, iii, 1947, 4-10 and Pls. I-XII.

During the reigns of the suceeding sovereigns no buildings of note were erected until the reign of the Khaljī ruler 'Alā' al-Dīn, except for the tomb of the Sultān Balban, d. 686/1287, in the south-east of Qil'a Rāy Pithorā, larger than the tomb of Iletmish, with side chambers leading off the main hall, in which appears for the first time the use of the true voussoired arch. This marks not only a technical advance in construction but also a strengthening of Islamic building tradition, as opposed to that of the impressed Hindu craftsmen.

'Alā' al-Dīn Khaljī's extensions to the citadel of Lālkōt, and the building of Sīrī, have been mentioned above. He started a grandiose plan of extension to the Quwwat al-Islām mosque to the north and east; a few columns remain, and the foundations of the north gateway, to show the extent of this, and of the great arched maqsüra screen which was intended to be twice as long as the two previous screens combined, and of twice the scale; in the northern courtyard stands the incomplete first storey of a gigantic minār, its diameter at base twice that of the Quṭb Mīnār. The most notable feature of these extensions is the southern gateway, the 'Alā's Darwāza, of exceptional architectural merit: a square building of $10.5 \mathrm{~m}$. internal dimension, with walls 3.4 
m. thick, is surmounted by a flat dome, with lofty $(10.7 \mathrm{~m}$. from ground level to apex) arches on east, south and west, and a smaller trefoil arch on the north leading to the new eastern extension of the courtyard. The three large arches, and the squinches which support the dome, are of pointed horse-shoe shape, voussoired, with on the intrados a fringe of conventionalized spear-heads. A similar style is seen in the Jamā'at Khāna Dargāh of Niẓām al-Dīn, the first example in India of a mosque built with specially quarried materials, not improvised from Hindu material. (For a discussion of this mosque see M. Zafar Hasan, $A$ guide to Nizämu-d-Din [= MASI, 10], 1922). Apart from the early building (madrasa?) at Hauz 'Alā'̄i (= Hauz-i Khāșș), the only other structure of 'Alā' al-Dīn at Delhi is his tomb and madrasa to the south-west of the Masjid Quwwat al-Islām, now much ruined; the series of small cells on the west wall show for the first time in India domes supported by a corbelled pendentive. For an extensive description of all the monuments and archaeological work see J.A. Page, Historical Memoir on the Qutb, Delhi (= MASI, 22), 1925; idem, Guide to the Qutb, Delhi (abridged from above, with map), Delhi 1938; best illustrations in H.H. Cole, The architecture of ancient Delhi, London 1872.

The achievements of Ghiyāth al-Dīn, the founder of the Tughluq dynasty, are confined to the building of the city of Tughluqābād (see above), and his own two tomb buildings; the first of these is in Multan; the second of these, commenced after leaving the Panjab and coming to Delhi as sovereign, forms an outwork on the south side of Tughluqābād, an irregular pentagon with bastions at each angle, with the tomb-building placed diagonally at the widest part of the enclosed courtyard. This mausoleum is of red sandstone faced with white marble, its walls with a strong batter $\left(25^{\circ}\right.$ the vertical), with a recessed archway in the north, east and south sides (the west side closed for the mihräb) with the "spear-head" fringe introduced under the Khaljīs and a slight ogee curve at the apex. Here the old Hindu trabeate system is joined with the newer arcuate by a lintel being imposed across the base of the arch.

Muhammad b. Tughluq's foundation of 'Ādilābād and Jahānpanāh has been mentioned above; in the walling of the second of these is a sluice or regulator of seven spans, the Sāt Pulāh, with subsidiary arches and end towers, its two storeys of seven arches holding the mechanism for regulating the level of a lake contained within the walls. Another building of his time, near the village of Begampur, is the Bijay Mandal, which has been supposed to be the remains of his Qașr-i Hazār Sitūn, 
with the first example of intersecting vaulting in India; close to this is a superb but nameless tomb, and the Bārah Khambā (see below).

Muhammad b. Tughluq's act in transporting the entire elite population of Delhi to Daulatabad resulted in the dispersal of the northern craftsmen, and the introduction of a rubble-and-plaster phase under the enthusiastic patronage of his successor Fīrūz Shāh (752-90/1351-88). A list of the numerous building projects sponsored by this monarch is given by Shams-i Sirāj 'Afîf, Ta'rīkh-i Fìrūz Shāhì, and by Firishta, and in his own Futūhät-i Fìrūz Shāhi he describes the monuments of his predecessors which he had rebuilt or renovated. These numerous building and restoration projects demanded a strict economy: plans for every undertaking were submitted to the dīwān-i wizāra, and the more expensive building materials, red sandstone and marble, were no longer used. Of Fīrūz Shāh's cities, Fìrūzābād has been mentioned above. The Jāmi 'Masjid within the kōtla stands on a high plinth and the main gate is on the north; the saln was surrounded by deep triple aisles, and around the central octagonal hauz was inscribed the record of the public works of Fìrūz. Only the shell of the building remains, much of the stone having been built into the walls of Shāhjahānābād by British engineers. The other building standing within the kōtla is a three-storeyed pyramidal structure on which is mounted a pillar of Ashoka (3rd century B.C.) brought from Meerut District. For these and other ruins in the citadel see J.A. Page, A memoir on Kotla Firoz Shah, Delhi (= MASI, 52), Delhi 1937. The mosque style of the period is better shown by half a dozen mosques of approximately the decade 766-76/1364-75: all are rubble-and-plaster, presumably originally whitewashed, with pillars and Hindu style brackets and eaves in local grey granite, with prominent gateways, many domed roofs, and tapering ornamental pillars flanking the gateways. The simplest is the mosque in the dargāh of Shāh 'Ālam at Wazīrābād (= Tīmūrpur), a simple west tizeann of five bays, with three domes, within which is the earliest example in Delhi of a zanāna gallery in the rear corner of the tìwan; the large (courtyard $68.0 \mathrm{~m}$. by $75.3 \mathrm{~m}$.) Begampur mosque in the north of Jahānpanāh has the șahn surrounded on all sides by a domed arcade, and the west liwe $\bar{a} n$ has a tall arched pylon in the centre of its façade which completely masks the large central dome; the Sanjar mosque (also called Kālī [black] Masjid) at Nizāmuddīn has the central courtyard divided into four smaller courts each $13.1 \mathrm{~m}$. by $10.1 \mathrm{~m}$. by a cruciform arcade one bay in depth, as well as the domed arcading on all sides (ASI AR, xxvii, Pl. I); the Khirkī mosque, at Khirkī village in 
the south of Jahānpanāh close to the Sāt Pulāh, has a similar arrangement, but the crossing arcades are of three ranks of arches, as are the side liwwāns: hence only the four courts, each $9.8 \mathrm{~m}$. square, are open in the total area of about $52 \mathrm{~m}$. square; the Kalān (this also sometimes miscalled Kālì) Masjid, within the walls of the later Shāhjahānābād, is smaller with a single open court and surrounding domed arcades. This, the Khirkī mosque, and the Jāmi ${ }^{`}$ Masjid in the kōtlāa, are all built on a high plinth over a tahkhāna storey, and the mosques themselves are approached by high flights of steps. The Kalān Masjid was no doubt the main mosque of the new Fìrūzābād suburbs, but the size of the Begampur and Khirkī mosques implies that the older cities still maintained a considerable population. The northern suburbs were further provided for by the Chauburjī mosque on the Ridge, now so altered through various uses that its original plan is hardly discernible; near the mosque is the remains of Fìrūz Shāh's hunting lodge, Kushk-i Shikār or Jahān-numā, to which he repaired for consolation after the death of his son, Fath Khān, in 776/1374. This prince is buried in the Qadam Sharîf, a fortified enclosure (see $A S I A R$, xxii, 4 and Pls. IIIc and d) in which is a domed arcade surrounding the grave, over which is a stone print of the Prophet's foot set in a small tank of water.

Fìrūz's own tomb is coupled with the madrasa he built on the site of 'Alā' al-Dīn's structure at the Hauz-i Khāṣs; the madrasa buildings on the east and south of the hauz, double-storeyed on the lake front and single behind, are colonnades, several bays deep, of arches or linteland-bracket construction, connecting square domed halls at intervals, extending about $76 \mathrm{~m}$. on one shore and $120 \mathrm{~m}$. on the other; at the south-east corner is the $13.7 \mathrm{~m}$. square tomb, with plastered walls slightly battering, the two outer (south and east) walls with a slight projection in which is an arched opening in which the entrance is framed by a lintel-and-bracket; there is a single dome on an octagonal drum, supported by interior squinches, and the west wall, in which is a door to the adjoining hall, has a small mihrāb. The building stands on a short plinth extended southward to form a small terrace, which is surrounded by a stone railing of mortice and tenon construction resembling woodwork. Another tomb, of great architectural significance, is that of Fìrūz's Prime Minister Khān-i Jahān Tilangānī, d. 770/1368-9, within the kōt at Nizāmuddīn; this is the first octagonal tomb at Delhi (although the tomb-chamber at Sulțān Ghārī is octagonal also), and is surrounded by a verandah, each side of which has three arched openings surmounted by a wide chhajj $\bar{a}$ or eaves-stone; there is a central dome, and eight 
smaller dome-like cupolas, one over each face. The prototype of this tomb has been sought in the Dome of the Rock in Jerusalem; it formed the model for many royal tombs of the subsequent "Sayyid", Lōdī and Sūrī dynasties. One of the latest buildings of the Tughluqs is the tomb of the shaykh Kabīr al-Dīn Auliyāà (probably of the time of Nāșir al-Dīn Mạmūē, after 796/1394); although an indifferent (Nizāmuddīn) and half-scale copy of the tomb of Ghiyāth Dīn Tughluq, it is of interest in indicating a revival of sympathy for the earlier polychromatic style, a reaction against the Fīrūzian austerity. On Fìrūz Shāh's tunnels at Delhi, see H. Hosten, in $\mathcal{J A S B}$, n.s. vii (1911), 99-108; viii (1912), 279-81; ix (1913), lxxxiii-xci.

Since the major structures at the shrine of Nizām al-Dīn are of this time the complex is described here. The entrance gate bears the date $780 / 1378-9$, within which is a large $b \bar{a} o l \bar{t}$ flanked by two tombs and a two-storeyed mosque, all of Fìrūzian appearance; the $b \bar{a}$ olt is named Chashma-i dil kushā $(=703 / 1303-4$ by abjad $)$. A further gate leads to the shrine enclosure; the shaykh's tomb dates from the time of Akbar, replacing an earlier one built by Fīrūz Tughluq, but has been much restored since, the dome being an addition of Akbar Shāh II in 1823; the Jamā'a Khāna mosque, to the west of the tomb, has already been referred to. To the south of the enclosure are numerous graves (Jahānārā, daughter of Shāhjahān; Muhammad Shāh, d. 1161/1748; Jahāngīr, son of Akbar II; Amīr Khusrau, a contemporary of the shaykh, although the tomb is early 17th century; and others); outside the east wall of the court is the square polychromatic tomb of Atga Khān, foster-father of Akbar, d. 969/1562, of a style similar to that of Humāyūn (see below). Some $60 \mathrm{~m}$. south-east of this tomb is the Chausath Khambe, a grey marble pavilion of excellent proportions forming the family burial place of Atga Khān's son, Mīrzā 'Azīz Kōkaltash, d. 1033/1624. The adjoining kōt and Tilangānī tomb have already been noticed. For a full account of all these buildings see M. Zafar Hasan, A guide to Nizāmu-d-Din (= MASI, 10), Calcutta 1922.

Another dargāh largely dating from Fūrūz's times is that of Nașir alDīn Chirāgh-i Dihlī, d. 757/1356; the east gate is of 775/1373, but the tomb has been much modernized; the walls enclosing the shrine and village were built by Muhammad Shāh in 1142/1729; beside stands one of the alleged tombs of Bahlōl Lōdī.

The "Sayyid" and Lōdī dynasties produced no great building projects; their monuments consist entirely of tombs, except for one significant mosque, and the principal ones are concentrated in three sites: 
Khayrpur, Mubārakpur, and south of Mujāhidpur on the road to Hauz-i Khāș. The tombs are of two distinct types, square and octagonal, in both cases with a large central dome, frequently also with open chhatris above the parapets. The earliest octagonal example is that of Mubārak Shāh, d. 838/1434, in Kōtlā Mubārakpur, an improvement on the style of the Tilangāni tomb, although the dome is not high enough and the octagonal chhatris over each face are too crowded. The tomb of Muhammad Shāh, ten years later, removes these defects by raising the drum of the dome and the chhatris, andadding a guldasta at each angle of the verandah parapet. The tomb of Sikandar Lōdī, c. 924/1518, at the north end of Khayrpur, is of similar proportions but without the chhatris, and the dome has an inner and outer shell; the mausoleum stands in a fortified enclosure, on the west wall of which is an arrangement of arches resembling an $\bar{\imath} d g \bar{a} h$, presumably an outdoor mihra $\bar{a} b$. The tomb of Mubārak has a detached mosque, but that of Muhammad has none. All tombs have sloping buttresses at the angles.

The square tombs probably all date from the last quarter of the 15th century, but they lack inscriptions and are known only by very uninformative local names. The finest is the Barē Khān kā Gunbad, "Big Khān's dome", the largest (height $25 \mathrm{~m}$.) of the three known as Tīn Burj, west of Mubārakpur, apparently of three storeys from the exterior, but actually a single hall; this and the adjoining "Little Khān's dome" have octagonal chhatris in the angles of the square below the drum, as had the Dādī kā ("Grandmother's") and Potī kā ("Granddaughter's") Gunbad of the Mujāhidpur group. At Khayrpur are the best preserved, the Barā Gunbad ("Big dome"), date 899/1494, which has no graves within and is locally said to be a gateway to the attached mosque, court-yard and majlis-khana (?). The mosque has massive tapering and sloping pillars at each rear angle, each with a band of fluting, alternately rounded and angled, reminiscent of the lowest storey of the Quṭb Mīnār; the east façade has wide central arches whose spandrels are filled with the best cut-plaster decoration in Delhi. Near is the Shīsh Gunbad, very similar to the Barā Gunbad, but with courses of dark blue encaustic tile work.

Apart from the mosque mentioned above, the Lōdīs produced one major example of this class, the isolated Moth ki Masjid south of Mubārakpur, built by the wazìr of Sikandar Lōdī c. 911/1505; the west wall shows similar tapering pillar-turrets, but at the angles of the projecting mihrāb, and the external angles are provided with two-storeyed 
open towers; the side walls have trabeate balconies; the façade of the west lizwan has the contours of the arches emphasized by the recession of planes of the intrados, and the central arch is emphasized further by a pylon-like structure of the same height as the remainder; the liw $\bar{a} n$ side domes are supported on stalactite pendentives; white marble, red sandstone, and coloured encaustic tiles are used in the decorative scheme, as well as fine cut-plaster; it is aesthetically one of the liveliest buildings in the whole of Islamic art in India. Other buildings of the Lōdīs are few: a structure (madrasa?), incorporating a small mosque, known as the Jahāz Mahall, on the east side of the Hauz-i 'Alā'ì at Mehraulī, a few small bāradarìs and mahalls near Niz̄āmuddīn, and the residence (Bārah Khambā), with enclosed courtyard and three-storeyed tower, at Begampur.

In the unsettled days of the early Mughal conquest the Lōdī mode seems to have continued: the Jamāli mosque of 943/1536, in the south of Qil'a Rāy Pithōrā, has fine ashlar masonry, five tìwān arches with recession of planes in the intrados, and the central archway sunk in a larger arch, with a spearhead fringe, in a central propylon rising above the general level of the façade, with a single central dome. Immediately to the north is the insignificant-looking oblong building over the tomb of Fazl Allāh, takhallus Jamālī, with the best colour decoration in Delhi on its ceiling. A continuation of the octagonal tomb style is in that of '̄̄sā Khān Niyāzī, of 954/1547-8, and hence in the reign of Islām Shāh Sūrī; the construction is similar to the preceding examples, including the closed west wall and mihrāb, but more encaustic tile remains; a separate mosque stands on the west of the octagonal courtyard, of grey quartzite and red sandstone, the central bay of the three set in a projecting portico, with a central dome and chhatrīs over the side bays. The tomb-building has sloping buttresses at each angle, and is the last building in Delhi so treated. (For these monuments see Naqvi, Humāyunn's tomb...op. cit., 21-4). The last octagonal tomb in Delhi was built some fourteen years later, in the reign of Akbar, the tomb of Adham Khān in the extreme south-west of Qil'a Rāy Pithōrā; this seeks to obtain additional elevation by converting the drum of the dome into an intermediate storey, arcaded externally, and without chhatris; the thick walls of the drum contain a labyrinth of stairways. Its general effect, though, is rather spiritless (photograph and brief description in Cole, op. cit.). 


\section{Monuments, Mughal period}

The first two Mughal emperors, Bābur and Humāyūn in his first period, added nothing to Delhi's monuments, except perhaps the commencement of the Purānā Qil'a; this, however, was mostly the work of the usurper Shēr Shāh Sūrī, as a citadel for his new city. Of the city only two gateways remain, the northern (Lāl, Kābulī or Khūnī Darwāza), opposite Fīrūz Shāh Kōtlā, and the southern, with a short stretch of walling, near Purānā Qil'a (see $A S I A R$, xxii, 6 and Pl. II). Of the citadel the walls remain, and two major structures within, the Shēr Mandal, a two-storeyed octagon of red sandstone of unknown original purpose, but used by Humāyūn as a library and from which he fell to his death; and the mosque, with no distinctive name, which has the Jamāli mosque as its immediate prototype: but each of the five façade bays has a smaller recessed archway, and every other feature of the earlier mosque is improved and refined in this later example. The external construction is in coursed ashlar, and the liw $w \bar{a}$ façade in red sandstone, some of it finely carved, embellished with white marble and polychromatic encaustic tile work; inside the central dome is supported by two ranks of squinches, and in the side bays stalactite pendentives support the roof; the rear wall has tapering turrets on each side of the milhräb projection, and an open octagonal turret at each angle.

The first major building of the Mughals in Delhi is the tomb of the emperor Humāyūn, of a style already prefigured in the small tomb of Atga Khān at Nizāmuddīn; the foundations of it were laid in 976/1568-9 (so Sangīn Beg, Siyar al-Manāzil, MS in Delhi Fort Museum; 973/1565 according to Sayyid Ahmad Khān, followed by most later writers) by his widow, employing the Persian architect Mirzā Ghiyāth, although the enclosure wall had been started some five years before. In a large square garden enclosure ( $340 \mathrm{~m}$. side; this is the first chār-bāgh garden in India still preserving its original plan) stands the mausoleum building, $47.5 \mathrm{~m}$. square on a plinth $95 \mathrm{~m}$. square, $6.7 \mathrm{~m}$. high; each face is alike, having a central rectangular fronton containing an immense arch, flanked by smaller wings each containing a smaller arch; these wings are octagonal in plan and project in front of the main arches. The central chamber is surmounted by a bulbous double dome on a high collar, around which are chhatrīs over the corner wings and portals. The entire building is in red sandstone, with a liberal use of white and coloured marble. Neighbouring structures are the small $\mathrm{Na}_{\bar{a}} \overline{\mathbf{1}}$ kā Gunbad, "Barber's dome"; the Nīlā Gunbad, "Blue dome", earlier 
than Humāyūn's tomb and therefore not the tomb of Fahīm Khān, d. 1035/1626, as often stated; the "Afsarwālā" tomb and mosque; the 'Arab Sarā'ī; and the tomb of 'Īsā Khān already described (full description of these buildings in Naqvi, Humāyunn's tomb...op. cit.). Not far to the south is the tomb of 'Abd al-Rahīm, Khān-i Khānān, d. 1036/ 1626-7, a similar structure but smaller and without the octagonal corner compartments - hence a more obvious forerunner of the Tāj Mahall than Humāyūn's tomb; the white marble of this building was later stripped off by Āsaf ad-Daula, wazīr of Awadh. Other early Mughal buildings are the Lāl Chauk or Khayr al-Manāzil (the latter name a chronogram, $969=1561-2$ ), a mosque built by Māham Anaga, foster-mother of Akbar, with double-storeyed chambers on east, south and north forming a madrasa (ASI AR, xxii, 6 and Pls. Ia and b; inscriptions, MASI, 47, 10); and the mosque of Shaykh 'Abd al-Nabī, șadr al-ṣudūr of Akbar, between Fīrūz Shāh Kōtlā and the Purānā Qil'a, built 983/1575-6 (see M. Zafar Hasan, Mosque of Shaikh 'Abdu-n Nabi (= MASI, 9), Calcutta 1921).

The main phase of Mughal building in Delhi was the construction of Shāhjahānābād and the Red Fort, Lāl Qil'a, founded 1048/1638. Within the palace enclosure, about 950 by $505 \mathrm{~m}$., are a central court containing the Dīwān-i 'Āmm; flanking this, two open spaces containing gardens; and, on the eastern wall, the range of palaces facing inwards to the gardens and outwards to the river. The Dīwān-i 'Āmm is of red sandstone, with slender double columns on the open sides; this and the palace buildings on the east have engrailed arches, stand on low plinths, and most have open chhatris at each corner of the roof. Through the palaces runs an ornamental canal, the Nahr-i Bihisht, which flows south from the Shāh Burj, water being brought from a point $30 k \bar{s}$ up the Yamuna (through the Western Yamuna canal; for the history of this, which dates from the time of Fīrūz Shāh Tughluq, see J.J. Hatten, History and description of government canals in the Punjab, Lahore n.d., 1-3); this has a plain marble channel, which in the Rang Mahall flows into a large tank in which is set a marble lotus, having previously passed, in the royal private apartments, under a screen bearing a representation of the "Scales of Justice" (mizzann-i 'adl). Off these apartments is the external octagonal balcony, the Muthamman Burj, from which the emperor gave the darshan. The Rang Mahall and the Dīwān-i Khāṣṣ are the most lavishly ornate of these palaces, built and paved in white marble, the piers of the arches inlaid with floral designs in pietra dura; the latter building contained the fabulous Peacock Throne (takht-i țâuss), taken to 
Persia by Nādir Shāh in 1152/1739 and there broken up (G.N. Gurzon, Persia and the Persian question, i, 321-2). The fort originally contained no mosque; the Mōtī Masjid was added by Aurangzīb in 1073/1662-3, entirely of white marble, with a curved "Bengali" cornice over the central bay. For the fort and its buildings, see G. Sanderson, $A$ guide to the buildings and gardens, Delhi Fort, Delhi 1937.

The Jāmi` Masjid of Shāhjahānābād (named Masjid-i Jahān-numāa), built 1057-9/1648-50, stands on an open plain to the west of the Lāl Qil'a, its high basement storey, with blind arches on all sides, built on an outcrop of the local Aravalli ridge. The gates on north, east and south have an external opening in the form of a half-dome with a smaller door in the base of each. The east gate, used as the royal entrance, is the largest. The tiwan surrounding the court is open to the outside, and has a square burj, surmounted by an open chhatri, at each angle. The western sanctuary is a detached compartment $79 \mathrm{~m}$. by $27.5 \mathrm{~m}$. with the (Lāl Qil'a) courtyard (99 m. square), with a wide central arch flanked by five smaller bays of engrailed arches on each side, and a three-storeyed minaret at each front angle; above are three bulbous domes of white marble with slender vertical stripes of black marble. The mosque as a whole is in red sandstone, with white marble facings on the sanctuary, and white marble vertical stripes on the minarets. Nearly contemporary is the Fathpurī Masjid at the west end of Chandnī Chauk, the main street of Shāhjahānābād, of similar style but less refinement, with a single dome; there is a mosque school within the enclosure. A smaller mosque of similar style, but with the three domes more bulbous and with equal black and white marble stripes, is the Zinnat al-Masājid, c. 1112/1700, in the east (river) quarter of Shāhjahānābād.

Of the latest Mughal phase must be mentioned the Mōtī Masjid in the dargāh of Quṭb al-Dīn Auliyā' at Mehraulī (early 18th century); the tomb, madrasa and mosque of Ghāzī al-Dīn Khān, father of Āṣaf Jāh, in a hornwork outside the Ajmer gate of Shāhjahānābād (1122/1710), and where the Arabic school is still maintained; the gateway of the Qudsiya Bāgh, north of the Kashmir gate, c. 1163/1750, and the elegant diminutive mosque (Sonahrī Masjid ) of Jāwid Khān, of fawncoloured sandstone, of the same time; and the finely-proportioned fawn sandstone tomb of Safdar Jang, d. 1166/1753, standing in the last great Mughal garden.

The vast building projects of New Delhi ( $\mathrm{Na} \imath \mathrm{Dill} \bar{\imath})$ show occasional reminiscences of the glory of Mughal building, but have no further Islamic significance. 


\section{DHAR*}

From the architectural point of view the monuments of Dhar are important only as illustration of the earliest phase of the Malwa style, one of the characteristic provincial styles of Indian Islamic architecture. The earliest mosque building is that in the tomb enclosure of Kamāl Dīn Mālawī (locally called Kamāl Maula), a disciple of Niz̄ām al-Dīn Auliyā' of Delhi; the oldest grave inscription in this enclosure is of 795/1392-3, which records that the ruling sovereign was Mahmūd Tughluq, whose local representative was Dilāwar Khān. This, and the slightly later Jāmi 'Masjid, are both adaptations from pillaged Hindu temple material, of trabeate construction; the outer portico of the Jāmi Masjid shows an attempt to integrate the trabeate façade by the interposing of pointed arches, of no structural significance, between the columns, the forerunner of the arrangement in the mosque of Malik Mughith at Mandu. The Jāmic Masjid bears inscriptions of 807/1404-5 on the east entrance, and of 15 Rajab 807/17 January 1405 on the north entrance (presumably misread by Jahāngīr, Tūzuk-i Jahāngīn, Persian text 201-2); for these see EIM, 1909-10, 11-2 and Pls. III and IV. A third mosque of similar style and date is the so-called School of Rājā Bhoj, which owes its misnomer to numerous paving slabs and pillar stones carved with mnemonic rules of Sanskrit grammar.

Later buildings almost all owe their origin to the first Khaljī ruler of Malwa, Maḥmūd Shāh (839-873/1436-69), including the restoration of perhaps the oldest Muslim tomb in Dhar, that of 'Abd Allāh Shāh Changāl, who is said to have converted "Rājā Bhōj" to Islam; it has been disputed whether this refers to Bhōja I (r. 1010-1053), a broadminded and tolerant but nevertheless strict Shaiva Hindu - in which case this pir could perhaps have come to Malwa with the army of Mahmūd of Ghazni - or to Bhōja II (r. 1280-1310), at a time when conversion to Islam might have been politically expedient for the ruler of a small state; nothing is known of this pīr, and the story of Bhōja's conversion is now regarded as most doubtful, but the inscription erected by Maḥmūd Shāh in 859/1455 (EIM, 1909-10, 1-5 and Pl. I; 42 couplets of Persian verse, one of the longest Persian inscriptions in India) shows the then implicit belief in this tradition. To Maḥmūd Shāh is due also the restoration of the tomb of Kamāl Dīn (inscription over doorway of

\footnotetext{
* “Dhār, 2. Monuments," EI, II, 219.
} 
861/1456-7); a tomb opposite that of the pir is said by local tradition to be Mahmūd's own.

The Jāmi Masjid is known in later times as the Lāt Masjid, from the iron pillar $(l \bar{a} t)$ - probably a victory pillar of a local Paramāra king in the early 13th century, cf. ASI AR, 1902-3, 203-lying outside; this pillar bears an inscription recording Akbar's brief stay in Dhar in 1008/1599, its position showing that the pillar had already fallen.

The fort, now empty of internal buildings, is said to have been built by Muhammad b. Tughluq on his way to the conquest of the Deccan; no adequate description of it exists.

\section{ETAWA*}

A district in the south-west of Uttar Pradesh, and also the principal town of that district on the river Yamuna. Other forms of spelling of the name of Etawa are Etaya (Elphinstone), Itay (de Laet), and sometimes Intawa in the Muslim chronicles. Popular etymology connects the name with int $\bar{a} w \bar{a}$, "brick kiln".

The region of Etawa was probably within the kingdom of Kanauj at the time of the raid on that kingdom by Mahmūd of Ghazni in 409/1018, and again at the capture of Kanauj by Quṭ al-Dīn Aybak for Muhammad b. Sām in 589/1193. Many Rājpūt chieftains seem to have brought their clans to settle in this region in the early 13 th century, and gathered round them the more turbulent of the disaffected Hindu population. Their intransigence persisted, and many expeditions to enforce the payment of revenues were launched by successive Delhi sultāns; thus Fīrūz Shāh Tughluq was compelled to put down a rebellion of zamīndārs there in 779/1377 (Yahyā b. Ahmad, Tảrīkh-i Mubārak Shāhī, ed. Bibl. Ind., Calcutta 1931, 133-4; tr. K.K. Basu, Baroda 1932, 141; Firishta, Lucknow lith., i, 148); the refractory chieftains Sumer Sāh, Bīr Singh and Rāwat Uddharan - these names are much distorted in the Muslim chronicles and their translations - were in 794/1391-2 defeated by the sulțān Nāṣir al-Dīn Muhammad Tughluq in person, who is said (Yahyā b. Ahmad, op. cit., 152, tr. 161) to have destroyed the fort, although references to a fort abound in later years. Mahmūd Tughluq's governor, the Khwāja-i Jahān Malik Sarwar, began his gov-

\footnotetext{
* "Itāwa," EI, IV, 276-7.
} 
ernorship by leading a force against the rebels of Etawa and Kanauj in Rajab 796/May 1394 (Yahyā b. Aḥmad, op. cit., 156, tr. 164). After this time the Etawa region, lying between the spheres of influence of the Jaunpur sultāns and the factions contending for power at Delhi, was frequently invaded from both sides; thus by Mallū Khān Lōdī in 803/1400-1 (Yahyā b. Aḥmad, op. cit., 169 ff., tr. 175 ff.) and again in 807/1404-5, when after a four months' siege the rebels offered tribute and a gift of elephants. In 817/1414, shortly after his accession, the Delhi sulțān Khiḍr Khān the Sayyid sent out a large force under Tāj al-Mulk who, having received homage from Sumer and others, punished the infidels of Etawa (kuffär-i itāwa rā gūshmāl dāada; ibid., 185); he led further expeditions there in 821/1418 and 823/1420 when the village of Dihuli (Deoli, Duhli, even Delhi in translations!) was destroyed and Sumer besieged in Etawa. It would thus appear that the annual revenues of the district could be collected only by armed force, and only in 825/1422, when the son of Sumer had temporarily joined the forces of Mubārak Shāh, was no foray made against this region.

After the conclusion of a further expedition in 831/1427 the region was invaded by the army of the Jaunpur sultān Ibrāhīm under his brother Mukhtaș Khān, and the Delhi army had to return to meet the danger; not for two years, however, could an army be spared to bring Etawa again under subjection, but Sayyid power was declining and the fragmentation of the old Delhi Sultanate left the district little disturbed thereafter. In the division of the lower $D \bar{o}^{-} \bar{a} b$ territories between the first Lōdī sulțān, Bahlūl, and Maḥmūd Shāh Sharqī in 855/1451, Etawa passed to Jaunpur. A series of inconclusive disputes followed between Bahlūl and the three successive Jaunpur sulțans Mahmūd, Muhammad and Husayn, the last of whom seems to have made Etawa his temporary headquarters ("Bībī Rājì̄" the queen mother died here in 891/1486), and in 892/1487 Husayn's attack on Bahlūl was repulsed and Etawa taken for the Lōdī kingdom. It remained in Lōdī hands until 934/1528 when, on Bābur's invasion of the district, it was surrendered to him.

After the defeat of Humāyūn in 952/1545 the region passed to Shēr Shāh, who effected the partial pacification of the district by bringing in a force of 12,000 horsemen and by his efforts in opening up the country through a road building programme. Neither he nor Akbar seems to have found its absorption into the state administration easy, although it retained some prestige when Akbar made the town of Etawa the chief headquarters of a pargana; the town is mentioned in the $\bar{A} i \bar{\imath}-i$ Akbari as possessing a brick fort, and some reference is occasionally made to Etawa 
as a banking centre. It seems never to have been settled by Muslims to the same extent as other towns of the $D \bar{o}$ a $b$, and after the decline of the Mughal power fell into Marāthā or Jāt hands, with Awadh sometimes powerful enough to gain control over it. Even after the district became part of the lands ceded by Awadh to the East India Company in 1801, many local chiefs retained a considerable measure of independence; the town had some prominence in the struggles of 1857.

\section{Monuments}

Etawa town has an interesting Jami' Masjid, built out of Hindu temple spoli, the western tiwe an of which has a massive central propylon-type arch similar to those of the Jaunpur mosques; it has not been adequately studied, the only account being C. Horne, Notes on the Jumma Masjid of Etawah, in $\mathcal{F A S B}$, xxxvi/1 (1867), 74-5. The central square of Etawa is called "Humeganj", the name commemorating A.O. Hume, the Scots Collector of the district who played a prominent part in the foundation of the Indian Congress Party.

\section{GAWILGARH*}

Gawilgarh, or merely Gawil, a fortress "of almost matchless strength" (Abu 'l-Fazl, A' '̀n-i Akbarī, Eng. tr. Jarrett, ii, 237) is situated in Berar, Central India, $7 k \bar{s}$ (about $25 \mathrm{~km}$.) north-west of Elichpur. According to Firishta the fortress was built by Aḥmad Shāh Walī Bahman̄̄ in 829/1425-6; but from its name it appears to have been a former stronghold of the Gāwalī chiefs, and it is more likely that Ahmad Shāh merely strengthened the fortifications during the year he spent at Elichpur in the consolidation of his northern frontiers before proceeding to his attacks on the Vijayanagara kingdom on his south. A Brāhman captured in an earlier Vijayanagara campaign who was received into Islam under the name Fath Allāh was sent for service under the governor of Berar; later, under the Bahmanī minister Maḥmūd Gāwān, this Fath Allāh, with the title Imād al-Mulk, was himself made governor in 876/1471. The increasing loss of power by the Bahmani sultāns to their Barīdī ministers in the capital, Bidar, had led Fatḥ Allāh to

\footnotetext{
* “Gāwilgaŕh,” EI, II, 981.
} 
prepare against possible opposition by strengthening the defences of Gawilgarh in 893/1488 (inscription on Fath Darwāza), from which time also dates the rebuilding of the Jāmi' Masjid "with the old stones" and Fath Allah's use of the Vijayanagara emblems on the gates (see below). Two years later Fath Allāh assumed independence with headquarters at Elichpur and the fortresses of Gawilgarh and Narnala as his strongholds, and these remained 'Imād Shāhī possessions until the extinction of the dynasty in 982/1574 when Berar became a province of the Niz̄ām Shāhī dynasty of Ahmadnagar. After the cession of Berar to the Mughals in 1004/1596 Gawilgarh was still held by amirs of Ahmadnagar, and Akbar's son Prince Murād, reluctant to besiege it, made Balapur his principal stronghold; two years later, however, it fell to Abu'l-Fazl. The description of the süba of Berar was added to the $\bar{A}^{\prime} \bar{\imath} n-i$ Akbari immediately after the cession of Berar, obviously before the Mughals had had time to reorganize the province, and thus the place given to Gawilgarh as the largest and richest of the thirteen sarkārs must reflect the pre-Mughal administrative division. This division was substantially unchanged in the great scheme of reorganization of the Deccan provinces under Aurangzīb as viceroy in 1046/1636. In the Marāthà troubles in the Deccan in the early 18th century the province was held together by Āṣaf Jāh Niẓām al-Mulk, but on his absence in Dehli in 1151/1738 Berar with its great fortresses of Gawilgarh and Narnala was taken by the Bhōnslē Marāthās. In 1803 Gawilgarh fell to Wellesley, but was retained by the Bhōnslē in the treaty which followed; in 1822, however, it was restored to the Nizām. In 1853 it was assigned to the East India Company, and the fortifications were dismantled five years later.

\section{Monuments}

Much of the walling of the fort still remains, with gates and bastions. One fine tall bastion on the west wall, the Burj-i Bahrām, gives its date of repair (985/1577 by chronogram) by Bahrām Khān, governor of Gawilgarh under the Nizāam Shāhīs at a time when it was expected that Akbar's forces would advance. The Delhi Darwāza is most interesting for its sculptured symbols: the lions with elephants beneath their paws, level with the top of the arch, are devices of the Gond kings, but the two-headed eagles holding elephants in each beak, which lie over the lions, are the gandabherunda symbols of the Vijayanagara empire; this is the northern gate, which leads to the outer fort built in the 18th 
century by the Marāthā Bhōnslēs of Nagpur. The Jāmi' Masjid stands on the highest point within the fort, and in its present form doubtless represents the rebuilding by Fath Allāh recorded in the inscription on the Fath (south-west) Darwāza; the western lìwān was three bays deep behind the seven-arched façade, on which was some blue tile decoration in addition to fine stonework, and bore a rich chhajja on carved brackets; the mihräb wall has fallen. The most interesting feature, characteristic of the local style, is the pylon standing at each end of the lìwān façade, which bears not a minnār as in the other Deccan styles but a square chhatr $\bar{\imath}$ with projecting eaves, rich brackets, and $j \bar{a} t \bar{\imath}$ screens in each side. A large walled șahn stands in front of the tīwann, with a great eastern gateway. To the north-east of the great mosque stands a smaller unnamed mosque, similar but supported on octagonal columns. Few other buildings remain.

\section{GULBARGA*}

This city in northern Karnataka formed part of the domains of the Kākatîyas of Warangal before the Islamic conquest. It was annexed for the Delhi Sultanate by Ulugh Khān, the future Muhammad b. Tughluq, early in the 14th century, to pass first to the Bahmanī dynasty on its establishment in 848/1347, whose first capital it became under the name Ahsanabad. It fell to the 'Ādil Shāhīs of Bijapur in 909/1504, and although it was recovered by Amīr Barīd ten years later it was soon retaken by the 'Ādil Shāhīs; they held it until 1067/1657, when Mīr Jumla besieged it and captured it for the Mughals.

\section{Monuments}

The fortifications of Gulbarga are well preserved, with double walls $16 \mathrm{~m}$. thick, surrounded by a moat often $30 \mathrm{~m}$. wide, well provided with bastions - many with barbettes added later for the use of artillery - and hornworks, large and compound crenellations, machicolations and bartizans. The one major structure standing intact within the walls is the Jāmi` Masjid, built in 769/1367 by a hereditary Persian architect, Rafî̀

\footnotetext{
* "Bahmanīs," EI, I, 925; “Gulbargā,” EI, II, 1135.
} 
b. Shams b. Manșūr Pazvīnī (inscr., Haig, EIM 1907-8, 2), of a type unknown elsewhere in India, without open șahn but completely roofed over forming a pillared hall whose only illumination comes from the open side aisles and the clerestory of the central dome. The side aisles are characterised by their very wide span with unusually low imposts, an arch pattern used elsewhere in Gulbarga. Two mosques of nearly the same period at Delhi are partially covered; but this type was not imitated, presumably since the liw $\bar{a} n$ and minbar were obstructed from the view of most of the congregation.

The other Bahmanī monuments at Gulbarga are the two groups of tombs. The first, near the north-west gate of the fort, includes those of 'Alā' al-Dīn (759/1358), Muhammad I, to whom the Shāh Bāzār Masjid, an unpretentious building in the contemporary Tughluq style of Delhi, is attributed (776/1375), and Muhammad II (799/1397); the first two of these show the battering walls and weak semicircular dome of the Delhi Tughluq style; that of Muhammad II shows a similar dome, stilted below the haunch, to that of the Jāmi` Masjid. To the east of the city is the Haft Gunbad, including the tombs of Mujāhid and Dā'ūd c. 781/1380, Ghiyāth al-Dīn (c. 799/1397) and Fìrūz (c. 823/1420); some of these are two adjacent domed chambers on a single plinth. That of Ghiyāth al-Dīn shows some Hindu influence in the mihra $r \bar{b}$, and that of Fìrūz in the carved polished black stone exterior pilasters, the dripstones and brackets; the interior of the latter is quasiPersian in its paint and plaster decoration similar to the contemporary Sayyid and Lōdī tombs at Delhi. Of other buildings, the dargāh of Banda Nawāz (Rauza-i Buzurg), c. 816/1413, shows the characteristic wide arch with low imposts.

Additional monuments of Gulbarga include: Qalandhar Khān's mosque (ARADHS, 1925-6, 7 ff., Pls. IIa, Xb), built by a Bahman̄i governor after the transfer of the capital to Bidar; the mosque of Afzal Khān, an 'Ādil Shāhī general of the late 16th century (Mīrzā Ibrāhīm, Basâtàn-i Salātīn, $130 \mathrm{ff}$ ), which stands in the court of the dargāh of Gēsū Darāz, in the later stone Bijapur style, similar to the mosque of Malika Jahān at Bijapur, with hanging stone chains below the cornice (ARADHS, 1925-6, 8, Pls. IIb, XIa); the Langar mosque, early Bahmanī or possibly pre-Bahman̄, with a vaulted arch-shaped ceiling with wooden ribs recalling the style of the Buddhist cave-temples (ARADHS, 1936-7, 7 ff., Pl. VIa); a group of five mausolea at Holkonda, once a suburb of Gulbarga on the Homnabad road, similar to those of the Haft Gunbad (ARADHS, 1934-5, 1); the mosque and dargāh of Hazrat 
Kamāl Mujarrad (ibid., 5-6 and Pls. IIIa and b); the tomb of Chānd Bībī, of Nizāām Shāhī style (ibid., 6, Pls. IVa and b).

\section{HАMPI*}

Hampi is the name now commonly given to the ruins of the capital city of the Vijayanagara, empire, on the right bank of the Tungabhadra river, $60 \mathrm{~km}$. north-west of Bellary. The name seems to be derived from the prominent temple to Pampāpati (Kannada $h<$ Old Kann. $p$ ) in the $b \bar{a} z \bar{a} r$ area.

The Vijayanagara empire is of importance for the Muslim world not only as an active Hindu power which defied its Muslim neighbours for over two centuries, but also for the evidence it offers of the progressive synthesis of certain aspects of Hindu and Muslim cultures from the 14 th to the 16th centuries; this article is concerned with that synthesis as expressed in its buildings.

Most of the buildings of Vijayanagara are characteristically Hindu works in the late Hoysala style; but in some the Muslim influence is apparent, especially where the building concerned is (presumably) one built for the Muslim community or by a section of it. It is known that the ruler Devarāya I (A.D. 1406-22) had many Muslim mercenaries in his service: the first of his line to appreciate the advantages of cavalry, he had imported many horses from Arabia and Persia and enlisted trained troopers to ride them; and reference is made also to the 'Turkish' bowmen he attracted by liberal grants of cash and land (the adjective is perhaps not to be taken literally, as turaka, turashka in nonMuslim Indian texts frequently means no more than 'Muslim'). They are no doubt responsible for reconstructions in the walls and gates of the citadel of Hampi: thus, the northern gate is of the typical Hindu beam-and-bracket construction, but the remains of the turret above it show arches and parapets of the same general shape as exhibited in the Bahmanī buildings at Gulbarga; the southern gateway, one of the main entrances to the city, shows a tall domed structure supported on four open arched sides, similar to the late Bahmanī and Barīd Shāhī tombs at Bidar. Within the citadel is a large high-walled enclosure generally referred to as the zanana; the accounts of travellers to the

\footnotetext{
* "Hampi," EI, III, 147-8.
} 
Vijayanagara court suggest that the kings did indeed keep their women in seclusion - a practice which was known in early Hinduism but seems to have been most freely adopted by Hindus as a direct imitation of Muslim practice - but that they were allowed to watch spectacles taking place in the city. The so-called "watch towers" on the walls of the enclosure appear to have been built for the pleasure of the ladies of the zanāna, a purpose similar to that seen in the Mughal palaces; these towers, one square and one octagonal, have arched openings on all their faces and are thus strikingly unlike any other Hindu work in the sub-continent, although the synthesis of the Hindu and Muslim styles appears here in that the roofs are of the stepped pattern which characterizes the temple roof (sikhara). Within the enclosure stands the finest and most complete of the mixed-style buildings, known as the Lotus Mahall; this is an open pavilion on the ground floor, with massive piers and foliated arches showing a triple recession of planes of the intrados which recalls the style of the Lōdī mosques of Delhi. The upper storey is provided with numerous small arched windows in each face, originally equipped with wooden shutters, and is separated from the ground storey by a deep eaves roof on corbelled brackets very similar in effect to the deep eaves of the Bijapur buildings. The roof, however, is of the Hindu pyramidal stepped variety. This appears to be a late building (c.983/1575?).

Outside the zanana enclosure is a long oblong building with eleven tall arched openings alternating with walls of blind arches, generally known as the 'elephant stables', but which E.B. Havell (Indian architecture..., London 1927, specially 185-92) takes to be the mosque built by Devarāya II (A.D. 1422-46) for his Muslim troops. The arched chambers are domed, and the central chamber is surmounted by a square turret, probably originally crowned by a stepped tower of the Hindu pattern, approached by steps from within. However, since the building faces west not east, as would be required in a mosque, this identification can be discounted [editor]. Another structure identified by A.H. Longhurst (Hampi ruins described and illustrated, Madras 1917) as 'Devarāya's mosque' is that in the 'army commander's enclosure'; but this building faces due north (the qibla here being slightly north of west) and the identification also may be rejected.

Near the 'elephant stables' is an oblong arcaded building called a 'guard-room' by Longhurst and 'Rām Rāj's treasury' by Havell; it has also been known as the 'concert hall'. This shows the best use of the structural arch in the Hampi buildings: foliated arches with radiating 
brick voussoirs, supported on slender columns; the roof is incomplete. Its purpose cannot now be known, but it obviously reflects work by Muslim craftsmen.

Other buildings of Muslim style at Hampi include some of the constructions associated with the elaborate irrigation system, the relation of which with the irrigation systems of the Muslim cities of Bidar and Bijapur has not yet been ascertained. These include two baths - the hammām was another Muslim institution borrowed by these Hindu dynasties - and an octagonal pavilion with fountains. About $1.8 \mathrm{~km}$. to the west of the citadel stand two Muslim tombs whose style resembles that of the early Bahmanī period at Gulborga; nothing is known of the history of these tombs.

That the synthesized tradition of the Hampi buildings endured after the conquest of Vijayanagara by the Deccan Muslim confederacy at Talikota in $972 / 1565$ is shown by the palace of the last dynasty built twenty years after the conquest at their new capital of Chandragiri in southern Andhra Pradesh, some $370 \mathrm{~km}$. south-east of Hampi. This is a three-storeyed building with a façade $45 \mathrm{~m}$. wide, each storey showing a range of pointed arches; inside there are excellent pillared halls, the upper one of intersecting arches roofed by shallow domes (see R.F. Chisholm, The old palace of Chandragini, in IA, xii (1883), 295-6). The roof is crowned by seven pyramidal towers of the Hindu sikhara type.

\section{HANsI*}

A town situated in the Haryana, of which it was the old capital until supplanted by Hisar Firuza in 757/1356. It is known from inscriptions that it was occupied by the Tomārs and Chauhāns before the Muslim conquest, and was perhaps occupied from Kushāna times, in the 1st or 2 nd century A.D.: certainly the old fort, to the north-east of the present town, is an extensive tell representing an accumulation of many cultural layers. Hansi was already a major stronghold when Mas' $\bar{u} d$, son of Mahmūd of Ghazni, stormed this "virgin fortress" in the winter of 429/1037-8 (Abu 'l-Faḍl Bayhaḳī, Ta'rīkh-i Mas'üdī, Tehran 1324/1945, 533-4; Eng. tr. Elliot and Dowson, History of India ..., ii, 140), capturing

\footnotetext{
* "Hānsī," EI, III, 167-8.
} 
it at his second attempt. From that time Hansi became an important forward position in the Ghaznavids' Indian province, and we read of Mas' ūd's second son, Majdūd, who had been appointed governor of that province, spending the winter of 433/1041-2 at Hansi waiting his chance to launch an attack on Delhi. Two years later, however, the Delhi $r \bar{a} j \bar{a}$ Mahīpāl recaptured Hansi, and it was strengthened by him and subsequent builders. Towards the end of the next century it was enlarged and further strengthened by Prithvīrāja as a bulwark against the Ghūri forces; but, after the defeat of the Hindu forces at Tarawari by Muhammad b. Sām, Hansi also surrendered (588/1192). At the end of that year a Chauhān army invaded Haryana, compelling the Muslim governor Nușrat al-Dīn to take refuge in the fort; but they were overcome by Quṭb al-Dīn Aybak (details incorrect in Wolseley Haig, CHI, iii, 41, cf. Hodivala, Studies in Indo-Muslim history, i, Bombay 1939, 179-80). Within a few months Aybak had taken Delhi, and made it the headquarters of Muslim power in India; the Muslim hold on Hansi thereafter remained secure.

Hansi frequently figures in the chronicles of the Delhi Sultanate both as an important stronghold and as an $i q t \bar{a} \bar{a}^{`}$ of numerous officials: doubtless a convenient one for the sultān to have at his disposal, for it was far enough from Delhi to make appointment - or banishment - to it a reality, but it was sufficiently close to the power of arms at the capital to prevent a rebel from easily asserting his independence. For example, it was the $i q t \bar{a}$ ' of Ghiyāth al-Dīn Balban in about 640/1242, to which he was banished in 650/1252-3 after the conspiracy against him; when he had gathered some local support there he was sent further, to Nagaur, and Hansi was nominally given to an infant son of the king but in practice was occupied by one of Balban's opponents (Minhāj-i Sirāj Juzjānī, Tabakātti Nāṣiñ, ed. Bibl. Ind. 202; Eng. tr. Raverty, ii, 140); other princes had held this $i q t \bar{a}^{\prime}$ previously, for example Abu'lFath Mahmūd, the son of Iletmish, who died in 626/1229, held Hansi before 623/1226 (Tabakāt-i Nāsinì, 180) and there built the $\bar{\imath} d g \bar{a} h$ (no date; inscription in J. Horovitz, in EIM, 1911-12, 28 and Pls. XIX/1, 2). The prestige of Hansi declined after the foundation of Hisar Firuza by Fīrūz Shāh Tughluq in 757/1356, which took over the function of headquarters of a shiqq; in the previous reign, however, Hansi had been described by Ibn Batțūta as "an exceedingly fine, well-built and populous city". It certainly remained in operation as a stronghold for some time, for in 923/1517 Ibrāhīm Lōdī confined his brothers there to keep his kingdom secure while he was faced with a rebellion at Jaunpur. 
Hansi itself is little mentioned during Mughal times; it appears in the $\bar{A}^{\prime} \bar{\imath} n-i$ Akbari merely as a mahall in the sarkār of Hisar Firuza in the șüba of Delhi. For a period Hansi became the headquarters of the English adventurer George Thomas. Thomas is said to have re-fortified Hansi; certainly a military fort was established there by the British in 1803, and one Mīrzā Ilyās Beg was appointed nāzim of Haryana by General Ochterlony; but the country remained subject to constant raids and was for long in disorder until the British established direct rule over the region in 1818 .

\section{Monuments}

The old fort has already been mentioned; it was dismantled after the mutiny of 1857, but gateways and lengths of bastioned wall remain. The dargāh of Sayyid Shāh Ni'mat Allāh, who accompanied Muhammad b. Sām in 588/1192 and was killed at the conquest of Hansi, stands in the fort; Hindu materials were freely used in its construction, and if the date 588/1192 in the inscription of the attached mosque is correct it must be the oldest mosque in India (some doubt this; cf. Horovitz, op. cit., 19). On the west of the town stand the mosque and tomb of the "four Quṭbs", Quṭb Jamāl Dīn Hānsavī and his three successors; the shrine itself was not built until 903/1496, but in a mosque in the enclosure is a tombstone with an Arabic inscription of $1 \mathrm{Dhu}$ 'l-Ka'da $622 / 4$ November 1225, the oldest dated tombstone in India; another mosque nearby bears the date Muharram 877/June 1472; and in the same enclosure is the tomb of 'Alī Mīr Tujjār (sic; the word is used as a singular in Urdū), a disciple of Quṭb Jamāl Dīn. This is the finest building in Hansi, a square domed mausoleum with glazed tiles in inlaid patterns in the spandrels of the openings and filling the small blind arches above the level of the doors; it appears to date from the 15th century, although the local tradition assigns it to the 13th. Also to the west of the town is the $\bar{\imath} d g \bar{a} h$ already referred to. Further still is a mound, with a small mosque, called the Shahīd Ganj, traditionally supposed to be where 150,000 Muslims were slain, presumably in Mas'ūd's first unsuccessful attempt on Hansi. 


\section{HYDERABAD*}

The site of the present city of Hyderabad was selected in 997/1589 by the fifth Quṭb Shāhī dynast, Muḥammad Qulī Quṭb Shāh, on the right bank of the river Musa, a tributary of the Krishna, some 5 $\mathrm{km}$. east of the fortress of Golkonda, and at first given the name of Bhāgnagar after a Hindu dancing-girl named Bhāgmatī, one of the sultān's concubines. A city quickly grew up on this site, since there was no room for expansion in the overcrowded Golkonda where, moreover, the water-supply was inadequate. The exact date of the transfer of the seat of government from Golkonda to Hyderabad is not known, although this seems to have taken place within a dozen years of the foundation; Hyderabad was not at first fortified, Golkonda remaining as the citadel of the capital. At this time North India was in the hands of the Mughals, and envoys from Akbar were well received in 999/1591; the Quṭb Shāhī sulțān sent valuable presents to Akbar which were accepted as tribute, and his domains were left unmolested. The new city prospered, some of its finest buildings dating from this time (see below), until the intervention of the Mughal prince (later the emperor) Aurangzīb in the dispute between Mīr Jumla and 'Abd Allāh Quṭb Shāh in 1065/1655 when Hyderabad was plundered before the sultān bought peace; but the peace was uneasy, and Hyderabad again fell to the Mughals under Aurangzīb four years before the great siege of Golkonda in 1098/1687. After the conquest Hyderabad became the residence of the sübadārs of the Deccan, under the last of whom, Chīn Qilich Khān, Nizāam al-Mulk, the governor Mubariz Khān commenced the fortification of the city by a stone wall. After the important and decisive battle of Shakarkhelda in 1137/1724, by which the Nizāam alMulk crushed the plan of his deputy Mubāriz Khān to usurp power in the province, Hyderabad became the capital of the now independent Deccan province under the Nizām al-Mulk, who received the title of Āṣaf Jāh from the Mughal emperor Muhammad Shāh; the titles Nizạam al-Mulk and Āṣaf Jāh henceforth became hereditary in his family. The political history of the city thereafter is little different from that of the state.

\footnotetext{
* "Haydarābād, a. Haydarābād city," EI, III, 318-23.
} 


\section{Monuments}

The old city is surrounded by a bastioned wall, completed by the first Așaf Jāh, with thirteen gates and a number of smaller posterns. The city is connected to the northern suburbs by four bridges, the oldest of which (Purānā Pul) was built by Muhammad Qulī Quṭb Shāh in $1001 / 1593$. The same ruler was responsible for the buildings in the central focal point of the city, notably the Chār Mīnār, Chār Kamān, Chār sū kā Hauz, all around a crossing of four roads leading to the four quarters of the old city; also the Dār al-shifā', 'Āshūr-khāna, and Jāmi' Masjid. The Chār Mīnār, 'four minarets', is a triumphal archway, $30 \mathrm{~m}$. square in plan, its ground storey consisting of four great arches of $10.8 \mathrm{~m}$. span, each facing a cardinal point; above this is an arcaded triforium running round the building supported on carved corbels, with a smaller arcade and a perforated marble screen above it; at each corner stands a minaret $55.8 \mathrm{~m}$. in height from the ground level, each decorated with a double arcaded balcony at the level of the triforium supported by a continuation of the corbel course; a further single arcaded balcony encircles each shaft above roof-level (this is the characteristic feature of the Quṭb Shāhī architecture); and each minaret is topped by yet another such balcony supporting a round kiosk with an ogee dome foliated at its base in the Bijapur manner. The small rooms inside the upper storey are said to have been used for instruction by shaykhs; but, from the strictly ceremonial and royal nature of the use of this building under the Quṭb Shāhīs and Āṣaf Jāhīs, this story may be doubted. (See ARADHS, 1917-18, Pl. IIa; ibid., 1918-19, 3-4 and plans on Pls. III-IV.) The Chār Kamān, 'four bows', (ARADHS, 1918-19, 4), are four wide arches near the Chār Mīnār built over the four roads leading to the four quarters of the city, near to which stands the Chār sū kā Hauz, 'carfax cistern'; near this once stood Muhammad Qulī’s Dād Mahall, 'palace of justice', destroyed by a powder explosion in 1771 (described by the French traveller Tavernier in 1062/1652). West of this complex is the Makka Masjid, the principal mosque of the city, commenced by 'Abd Allāh Quṭb Shāh, continued by his successor Abu'lHasan, the last Quṭb Shāhī sulțān, and completed at Aurangzīb's order; the liwwan, with two large domes, is $67.5 \mathrm{~m}$. long and $54 \mathrm{~m}$. deep, standing behind a vast șahn $108 \mathrm{~m}$. square; the tombs of Niẓām 'Alī Khān and later Āṣaf Jāhīs stand in the mosque. The old remains of a contemporary hammām stand in its courtyard. In the north of the old city is the 'Āshūr-khāna, 'room of the tenth [of Muharram]', still in 
use for the Muharram ceremonies, with fine Persian faience decorating its walls. The Dār al-shifā', also built by Muhammad Qulī Quṭb Shāh, is in the north-east quarter of the city, a large building with arcaded chambers for the care of the sick, lying all round a paved quadrangle, formerly in use also as a school for the Yūnānī system of medicine; a mosque, built at the same time, stands opposite its entrance. Many other buildings of Quṭ Shāhī times stand in the city and suburbs, notably the Tolī Masjid of the time of 'Abd Allāh Quṭb Shāh (inscription in mihtrāb giving date of 1082/1671 by abjad); description in ARADHS, 1916-17, 3 ff. Pls. IIb and c, plan on Pl. IIIa; also the mosque and other buildings of the Shaykhpet suburb, see ARADHS, 1936-37, 2 ff., with an inscription of 1043/1633, cf. EIM, 1935-6, 21-2 and Pl. XIII.

Between Hyderabad and Golkonda, on the 'Uthmān Sāgar road, surmounting two small hills, are the bāradari of Tārāmatī, a Hindu concubine of Muhammad Qulī Quṭb Shāh, and the elegant but incomplete (no minarets) mosque of 'Pēmmatî', d. 1073/1662, for which see ARADHS, 1924-25, 2-4 and Pls. III-VI. Of the other Quṭb Shāhī monuments the Gosha Mahall stands north of the old city, a palace built by the last sultan with an extensive pleasure-park for the zanāna and an ornamental tank, now dry and used for football matches. The Dā'ira-yi Mīr Mu'min is a burial ground east of the city consecrated by a Shīi saint who came to Hyderabad from Karbala in the reign of 'Abd Allāh Quṭb Shāh; the cemetery, now used for Sunn̄̄s as well as Shî‘as, contains many fine tombs and gravestones, including the fine domed tomb of the Mīr himself in Quṭb Shāhī style.

There are also in and around Hyderabad many palaces and other buildings of the Āṣaf Jāh dynasty, from the Purānī Havelī of the first Nizām, the Chaumahalla palace in the centre of the city which was the principal city residence of the Nizāams, modelled on a royal palace in Tehran, the palace of Sir Salar Jung once used as a museum, but now demolished, to the late 19th century Falaknumā palace outside the city on the south-west, with a Palladian façade, Louis XIV reception hall, and other exotic features.

The city water supply depends on tanks, to which modern waterworks are now attached, excavated in former times. The Husayn Sāgar, about 2,100 hectares., lies between Hyderabad and Sikandarabād (Secunderabad), the road between the two cities running along the bund on its east; it was originally excavated by Ibrāhīm Quṭb Shāh in 983/1575 as a reservoir for Golkonda and was filled by a channel cut from the Musi. South-west of the city is the Mīr 'Ālam tank, built by French 
engineers in the Nizâm's service early in the 19th century, while the Mīr Jumla tank to the south-east, now no longer used, was constructed in $1035 / 1625$.

Of European monuments the old British Residency of 1803-8, now a women's college, and the tomb of the French soldier M. (Michel Joachim Marie) Raymond (corrupted locally to 'Mūsā Rahīmm'!), d. 25 March 1798, are worthy of notice.

\section{JALOR*}

A town in Rajasthan, some $120 \mathrm{~km}$. south of Jodhpur on the left bank of the Sukri river.

Although the troops of 'Alä' al-Dīn Khaljī had passed through Jalor on their return from the conquest of Gujarat in 696/1297, it was not then occupied by them. In Jumādā I 705/December1305, however, that sultān sent 'Ayn al-Mulk, governor of Multan, on an expedition to Jalor, Ujjayn and Chanderi; he was opposed by an army of 150,000 Hindus on his entry into Malwa, and his victory over them, which brought Ujjain, Dhar, Mandu, and Chanderi into Muslim possession, so impressed the Chauhān rāja of Jalor that he accompanied 'Ayn al-Mulk to Delhi to swear his allegiance to 'Alā' al-Dīn. Two years later this rājā's arrogance caused 'Alä' al-Dīn to attack Jalor, which was taken for Delhi by Kamāl Dīn Gurg. On the weakening of the sultanate at 'Alä' al-Dīn's death it seems to have relapsed into Chauhān possession.

At some time in the 14th century a body of Lohānī Afghāns left their adoptive province of Bihar and came to Marwar, where they entered the service of the Chauhān rāja of Jalor. On the latter's death by a trick at the hands of a neighbouring rāja in 794/1392 their leader, Malik Khurram, assisted the rāja $\bar{a}$ s widow in carrying on the government, but after disagreements between the Afghāns and the Rājpūts he established himself as ruler over the city and its fort, Songir (Sanskrit: suvarna-giri, "golden hill"), and sought through Zafar Khān, șübadār of Gujarat under the Tughluqs, a farmān from Delhi confirming his title; this was given, 796/1394. After Tīmūr's depredations in North India in 801/1399 the Jālorīs became independent rulers for a time, before later becoming feudatory to the new and powerful sultanate of Gujarat.

* “Djālor,” EI, II, 405. 
At some time in the early 16 th century the Jālorī family had added Palanpur to its dominions, and by mid-century its ruler had acquired the title of Nawwāb. By about 1110/1699 the Nawwāb moved his seat from Jalor to Palanpur, which remained an independent Muslim state until 1956.

\section{Monuments}

The fort of Jalor was built by the Paramāra Rājpūts, and remained substantially unchanged under Muslim rule except for the modification of its perimeter wall for artillery. The oldest monument is the mosque in the city, built from temple spoil probably at the time of 'Alā' al-Dīn, $56.4 \mathrm{~m}$. square, with cloisters of three arcades on north, south, and east, broken by doorways, and a deeper three-domed liwe latter is faced with a screen wall of later date, probably of the time of Muzaffar II of Gujarat (917-32/1511-26); an inscription including the name of Muhammad b. Tughluq stands over the north door, implying an extension or restoration in his time. The arcades have been enriched by the addition of graceful and delicate stone lattice screens of the middle Gujarati period. Known as the Tōpkhāna Masjid, it was for long used as an arsenal. A smaller mosque stands in the fort; although said by Erskine (Rajputana Gazetteer, iii A, 1909, 189 ff.) to have been built by 'Alä' al-Dīn's armies, it seems to be in its present form entirely a construction of the period of Mạmmūd Shāh 'Begrā' (863-917/14581511) or Muzaffar II of Gujarat, and bears an inscription of the latter.

\section{JAUNPUR*}

This city on the Gumti river in Uttar Pradesh, was founded in 760/1359 by Fīrūz Shāh Tughluq, near the ancient Manaych reduced by Maḥmūd of Ghazni in 409/1018 and renamed Zafarabad by Zafar Khān, its governor under Ghiyāth Dīn Tughluq after 721/1321. Muslim historians derive the name Jaunpur from Jauna Shāh, Muhammad b. Tughluq's title before his accession; but Jamanpur is known as a by-form of the name $($ ? connexion with Jaun = Yamuna; Skanskrit Yamunendrapura has been suggested as the etymon), and this origin cannot be regarded as established.

\footnotetext{
* "Djawnpur," EI, II, 498-9.
} 
In the confused conditions at the beginning of the reign of Nāṣir alDīn Mahmūd Tughluq the disaffected Hindus of the eastern provinces rejected all obedience to Delhi. The eunuch Malik Sarwar, Khwāja Jahān, persuaded Maḥmūd to grant him the title of Sulțān al-Sharq and send him to crush the rebellion in 796/1394; having brought under control Koyl, Etawa and Kanauj he occupied Jaunpur, and there established himself as independent ruler of a kingdom extending over Awadh, west to Koyl and east into Tirhut and Bihar; to these lands were later added the Chunar District (857/1453) and Rohilkhand (870/1466). In 884/1479 Bahlōl, the first Lōdī sultān of Delhi, defeated the last Sharqī sultān, Husayn, and established his son Bārbak as ruler over Jaunpur with permission to use the royal title and to issue coin. After Sikandar overcame his brother Bārbak as sulțān of Delhi in 894/1489 Jaunpur was absorbed in the Delhi Sultanate.

In 933/1526-7 Jaunpur was taken for his father Bābur by Humāyūn, and a governor was appointed; but the growth of the power of Sherr Khān (Shēr Shāh Sūrī) and the disaffection of the Afghān faction on the death of Junayd Birlās, the governor, compelled Humāyūn to march again on Jaunpur in 943/1536, with success; but Humāyūn's long absence from Delhi lost him his hold on the eastern provinces, and even before his great victory of Muharram 947/May 1540 Shēr Shāh was in command, with his son 'Ādil Khān installed as viceroy in Jaunpur. The importance of Jaunpur declined with the rise of Chunar, and not until the rebellion (970/1563 onwards) of 'Alī Qulī Khān, governor since 965/1558, does it again come into prominence; 'Alī's final defeat in Dhu 'l-Hijja 974/June 1567 led to Akbar's temporary residence there and the governorship of Khān-i Khānān Muhammad Mun im Khān. After the foundation of Allahabad the importance of Jaunpur waned; it passed into the possession of the Nawwābs of Awadh in the early 18th century, and into British hands in 1775.

Jaunpur was long celebrated for its learning, "the Shirāz of Hind", from its foundation by Fīrūz certainly until the time of Shēr Shāh; some of its rulers - notably Ibrāhīm and Husayn - were cultured connoisseurs of more than mere scholastic learning; Qur'ān schools still exist within the precincts of the mosques.

\section{Monuments}

The fort of Fīrūz Shāh, an irregular quadrilateral on the north bank of the Gumti, is of high stone walls built largely from local temple spoil, 
with a single gateway protected by tapering semicircular bastions; other bastions were destroyed in 1859 by the British, as were some of the internal buildings, including the palace built by Fīrūz Shāh's governor, the Chihil Sutūn (illustration in M. Kittoe, Illustrations of Indian architecture..., Calcutta 1838). The fort mosque of the same governor, Ibrāhīm Nāib Bārbak, still stands: the side lìwāns are low, trabeate, supported on rows of pillars from Hindu temples set up at random; there are many additions of later periods (see Kittoe, op. cit.); a detached min̄ār in the courtyard, some $12 \mathrm{~m}$. high, has a fine Arabic inscription giving its date as Dhu 'l-Qa'da 778/March-April 1377. A small detached pillar within the fort proclaims an edict of Așaf al-Daula of Awadh on the continuance of the daily stipend to indigent sayyids (sād $\bar{a} t b \bar{t}-n a w \bar{a})$ from the revenues of Jaunpur (1180/1766).

The Atalā mosque, whose foundations were prepared on the site of the Hindu temple to Atalā Devī by Fìrūz Shāh Tughluq, was not built until 810/1408 under Ibrāhīm Sharqī; its main feature, the central bay of the west hiwann covered by a large dome which is concealed from the courtyard by a tall pyramidal gateway resembling the Egyptian propylon, is the special characteristic of the Jaunpur style under the Sharqī sultāns. The Atalā mosque is the largest $(78.7 \mathrm{~m}$. square) and most ornate: the liwwans on north, east and south are composed of five pillared aisles in two storeys, the two outer aisles at ground level being formed into a range of pillared cells facing the streets; in the middle of each side is an archway, with a smaller propylon on the outside, and with domes over the north and south gates; a dome covers the central bay of each tiweran on the north and south of the main dome, each with its propylon facing the courtyard. Within each propylon is a large arched recess, with a fringe of stylized spearheads similar to those of the Khaljī buildings at Delhi, in which are pierced arched openings in front of the dome, and the main entrances beneath. The main propylon is $22.9 \mathrm{~m}$. high, the dome behind being only $19.5 \mathrm{~m}$. high, and 16.8 $\mathrm{m}$. wide at its base. The dome is supported on a sixteen-sided arched triforium, on corner brackets over an octagon with pierced windows, supported on squinch arches. The qibla wall is relieved on its exterior by square projections behind each dome, the corners of each supported by a tapering buttress; larger tapering buttresses support the main angles of the wall. There are no minārs, the top storeys of the propylon serving for the mu'adhdhin.

The Masjid Khāliṣ Mukhliṣ, built by two governors of Ibrāhīm, is of the same period, only the central propylon and dome and western tiwe ans 
remaining, all massive and without ornament. Of the contemporary Jhanjharī (jhanjhhar, "perforated") mosque only the screen of the central propylon remains, filled with the finest stone tracery in Jaunpur. The Lāl Darwāza ("red gate"; near the gate of a former palace) mosque in the north-west of the city, the smallest of the Jaunpur mosques, was built c. 851/1447, the sole surviving monument of the reign of Mahmūd Sharqī, has a single central dome and propylon with tall trabeate transepts, and zanāna galleries on a mezzanine floor flanking the central bay. The foundation of the Jāmi' Masjid was laid in 842/1438, but it was not finished until the reign of Husayn. The mosque stands on a raised terrace 5 to $6 \mathrm{~m}$. above street level, with a single propylon in the west liwwan, the transepts covered by fine barrel-vaults, and the façade entirely arcuate. These are the only remains of the Sharqīs standing at Jaunpur, the rest having been demolished by Sikandar Lōdī; all are of stone, largely pillaged from Hindu or Buddhist temples, and cement, the work of Hindu craftsmen. Echoes of the characteristic style of the capital occur in other places within the quondam Jaunpur kingdom, in the Arha' $\overline{1}$ Kangura Masjid at Banaras (Varanasi), and in the Jāmi ${ }^{\complement}$ Masjids at Etawa and Kanauj.

By far the most significant monument of Mughal times is the great bridge of Mun im Khān, begun 972/1564 and finished 976/1568, traversing the Gumti. Built by Afghan workmen under a Kabul architect, Afzal 'Alī, it consists of ten spans of arches - the four central ones of wider span than those at each end - the very massive piers of which carry pillared and screened pavilions at road level, partly projecting over the water on brackets; a further five spans carry the road over a smaller branch of the Gumti.

In the old town of Zafarabad, $6.5 \mathrm{~km}$. south-east of Jaunpur, is the mosque of one Shaykh Bārha, converted c. 711/1311 from Buddhist temple remains, entirely trabeate though originally with a large central arch between two piers, which was probably the prototype of the propylons of the Jaunpur mosques. There are also many tombs, the most noteworthy being those of Makhdūm Șāhib Chirāgh-i Hind (781/1389) and Sayyid Murtazā in the dargāh-i shahād, the burial ground of the martyrs who fell in the invasion of Shihāb al-Dīn Shūrī in 590/1194. 
KALPI*

Once a powerful town in Uttar Pradesh, the old town and fort of Kalpi stand on clay cliffs overlooking the river Yamuna; there is a modern town to the south-east of the old one, which has some commercial importance and where a fine quality paper is still made by hand. The town was traditionally founded by a rāja of Kanauj in the 4th century, and fell into Muslim hands in the first conquest in 593/1196. The high fort, walled on three sides and defended on the fourth side by the cliffs and river, was an important stronghold on the Dehli sultāns' line of communication along the Yamuna. In the early 15th century, after Tīmūr's devastation of Delhi, Kalpi became independent for a short time under a former governor, Muḥammad Khān b. Malikzāda Fìrūz, until in 837/1433-4 Ibrāhīm Shāh of Jaunpur sought to annex it to the Sharqī Sultanate; a counter-attack by Mubārak Shāh Sayyid of Delhi regained it, but in the following year during the Delhi-Jaunpur wars it was seized by Hūshang Shāh Ghūrī of Malwa and remained in the possession of Malwa for the next ten years. About 847/1443 it was sacked by Mahmūd of Jaunpur, but after the eventual fall of the Sharqī Sultanate to Bahlūl Lōdī, Kalpi reverted to Delhi, and Bahlūl appointed Quṭb Khān Lōdī as its governor. There were in addition several minor incidents during the 15th century in which possession of Kalpi fluctuated between Delhi, Jaunpur and Malwa. It fell into Mughal hands in 933/1527, and under Akbar served as the headquarters of a sarkār and a copper mint. After the Marāthā wars in the early 18th century Kalpi became the residence of a Marāthā governor.

\section{Monuments}

Among a number of old Muslim tombs to the west of the old town, one is outstanding, the Chaurāsī Gunbad (lit. "84 domes"; this name is obscure). This is a square, nine-domed structure in a walled courtyard, with two graves under the central dome; popular belief assigns it to a Lōdī sultân; it is possible that it may have been of a Lōdī governor, as the style of its arches and the supporting systems is consistent with a late 15th or early 16th century date; certain Jaunpuri motifs in its decoration do not necessarily vitiate this conclusion, as stonemasons

\footnotetext{
* "Kalpī," EI, IV, 513.
} 
would have had no difficulty in travelling from one area to another on the Yamuna. It is possible that the " 84 " of its name represents a date; if so 1584 V.S., about $934 / 1527-8$, would be the most likely.

\section{KALYANI*}

In the 10th and 11th centuries this fortified town of the Deccan, about $60 \mathrm{~km}$. west of Bidar, was the capital of the Late Chālukya rājass, passing later to the Yādavas of Devagiri (= Daulatabad); after the foundation of the Bahmanī dynasty at Devagiri, Kalyani was annexed as one of the strongholds on their northern borders; but there had presumably been a previous Muslim conquest of the town since an inscription is preserved of a Jāmi` Masjid by Ulugh Khān (later succeeded as Muhammad b. Tughluq) in 723/1323; and another Tughluq inscription of 734/1333 is known. The fort was rebuilt by the Bahmanis at the end of the 15th century after the introduction of gunpowder. The fort was maintained in good repair, as is evident from a series of inscriptions on its bastions, in the 16th century; these show that it was held by the Barīd Shāhīs as the successors to the Bahmanīs in Bidar until 981/1573, after which it passed to the 'Ādil Shāhīs of Bijapur. It fell to the Mughal empire, after a protracted siege by Aurangzīb, in 1067/1657, and was included in the Mughal süba of Bidar. When the Deccan became independent of the Mughals under the first Niz̄ām of Hyderabad, Kalyani was one of the possessions included. From 1178/1764 it was governed by a line of Nawwābs of Kalyani, of whom the first was Mīr Muhammad Ibrāhīm Khān, a son-in-law of Āṣaf Jāh of Hyderabad.

An architectural survey of the fort and its monuments is awaited [editor].

\section{KANAUJ**}

This town in Uttar Pradesh takes its name from the Sanskrit Kanakubja, but was known to the Arabic geographers as Qannauj, Qinnauj, the latter form used also in Hudüd al-'Álam. It has been identified, not beyond question, with Ptolemy's Kóv $\alpha \gamma o \rho \alpha-\mathrm{K} \alpha \dot{v} \alpha \gamma_{0} \zeta \alpha$; it is certainly

* "Kalyani," EI, IV, 513-4.

** "Kanawdj," EI, IV, 533-4; co-authored with M. Longworth Dames. 
referred to in the travels of Fa Hsien (A.D. 405) as a city under the Guptas, and as a capital and great Buddhist centre at the time of Hsüan Ts'ang's travels, c. A.D. 641, when under the great Harșavardhana it had become the chief town of the Panchāla country. As the capital of the Gurjara-Pratihāra dynasty (Hudūd al-'̄Alam, s.v. Jurz) it exercised strong control over North and North-west India from the Sutlej river to Bihar, bordered on the west by Sindh; and it is presumably against this "kingdom" of Kanauj rather than against the town that Muhammad b. Qāsim, the conqueror of Sindh, is alleged by the Chach-nāma to have made war. At the time of the Ghaznavid invasions of the 12th century, when North India was ruled over by numerous petty kingdoms, the Kanauj region was under the Gāhadavāla Rājpūts; together with Malwa, Kalinjar, Dahgan and Badaun, Kanauj bore the brunt of the Ghaznavid attacks (Mas'ūd Sa'd Salmān, Dì̌wān, 28, 219, 247, 262-65, 307, 397). Muslim colonies at Kanauj and these other places seem to have existed from the times of these incursions. Under the Ghürids the Gāhadavāla power was at first a formidable opponent, and Kanauj was not annexed to the early Delhi Sultanate until 595/1198-9; the hold seems to have been insecure, for it was necessary for Iletmish to attack it again later - presumably decisively, for a few years later we find his young grandson 'Alā' al-Dīn Mas'ūd appointing a cousin, Jalāl Dīn, to the governorship of Kanauj in 640/1243. Thereafter it figures frequently in the histories of Khalji and Tughluq times, doubtless on account of its strategic importance on the banks of the Ganga; Ibn Baț̣uța refers to it as well built and strongly fortified, and mentions its sugar trade. Kanauj figures as one of 23 provinces in the time of Muhammad b. Tughluq (Masālik al-Absār, Eng. tr. Spies, Aligarh 1943, 16).

Towards the end of the 14th century Kanauj was one of the centres of activity of the Hindu "rebels" against whom Malik Sarwar was despatched in 796/1394; and, in his new governorship which was soon to become the sultanate of Jaunpur, he was in charge of a region extending from Kanauj to Bihar. When the Sultanat al-sharq achieved independence from Delhi, Kanauj, as its westernmost stronghold, was often a point of contention between the sultanates of Delhi and Jaunpur, and there were many battles in its vicinity. The town was taken by Mahmūd Tughluq in 804/1401-2, who held it as his temporary capital (probably with the connivance of the Sharqī ruler) against his recalcitrant wazìr Mallū Iḳbāl Khān Lōdī; after the death of the latter it was recovered by the Sharqīs in 809/1407 (Tảrīkh-i Mubārak Shāhī, 175). It again figured in 
the Delhi-Jaunpur conflicts at the time of Bahlūl Lōdī versus Husayn Shāh Sharqī, and Sikandar Lōdī versus his brother Bārbak.

Humāyūn took Kanauj for his father Bābur in the campaigns of 932/1526, only to lose it, and his kingdom, to Shēr Shāh fourteen years later. After the Mughal restoration the history of Kanauj seems to have been largely peaceful, and the $\bar{A} ' \bar{n}-i A k b a r \bar{\imath}$ records it as the headquarters town of sarkār. In the 18th century, with the decline of the Mughal power, Kanauj was variously in the hands of the Nawwābs of Farrukhabad, the Nawwābs of Awadh, and occasionally the Marāthās.

Kanauj appears as a mint town, Kanauj urf Shargarh, under Shēr Shāh and the later Sūrīs; its name was changed by Akbar to Shahgarh, although under the later Mughals it appears as Shahabad.

\section{Monuments}

These are poorly described, although there are many tombs and shrines in the neighbourhood. The Jāmi' mosque, built by Ibrāhīm Sharqī, using much Hindu and Jain temple spoil, shows the westernmost extension of the Sharqī style.

\section{KANDAHAR*}

Kandahar in the Deccan, locally often spelt Kandhar or Kandhar to distinguish it from its illustrious Afghan namesake, is a plains fort $40 \mathrm{~km}$. south-west of Nanded. It and the surrounding ta'alluq, mainly agricultural, are known to have been part of the Bahmanī dominions, from whom it later passed to the 'Ādil Shāhīs. It seems, however, to have known previous Muslim occupation, since the main gate bears an inscription of Muhammad b. Tughluq (EIM, 1919-20, 16-7) and was presumably occupied by him on his expedition to South India.

\section{Monuments}

Kandahar fort is remarkable for its highly developed military architecture, which shows, successively from the exterior, a large glacis with a retaining wall, a covered way, a moat 2 to $3 \mathrm{~m}$. deep and 21 to $24 \mathrm{~m}$.

\footnotetext{
* “Kandahar,” EI, IV, 538.
} 
wide, a massive fausse-braye, built in large dressed masonry by Muslims out of Hindu materials, with defensive bastions at intervals, a second covered way, and the main ramparts of the enceinte with strong towers and bastions. Across the moat is a single drawbridge leading to a series of gateways, of which the first, the Jinsī or Lohābandī Darwāza, facing north, is protected with steel plates and defended by a bastion; a barbican court leads to the main gate, the Makka or Macchlī Darwāza, facing west. An inner court connects with the second covered way and leads to the third (Mānkalī) gate, flanked with high bastions, before the interior of the fort is reached. A Jāmi 'Masjid of the late Bijapuri style stands inside the final inner court. Many of the bastions of the enceinte bear guns, and some have inscriptions showing their construction by "Āqā Rūmī”, presumably a Turkish engineer, of dates near 998/1590.

\section{MAHUR*}

This small town in the extreme north of the former Hyderabad State is situated just to the south of the Penganga river, a left-bank affluent of the Godavari, where it forms the boundary between the former regions of northern Hyderabad and Berar in Central India.

In pre-Muslim times, Mahur had the shrine of Śrī-Dattātreya. In the middle years of the 14th century, the territory up to Mahur was conquered by the Deccani power of the Bahmanīs. In 857/1453 Maḥmūd I Khaljī of Malwa besieged the fortress of Mahur, but was unable to conquer it from the Bahmanīs, and in 872/1468 it was again a bone of contention between the two powers. In later times, however, it relapsed into insignificance. In British Indian times, it fell after 1905 within the Adilabad District and ta'alluq, but is now in Nanded District and Kinvat ta'alluq.

\section{Monuments}

Mahur has an important fortress, which may have been in existence in pre-Bahmani times. It stands on a steep hill $120 \mathrm{~m}$. above the valley of the Penganga, and is irregularly shaped since it occupies the edges of two adjacent spurs (the intermediate valley is converted into

\footnotetext{
* “Māhūr," EI, VI, 87; co-authored with C.E. Bosworth.
} 
a large tank through the construction of a massive connecting wall); the hill is precipitous on the east, south and west, its northern access being defended by multiple gateways. The main northern gateway (known as Chīnī Darwāza, from the panels of Bahmanī tilework on its façade) encloses a defended entry with guard rooms along each side; the qil'adār's residence is set in an upper storey.

\section{MANER*}

This former town, now no bigger than a village, $32 \mathrm{~km}$. west of Patna in Bihar, is located by the junction of the rivers Son and Ganga (it was reported to be at the junction in $1722,5 \mathrm{~km}$. south of it by 1812 , $10 \mathrm{~km}$. south by 1907); it had therefore some strategic and mercantile advantage, and was one of the earliest and most important sites of Muslim colonisation in this part of India.

By Mughal times, Maner had become the chief town of a pargana of some 80,000 bìghas in the șüba of Bihar $\left(\bar{A}^{\prime} \bar{\imath} n-i\right.$ Akbarì, tr. Jarrett, Calcutta 1891, ii, 151, 153). A copperplate grant from a Hindu king of Kanauj (ed. and tr. R. Sarma, in FBORS, ii/4 [1916], 437-40) of A.D. 1126 requires its Brāhman recipient in "Maniyāra" to pay the tax called turushka danda "Turk's duty", which seems to imply that tribute was being paid some 70 years before the Muslim conquest of North India, presumably to a Ghaznavid agent; the early date is strengthened by local tradition, which holds one grave in the great dargāh to be that of Tāj al-Dīn Khandgāh, the nephew of Mạmmūd of Ghazni (local traditions in Eastern India may refer to other putative kinsmen of the Ghaznavid rulers; but other early 12th century Sanskrit inscriptions also mention the turushka-dana, and references in Bayhakī point to sporadic trans-Gangetic Muslim settlement; see K.A. Nizami, Some aspects of religion and politics in India during the thirteenth century, Bombay etc. 1965, 76 ff.). The consolidation of Islam is, however, thus explained: a Yemeni saint Mu'min 'Ārif (still of great local repute) had settled in Maner, but was harassed by the local $r \bar{a} j \bar{a}$; he went back to Medina and returned with a raiding party led by Hazrat Tāj Faqīh, which defeated the local $r \bar{a} j \bar{a}$ in a pitched battle, destroyed the temple (chronogram, shud dinn-i Muhammad qaw $=576 / 1180$ ) and dismantled the riverside fort. Many

* "Manēr," EI, VI, 409-10. 
"shahìds' graves" in Maner are said to date from this time. Tāj Faqīh returned to Medina, leaving his kinsmen to rule Maner; but the rule seems to have been a spiritual one, for his grandson Shaykh Yahyā Manērī, d. 690/1291 (chronogram: makhdūm!), was the most celebrated saint of Bihar, progenitor of a distinguished line of local saints, whose shrine (in the Barī Dargāh; see below) was visited by Sikandar Lōdī, Bābur, Humāyūn and Akbar, though his fame has been eclipsed by (and sometimes conflated with) that of his son Sharaf Dīn Ahmad Manērī of Bihar Sharif, murid of Najīb al-Dīn Firdausī. Eighth in descent from Shaykh Yaḥyā was Abū Yazīd, commonly known as Makhdūm Shāh Daulat, d. 1017/1608-9, whose tomb (the Chōtī Dargāh) is the finest Muslim building in Bihar.

\section{Monuments}

The khānqāh forms a complex of buildings disposed around a vast rectangular tank (hauz), its stepped masonry sides equipped centrally with ghāts and bäradarīs, drawing its water from the river Son by a subterranean channel. The tank is said to have been rebuilt in stone at the same time as the Barī and Chōtī Dargāhs were erected in the early 17th century by Ibrāhīm Khān Kākar (not by Ibrāhīm Khān Fatḥ Jang, șūbadār of Bihār 1023-5/1615-17, as P. Horn, Muhammaden inscriptions from Bengal, EI, iii (1894), 280-96, and others assert). The Barī ("great") Dargāh west of the tank, on the site of the temple mound, is great in sanctity rather than magnificence. It consists of a great boundary wall enclosing a graveyard and a small mosque, standing to the west of a railed platform containing the simple open grave of Shaykh Yahyā (inscription of Ibrāhīm Khān Kākar, 1014/1605-6); also odd stone pillars, and a mutilated statue at the entrance presumably from the old temple. The Chōtī ('small') Dargāh is a high square platform in a fortress-like brick enclosure north of the tank, on which stands the square sandstone mausoleum of Makhdūm Shāh Daulat (inscription with decease chronogram 1017/1608-9, and two construction chronograms 1025/1616), a superb specimen of provincial Mughal architecture. The central square chamber is domed, with lower and upper verandahs (fine carved ceilings: floral, geometric and Qur'ānic designs) running round all sides, each corner formed into a square room with arched openings below and an open domed chhatri of similar size above. The lower verandah and the chhatris are built on the beam-and-bracket principle, and heavy stone corbels support both the lower and upper 
chhajj $\bar{a}$, contrasting with the arches of the tomb chamber which also has finely carved stone screen openings. A local tradition asserts that the stone was brought from Gujarat; certainly, features of Gujarati tomb design are apparent here. West of the mausoleum is a small mosque with curvilinear roof, centrally situated between stone verandahs running along the entire western wall of the enclosure; inscription dated 1028/1619, quoting Qur'ān, III, 97-8. An underground chamber in the south-west corner is identified as the chilla of Shāh Daulat. A fine entrance gate, in a more conventional Mughal style, bears two chronograms of 1022/1614-15 and 1032/1622-3. Other minor buildings around the tank are in grave disrepair.

The earliest inscription of Maner, 798/1395-6, records the reconstruction of an older mosque, now disappeared. The Jāmi ' Masjid of Maner, itself undistinguished, bears two records of renovations, of 1103/1691-2 and 1283/1866 (the last on a marble slab carved in Medina), both mosques thus testifying to a vigorous Muslim population over the centuries; but the grounds around the Maner tank are also the scene of a doubtfully Islamic fair on the urs of Ghāzī Miyān.

\section{MATHuRA*}

This Indian city (previously spelt as "Muttra") on the right bank of the Yamuna river between Delhi and Agra is of considerable antiquity and of high reputation as a place of high religious sanctity for Hindus and, formerly, for Jains and Buddhists also; it was already a place of some renown when it became the eastern of the two Kushāna capitals.

Surprisingly, Mathura is not mentioned in the Hudüd al-'alam, and only

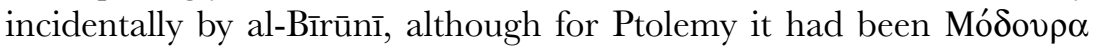

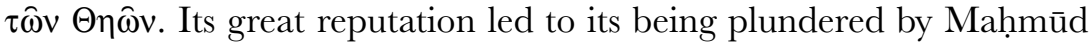
of Ghazni in 408/1018 and by many later Muslim rulers, more in an excess of iconoclastic zeal than in a settlement of the district; notably by Sikandar Lōdī c. 905/1500, who is reported to have destroyed many idols and to have prohibited head-shaving and ritual bathing. Some temples were allowed to be built in the tolerant reign of Akbar (the temple of Govind Dēva at nearby Vrindaban, erected by Mān Singh, even shows architectural borrowings from Mughal architecture); but

* "Mathurā," EI, VI, 839. 
Shāhjahān in 1046/1636-7 appointed a governor to "extirpate idolatry", Aurangzīb some 30 years later destroyed its finest temple and built a mosque on top of it, and Aḥmad Shāh Durrānī in 1170/1757 not only plundered the temples but butchered a large group of pilgrims. Otherwise, the city saw little of Islam, the Mēwātīs, in whose territories it lay, not being renowned for their orthodoxy.

\section{Monuments}

A Jāmi' Masjid, built in 1071/1660-1 (inscr. chronogram) by 'Abd al-Nabī, a governor under Aurangzīb, is an excellent building for its period, with fine inlay in encaustic tilework, four tall minārs, and two side pavilions with the curved-cornice "Bengali" roof flanking the courtyard which stands $4 \mathrm{~m}$. above road level; Aurangzīb's own mosque is rather effete.

\section{MeERUT*}

The city of Meerut (Mĩrath) is of considerable antiquity. It was the site of a pillar of Ashoka, one of the two taken by Fīrūz Shāh Tughluq to Delhi, and within the city are Buddhist remains dating from the 3rd century B.C.; but since these are not mentioned by the Chinese travellers Fa-hsien (4th century A.D.) and Hsüan-tsang (7th century), there had probably been an early decay of Buddhist influence. A strong fort was built here in the 11th century by the Hindu ruler of Baran (= Bulandshahr), originally surrounded by a moat and a wall with eight gates (other gates were added in Muslim times); this was the fort captured from the Dor Rājpūts by Quṭb al-Dīn Aybak in 588/1192, using this and the fort of Baran from which to overthrow the Gahādavāla Rājpūts and make his assault on Delhi. Meerut remained in Muslim control through the early sultanate of Delhi (the names of several iqța $d \bar{a} r s$ are recorded by the chroniclers Minhāj, 'Ișāmī, and Baranī); in 727/1326-7 the forces of the Mongol invader Tarmashīrin were defeated at Meerut, but by $802 / 1399$ the city had been sacked and destroyed by Tīmūr.

\footnotetext{
* "Mīrath,” EI, VII, 113.
} 
There seems to have been some return to prosperity in Mughal times: the fort is mentioned in the $\bar{A}^{\prime} \bar{\imath} n-i$ Akbari . Meerut was briefly a copper mint under Akbar, and the Mughal emperors seem to have taken some interest in the buildings (repair of Jāmi' Masjid by Humāyūn; a couple of dargāhs, of Abū Yār Muhammad Khān (1039/1629) and Abū Muhammad Khān (1099/1688); the maqbara of Shāh Pīr of 1038/1628 erected by the order of Nūr Jahān, a red sandstone building with the characteristic wide four-centred Mughal arch (photograph in Meerut gazetteer, UP Govt., Lucknow 1963); the presence of a karbalā, c. 1009/1600, and two imāmbārās, indicates that some Shīa settlement had taken place. In the early 18th century, with the rise of the Sayyid brothers as kingmakers, there were many grants of land made in the Meerut area, and there was some industry in the form of indigo-processing and in the manufacture of the fine lambswool sānsla blankets; but after the invasion of Nādir Shāh in 1152/1739 the land fell into anarchy, and by the early years of the 19th century Meerut was ruinous and depopulated. The considerable gain in British prestige after Lord Lake's success in the battle of Delhi, 1803, led to the establishment of an extensive military cantonment at Meerut, whereby the city regained its prosperity to the extent of securing a reputation as one of the best laid-out towns in Upper India. The events of 1857, when the mutiny of the Bengal army started in Meerut, led to the final loss of all power by the ruling Mughal house

\section{Monuments}

Apart from those mentioned above, there are a few Muslim monuments, some of considerable antiquity, which have been but poorly described, and no photographs are available. The Jāmi 'Masjid, on the site of a former Buddhist temple, is said to have been erected in 410/1019 by Hasan Mahdī, a wazìr of Mahmūd of Ghazni; the dargāh of Makhdūm Shāh Wilāyat in the reign of Shihāb al-Dīn (= Mu izz al-Dīn) Ghūrī; and the maqbara of Sālār Mas'ūdī by Quṭb al-Dīn Aybak at the end of the 12th century (since he was killed in battle at Bharuch in 425/1034, and has cenotaphs in other Indian towns, this maqbara may refer rather to his cult as a folk-divinity). The gazetteers mention some "scores of other temples and mosques, of no particular interest", but no-one seems to have looked at them to see: although only some $65 \mathrm{~km}$. from Delhi, Meerut has been badly served by archaeologists. 
Other buildings within Meerut District include the Begam Samrū's palace (Dilkusha Kōthī) of 1822, at Sardhana; on a (pre-Muslim) mound south of the town of Barnawa are the dargāhs of Badr al-Dīn Shāh and Shāh 'Alā' al-Dīn (undescribed) and the maqbara of Pīr Sarwār, Persian inscr. dated 948/1541-2.

\section{MudGAL*}

This ancient fort in Karnataka state, together with Raichur, formed a principal defence of the Raichur $d \bar{o} \bar{a} b$, between the rivers Krishna and Tungabhadra, that continuous bone of contention between the Hindu kingdom of Vijayanagara and the Deccan Sultanates. The date of its foundation is unknown, but it seems to have passed from the possession of the Yãdava rulers of Devagiri (Daulatabad) to the Kākatīya kings of Warangal, and from the appearance of the cyclopean masonry of parts of the outer wall, it could well have been established under the former. Mudgal came first to the attention of a Muslim sultanate after the conquest of Devagiri (694/1295), when Malik Kāfūr captured and garrisoned both Mudgal and Raichur when on his way to attack the Kākatīya capital of Warangal; but there are no records of how long Muslim sway was then maintained. After the establishment of the Bahmanī Sultanate in Gulbarga, Mudgal frequently changed hands between that sultanate and Vijayanagara; thus under 'Alä' al-Dīn Hasan Bahman Shāh, the founder of the sultanate, it formed, with Raichur, part of the Aḥsanābād-Gulbargā taraf under the able wazīr Sayf al-Dīn Ghūrī; it was lost for a time to the Vijayanagara ruler Bukka I, but recaptured in the wars of 767/1366 when the Bahmanīs used cannon for the first time, and it was presumably about this time that the defences of the fort were adapted for artillery.

The beginning of the reign of Dēvarāya I in Vijayanagara, 808/1406, saw a renewal of hostilities brought about by the notorious "war of the goldsmith's daughter", an accomplished young lady whom the rāja coveted; the Bahmanīs under Fīrūz were victorious, Dēvarāya had to pay a large indemnity, marry a daughter to Fīrūz, and cede the fortress of Bankapur, in the west of the $d \bar{o} \bar{a} b$, as a bridal gift. But the continual

* "Mudgal," EI, VII, 289. 
withholding of tribute from Vijayanagara led to more fighting in the $d \bar{o} \bar{a} b$ when Dēvarāya II, anxious to enlarge his dominions, again took Mudgal in $c .846 / 1442-3$, only to lose it again shortly afterwards.

The decline of the Bahmanī Sultanate under Shihāb al-Dīn Mạ̣mūd, with the incipient Barīd-Shāhī and 'Ādil-Shāhī powers now gaining in strength, left Mudgal under 'Ādil-Shāhī control, again with constant harrying from Vijayanagara; but the $d \bar{o}$ 'a $b$ did not come finally under Muslim control until the confederacy of the four Deccan sultans crushed the Vijayanagara armies decisively at the (so-called) battle of Talikota in $972 / 1565$.

\section{Monuments}

The seven inscriptions at Mudgal are all of the 'Ādil-Shāhī period. The fort with its ponderous walls is defended by a wide moat (sometimes as much as $50 \mathrm{~m}$. in width), with a bastioned scarp, a covert way, and a heavily bastioned counterscarp with round and square towers alternating, much as in Golkonda); the towers show signs of having been rebuilt for artillery. A range of hills defends the fort to the south-west. The Fath Darwāza to the north is defended by a strong barbican (again as in Golkonda), with an inscription of 996/1588, after 'Ādil-Shāh's death, although it has been suggested that the victory commemorated is the battle of Talikota of 23 years before; a bastion inscription of 982/1574 records the conquest of Bankapur. The southern gate is interesting as showing three gateways of different periods, the inner one of beamand-bracket construction with small trefoil arches in the guards' rooms; this is of the Hindu period, and there are many Hindu sculptures in the vicinity. The middle gateway, however, is arched, and the outer gate (Kāntī Darwāza) is, as the name implies, heavily studded with iron spikes as a defence against elephants. There are several buildings in the fort, now somewhat ruined: a central mound (Balā Hiṣār) held the royal buildings, of which a roofless barradar remains; an inscription of Muhammad 'Ādil Shāh of 1053/1643 records the building of a marble palace, called Gagan (?) Mahall - the reading mahall-i khakan is presumably for gagan "sky", as in Bijapur. An 'äshür-khāna, a naubatkhāna, some powder magazines, and an early mosque constructed of plundered Hindu pillars have been identified, and water for the garrison is provided by a large $b \bar{a}$ o $l \bar{\imath}$ (Hikranī b.) in the west of the fort. 


\section{NAGAUR*}

The walled town (also spelt Nagawr and Nagor) in Rajasthan is said to have derived its name from its traditional founders, the Nāga Rājputs. In the later 12th century it was controlled by the Chauhān (Chhamāna) ruler of Delhi, Prithvīrāja III, then by the Ghūrid Mu izz al-Dīn Muhammad, although there are indications of an earlier Muslim presence before the Ghürid conquest, under the old governments of Sindh and Multan. It remained an important stronghold for the sultanate of Delhi, controlling both Sindh and southern Rajasthan until the decline of the Tughluq dynasty in the late 14th century, when it fell into the hands of Muzaffar Shāh I of Gujarat; he gave the state of Nagaur to his brother Shams Khān Dandānī, and the Dandānī dynasty lasted for over a century until Muhammad Khān Dandānī submitted to Sikandar Lōdī in 915/1509-10. After the Lōdī period it passed to Rājā Maldev of Jodhpur, who built the fort and incorporated much old Muslim building in its walls. It fell again to the Delhi Sultanate under Shēr Shāh, subsequently becoming part of the Mughal empire until its final fall; thereafter it reverted to the Mahārājā of Jodhpur.

By the 14th century Nagaur had become a centre of the Chishti Șūfì order and was already a renowned home of Muslim mysticism and scholarship, starting with Shaykh Hamīd al-Dīn Suwali Nāgaurī (d. 673/1274) (early genealogy in M. Shokoohy, Corpus Inscriptionum Iranicarum, xlix (Rajasthan 1), London 1986, 68-86, and Pls. 62a-80c). In the 16th century, it was the birthplace and early home of Shaykh Mubārak Nāgaurī (911-1001/1505-93), later influential, as was his younger son Abu 'l-Faḍl 'Allāmī, at Akbar's court as an exponent of a more liberal and eirenic view of the role of Islam in India than that held by the rigorist 'ulam $\bar{a}$ ' who opposed Akbar's religious policies (see A. Ahmad, Studies in Islamic culture in the Indian environment, Oxford 1964, 168-9; S.A.A. Rizvi, Religious and intellectual history of the Muslims in Akbar's reign, Delhi 1975, 76-103).

\section{Monuments}

Inscriptions from many of the earlier buildings, including one from the time of Muhammad b. Sām, and several of the Khaljī and Dandānī

\footnotetext{
* "Nāgawr," EI, VII, 898; co-authored with C.E. Bosworth.
} 
periods, are set into the upper walls of the fort. The oldest standing monument, and the finest, is the Buland Darwāza, also known as Darwāza-yi Tārikīn, a gateway leading to the enclosure around the shrine of Shaykh Hamīd al-Dīn. An inscription refers to its construction in $733 / 1333$, i.e. in the reign of Muhammad b. Tughluq, but this must refer to a restoration, since the style and the surface decoration are more consonant with the buildings of Shams Dīn Iletmish; a fine Qur'ānic inscription above the gateway is in a typical 13th century chancery script. The Shamsī Tālā'ō, the Shamsī 'İdgāh and the Shamsī Masjid, in earlier writers attributed to Shams Dīn Iletmish, are in fact rather of Shams Khān Dandānī. The Shamsī Masjid, large and impressive, has a western prayer-hall in the beam-and-bracket style, with five domes (the central now fallen) and two tapering corner turrets resembling those of Lōdī buildings, faced by a maqsūura-screen of five arches, similar in type to mosques of Gujarat. Other mosques of a similar period (Ek mīnār kī Masjid, Sūrī Masjid) are also trabeate, but the Akbarī Masjid of $972 / 1564-5$ is entirely arcuate, in the early Mughal style. There are many small mosques of Mughal reigns up to Aurangzīb in the various mahallas of Nagaur city.

\section{NALDURG*}

This small town and its fort, standing above the ravine of the Bori river in Maharashtra, are one of the best fortified strongholds in the Deccan. The name, which also appears as Naldrug, is derived from durg (= Sanskrit, durga, "fort").

Naldurg does not figure in the Deccan campaign of Muhammad b. Tughluq, and so probably came into Bahmanī possession after the imperial forces had withdrawn, in the late 14th century; its stone fortifications, which appear to be of Bahmanī work although elaborated later under the 'Âdil Shāhīs of Bijapur, may have replaced an earlier Hindu (? Chālukya) mud fort. Thereafter, Naldurg incurs frequent mention in the dynastic squabbles of the Deccan, lying as it does on the border of the 'Ādil Shāhī and Niz̄ām Shāhī territories of Bijapur and Ahmadnagar respectively, having later even attracted the attention of the Quṭb Shāhīs of Golkonda. Thus Muhammad Khān, the brother of

* "Naldrug," EI, VII, 943. 
'Alā' al-Dīn Aḥmad II Bahmanī, in rebellion in 840/1436, is reported to have occupied Naldurg as well as Mudgal, Raichur, and Sholapur; after the fragmentation of the old Bahmani kingdom, when Naldurg became a bone of contention between the rival sultanates, there was a war between Qāsim Barīd and Yūsuf 'Ādil Khān in 897/1492, when Qāsim was humiliated; in 914/1508 Aḥmad Niẓām Shāh unsuccessfully demanded Naldurg from Yūsuf as his price for neutrality against the rival claims of Maḥmūd Shāh Bahmanī and 'Alī Barīd. In 938/1531 Amīr Barīd had entered into an alliance with Burhān Niẓām Shāh against Ismā'îl 'Ādil Shāh and marched on Naldurg, but was defeated by Ismāi îl; Vijayanagara entered the contest when in 970/1562-3 the lands of Husayn Nizām Shāh of Ahmadnagar were invaded by Rām Rāj of Vijayanagara, now allied to 'Alī 'Âdil Shāh of Bijapur; but Rām Rāj withdrew after his camp was flooded in the rains, whereupon 'Alī 'Ādil Shāh withdrew to Naldurg and carried out some rebuilding, including a dam across the river Bori, to improve the water supply to the garrison. In 989/1581, after the death of 'Alī 'Ãdil Shāh, Murtazā Nizām Shāh attempted to recover Sholapur and Naldurg, now with the help of Ibrāhīm Quṭb Shāh of Golkonda; but the allied forces, on seeing Naldurg's great strength, moved rather to Bijapur itself; the siege of Naldurg, however, was prolonged under the next Quṭb Shāhī sulțān, Muhammad Qulī Quțb Shāh, the following year.

In 1003/1595 Ibrāhīm 'Ādil Shāh of Bijapur invaded the Nizāam Shāhī kingdom; in an ensuing battle at Naldurg Ibrāhīm Niẓām Shāh was killed. But there was now a greater danger on the horizon, and the 'Ādil Shāhī and Quṭb Shāhī,forces were allied at Naldurg against the Mughals. During the Mughals' Deccan campaign the Nizāam Shāhī Sultanate was in 1046/1636 invaded by Shāhjahān's general Shā'ista Khān, who after his success turned his attention to the 'Ādil Shāhī kingdom, conquered Naldurg and occupied the region between Sholapur and Bidar, although the Mughal success was then short-lived; in 1087/1676 the Mughal general Bahādur Khān failed in a further siege against Naldurg, although Naldurg fell to the Mughals the following year; this was of course an important possession for the Mughals in view of the growth of the hostile Mārātha power. There seems to be no record of when Naldurg finally came into the possession of the Mārāthas. 


\section{Monuments}

The fort is an imposing building, but now disfigured with mean squatters' buildings. An interesting addition to its fortifications is a multilobed circular bastion on the south wall, similar to but smaller than the one at Golkonda fort. The water-palace and other palace buildings, and the mosque, have not been adequately described or published, but an inscription in the water-palace (Pāṇ̄ Mahall) refers to the erection of a dam in 1022/1613 (EIM, 1917-18, 3). There are illustrations of the Pānī Mahall and the multi-lobed bastion in ARADHS, 1917-18, Pl. III. Besides those within the fort, there are several mosque buildings in the vicinity of Naldurg which appear to be of the late 'Âdil Shāhī style and period.

\section{NARNALA*}

This hill-fort is located in the Berar region of the Deccan (now in Maharashtra State), at the southernmost end of the Satpura hills. The fortress is presumably pre-Muslim, since Firishta (Gulshan-i Ibrähīm $\overline{)}$ ), states that it was restored and repaired by Aḥmad Shāh Bahmanī between 828-31/1425-8, and the earliest buildings there appear to be of the Bahmanī period, although later the fort passed into 'Imād Shāhī hands. Narnala played an important role in the warfare of the rulers in the Deccan of the Bahmanīds, Khāndesh sulțāns, 'Imād Shāhīs and Niz̄ām Shāhīs, being held for the latter princes 979-1005/1572-97 till its capture by the Mughals.

\section{Monuments}

The fortifications comprise three distinct but conjoined forts, with a competent and still well-preserved water supply. There are insufficient remains of the old Jāmi' Masjid to relate it now to the characteristic 'Imād Shāhī style, although there are features of the excellent main central (Mahākālī) Darwāza, of 892/1487, which seem to have determined the later mosque architecture: a central arch of fine dressed stone within a larger arch, under a pylon crowned with trefoil merlons, and

\footnotetext{
* "Narnālā," EI, VII, 965.
} 
liberally decorated with stringcourses, embossed medallions and rosettes; there are flanking chambers and galleries, with projecting balconies on corbelled brackets, and fine lattice tracery. This is an architectural achievement of a high order, and important in the development of the 'Imād Shāhī style. The other buildings (hammām, bāradarì, stables, etc.) are of less value; there is also a small mosque of the time of Aurangzīb.

\section{NARNAUL*}

This ancient town in Haryana, some $130 \mathrm{~km}$. south-west of Delhi, was probably (Ishwari Prasad, Life and times of Humayun, 95) the birthplace of Shēr Shāh, his family having been associated with the place for some time. But Narnaul has much older Islamic associations, with the inscription at the Dargāh of Shāh Wilāyat showing that the saint was living here in and before 531/1137, i.e. over 50 years before the Muslim conquest of Delhi; his dargäh shows signs of the pre-Muslim style of coffered-roof construction, familiar from such early sites as Ajmer and Bayana (description and discussion in K.V. Soundara Rajan, Islam builds in India, Delhi 1983, 89-90), and may well be contemporary with the saint. Indeed, the town could well be earlier, since the approach from a distance reveals it as an obvious tell; but unfortunately Narnaul has not been excavated. In the 18th century it was at times held by Rājput princes and the Marāthās. Its Muslim Nawwāb was involved in the Sepoy Mutiny of $1857-8$, hence the town was afterwards awarded to the loyal maharajā of Patiala.

\section{Monuments}

There is evidence of all phases of Indian Muslim building, from early Delhi Sultanate, through Khaljī, Tughluq and Lōdī, to early and late Mughal and to Mughal-inspired Rājpūt. The earlier phases are mostly to be seen in and around the dargāh complex; many Lōdī-style buildings, frustratingly but typically undated, occur not only in Narnaul itself but also sporadically all the way to Delhi (at, e.g., Rewari, Sohna and Gurgaon); the best example of the late-sultanate styles is in the tomb of Ibrāhīm Khān Sūr, which stands within the dargāh complex. Ibrāhīm

\footnotetext{
* "Nārnawl," EI, VII, 965-6.
} 
was the grandfather of Shēr Shāh, and the building of this tomb was Shēr's first preoccupation after his arrival in Delhi, having expelled Humāyūn in $947 / 1540$. It is a tall square structure in polychromatic stonework (sandstone, schist and marble), well decorated with carved and inlaid stone, the dome surrounded by a high octagonal drum with ornate polychrome guldastas and with chhatris at the four corners; the walls, with a slight batter, and the trabeate entrance doorways, continue the traditions of the Lōdī style. Other buildings show the Mughal styles at their most felicitous, with tombs and pavilions set within gardens and tanks, showing again fine stonework, such as the Jal Mahall and the tomb of Shāh Qulī Khān, the latter introducing the octagonal type. Within the town there is, among other fine buildings, a particularly fine havêtè, the Chattā Rāì Bāl Mukund Dās, with courtyards surrounded by elegant marble pillars, fountains, projecting balconies, richly bracketed eaves, and culminating in a curved-cornice baradar of the "Bengali" style introduced to North India in the time of Shāhjahān and later to be so popular in Rājpūt building.

\section{THALNER*}

Now nothing more than a large village in Dhulia District, Maharashtra, Thalner was once of importance as the site of an imposing and powerful fort overlooking a wide sweep of the Tapti river, and of the tombs of the Faruqi Khans of Khandesh. These monuments are mentioned in the standard histories and accounts of Indian Muslim buildings, but they have not hitherto been accurately described, and no deep study of them is known to exist. The account given in the old Bombay Gazetteer reveals more about the authors than the monuments.

The tombs of the Khans, with some monumental tombs of their associates and with many individuals and some grouped graves on numerous plinths, stand on open ground to the north-east of the modern village. The only other antiquities at this site are the idgah to the west of the village, and the crumbling ruins of Thalner fort, on the river bank less than $1 \mathrm{~km}$. to the south of the village. These we did not investigate in detail; but, for purposes of comparison, we visited the town of Burhanpur, the major town of Khandesh and the former Faruqi

\footnotetext{
* Unpublished field report.
} 
capital. The modern village is almost entirely Hindu now; but I had a long conversation with an elderly Muslim gentleman who recounted to me the local traditions. Since these were delivered in a mixture of Dakhni Urdu and Marathi from a mouth much hardened by pan, I may not have recorded them all accurately; but he is my source for the attributions below. We have found it more convenient, in general, to refer to the tombs and mosque-walls by numbers, arbitrarily given by ourselves since we could discover no previous system of numbering.

Tomb 1, the southernmost, is said to be that of a brother of Mubarak Khan. It is an octagon of grey trap stone formerly standing on a high platform which has now collapsed towards the west. The dome has completely fallen, as have the west and north-west walls above plinth level; and only a little of the façade of the south-west and north walls remains. The plinth does, however, reveal that the only entrances to the tomb were on the east and south. There are no inscriptions, but each wall is elaborately decorated inside and out; each face is slightly different. The relief-carved designs are complicated, but most recur in the other tombs although in less confusion. This is the only octagonal tomb in the group; no instance of a comparable tomb in either Gujarat or Malwa (the two regions alleged, in the standard histories, to have the closest affinities with Khandesh) occurs to me.

The platform on which Tomb 1 stands is continued northwards to form a common plinth for Tombs 2, 3 and 4. Tomb 2, square and of lighter stone than Tomb 1, is said to be that of Altamish Khan. The building carries a single dome; no trace is visible from the ground of corner domes, nor are there any interior indications to suggest their presence. Externally there are heavy chhajja brackets, one slab of the chhajja remaining in the west wall. Each side is composed of three arch shapes filled in with masonry of irregular shape but of good jointing (but I did not get the impression that the tomb started as an open pavilion which was later filled in; this style of construction seems to have been deliberate, and I doubt whether a simple open pavilion could have supported the massive dome). The arches rest on pillars of Hindu style, of several different patterns and not disposed symmetrically, which being of the same thickness as the walls are visible on both the exterior and the interior faces of each wall, three of such pillars appearing at each corner. The south door, the only entrance, appears to be a concrete restoration. The tomb is square inside, the west and east walls being completely plain without windows. The west wall interior is finely worked into three mihrab niches, although the position of the mikrab is 
not differentiated on the exterior. Over the window on the centre of the north wall is a finely written inscription; of the two flanking blind niches on the walls, that on the east is especially deep. At the time of our visit this tomb was being used as a residence by the nominal chowkidar of the tombs, who was absent both at our preliminary enquiry and for our subsequent visit, and we were enable to see the interior only through the courtesy of the local Sub-Inspector of Police, who had a duplicate key.

Tomb 3, the most important of the whole series, that of Miran Mubarak Khan, is also generally square on exterior plan, but with the central bay of the three on each side projecting and flanked by engaged octagonal buttresses or pilasters, which continue upwards above the level of the chhajja. On the south wall there are inscriptions around the door and on the pilasters, and fragments of a band of inscription above chhajja level and below the merlons (there is also a fragment of this band on the west wall). Owing to encroaching vegetation it was not possible to see all of the inscription; and unless the pipal seedlings that have established themselves on the roof are quickly removed the tomb and its inscriptions will suffer irreparable damage. The tall stilted dome was flanked by four corner domes, traces of which remain. The south entrance-door has an inner architrave which at top carries a square projection resembling the lalata-bimba on Hindu temple doorways; the tympanum above was formerly filled with jali work. The side bays on each face show open windows which originally had projecting sills carried on corbelled brackets and canopied above (marks on the stone show the extent of the side projections of the canopy) with hanging lotus buds. The central arches on each bay show the so-called 'spearhead fringe'.

The interior of the tomb is an octagon formed by cutting off rooms at each corner which open to the exterior by the canopied windows already mentioned. Each wall of this octagon is a great arch of the height of the hexadacagon which forms the lowest tier of the phase of transition; within these arches and in the same plane are smaller arches, larger at the corners than on the cardinal-point walls; all these are flanked by niches, the heights of which are not entirely regular. The inner floor (no graves or cenotaphs are now present) is at ground level, with a surrounding plinth on which the internal arches of the octagon, and the corner rooms, rest. There are small oblong chambers at the centre of each wall, the southern one of which forms an 
entrance porch. The dome interior is ribbed, and is well decorated by concentric bands of carving.

The tomb has an immediate superficial resemblance to the tomb of Darya Khan at Mandu; but it differs considerably from that monument in its internal arrangement and decorative motifs, and there are also many points of difference in the exteriors of the two tombs. It should be pointed out in this connection that although Mandu has been excellently served by G. Yazdani in Mandu, the city of joy, the description and the illustrations of the monuments are insufficient to permit of detailed comparisons, and deep study of the architecture of these monuments is still needed.

Tomb 4, the westernmost of the main group at Thalner, is said to be that of 'Adil Khan. This is built of a fine stone, more reddish in tone than that of its neighbours. The drum of the main dome, and the bases of the four corner engaged domes, is of a light red brick which was originally plastered over. The stone jointing of the masonry is again of excellent workmanship, although the stones are of irregular size and are not laid to regular courses. The tomb is square on plan, with its west and east walls completely unadorned on the exterior except for the chhajja; this is carried on heavy stone corbels, well carved, which support transverse lintels with further carving on their undersides (the heavy chhajja slabs have mostly fallen, and most of a chhajja structure on the west wall, a reinforced concrete restoration, has come away). Below the corbels and in vertical register with them is a row of bosses on each wall which appear to have supported an outer row of brackets; sockets cut in the undersides of the lintels seem to support this view. On the south façade there are four blind niches each surmounted by a characteristic merlon device (either three or five merlon shapes, flanked by two half merlons) which occurs also no the decoration of the other tombs. The doorway, as on Tomb 3, is on the south; it has a peculiar lalata-bimba boss, as in that tomb, but in this case bears a simple 'Allah motif. The interior of this tomb is square, with little decoration or variation except for deep cells in each side in the thickness of the walls. The engaged corner domes are a characteristic feature of the Muslim architecture of Malwa; but other Malwa characteristics do not appear in this tomb. The treatment of the chajja brackets in double rows is more suggestive of the eaves supports in the later stages of the buildings of Bijapur.

Tomb 5, the attribution of which I was unable to ascertain, is small, and has a tall stilted dome haunched abruptly. Where the larger tombs 
have corner domes, this has merely four corner guldastas of simple shape standing in the angles of the flat roof.

Tomb 6, called locally the tomb of Bibi Faruqi, differs from the tombs of the main group in being of brick with a stucco surface. The single dome is shallow. The blind merlons which form a false parapet (actually below the level of the flat roof) meet at the corners of the tomb in fluted guldatasa, recalling those of the Bahmani buildings at Bidar. Below these blind merlons is a stringcourse of brick-on-angle, with the re-entrance angles rounded off into a curve with an infilling of stucco. The same decorative pattern recurs inside the tomb in the corner pendentives of the phase of transition. The single entrance is on the south, its recessive curve also recalling the early Bahmani buildings; there are pierced openings centrally on the other three walls (i.e., there is no mikrab), flanked with blind niches.

Tomb 7, a small square stone building, heavily whitewashed, contains a single marble grave - the finest cenotaph in Thalner - said to be that of Hazrat Shah Raje, a disciple of 'Ayn al-Mulk of Delhi. There is no chhajja or parapet, but a row of blind merlons appears at the top of the cube. The dome is more or less hemispherical, not stilted, and is the only one at Thalner still to carry an amalaka and kalasa finial.

Tomb 8 is a ruined building of larger size, said to be that of the Wazir al-a'zam Muhi al-Din. The dome has fallen, damaging the single grave below (this is to the east of the central axis and therefore is presumably a subsidiary grave). Most of the external ashlar facing has also fallen, although what remains is of superb quality with intricate decoration. The internal plan of this tomb is similar to that of Tomb 3, and most of the internal ashlar remains. The interior arches and niches are of slightly varied design. There are corner chambers, as in Tomb 3 , above which were originally corner domes.

Tomb 9 is also small, and is attributed to the darogha Amin al-Din. The exterior, of dark trap stone, has an encircling stringcourse at the level of the haunch of the door arch, and heavy brackets at eaves level which have carried a chhajja. There is a single door on the south side, with window openings on the other three sides (again, there is no mihrab) whose haunches are cut by the stringcourse.

Tomb 10, said to be that of Bibi Areza, stands remote from the main group near Mosque-wall 4, and is on a high plinth. A small cubical structure surmounted with a tall dome, it is of brick with a facing of stucco, with a single entrance on the south; there are window openings on the other three sides, with no mikrab. Flanking the openings on the 
exterior are narrow engrailed arched niches of a shape usually associated with late Mughal buildings. The interior is a simple square; there are traces of colour decoration in the stucco of the dado, below the roof, and in the roof arches. Below a band of a coloured pattern of crosses is a highly polished fillet of cunam with some graffiti in good nastaliq in black ink, somewhat obscured by whitewash. The stucco cenotaph is dilapidated.

There is no mosque on the site (I was told that a small mosque in the village, which I did not see, was quite recent); the ritual cihal and urs observances for those buried in the tombs and in the many graves, grouped and individual, which cover the site, would have been provided for by the open mosque-walls, of which there are four in a more or less ruinous condition. They are simply short massive walls running approximately north-south, with a niche on the east side whose function is to indicate the qibla to a worshipper facing west; corresponding to the niche is a buttress on the western side. Mosque-walls 1, 2 and 4 are in poor repair (Mosque-wall 2 seems likely to collapse soon), although the corner guldastas of these are interesting in that they resemble the two-staged guldastas of the smaller mosques and idgah of Burhanpur. Mosque-wall 3, however, is a much more elaborate structure of seven bays, with much looted Hindu material built into it as pillars and pillar bases. There are few graves to the east of Mosque-wall 1, which may imply that the graveyard had once a greater eastward extent. Only Mosque-wall 3 was considered with detailed survey, although the positions of the others were accurately recorded on the site plan. No attempt was made to record the positions of the individual graves.

The Faruqi idgah, to the west of the village, was not surveyed; nor was the ruinous fort to the south of the village. This has suffered much from floods and erosion, for it stands very near the north bank of the river Tapti. Part of the west wall, up to below the level of the battlements, remains, and parts of large circular buttress towers are still visible. The fort contains no standing buildings, although there are traces of the walls of a mosque and hauz and of a hammam. At the top of the mound are the ugly tombs of two British officers, uninscribed, who are said to have been killed in 1818 .

This preliminary study has revealed that the tomb buildings of Thalner are of great variety, of materials, construction and decoration alike; almost the only unifying feature, and that not common to the entire group, is the 'N-plus-two-halves' merlon pattern over niches referred to above. There are features which recall certain elements in 
the buildings of Malwa, of the Bahmanis of Gulbarga and Bidar, of Bijapur, and occasionally other Faruqi buildings at Burhanpur. The only positive conclusion which emerges clearly is that it is not possible to define a single and unitary Faruqi or Khandesh style.

\section{Acknowledgements}

The site was visited in December 1972 by a small team consisting of Garry Martin and George Michell, architects, with myself as director. Messrs Martin and Michell measured the major buildings at the tomb site, in order to prepare plans, elevations and certain sections, and a general site plan. I took some 300 photographs, and am responsible for the textual research and for all expressions of opinion presented above. The team would like to record its gratitude firstly to Shri S.R. Rao, Superintending Archaeologist of the South-Western Circle, ASI, with whose permission, approval and, indeed, encouragement the project was undertaken. The Headmaster of the N.B.G. High School, Thalner, responded enthusiastically to a request for assistance, and not only arranged for the team's accommodation and much hospitality in Thalner but deputed his senior English master, Shri Shivaji B. Patil, as liaison officer; without the latter's constant help and interest the team's task would have been almost impossible. Our gratitude is also due to the Chairman, Secretary and Council of the V.K.S. Society of Thalner for putting a room at the team's disposal; to Shri Dingal and Shri Dongar, locally recruited as foremen; and to the villagers of Thalner for their unfailing help and courtesy to the first Europeans to visit their village in living memory. 
DOGUMENTATION 


\section{GLOSSARY OF INDIAN ARCHITECTURAL TERMS}

\begin{tabular}{|c|c|}
\hline $\bar{a} b s h \bar{a} r$ & water chute \\
\hline ämalaka & $\begin{array}{l}\text { ridged, gourd-like element crowning a dome or } \\
\text { spire }\end{array}$ \\
\hline '̄̄shūr-khāna & $\begin{array}{l}\text { building housing the alams used in Shia ceremo- } \\
\text { nies at Muharram }\end{array}$ \\
\hline aywān & arched portal \\
\hline$b \bar{a} g h$ & garden \\
\hline$b \vec{a} o l \bar{\imath}$ & step-well \\
\hline bāradarì & $\begin{array}{l}\text { free-standing pavilion associated with palaces } \\
\text { and gardens }\end{array}$ \\
\hline bhādar & citadel \\
\hline burj & fortified tower \\
\hline chabūtra & raised platform \\
\hline 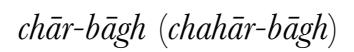 & four-square garden \\
\hline chau-chalā & $\begin{array}{l}\text { Bengali hut-shaped roof with curved ridges and } \\
\text { cornice }\end{array}$ \\
\hline chhajjā & angled overhang; eaves \\
\hline chhatrī & lit. umbrella (Sanskrit chhattra), domed pavilion \\
\hline chihil sutūn & forty-pillared hall \\
\hline chilla khāna & house of meditation \\
\hline chirāgdhān & lamp-stand \\
\hline chunam & polished plaster \\
\hline dād mahall & palace of justice \\
\hline dargāh & tomb or shrine of a saint \\
\hline darwēza & gate or doorway \\
\hline dīwāan-i '`ämm & hall of public audience \\
\hline dīwān-i khāsș & hall of private audience \\
\hline durga, durg & fort 1 \\
\hline ghāt & steps leading down to water \\
\hline guldasta & $\begin{array}{l}\text { slender, minaret-like element, rising above the } \\
\text { roof line }\end{array}$ \\
\hline gunbad & dome; domed tomb \\
\hline hammām & steam bath \\
\hline hauz & ablution pool in a mosque courtyard \\
\hline avèț & urban mansion \\
\hline
\end{tabular}




\begin{tabular}{|c|c|}
\hline$\grave{\imath} d g \bar{a} h$ & outdoor prayer area used at $\overline{\mathrm{I} d}$ \\
\hline imāmbārāa & hall used during Shia celebration during Muharram \\
\hline $\begin{array}{l}\text { jal mandir } \\
\text { jātì }\end{array}$ & $\begin{array}{l}\text { water pavilion } \\
\text { perforated screen, often of stone }\end{array}$ \\
\hline jam $\bar{a}^{`}$ at-khana & community hall \\
\hline jawāb & $\begin{array}{l}\text { "answer"; identical structure, as in the building imitating } \\
\text { the mosque in the Taj Mahall }\end{array}$ \\
\hline jharnā & water cascade \\
\hline kaksāsana & sloping back-rest in a porch or balcony \\
\hline kalaśa & pot-like finial of a dome or spire \\
\hline kangura & battlement, crenellation \\
\hline karbala & $\begin{array}{l}\text { Shia burial ground, named in remembrance of the battle } \\
\text { of Kerbala where Hussayn, the son of 'Alī, was killed }\end{array}$ \\
\hline khānqāh & $\begin{array}{l}\text { monastery, residential complex of a saint and his } \\
\text { followers }\end{array}$ \\
\hline kōtlā & citadel \\
\hline kund & $\operatorname{tank}$ \\
\hline läl qil’a & red fort \\
\hline $\operatorname{lin} w \bar{a} n$ & prayer hall of a mosque \\
\hline madrasa & theological college \\
\hline mahall & hall or chamber \\
\hline mahalla & urban quarter \\
\hline maidān & parade ground \\
\hline majlis-khāna & assembly hall \\
\hline maqbara & tomb \\
\hline mandapa & columned hall of a temple \\
\hline mandir & temple or pavilion \\
\hline manzil & palace, mansion \\
\hline maqbara & graveyard; tomb \\
\hline maqșüra & $\begin{array}{l}\text { screened area of a prayer hall of a mosque, generally at } \\
\text { mezzanine level, intended for the ruler or other promi- } \\
\text { nent figure and his entourage to pray in private }\end{array}$ \\
\hline masjid & mosque \\
\hline mazār & small wayside shrine \\
\hline merlon & ornamental battlement \\
\hline midhana & place for the call of prayer, minaret \\
\hline mihmān-khāna & guest house \\
\hline mihrāa & $\begin{array}{l}\text { niche in a prayer hall of a mosque, indicating the } \\
\text { direction of Mecca }\end{array}$ \\
\hline
\end{tabular}




\begin{tabular}{|c|c|}
\hline $\bar{a} r$ & minaret \\
\hline minbar & stepped pulpit in the prayer hall of a mosque \\
\hline$m \bar{\imath} r-i$ farsh & ornamental weight to secure a cloth covering a tomb \\
\hline muqarnas & stalactite vaulting or detail \\
\hline mușallā & $\begin{array}{l}\text { floor compartment in a mosque resembling a prayer- } \\
\text { mat }\end{array}$ \\
\hline nahr & canal \\
\hline namāzgāh & place of prayer \\
\hline naubat-khāna & drum-house, usually above a gateway \\
\hline opus sectile & inlaid stonework \\
\hline pietra dura & $\begin{array}{l}\text { technique of Italian origin of inlaying semiprecious } \\
\text { stones into marble }\end{array}$ \\
\hline qabaristān & graveyard \\
\hline qaisariyya & market \\
\hline$q \bar{a} n \bar{a} t \bar{\imath}$ & mosque a mosque consisting of a qibla wall only \\
\hline qașr & fort, palace, residence \\
\hline il'a & fort \\
\hline qibla & direction of Mecca; in India this is often due west \\
\hline rahat & Persian wheel, used to raise water from a well \\
\hline rauza & monumental tomb within an enclosure \\
\hline riwāq & side colonnades of a mosque \\
\hline $\operatorname{sar} \bar{a} \bar{\imath}$ & caravanserai \\
\hline șahn & courtyard of a mosque \\
\hline sikhara & curved temple tower \\
\hline tahkhāna & underground chamber \\
\hline takht & seat, throne \\
\hline tàl, tālàà & tank, lake \\
\hline aiwdh & gravestone \\
\hline thulth & $\begin{array}{l}\text { monumental calligraphic style, often used for Qur'ānic } \\
\text { passages }\end{array}$ \\
\hline torana & $\begin{array}{l}\text { free-standing portal in temple architecture; adopted as } \\
\text { a decorative feature in mosques and tombs }\end{array}$ \\
\hline$v \bar{a} v$ & step-well \\
\hline vihāra & Buddhist monastery \\
\hline zanāna & women's apartment \\
\hline ziyārat & tomb-shrine \\
\hline
\end{tabular}




\section{ABBREVIATIONS OF JOURNALS AND MONOGRAPHIC SERIES}

$\begin{array}{ll}\text { AARP } & \text { Art and Archaeology Research Papers } \\ \text { AB } & \text { Art Bulletin } \\ \text { AI } & \text { Ancient India } \\ \text { AR } & \text { Asiatick Researches } \\ \text { Ar A } & \text { Artibus Asiae } \\ \text { Ars I } & \text { Ars Islamica } \\ \text { AR IE } & \text { Annual Report, Indian Epigraphy } \\ \text { ARADHS } & \text { Annual Report, Archaeological Department, Hyderabad State } \\ \text { ASBC } & \text { Archaeological Survey, Bengal Circle } \\ \text { ASI } & \text { Archaeological Survey of India } \\ \text { ASIR } & \text { Archaeological Survey of India Reports } \\ \text { ASI AR } & \text { Archaeological Survey of India Annual Reports } \\ \text { ASI NIS } & \text { Archaeological Survey of India New Imperial Series } \\ \text { ASWI } & \text { Archaeological Survey of Western India } \\ \text { BDC } & \text { Bulletin of the Deccan College } \\ \text { BSOAS } & \text { Bulletin of the School of Oriental and African Studies } \\ \text { CHI } & \text { Cambridge History of India } \\ \text { EI } & \text { Epigraphia Indica } \\ \text { EI APS } & \text { Epigraphia India, Arabic and Persian Supplement } \\ \text { EIM } & \text { Eipgraphia Indo Moslemica } \\ \text { IA } & \text { Indian Antiquary } \\ \text { IC } & \text { Islamic Culture } \\ \text { IHQ } & \text { Indian Historical Quarterly } \\ \mathcal{F A} & \text { Fournal of Antiquarians } \\ \mathcal{F} A H S & \text { Fournal of the Andhra Historical Society } \\ \mathcal{F} A S B \text { (NSS) } & \text { Fournal of the Asiatic Society of Bengal (New Series) } \\ \mathcal{F A S D} & \text { Fournal of the Archaeological Society of Delhi } \\ \mathcal{F} B B R A S & \text { Fournal of the Bombay Branch of the Royal Asiatic Society } \\ \mathcal{F} B O R S & \text { Fournal of the Bihar and Orissa Research Society } \\ \mathcal{F} I A & \text { Fournal of Indian Art } \\ \mathcal{F} P H S & \text { Fournal of the Pakistan Historical Society } \\ \mathcal{F} P S I & \text { Fournal of the Photographic Society of India } \\ \mathcal{F} R A S & \text { Fournal of the Royal Asiatic Society } \\ \mathcal{F} U P H S & \text { Fournal of the United Provinces Historical Society } \\ & \end{array}$


KO Kunst des Orients

MASI Memoirs of the Archaeological Survey of India

NCHI New Cambridge History of India

OA Oriental Art, New Series

PA Pakistan Archaeology

PQ Pakistan Quarterly

TRIBA Transactions of the Royal Institute of British Architects 


\section{BIBLIOGRAPHY}

The following list has been complied from the individual bibliographies given for the different articles reproduced in this volume. A selection of monographs and reports published after John Burton-Page authored his various articles is included here so as to bring the bibliography up to date; these works are indicated by an asterisk.

\section{General Works}

\section{Islamic Architecture in India}

Ahmad Khan, Sayyid, Athar al-Sanadid, Delhi 1847, 2nd ed. Delhi 1854, later liths. Lucknow 1876 and 1900, and Cawnpore 1904.

*Alfieri, B.M., Islamic architecture of the Indian subcontinent, London 2000.

*Blair, S.S. and J.M. Bloom, The art and architecture of Islam, 1250-1800, Chapters 11 and 18, New Haven and London 1994.

Briggs, M. S., M.S., "Muslim architecture in India," in G.T. Garratt, ed., The legacy of India, Oxford 1937, 223-55.

Brown, Percy, Monuments of the Mughal period, in CHI, Cambridge 1937, iv, 523-76.

—- Indian architecture (Islamic period), Bombay n.d. (1943?).

Burton-Page, J., "A study of fortification in the Indian subcontinent from the thirteenth to the eighteenth century A.D.," BSOAS, 23 (1960), 516-22.

- "Indo-Islamic architecture: a commentary on some false assumptions," AARP, 6 (1974), 14-21.

Cole, H.H., Preservation of national monuments. Report for ... 1882-3, Calcutta 1883.

Creswell, K.A.C., A bibliography of the architecture, arts and crafts of Islam to 1st Jan. 1960, Cairo 1961, 97-191

__ * *Supplement, Fan. 1960 to Fan. 1972, Cairo 1973, 23-34.

—. *Second supplement, Jan. 1972 to Dec. 1980, Cairo 1084, 53-63.

Desai, Z.A., Indo-Islamic architecture, New Delhi 1970. , The mosques of India, New Delhi, 1971.

*Dhama, B.L., Indian architecture, Jaipur n.d.

Fergusson, J., History of Indian and eastern architecture, London 1876, revised and ed. by J. Burgess and R.P. Spiers, 2 vols., London 1910 (esp. ii, 186-335).

Goetz, H., Arte dell' India musulmana e correnti moderne, in Le civiltà dell' Oriente, Rome 1962, 4, 780-882.

Havell, E. B., Indian architecture its psychology, structure and history from the first Muhammadan invasion..., London 1913.

*Hegewald, J., Water architecture in South Asia, Leiden 2002.

Hoag, J.D., Islamic architecture, New York 1977, 280-307, 364-88.

Jairazbhoy, R.A., An outline of Islamic architecture, London 1961.

*Juneja, M., ed., Architecture in medieval India: Forms, contetxs, histories, Delhi 2001.

*Khan, A.N., Islamic architecture in South Asia: Pakistan-India-Bangladesh, Karachi 2003.

Kittoe, Markham, Illustrations of Indian architecture from the Muhammadan conquest downwards..., Calcutta 1838.

La Roche, E., Indische baukunst, II. Teil, Moscheen und Grabmaker, Munich 1921.

*Lambah, A.N. and A. Patel, eds., The architecture of the Indian Sultanates, Mumbai 2006. 
Marshall, J.H., The monuments of Muslim India, in CHI, Cambridge 1937, iii, 568-640.

*Nath, R., History of sultanate architecture, New Delhi 1978.

__, *Islamic architecture and culture in India, New Delhi 1982.

Piggott, S., Some ancient cities of India, Bombay 1945.

Quraishi, M.H., List of ancient monuments protected... in Bihar and Orissa (= ASI NS, li), Calcutta 1931.

Sharma, Y.D., "Islamic monuments," in A. Ghosh, ed., Archaeological remains: monuments and museums, XXVI International Congress of Orientalists, Delhi 1964, ii, 241-328.

*Shokoohy, M., "11th-16th centuries, Indo-Islamic architecture," in The Dictionary of Art, J. Turner, ed., London and New York 1996, xv, 337-57.

Smith, V.A., History of fine art in India and Ceylon ..., Oxford 1911, 391-420.

*Merklinger, E.S., Sultanate architecture of pre-Mughal India, New Delhi 2005.

Soundara Rajan, K.V., Islam builds in India (cultural study of Islamic architecture), Delhi 1983.

*Tadgell, C., The History of Architecture in India, London 1990.

Toy, S., The strongholds of India, London 1957.

*Volwahsen, A., Living architecture: Islamic India, London 1970.

Wheeler, Wheeler, R.E.M., Five thousand years of Pakistan, London 1950.

— , Splendours of the east, London 1965, 68-71.

Inscriptions on Islamic Monuments

*Begley, W.E., Monumental Islamic calligraphy from India, Villa Park, Illinois 1985.

Bendrey, V.S., A Study of Muslim inscriptions, Bombay 1944.

*Desai, Z.A., A Topographical list of Arabic, Persian and Urdu inscriptions of South India, New Delhi 1989. 1999

Horovitz, J., A list of the published Mohamedan inscriptions of India, EIM, 1909-10, 30-144.

Husain, M.M.A., Record of all the Quranic and non-historical epigraphs on the protected monuments in the Delhi Province, MASI, 47, Calcutta 1936.

\section{Works Dealing with Particular Regions or Periods}

\section{Delhi Sultanate}

(Ajmer, Delhi, Hansi, Irich, Koil, Meerut, Nagaur)

Aligarh gazetteer, 1902, $165 \mathrm{ff}$.

Banerji, S.K., "The Qutb Minar: its architecture and history," fUPHS, x/1 (1937), 38-58.

Beglar, J., ASI, iv, 1874, 6 ff.

Campbell, C.J., "Notes on the history and topography of the ancient cities of Delhi," in $\mathcal{F} A S B$, xxxv/1 (1866), 199-218.

Carr Stephen, The archaeology and monumental remains of Delhi, Simla etc. 1876.

Chaghatai, M.A., "Nagaur: a forgotten kingdom," BDC, ii (1941), 166-83.

Cole, H.H., The architecture of ancient Delhi, London 1872.

Cunningham, A., ASI, i, 1871 ; xi, 1880.

Digby, S., "The tomb of Bahlul Lodi," BSOAS, 38 (1975), 550-61.

Fanshawe, H.C., Delhi: Past and present, London 1902.

Führer, A., The monumental antiquities and inscriptions of the North-West provinces and Oudh (= ASI NS , ii), 1891. 
Garrick, H.B. W., "Report of a tour in the Panjab and Rajputana," in ASI, xxiii, Calcutta 1887, 13-9, 48-72, pls. V-VII.

Hillenbrand, R., "Political symbolism in early Indo-Islamic mosque architecture: the case of Ajmir," Iran, xxvi (1988), 105-18.

Joshi, M.C., Some Nagari inscriptions on the Qutb Minar, in Medieval India - a miscellany, ii, Aligarh 1972, 3-7.

Meister, M., "The two-and-a-half-day mosque," $O A$ NS, xviii (1972), 57-63.

Naqvi, S.A.A., "Sultan Ghari, Delhi," AI, iii (1947).

Page, J.A., Historical memoir on the Qutb (= MASI, 22), Calcutta 1926.

—, A guide to the Qutb, Delhi, Calcutta 1927, Delhi 1938.

—-A memoir on Kotla Firoz Shah, Delhi (= MASI, 52), Delhi, 1937.

*Peck, L., Delhi: A thousand years of building, New Delhi 2005.

Saraswati, S.K., "Art," in R.C. Majumdar, ed., History and culture of the Indian people, vi: The Delhi Sultanate, Bombay 1960, 661-739.

Sarda, H.B., Ajmer: historical and descriptive, Ajmer 1911.

Sharma, Y.D., Delhi and its neighbourhood, Delhi 1964.

Sharp, H., Delhi: its story and buildings, London 1921.

*Shokoohy, M. and N.H. Shokoohy, Hisar-i Firuza: Sultanate and early Mughal architecture in the District of Hisar, India, London 1988.

_ _ *Nagaur: Sultanate and early Mughal history and architecture of the District of Nagaur, India, London 1993.

_ * *Tughluqabad: The earliest surviving town of the Delhi Sultanate," BSOAS, 57/3 (1994), 516-50.

- *The dark gate and the dungeons: the royal escape route and more: survey of Tughluqabad, second interim report," BSOAS, 62/3 (1999), 423-61.

_, * Tughluqabad, third interim report: gates, silos, waterworks and other features, BSOAS, 66/1 (2003), 14-55.

Vogel, J.Ph., Catalogue of the Delhi museum of archaeology, Appx. ii, The sultans of Delhi and their existing monuments, Calcutta 1908.

Waddington, H., "'Adilabad: a part of the 'fourth Delhi'”, AI, i (1946), 60-76.

*Welch, A. and H. Crane, "The Tughluqs: Master builders of the Delhi Sultanate," Muqarnas, 1 (1983), 123-66.

Wetzel, F., Islamische Grabbauten in Indien aus der Zeit der Soldatenkaiser, 132-1540, Leipzig 1918.

Yamamoto, Y., M. Ara and T. Tsukinowa, Architectural remains of the Delhi sultanate period (text in Japanese), 3 vols., Tokyo 1967.

Zafar, Hasan, M., A guide to Nizamu-d Din (= MASI, 10), Calcutta 1922.

\section{Bengal}

(Gaur, Pandua)

Asher, G.B., "Inventory of key monuments," in G. Michell, ed., The Islamic heritage of Bengal, UNESCO, Paris 1984, 37-140.

*__. Islamic monuments of eastern India and Bangladesh, Leiden 1991.

Dani, A.H., Muslim architecture in Bengal, Dacca 1961.

*Hasan, P., "Sultanate mosques and continuity in Bengal architecture," Muqarnas, vi (1989): 58-74.

* , The early muslims architecture of Bangladesh: Sultans and mosques, London 2007.

Hasan, S.M., Muslim monuments of Bangladesh, Dacca 1979.

__ *Mosque architecture of pre-Mughal Bengal, Dacca 1979.

Horn, P., Muhammadan inscriptions from Bengal, in EI, ii, 1894.

Ravenshaw, J.H., Gaur: Its ruins and inscriptions, London 1878. 


\section{Uttar Pradesh}

(Etawa, Badaun, Banaras, Jaunpur, Kalpi, Kanauj, Meerut)

Blakiston, J.B., The Fami Masjïd at Badaun... MASI, 19, Calcutta, 1926.

Cunningham, ASI, xi, Calcutta 1880; ASI xxi, Calcutta 1885.

Führer, A., The monumental antiquities and inscriptions of the North-West Provinces and Oudh (= ASI NS, ii), 1891.

Führer, A. and E. Smith, The Sharqi architecture of Faunpur (= ASI NIS, xi), Calcutta 1889.

Horne, J., "Notes on the Jumma Masjid of Etawah," FASB, xxxvi/1 (1867), 74-5.

Lehmann, F., "The name and origin of the Atala Masjid, Jaunpur," IC, 52 (1978), 19-27.

*Rötzer, K., "Mosques and tombs," in G. Michell and R.P.B. Singh, eds., Banaras, the city revealed, Mumbai 2005.

Gujarat

(Ahmadabad, Bhadreswar, Bharoch, Cambay, Champaner, Dholka, Jalor, Mahmudabad)

ASI AR, 1925-6, 24-5; 1929-30, 34-5.

Bombay gazetteer, V, $318 \mathrm{ff}$.

Burgess, J., Memorandum on the antiquities at Dabhol, Ahmedabad, Than, Junagadh, Girnar and Dhank, ASWI, ii, Bombay 1875.

- Memorandum on the remains at Gumli, Gop, and in Kachh, etc., ASWI, iii, Bombay 1875.

—, Report on the antiquities of Kathiawad and Kachh..., ASI NS, ii, London 1876.

- Lists of the antiquarian remains in the Bombay Presidency..., ASWI, xi, Bombay 1885.

_- On the Muhammadan architecture of Bharoch, Cambay, Dholka, Champanir and Mahmudabad in Gujarat, ASWI, vi (= ASI NIS, xxiii), London 1896.

- The Muhammadan architecture of Ahmadabad, 2 vols., ASWI, vii and viii (= ASI NIS, xxiv, xxxiii), Calcutta 1900 and 1905.

Burgess, J. and H. Cousens, The architectural antiquities of northern Gujarat..., ASWI, ix (= ASI NIS, xxxii), London 1903.

Burton-Page, J., "Mosques and tombs," in G. Michell and S. Shah, eds., Ahmadabad (= Marg, xxxix/3), 30-119,

Chaghatai, M.A., Muslim monuments of Ahmadabad through their inscriptions, Poona 1934.

Commissariat, M.S., A History of Gujarat, 2 vols., London 1938 and Bombay 1957.

Cousens, H., Revised list of antiquarian remains in the Bombay Presidency..., (= ASI NIS, xvi), Bombay 1897.

Eastwick, B., "Champanir and Pawagadh," $I A$, ix (1880), 221-4.

Jain-Neubauer, J., The step-wells of Gujarat, Delhi 1981.

*Patil, A., Building communities in Gujarat: Architecture and society during the twelfth through fourteenth centuries, Leiden 2004.

Progress Report, ASI Western Circle, year ending March 1909, Bombay 1909, 54 ff.

*Shokoohy, M., Bhadreśvar: The oldest Islamic monuments in India, Leiden 1988.

Soundara Raja, K.V., Ahmedabad, ASI, New Delhi 1980.

\section{Malwa}

(Chanderi, Dhar, Mandu)

ASI AR, 1902-3, 303; 1903-4, 30-45.

Barnes, E., "Dhar and Mandu," FBBRAS, xxi (1904), 340-54.

_-, "Mandu and Dhar," ASI AR 1903-04, Calcutta 1906. 
Cunningham, A., ASI, ii.

Grade, M.B., Guide to Chanderi, Gwalior 1928.

Luard, C.E., Gwalior State gazetteer, i, Bombay 1908, 209-12.

— Dhar State gazetteer, Boombay 1908, 106-12.

*Nath, R., The art of Chanderi, New Delhi 1979.

Patil, D.R., Mandu, New Delhi (ASI) 1975.

Saksena, R., "Persian inscriptions in the Gwalior State," IHQ, i (1925), 653-6.

Yazdani, G., "The inscription on the tomb of 'Abdullah Shah Changal at Dhar," EIM, 1909-10, 1-5.

- Mandu, the city of joy, Oxford 1929.

Zafar Hasan, M., "The inscriptions of Dhar and Mandu," EIM, 1909-10, 6-29.

\section{Khandesh}

(Burhanpur, Thalner)

Gunningham, ASI, ix, Central Provinces, 1873-5.

\section{Berar}

(Gawligarh, Mahur, Narnala)

ASI AR, 1920-1, pl. VIIIA; and 1922-3, 56-8, pl. XXIc.

Haig, T.W., "Inscriptions of Berar," EIM 1907-8, 10-21.

Yazdani, G., "Report on the 'Adilabad district," ARADHS, 1917-8, 6-8.

—_, "Description of some of the antiquities...," FAHS (1918), 48-59.

\section{The Deccan}

(Ahmadnagar, Bidar, Golconda, Gulbarga, Hampi, Hyderabad, Kalyani, Kandahar, Mudgal, Naldurg)

ARADHS, 1916-7, 1917-8, 1918-9, 1921-4, 1924-5, 1926-6, 1924-5, 1925-6, 1934-5 and $1936-7$.

ASI AR, 1928-9, 5-11.

Bilgrami, S.A.A., Landmarks of the Deccan: A comprehensive guide to the archaeological remains of the city and suburbs of Hyderabad, Hyderabad 1927.

Burgess, J., Report on the antiquities in Bidar and Aurangabad districts, ASWI, iii, London 1878.

Cousens, H., Guide to Bijapur, Bombay 1905.

—_, Bijapur and its architectural remains, ASI NIS, xxxvii, Bombay 1916.

*Desai, Z.A., "Architecture: (i) The Bahmanis; (ii) Bahmani successor states," in History of medieval Deccan (1295-1724), H.K. Sherwani and P.M. Joshi, eds., ii, Hyderabad 1974, 227-304.

Fergusson, J., The great dome of Sultan Muhammad, TRIBA, 1st series, v (1854-5).

Fergusson, J. and Meadows Taylor, Architecture of Beejapoor, London 1866.

*Gadre, P.B., Cultural archaeology of Ahmadnagar during the Nizam Shahi period (1494-1632), Delhi 1986.

Haig, T.W., Historical landmarks of the Deccan, Allahabad 1907.

"Inscriptions at Gulbarga," EIM, 1907-8.

Longhurst, A.H., Hampi ruins described and illustrated, Madras 1917.

*Merklinger, E.S., "The Madrasa of Mahmud Gawan," KO, xi/1-2, 146-57. *Indian Islamic architecture: The Deccan, 1347-1686, Warminster 1981.

*Michell, G., The Vijayanagara courtly style: Incorporation and synthesis in the royal achitecture of southern India, 15th-17th centuries, New Delhi 1992.

*Michell, G. and M. Zebrowski, Architecture and art of the Deccan sultanates, NCHI, I.7, Cambridge 1999. 
*Naqvi, S., Qubt Shahi 'Ashur Khanas of Hyderabad City, Hyderabad 1982.

Nasim, M., Bijapur inscriptions (= MASI, 49), Delhi 1936.

Yazdani, G., "Inscriptions of the Bijapur kings...from Naldrug," EIM, 1917-8, 1-3.

—_, "The great mosque of Gulbarga," IC, ii (1928), 14-21.

—, "Notes on the antiquities of Kalyani," ARADHS, 1934-5, 19-23 and Appx. A.

— , "Notes on the survey of the Mudgal fort," ARADHS, 1935-6, pls. IXa and b.

—_, "Inscriptions from Kalyani, and Inscriptions from Mudgal," EIM, 1935-6.

— Bidar: its history and monuments, Oxford 1947.

*Yusuf, S., Antiquarian remains in Hyderabad state, Hyderabad 1953.

The North

(Gilgit, Srinagar, Swat Valley)

Burton-Page, J., "Muslim graves of the 'lesser tradition': Gilgit, Punial, Swat, Yusufzai," JRAS (1986), 248-54.

*Mangat-Rae, M., "Wooden mosques of Kashmir," OA NS, xiii (1967), 263-70.

Nicholls, W.H., "Muhammadan architecture in Kashmir," ASI AR, 1906-7, Calcutta 1909, 161-70.

\section{Punjab}

(Multan, Ucch)

Burton-Page, J., "The tomb of Rukn-i Alam," in Wheeler, R.M., ed., Splendours of the east, London 1965, 72-81.

Feroze, S., "Uch the ancient," PQ, v/1 (1955), 22-6.

*Khan, A.N., Islamic architecture of Pakistan: An analytical exposition, Islamabad 1990.

\section{Sindh and Baluchistan}

(Bhambor, Makli, Thatta)

Ashfaque, S.M., "The grand mosque of Banbhore," PA, vi/1 (1969), 182-209.

Cousens, H., The antiquities of Sind, Calcutta 1929, repr. Karachi 1975, $48 \mathrm{ff}$.

Ghafur, M.A., Muslim architecture in Sind area, Karachi 1961.

Idris Siddiqi, M., Thatta, Karachi 1958.

*Khan, A.N., Studies in Islamic archaeology of Pakistan, Lahore 1997.

*Khan, F.A., Bhanbore: A preliminary report of recent archaeological excavations, Karachi 1963.

*Nadiem, I.S., Makli, the necropolis at Thatta, Lahore 2000.

Zajadacz-Hastenrath, S., Chaukhandigraber: Studien zur Grabkunst in Sind und Baluchistan, Wiesbaden 1978.

\section{The Suri Interregnum}

(Delhi, Sasaram, Narnaul)

Ahmad, Q., Corpus of Arabic and Persian inscriptions of Bihar, Patna 1973.

*Asher, C.B., "The mausoleum of Sher Shah Suri," Ar A, xxxix, 3/4 (1977), 27398.

_ ( * "The Qila'-i Kuhna mosque: A visual symbol of royal aspirations," Chhavi, 2 (1981): 212-7.

ASI AR, 1922-3, 34-41, xxii.

Brown, P., "The influence of Sher Shah Sur on the Islamic architecture of India," in Proc. 3rd Ind. Hist. Cong., 1939, 636-46 (also in Bengal past and present, lviii, 1940, 57-63).

Cunningham, A., ASI, xi, 1880, 132-9. 
Goetz, H., "Sher Shah's Mausoleum at Sasaram," Ars I, v/i (1938), 97-9.

Quraishi, M.H., List of ancient monuments ... in Bihar and Orissa, ASI NIS, li, Calcutta 1931, 54-66, 139-41, 146-91, 197-202, 207-19.

Wetzel, F., Islamische Grabbauten in Indien in der Zeit der Soldatenkaiser, Leipzig 1918, 92-105, plates 272-334.

Yazdani, G., "Narnaul and its buildings," fASB NS, iii (1907), 581-6, 639-44.

\section{The Mughal Period}

(Agra, Aurangabad, Delhi, Fatehpur Sikri, Lahore, Maner, Mathura)

Ahmad, H.S., "Maner and its historical remains," in Procs. and Trans. of 6th All-India Oriental Conference, Patna 1933, 123-41.

*Asher, C.B., Architecture of Mughal India, NCHI, I.4, Cambridge 1992.

_ , *16th-19th centuries, i) Mughal," in The Dictionary of Art, J. Turner, ed., London and New York 1996, xv, 359-74, 378,80.

ASI AR, 1902-3, pl. xii; 1903-4, 25-7, pls. xii-xiii; 1904-5, 20-22, p. iv;

ASI NIS, xxii, 6.

Annual Report, Arch. Surv. Panjab and U.P., 1904, 75-8;

Bakhsh, N., "Historical notes on the Lahore fort," ASI AR, 1902-3, $218 \mathrm{ff}$.

—, "The Agra fort and its buildings," ASI AR, 1903-4, $164 \mathrm{ff}$.

Beglar, J.D. and A.C.L. Carlleyle, ASI, iv, 1874.

*Begley, W., "Amanat Khan and the calligraphy on the Taj Mahal," KO, 12 (1978-9), 5-39.

- * "The myth of the Taj Mahal and a new theory of its symbolic meaning," $A B, 6$ (1979): 7-37.

*Begley, W. and Z.A. Desai, The Taj Mahall: the illumined tomb, Seattle and London, 1989.

*Brand, M. and G.D. Lowry, eds., Fatehpur-Sikri: A sourcebook, Cambridge Mass., 1985.

Bukhari, Y.K., "Inscriptions from Maner," EI APS, 1951 and 1952 (1956), 13-24.

- "The mosque architecture of the Mughals," Indo-Iranica, ix/2 (1956), 67-75.

Burton-Page, J., "Lahore fort," "Wazir Khan's mosque, Lahore," "The Red Fort, Delhi," "Fatehpur Sikri," and "Taj Mahal, Agra," in R.E. Mortimer Wheeler, ed., Splendours of the east, London 1965, 82-93, 94-101, 130-41, 142-53, 154-65,

Bussagli, M., Il Taj mahall, Florence 1965.

Chaghtai, M.A., The Badshahi Masïd, history and architecture, Lahore 1972.

- The Wazir Khan mosque, Lahore 1975.

Crowe, S., S. Haywood and P. Jellicoe, The gardens of Mughul India: a history and guide, London 1972.

Growse, F.S., Mathura: a district memoir, Benares 1882, and subsequent reprints.

Hankin, E.H., The drawing of geometric patterns in Saracenic art, MASI, 15, 1925.

Hasan, Z., Mosque of Shaikh 'Abdu-n-Nabi, MASI, 9, Calcutta 1921.

_- "Moti Masjid or the Pearl Mosque in the Lahore Fort," in Proceedings of the Pakistan History Conference, 2nd session, Lahore 1952, 8-16.

Havell, E.B., A handbook to Agra, the Taj, Sikandra, Fatehpur Sikri..., Calcutta 1924.

Hussain, M.A., Agra fort, New Delhi 1956.

*Hussain, M.A., A. Rehman and J.L. Wescoat Jr., eds., The Mughal garden: Interpretation, conservation and implications, Lahore 1996.

Jairazbhoy, R.A., "Early gardens of the Mughals," OA NS, iv/2 (1958), 68-75.

Khan, A.R., Maryam Zamani mosque, Lahore-Karachi 1972.

*Khan, M.W.U., Lahore and its important monuments, Karachi 1961.

Kipling, J.L., "Mosque of Wazir Khan at Lahore," FIA, ii/19 (1887), 17-8.

*Koch, E., Mughal architecture: An outline of its history and development (1526-1858), Munich 1991. 
*Mughal art and imperial ideology: Collected studies, New Delhi 2001.

, *The complete Taj Mahal and the riverfront gardens of Agra, London 2006.

*Lowry, G.D., "Humayun's tomb: Form, function and meaning in early Mughal architecture," Muqarnas, 4 (1987), 133-48.

Naqqvi, S.A.A., Humayun's tomb and adjacent buildings, Delhi 1947.

Nath, R., The immortal Taj Mahal: the evolution of the tomb in Mughal architecture, Bombay 1972 .

—_, *History of decorative art in Mughal architecture, Delhi 1976.

—. Agra and its monumental glory, Bombay 1977.

, * History of Mughal architecture, 4 vols., New Delhi 1982-2005.

Nicholls, W.H., Jahangir's tomb at Shahdara, ASI AR, 1906-7, $12 \mathrm{ff}$.

- Mughal gardens of Kashmir, ASI AR, 1906-7, $161 \mathrm{ff}$.

*Petruccioli, A., La citta' del sole e delle acque: Fathpur Sikri, Rome 1988.

Rizvi, A.A. and V.J.A. Flynn, Fathpur-Sikri, Bombay 1975.

Sanderson, G., A guide to the buildings and gardens, Delhi Fort, Delhi 1937.

Smith, E.W., Mughal architecture of Fathpur-Sikri, 4 vols., ASI NIS, xviii, Allahabad $1894-7$

—-, Moghul colour decoration of Agra, ASI NIS, 30, Allahabad 1901.

- Akbar's tomb, Sikandra near Agra, described and illustrated, ASI NIS, xxv, Allahabad 1909.

Vogel, J.Ph., Tile mosaics of the Lahore fort, ASI NIS, xli, Calcutta 1920.

Zafar Hasan, M., Mosque of Shaikh 'Abdu-n Nabi (= MASI, 9), Calcutta 1921.

Zahiruddin, S., History and antiquities of Manair, Bankipore 1905. 


\section{INDEX OF SITES}

Adalaj, 66

Agra, 10, 29, 30, 31-32, 38, 49, 53, 54, $56,59,60,61,63,64,70,73,74,75$, 96, 106, 120; Figs. 57-60, 62

Ahmadabad, 14-17, 48, 52, 56, 61, 62, 66, 79-98, 112; Figs. 20-25, 28, 29

Ahmadnagar, 20, 106, 114, 137, 166, 167; Figs. 45, 46

Ajmer, 4, 5, 32, 52, 61, 65, 82, 123, 169; Fig. 2

Aland, 53

Allahabad, 29

Amber, 33

Ashtur, see Bidar

Asirgarh, 18, 19

Aurangabad, 32, 54, 63, 120; Fig. 63

Badaun, 5, 54, 155

Bagerhat, 12

Bagha, Fig. 17

Banaras, 13, 32, 45, 48, 54, 152

Bankapur, 108, 163

Barnawa, 163

Bayana, 5, 6, 51, 169

Bhadreshwar, 43

Bhambor, 4

Bharoch, 4, 6, 14, 80, 98-99

Bhilsa, 6

Bhopal, 83

Bidar, 19-21, 22, 49, 51, 52, 63, 70-71, 99-104, 116, 136, 140, 142, 154, 167, 174, 176; Figs. 38-40

Bihar Sharif, 37

Bijapur, 4, 19, 21-22, 23, 35, 37, 45, 49, $52,53,54,56,57,59,63,70,71,72$, 100, 104, 106-111, 138, 139, 141, 142, 146, 154, 164, 166, 167, 176; Figs. 41-44

Burhanpur, 18, 19, 46, 51, 170, 175

Cambay, 4, 6, 14, 52, 80-81; Figs. 18, 19

Champaner, 16, 17, 19, 86, 89, 93, $111-112$

Chanderi, 18, 30, 49, 54, 56, 112-113, 148; Fig. 33

Chandragiri, 33, 142
Chaukhandi, see Thatta

Chikalda, 18, 19

Chittaur, 112

Chota Pandua, 12, 47, 51,

Daulatabad, 4, 6-7, 20, 51, 52, 69, 71, 113-116, 118, 154, 163; Fig. 35

Delhi, 4-6, 7-10, 11, 12, 14, 16, 17, 19, 27, 28-29, 30, 31, 32-33, 35, 36, $37,43,44,45,46,47,49,50,51,52$, 54-55, 56, 57, 60, 61, 62, 63, 64, 65, $66,67,68-69,70,72-73,74,75,81$, 82, 87, 91, 97, 104, 107, 112, 114, $116-132,133,139,141,143,144$, $148,150,151,153,155,161,163$, 165, 169, 170, 174; Figs. 1, 3-9, 51, $52,54,61$

Devagiri, see Daulatabad

Dhaka, 54

Dhar, 4, 17, 48, 82, 133-134, 148; Fig. 30

Dharwar, 108

Dholka, 14, 15, 52, 80, 81, 87

Dig, 64

Elichpur, 20, 71, 114, 137

Etawa, 13, 48, 134-136, 150, 152

Fatehpur Sikri, 17, 18, 25, 28, 29-30, 39, 45, 46, 49, 51, 59, 60, 65, 73, 75, 94; Figs. 55, 56

Fathabad, 8

Gaur, 4, 12, 51; Fig. 16

Gawilgarh, 20, 71, 136-138

Ghazni, 50, 122, 133, 134, 142, 158, 160

Goa, 106

Gogi, 49

Golkonda, 22-23, 37, 53, 57, 71, 72, 104, 106, 145, 164, 166, 167, 168; Figs. 47, 48

Gulbarga, 7, 19-20, 22, 45, 49, 53, 55, 60, 70, 138-140, 142, 163, 176; Figs. 36,37

Gurgaon, 169

Gwalior, 30, 60, 72; Fig. 27 
Hampi, 33, 140-142, 163, 164, 167

Hansi, 5, 142-144

Hazrat Pandua, 12, 47; Fig. 15

Hisar, 8

Holkonda, 139

Hyderabad, 22, 37, 49, 53, 107, 145-148, 154

Irich, 8, 47

Jahanpanah, see Delhi

Jaipur, 33, 60

Jalor, 4, 6, 148-149

Jam, 50

Jaunpur, 4, 8, 13, 30, 37, 38, 43, 44, 48, $64,70,92,104,135,143,149-152$, 153; Figs. 12, 13

Junagadh, 33, 86, 96

Kalinjar, 155

Kalpi, 10, 153-154

Kalyani, 71-72, 154

Kandahar, 71, 156-157

Kanauj, 13, 135, 150, 152, 153, 154-156

Khambayat, see Cambay

Khargird, 102

Khuldabad, 55, 58

Kirman, 50

Koyl, 51, 150

Lahore, 11, 29, 30, 31, 32, 36, 53, 63, 70, 73-74, 83, 116

Lakhnauti, see Gaur

Lucknow, 33

Mahmudabad, 16, 86, 93; Fig. 26

Mahur, 157-158

Malikpur, see Delhi

Mandu, 4, 17-18, 38, 48-49, 83, 112, 113, 133, 148, 173; Figs. 31, 32

Mandva, 66

Maner, 105, 158-160

Mangrol, 14

Mathura, 32, 53, 160-161

Meerut, 161-163

Mehrauli, see Delhi

Monghyr, 104, 105

Mudgal, 71, 163-164, 167

Multan, 6, 11, 36, 60, 124; Fig. 10

Murshidabad, 54

Mysore, 37

Nagaur, 5, 143, 165-166

Naldurg, 7 1, 72, 166-168
Narnala, 20, 71, 137, 168-169

Narnaul, 28, 60, 62, 169-170

Old Malda, 51

Palamav, 105

Pandua, 4, 12, Fig. 14

Panhala, 71

Panipat, 27

Parenda, 71

Patan, 4, 6, 13-14, 80, 99

Petlad, 14

Raichur, 51, 52, 71, 163, 167

Rajmahal, 105

Rohtas, 28

Rohtasgarh, 28, 105

Sardhana, 163

Sarkhej, see Ahmadabad

Sambhal, 27

Sasaram, 10, 27-28, 60, 62, 75, 105; Fig. 53

Satara, 107

Shahanur, 108

Shahdrug, 108

Shajahanabad, see Delhi

Shaykhupura, 51, 62

Sholapur, 167

Siddhpur, 6

Sikandra, see Agra

Siri, see Delhi

Srinagar, 23-24, 63; Figs. 49, 50

Srirangapattana, 33, 47-48, 53

Thalner, 18-19, 60, 170-176; Fig. 34

Thatta, 24-25, 58, 59, 96

Tijara, 9

Tribeni, 4, 12

Tughluqabad, see Delhi

Ucch, 11, 60; Fig. 11

Udaipur, 60, 61, 63-64

Ujjayn, 148

Varanasi, see Banaras

Vatva, see Ahmadabad

Vijayanagara, see Hampi

Vrindaban, 160

Warangal, 4, 23, 71, 99, 112, 163

Wazirabad, see Delhi

Zafarabad, 152 